\title{
LAP SPLICE DEVELOPMENT LENGTH OF REBAR IN STABILIZED HOLLOW INTERLOCKING COMPRESSED EARTH BLOCKS
}

\author{
A Thesis \\ presented to \\ the Faculty of California Polytechnic State University, \\ San Luis Obispo
}

\author{
In Partial Fulfillment \\ of the Requirements for the Degree \\ Master of Science in Civil and Environmental Engineering
}

by

Thomas Saxon Bowdey

December 2016 
(C) 2016

Thomas Saxon Bowdey

ALL RIGHTS RESERVED 
COMMITTEE MEMBERSHIP

TITLE: $\quad$ Lap Splice Development Length of Rebar in Stabilized Hollow Interlocking Compressed Earth Blocks

AUTHOR: $\quad$ Thomas Saxon Bowdey

DATE SUBMITTED: $\quad$ December 2016

COMMITTEE CHAIR: $\quad$ Daniel C. Jansen, Ph.D.

Professor of Civil and Environmental Engineering

COMMITTEE MEMBER: Bing Qu, Ph.D.

Associate Professor of Civil and Environmental

Engineering

COMMITTEE MEMBER: Peter T. Laursen, Ph.D.

Associate Professor of Architecture and

Environmental Design 


\begin{abstract}
Lap Splice Development Length of Rebar in Stabilized Hollow Interlocking Compressed Earth Blocks

Thomas Saxon Bowdey
\end{abstract}

This thesis investigates the tensile performance of unconfined lap splices in specimens constructed from interlocking compressed earth block (ICEB) units. All lap splice specimens were constructed from hollow ICEB half units with one side grouting channel. ICEB units used in this research were exclusively produced from the Soeng Thai Model BP6 block press. The BP6 block press is currently manufactured in Thailand under the guidance and direction of the Center of Vocational Building Technologies (CVBT). All ICEB units and grout constructed for this research were created from mix proportions of soil, sand, cement, and water. Rebar bar sizes were restricted to M10 (\#3) and M13 (\#4) for all lap splice specimens due to the limited area of the hollow 2-inch diameter rebar cavity of the ICEB unit. The limited size and strength of the ICEB units also made the use of larger bar diameters impractical. Three ICEB unit types of varying strengths (3.78 MPa, 7.81 MPa, and 11.38 MPa) and three grout types of varying strengths (1.35 MPa, 7.47 MPa, and 15.50 MPa) were developed and used to construct all specimens. The measured ICEB lap splice specimen strengths were compared against the predicted strength calculated from the Masonry Standards Joint Committee (MSJC). Findings suggested that the MSJC design equation did not adequately predict the lap splice strength of specimens, particularly for specimens constructed from weaker materials. The measured ICEB lap splice results were used to create a new ICEB lap splice design equation. This paper also investigates the compressive performance of fully grouted ICEB prisms constructed from the range of ICEB unit and grout strengths stated above. Findings suggested that the compressive strength of fully grouted ICEB prisms were exclusively controlled by the compressive strength of the ICEB units used to construct the prism. The strength of the grout had no discernable effect on the strength of the fully grouted prism. A design equation was proposed to calculate prism strengths based on measured strength results of ICEB units.

Keywords: Lap Splice, Interlocking Compressed Earth Block, ICEB, CEB, Prism, Grout 


\section{ACKNOWLEDGMENTS}

This research would not have been possible without the assistance and guidance of several individuals. I would like to express my deepest gratitude to my thesis advisor, Professor Daniel Jansen, for his patience, expertise, and unwavering commitment to excellence throughout the course of this research. I would also like to thank Professors Bing Qu and Peter Laursen for their time in supporting and reviewing this research.

I am indebted to my fellow graduate students, Tadei Shayo and Nick Kennedy, who provided countless hours of labor in the creation of ICEB units, the grouting of specimens, and lab testing. I am eternally grateful for your help.

To my esteemed colleagues, Osmar Rodriguez, Anthony Trigovcich, and Mason Escherich, who provided levity and camaraderie throughout our tenure at Cal Poly, I am grateful for our friendship.

I would also like to thank my family, Bradley, Deborah, Rebecca, and Aimee Bowdey, for their continued support throughout all my academic and professional pursuits. You all mean everything to me.

Finally, thank you to my wonderful girlfriend, Ashley, who witnessed many long days during the completion of this research. I could not have finished this research without your encouragement. I am lucky to have you in my life.

And to you, the reader, who may have picked up this paper to continue to investigate and advance this promising building technology, I wish you best of luck in your research. 
TABLE OF CONTENTS

Page

LIST OF TABLES...................................................................

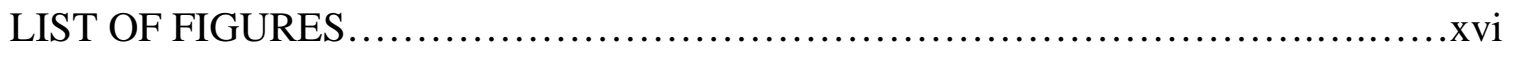

CHAPTER

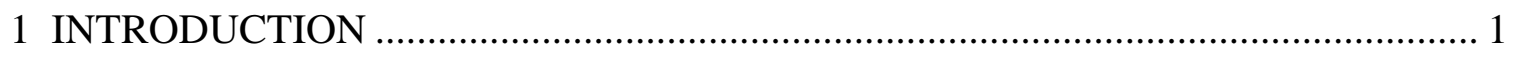

1.1 IMPROVEMENTS IN COMPRESSED EARTH TECHNOLOGY ........................ 3

1.2 RHINO INTERLOCKING COMPRESSED EARTH BLOCKS............................. 5

1.3 RHINO INTERLOCKING COMPRESSED EARTH BLOCK PRESS .................. 5

1.4 LAP SPLICE APPLICATIONS IN ICEB STRUCTURES …………………….... 7

1.5 RESEARCH PURPOSE AND SIGNIFICANCE ……………………………...... 7

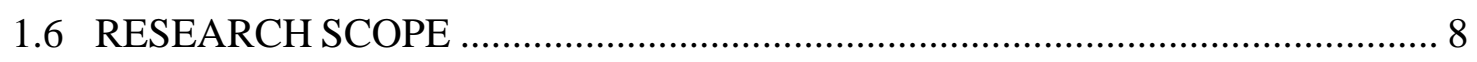

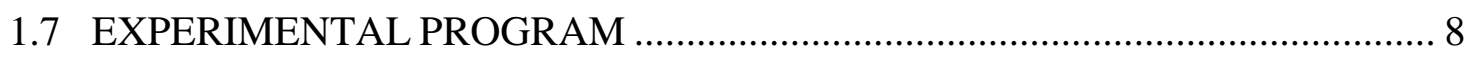

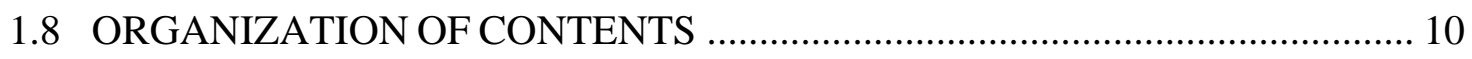

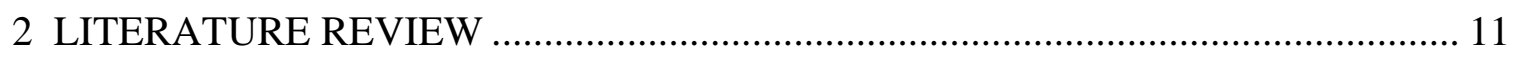

2.1 PREVIOUS COMPLETED ICEB RESEARCH AT CAL POLY ........................ 11

2.1.1 IN PLANE CYCLIC SHEAR PERFORMANCE OF INTERLOCKING

COMPRESSED EARTH BLOCK WALLS. DAVID BLAND. 2011....................... 11

2.1.2 FLEXURAL BEHAVIOR OF INTERLOCKING COMPRESSED

EARTH BLOCK SHEAR WALLS SUBJECTED TO IN-PLANE

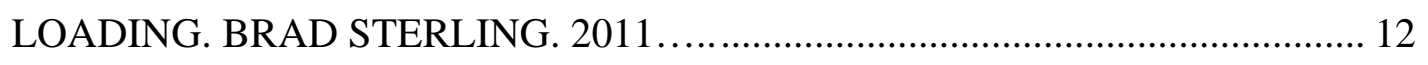


2.1.3 INVESTIGATION OF OUT-OF-PLANE PROPERTIES OF INTERLOCKING COMPRESSED EARTH BLOCK WALLS. NICK

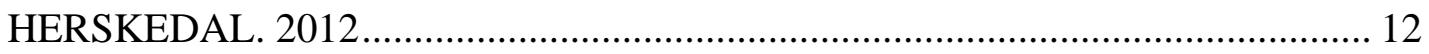

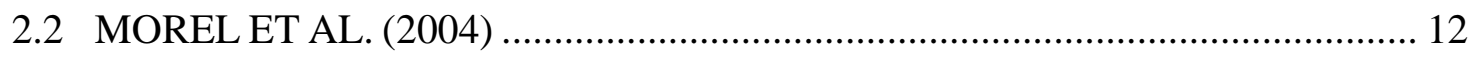

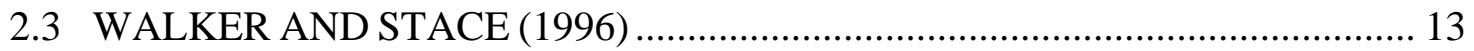

2.4 MSJC LAP SPLICE EQUATION....................................................................... 14

2.4.1 ORIGINS OF MSJC LAP SPLICE EQUATION ........................................ 15

2.5 HAMMONS ET AL. (1994) ……………………......................................... 16

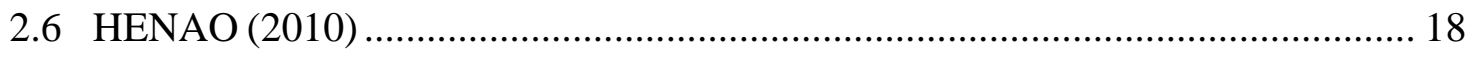

2.7 CANBAY AND FROSCH (2005) .............................................................. 19

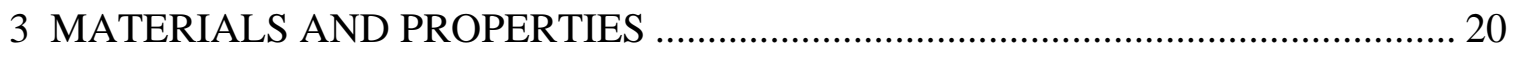

3.1 INTERLOCKING COMPRESSED EARTH BLOCK CONSTRUCTION........... 20

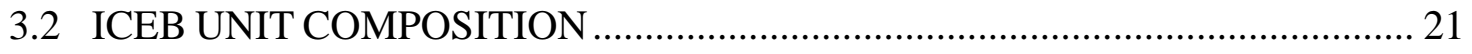

3.2.1 SOIL PROPERTIES ......................................................................... 21

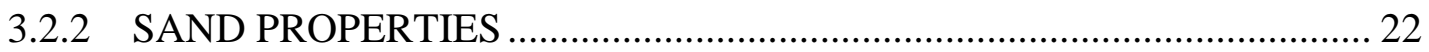

3.2.3 CEMENT PROPERTIES..................................................................... 23

3.3 MATERIALS PREPARATION ……………………................................... 23

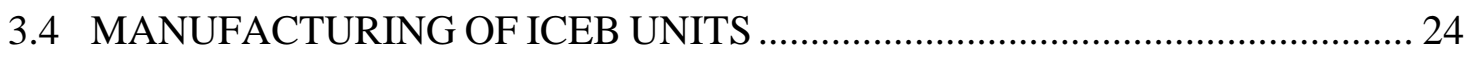

3.4.1 ICEB UNIT MATERIAL PROPORTIONS …………………………..... 24

3.4.2 MATERIAL MIXING ...................................................................... 25

3.4.3 OPTIMUM WATER CONTENT ............................................................ 26

3.4.4 ICEB MIX WATER CONTENT .......................................................... 27 
3.4.5 PRESSING AND EXTRACTION OF ICEB UNITS ................................ 27

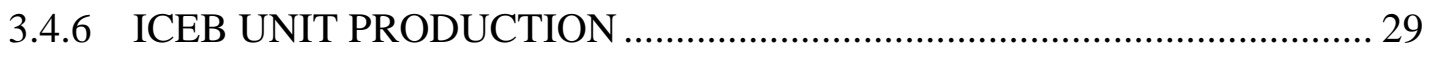

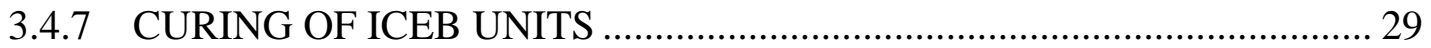

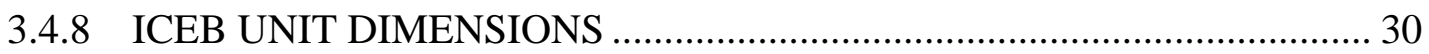

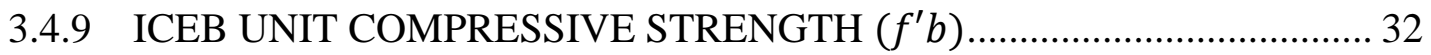

3.4.10 AVERAGE ICEB UNIT COMPRESSIVE STRENGTH $\left(f^{\prime} b\right)$

AND QUALITY ASSURANCE OF ICEB BATCHES ........................................ 33

3.4.11 BLAND (2011) ICEB UNIT STRENGTH $\left(f^{\prime} b\right)$ COMPARISON.......... 35

3.4.12 COMPRESSIVE ICEB UNIT STRENGTH $\left(f^{\prime} b s\right)$ VS.

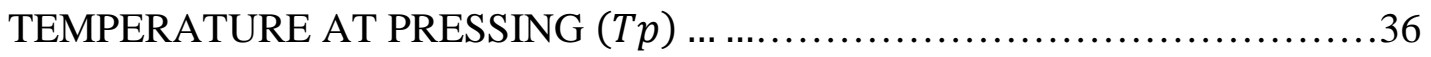

3.4.13 COMPRESSIVE ICEB UNIT STRENGTH $\left(f^{\prime} b s\right)$ VS.

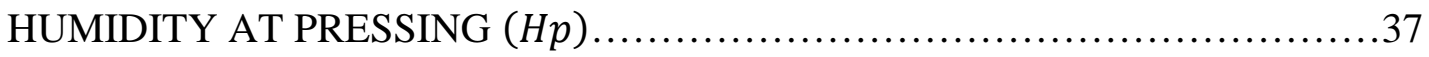

3.5 GROUT PREPARATION AND SAMPLING METHODOLOGY ..................... 38

3.5.1 GROUT VS. NON-POROUS GROUT …............................................... 38

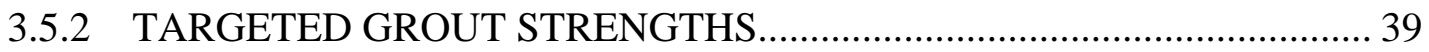

3.5.3 GROUTING STAGES OF GROUT SPECIMENS, PRISMS, AND

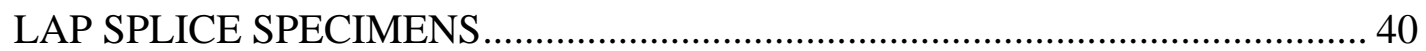

3.5.4 GROUT TESTING MATRIX AND SPECIMEN NAME

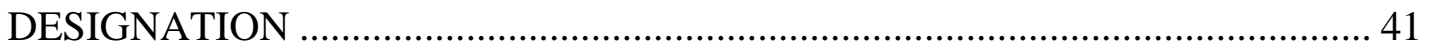

3.5.5 NON-POROUS GROUT TESTING MATRIX AND SPECIMEN

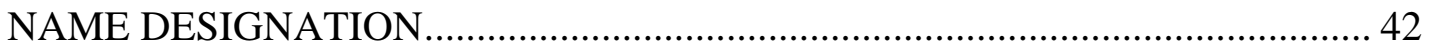

3.5.6 GROUT SULFUR CAPPING ............................................................ 43 
3.5.7 GROUT TESTING

3.5.8 NON-POROUS GROUT AND GROUT SPECIMEN

ASPECT RATIO AND DIMENSIONS ……………………................................ 43

3.5.9 NON-POROUS GROUT WATER LOSS ................................................... 44

3.5.10 GROUT SPECIMEN INSTRUMENTATION .......................................... 45

3.5.11 TEST MACHINE AND SPECIMEN LOADING RATE ......................... 45

3.5.12 GROUT VS. NON-POROUS GROUT STRENGTH ………….............. 46

3.5.13 GROUT COMPRESSIVE STRENGTH $\left(f^{\prime} g\right)$ VS.

SOIL CONTENT, CEMENT CONTENT ............................................................ 47

3.5.14 GROUT STRENGTH $\left(f^{\prime} g\right)$ VS. ICEB UNIT CURE TYPE ................... 47

3.5.15 NON-POROUS COMPRESSIVE GROUT

STRENGTH $\left(f^{\prime} p g\right)$ VS. GROUTING STAGE (I, II, III) .......................48

3.6 AVERAGE CURING TEMPERATURE AND HUMIDITY ................................ 49

3.7 SPECIFIED COMPRESSIVE STRENGTH OF MASONRY $\left(\mathrm{F}^{\prime} \mathrm{M}\right)$................... 49

3.7.1 ICEB PRISM CONSTRUCTION............................................................ 49

3.7.2 ICEB PRISM TESTING MATRIX ……………………............................ 50

3.7.3 PRISM HYDROSTONE CAPPING ……………….................................. 51

3.7.4 AVERAGE PRISM DIMENSIONS ............................................................ 52

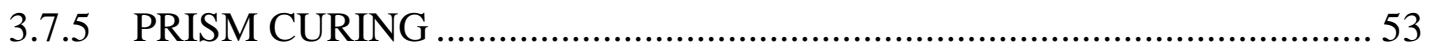

3.7.6 PRISM INSTRUMENTATION AND TESTING ….................................... 54

3.7.7 TYPICAL PRISM CONE FRACTURE FAILURE ....................................... 55

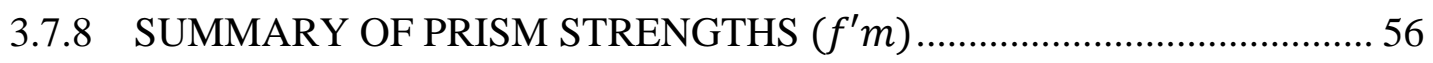


3.7.9 BLAND (2011) AND HERSKEDAL (2012) VS TESTED

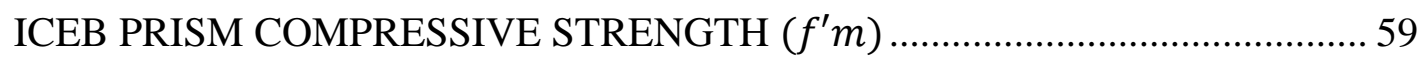

3.7.10 PRISM COMPRESSIVE STRENGTH $\left(f^{\prime} m\right)$ VS.

ICEB BATCH COMPRESSIVE STRENGTH $\left(f^{\prime} b s\right) \ldots \ldots \ldots \ldots \ldots \ldots \ldots \ldots \ldots \ldots . . . . . . . . . \ldots 1$

3.7.11 ICEB PRISM PREDICTION EQUATION ANALYSIS .......................... 63

3.7.12 PRISM PREDICTION EQUATION SUMMARY …………………....... 65

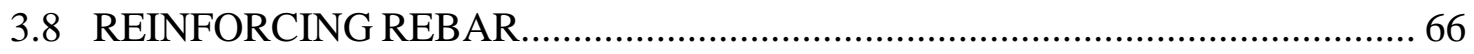

3.8.1 MAXIMUM AREA OF REINFORCEMENT REBAR PER MSJC.............. 68

4 ICEB LAP SPLICE CONSTRUCTION AND TEST SET UP ..................................... 69

4.1 PRELIMINARY LAP SPLICE THESIS RESEARCH......................................... 69

4.2 ICEB LAP SPLICE TESTING MATRIX AND SPECIMEN NAME

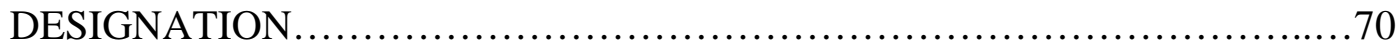

4.3 CONSTRUCTION OF ICEB LAP SPLICE SPECIMENS …………………........ 72

4.4 GROUTING OF REBAR LAP SPLICE SPECIMENS …………....................... 73

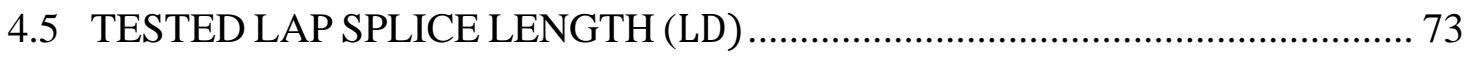

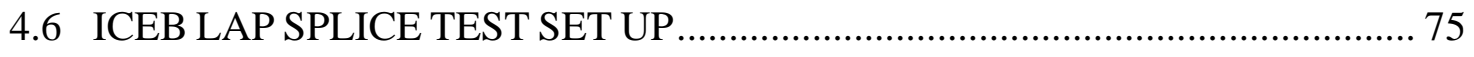

4.7 MODIFICATION OF REBAR COUPLERS ..................................................... 76

4.7.1 INSTALLATION OF LAP SPLICE SPECIMENS ..................................... 78

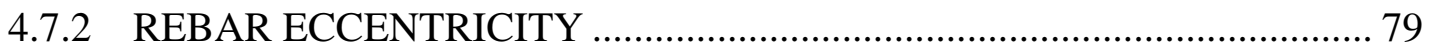

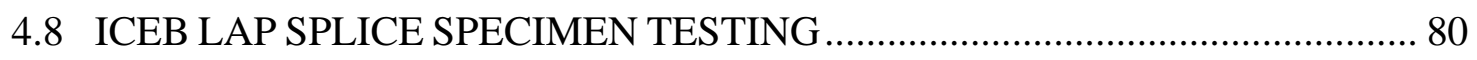

4.9 TYPICAL FAILURE MODES OF LAP SPLICE SPECIMENS ............................ 80

4.9.1 SPLITTING OF GROUT AND MASONRY FAILURE ............................... 81 
4.9.2 PULL-OUT OF REINFORCEMENT BAR ............................................... 84

4.10 YIELDING OF LAP SPLICE REINFORCING REBAR ............................. 85

5 LAP SPLICE EXPERIMENTAL RESULTS AND ANALYSIS .............................. 92

5.1 MSJC LAP SPLICE STRENGTH PREDICTION EQUATION

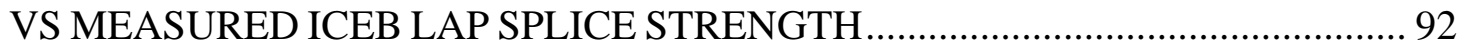

5.2 MEASURED ICEB LAP SPLICE STRENGTH (TM) VS. ICEB UNIT

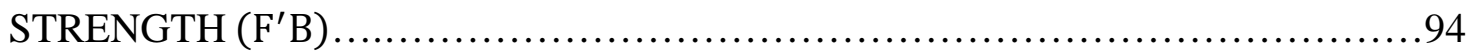

5.3 MEASURED ICEB LAP SPLICE STRENGTH (TM) VS.

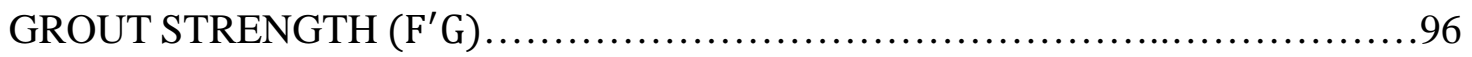

5.4 MEASURED ICEB LAP SPLICE LENGTH (LS) VS.

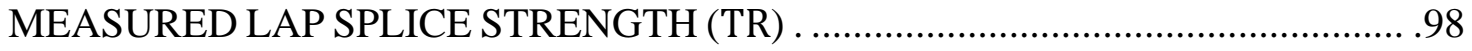

5.5 MEASURED ICEB LAP SPLICE STRENGTH (TM) VS. PRISM

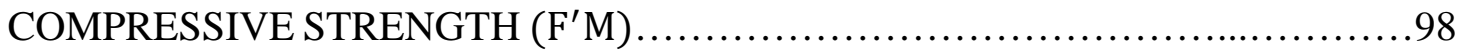

5.6 ICEB LAP SPLICE EQUATION RECOMMENDATION ….......................... 100

5.6.1 LAP SPLICE PREDICTION EQUATION 5.1 ................................... 101

5.6.2 LAP SPLICE PREDICTION EQUATION 5.2 .................................... 103

5.6.3 LAP SPLICE STRENGTH PREDICATION

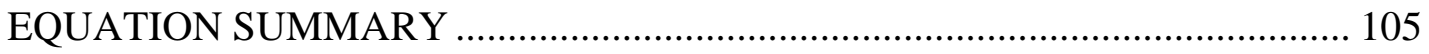

5.7 ICEB LAP SPLICE LENGTH PREDICTION EQUATION .......................... 105

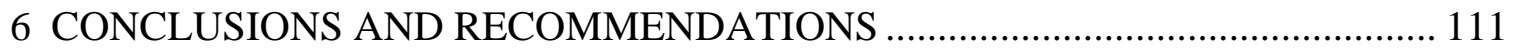

6.1 POTENTIAL FOR FUTURE WORK....................................................... 113 
WORKS CITED

\section{APPENDICES}

APPENDIX A: NOTATION SUMMARY .............................................116

APPENDIX B: LAP SPLICE SPECIMEN DATA......................................117

APPENDIX C: GROUT SPECIMEN DATA SUMMARY..........................128 


\section{LIST OF TABLES}

Page

TABLE 1: Soeng Thai ICEB Unit Types AND Descriptions ...............................................6

TABLE 2: SOIL CHARACTERISTICS PER ASTM D4318-05 FROM BLAND (2011) ...................21

Table 3: Weak, Medium, and Strong ICEB Unit Mix Proportions ............................24

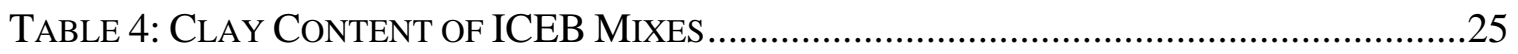

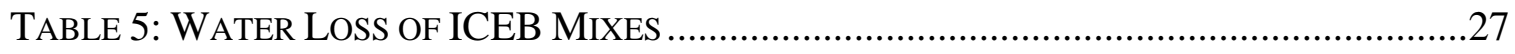

TABle 6: AVERAge ICEB Unit Dimensions AND Weights .................................................31

TABLe 7: ICEB Unit Compressive Batch StRength (F'Bs) AND AVERAge COMPRESSIVE STRENGTH OF ICEB UNITS (F'B) .......................................................34

TABLE 8: Bland (2011) vs. Tested ICEB Unit Compressive Strength (F'B) B..............35

TABLE 9: GRout BATCH Mix PROPORTIONS .................................................................40

TABLE 10: GRouting SCHEDULE AND SPECIMEN NAMES ..................................................42

TABLE 11: Non PoROUS GROUTING SCHEdULE ............................................................42

TABLE 12: Non- PoRous Grout SPECIMEN DiMENSIONS ..................................................43

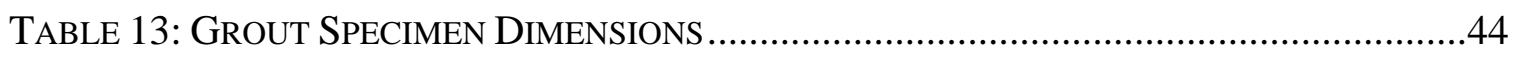

TABLE 14: WATER LOSS OF NON-POROUS GROUT ..............................................................44

Table 15: Average Grout And Non-Porous Grout Compressive Strength.............46

TABle 16: Grout Strength (F'G) vs. ICEB Unit Cast Type (W, M, S) ..........................47

TABLe 17: Non-Porous Grout Strength (F'PG) Vs. Grouting Stage (I, II, III) ..........48

Table 18: Non-Porous Grout Strength (F'G) vs. Grouting Stage (I, III).................48

TABle 19: AVERAge CuRing TemPerature AND Humidity .............................................49

Table 20: Prism Testing MatriX and Specimen Name Designation.............................50 
TABLE 21: FulLy GROUTED PRISM DiMENSIONS ......................................................52

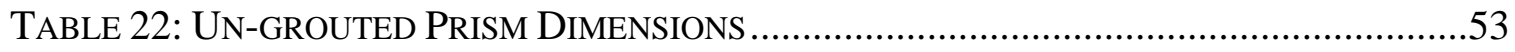

TABle 23: Summary of Fully Grouted Prism Compressive Strengths ( $\mathrm{F}^{\prime} \mathrm{M}$ ) Vs. Grout Compressive STRENGTH $\left(\mathrm{F}^{\prime} \mathrm{G}\right)$ AND ICEB Unit COMPRESSIVE

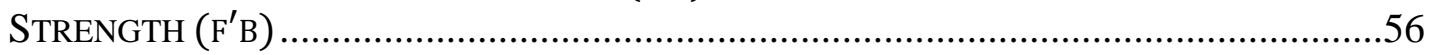

TABle 24: Fully Grouted Prism Strength ( $\left.\mathrm{F}^{\prime} \mathrm{M}\right)$ VS. Un-Grouted Prism

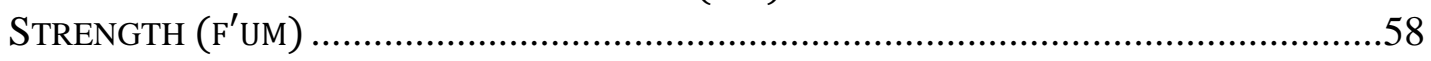

TABle 25: Bland (2011), Herskedal (2012) vs. Tested Material Strength ............60

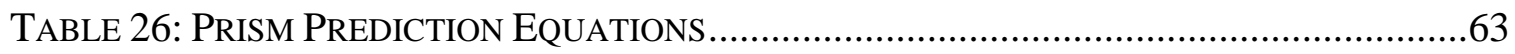

TABLE 27: Un-GROUTED PRISM PREDICTION EQUATION ..............................................64

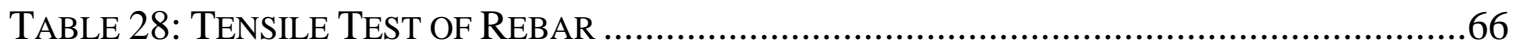

TABle 29: Rebar Area vs. Grout Cell Area............................................................68

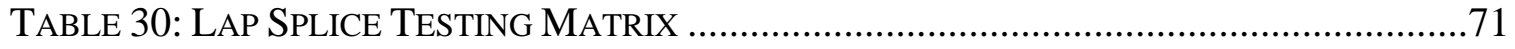

TABle 31: Tested LAP SPLiCE Length (LD) OF SPECIMENS ........................................74

TABLE 32: SumMARY Of YIELDING LAP SPLICE SPECIMENS .........................................85

TABLE 33: REQUiRED LENGTH FOR M10 (\#3) BAR TO REACH 125\% YIELD OF

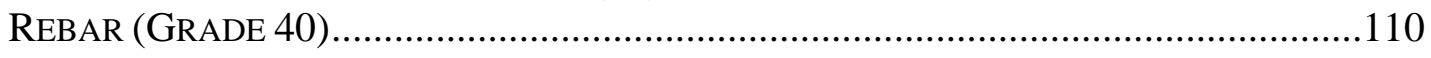

TABLE 34: REQUIRED LENGTH FOR M13 (\#4) BAR TO REACH 125\% YIELD OF

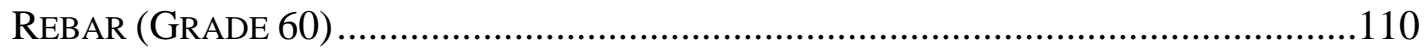

Table 35: MSJC Predicted Lap Splice Strength (Tr) vs. Measured STRENGTH (TM) (\#3 SIZED REBAR) ..................................................................117

TABle 36: MSJC PRedicted Lap Splice Strength (Tr) vS. MEasured

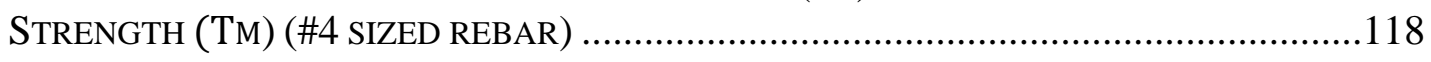

Table 37: Summary of Weak Grout Lap SPlice SPecimens ....................................119

TABle 38: Summary Of Medium Grout Lap Splice Specimens..................................122 
TABle 39: Summary of Strong Grout Lap SPlice Specimens

TABLE 40: SumMARY OF WEAK GROUT Dimensions AND COMPRESSIVE

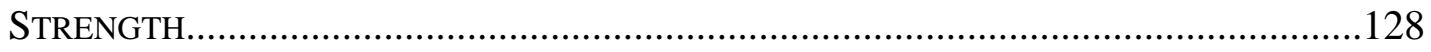

TABle 41: Summary of Medium GROUt Dimensions AND COMPRESSIVE

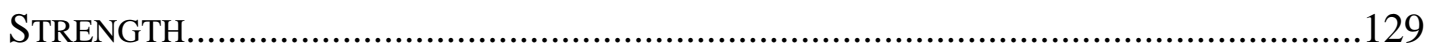

TABle 42: Summary OF Strong GROUT Dimensions And COMPRESSIVE

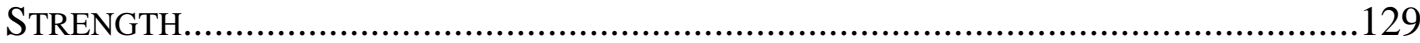

TABle 43: ICEB Prism Strength (F'M) vs. ICEB Unit BAtCh STREnGTH ..................130 


\section{LIST OF FIGURES}

FIGURE 1: EXAMPLES OF HOLLOW CEB UNITS

FIGURE 2: ICEB UNIT FROM BLAND 2011 (LEFT) AND ICEB UNIT DIMENSIONS FROM WHEELER 2005 (RIGHT) .......................................................................

Figure 3: Soeng Thai Interlocking Compressed EARTh Block Press Model BP6 WITH BLOCK TYPES (ADAPTED FROM WHEELER, 2005) ...................................6

Figure 4: Half Block Masonry Test Set Up (From Hammons et AL., 1994) ............16

Figure 5: Drawing of Symmetrical Lap Splices in M13 (\#4) Rebar Specimen

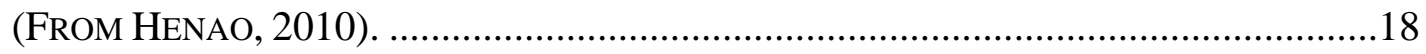

Figure 6: Soeng Thai Interlocking Compressed Earth Block Press Model BP6. .20

Figure 7: GRAin SizE ANALYSIS PER ASTM D422-63 OF MATERIALS (FROM

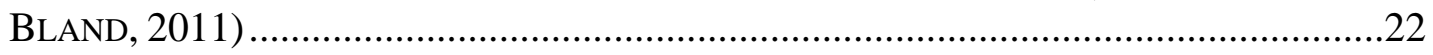

Figure 8: Soeng Thai Model SP3 Soil Pulverizer (From Bland, 2011)...................23

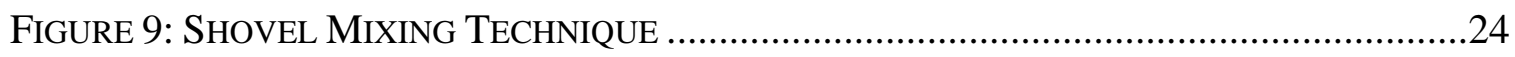

Figure 10: StANDARD Soil Consistency Drop Test (FROM PROTO ET AL., 2010).........26

Figure 11: Pocket Penetrometer .........................................................................28

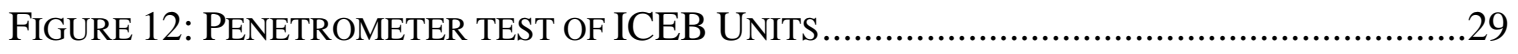

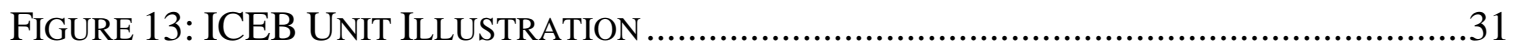

FigURE 14: ICEB UnIT COMPRESSION TEST SET UP ...................................................32

Figure 15: ICEB Unit Strength $\left(f^{\prime} b s\right)$ vs. Temperature at Pressing (Tp) ...............36

Figure 16: ICEB Unit Strength $\left(f^{\prime} b s\right)$ vs. Humidity at Pressing (HP) ....................37

Figure 17: Non-Porous WeAK Grout SPECIMEN (LEFT) AND MEDIUM GROUT SPECIMEN (RIGHT) TEST SET UP AND INSTRUMENTATION .....................................45

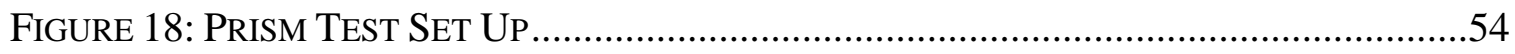


FigURE 19: TyPICAL FAILURE SHAPE OF PRISM..............................................................55

Figure 20: ICEB Unit Compressive StRENGTH $\left(f^{\prime} b\right)$ vs. PRISM Compressive

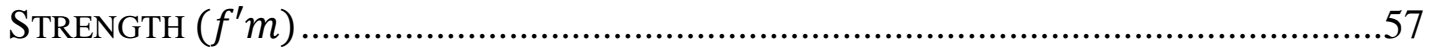

Figure 21: Grout Compressive Strength $\left(f^{\prime} g\right)$ vs. Prism Compressive

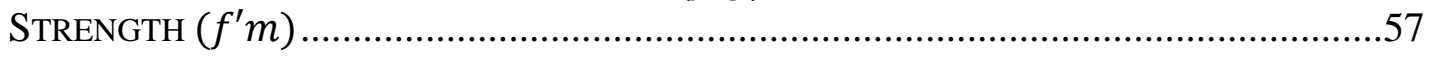

Figure 22: ICEB PRISM STRENGTH ( $\left.\mathrm{F}^{\prime} \mathrm{M}\right)$ VS. ICEB BATCH COMPRESSIVE STRENGTH $\left(\mathrm{F}^{\prime} \mathrm{B}\right)$

FiguRE 23: RELATIONSHIP BETWEen ICEB UNIT STRENGTH, F’B AND ICEB PRISM STRENGTHS, F'M \& F'MU ..........................................................................65

Figure 24: SAtec Universal Test Machine From Sterling (2011) .............................66

Figure 25: LAP Splice Rebar ORIENTATION With RESPect to Side Grouting

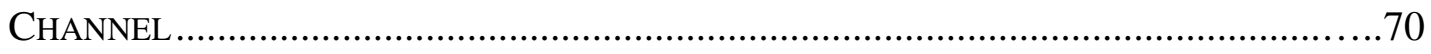

Figure 26: Typical INSTALLATION, SPECIMEN 4WW1000 (LEFT) AND

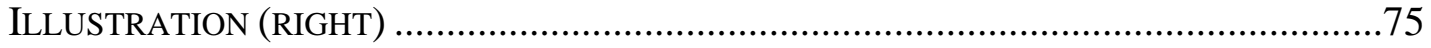

Figure 27: DAYTON BAR LOCK ® COUPLER FROM THE DAYTON ONLINE CATALOG (2011) (LEFT) AND WELDED COUPLERS FOR SIZES \#3 (YELLOW) AND \#4 (RED) REBAR (RIGHT) ..................................................

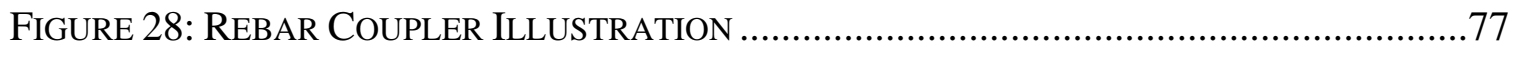

FIGURE 29: STRIPPED REBAR FROM 3SS700 SPECIMEN .....................................................77

FIGURE 30: EFFECTS OF REBAR ECCENTRICITY ON SPECIMEN 4SM700 ...............................79

Figure 31: Typical Longitudinal FaILURe Mode of ICEB LAP SPLice SPECIMENS (LEFT) AND PROPAGATION OF TOP CRACK ALONG ICEB UNIT/GROUT INTERFACE (RIGHT)

Figure 32: RAdial Stresses DeVeloped Against Grout From Tensile FORCE FROM HAMMONS ET AL. 1994.

Figure 33: LATERAl SplitTing Forces DeVeloped during LAP SPlice Testing FROM HAMMONS ET AL. (1994) (LEFT) AND LONGITUDINAL CRACK DEVELOPMENT AT TOP OF BLOCK FROM HAMMONS ET AL. (1994). 
Figure 34: Pull Out Failure of Rebar Lap SPlice AND ToP ICEB UNIT UPLIFT ON SPECIMEN 3SM700.

Figure 35: AXIAL DisPlaCEMENT VS. LOAD FOR STRONG GROUTED M10 (\#3 BAR)

LAP SPLICE SPECIMENS.

Figure 36: Axial DisPlacement vs. LOAD FOR StRong Grouted M13 (\#4 BAR) LAP SPLICE SPECIMENS.

Figure 37: Axial DisPlacement Vs. LOAD FOR MEDIUM GROUTED M10 (\#3 BAR) LAP SPLICE SPECIMENS

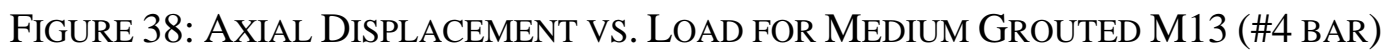

LAP SPLICE SPECIMENS.

Figure 39: AXIAL DisPlacEMENT VS. LOAD FOR WEAK GROUTED M10 (\#3 BAR)

LAP SPLICE SPECIMENS.

Figure 40: Axial DisPlaceMENT VS. LOAD FOR WEAK GROUTED M13 (\#4 BAR)

LAP SPLICE SPECIMENS.

Figure 41: Predicted MSJC Lap Splice Strength (Tr $)$ VS. Measured LaP SPLICE STRENGTH $(\mathrm{Tm})$

Figure 42: MEASURED LAP SPLICE STRENGTH ( $\mathrm{Tm}$ ) OF \#3 SIZED BAR VS. ICEB UNIT STRENGTH $\left(f^{\prime} b\right)$

Figure 43: MEAsured LAP SPLiCe STRENGTH ( $\mathrm{Tm}$ ) OF \#4 SIZED BAR VS. ICEB UNIT STRENGTH $\left(f^{\prime} b\right)$ .95

Figure 44: Measured Lap Splice Strength ( $\mathrm{Tm}$ ) OF \#3 Sized bar Vs. GRout STRENGTH $\left(\mathrm{F}^{\prime} g\right)$ .96

Figure 45: MeAsured Lap Splice Strength ( $\mathrm{Tm}$ ) OF \#4 SiZEd BAR VS. GROUT STRENGTH $\left(f^{\prime} g\right)$

Figure 46: Measured Lap Splice Strength ( $\mathrm{Tm}$ ) OF \#3 Sized Bar Vs. Prism STRENGTH $\left(f^{\prime} m\right)$

Figure 47: Measured Lap Splice Strength ( $\mathrm{Tm}$ ) OF \#4 Sized BAR VS. Prism STRENGTH $\left(f^{\prime} m\right)$. .99

Figure 48: Relationship Between Measured and PRedicted Lap Splice CAPACITIES FOR \#3 SIZED BAR (EQUATION 5.1) 
Figure 49: Relationship between Measured and Predicted Lap Splice CAPACITIES FOR \#4 SIZED BAR (EQUATION 5.1)

Figure 50: Relationship between Measured and Predicted Lap Splice CAPACITIES FOR \#3 SIZED BAR (EQUATION 5.2) .104

Figure 51: Relationship betweEn Measured and Predicted Lap Splice CAPACITIES FOR \#4 SIZED BAR (EQUATION 5.2) .104

Figure 52: ReQuire Lap SPlice Length VS. MASONRy Compressive StRENGTH FOR M10 (\#3) BARS.

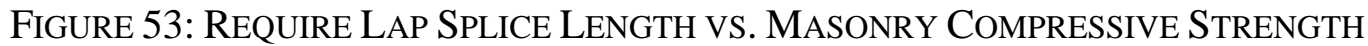
FOR M13 (\#4) BARS

FiguRE 54: REQUiRE LAP SPLICE LENGTH VS. ICEB UNIT COMPRESSIVE STRENGTH FOR M10 (\#3), GRADE 40 BARS

Figure 55: REQUiRE LAP SPLICE LENGTH VS. ICEB UNIT COMPRESSIVE STRENGTH FOR M13 (\#4), GRADE 60 BARS .............................................................................109

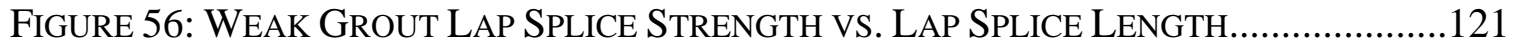

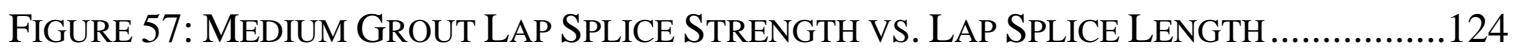

FigURE 58: StRong GROUT LAP SPLICE StRENGTH VS. LAP SPLICE LENGTH....................127 


\section{INTRODUCTION}

Humans have long used earth (soil) as a reliable building material since prehistoric times. Today, it continues to be used in developing countries as a primary construction material in many types of structures. In more developed countries, such as the United States, the ancient building material has seen a recent revival in modern times as environmentally mindful people pursue sustainable building materials and methods. There are many types of building methods for structures constructed from soil. Rudimentary earth structures can be built by hand with simple coursed mud construction, where handfuls of moist mud are piled into a wall form and allowed to dry before another layer or course of moist mud is added (Contreras 2006). Alternatively, mud can be mixed with rock or fibrous plant material to create a stronger composite structure (cob) that can be constructed in a similar coursed construction method. Mud that is mixed with an organic binding material, such as straw or rice husks, and allowed to dry in bricks (adobe or mud bricks) is extremely durable in dry conditions and have created some of the oldest existing standing buildings in the world. Although not as widely used, sod or turf structures can also be created by cutting thickly-rooted grass into rectangular sections and stacking each section on top of the other.

Earth blocks or walls formed by rammed earth construction are created by the compaction of soil by way of an external force. Both building materials can be created by traditional hand and stick compaction methods or with a more robust and expensive automated machine presses. An earthen block that is created using an artisanal (manual) or industrial (hydraulic) press is often referred to as a compressed earth block (CEB). For 
CEBs, soil is often compressed inside a machined mold and extracted to dry or cure. For rammed earth construction, soil is compacted inside temporary wall formwork and allowed to dry or cure within the formwork. The compaction techniques used in the creation of both earth blocks and rammed earth walls can vary widely. Earth blocks can be created and assembled using native soils available on-site or manufactured off-site and later shipped to the construction area. Monolithic structures created with rammed earth must have supplies and compaction tools on site for construction.

Structures built with only compacted soil, although usually strong when dry, have a tendency to absorb moisture and can collapse when saturated with water (Jagadish 2007). Burnt or fired bricks can be used as a more durable and stable building unit. However, brick firing requires thermal energy derived from coal, wood or other biomass material which can have environmental consequences. Alternatively, CEBs can be stabilized without the use of brick firing with the addition of binding agents (lime or cement) that are mixed in with the soil prior to compaction.

Although the technologies to compact and stabilize soil for building construction vary widely, a properly designed compressed earth block remains a cost effective, sustainable, and dependable building material. Even with these distinct advantages, there remains a significant lack of understanding of the engineering fundamentals of this building technology. 


\subsection{Improvements in Compressed Earth Technology}

The first recorded use of a mechanical steel press to produce stabilized CEB units can be traced back to the 1950's. The original CEB mechanical steel press (CINVA-Ram) was created by the International American Housing Center (Spanish acronym: CINVA) in 1956 and was used nearly exclusively in South America (Pacheco-Torgal and Jalali, 2012). CEB units produced from the CINVA-Ram press are solid rectangular blocks that are stacked and mortared like fired bricks. The geometric shape of the compressed earth block is directly dependent on the geometry of the press in which it was formed. Using a machined mold press to compress earth into a specific geometric shape has its advantages over traditional hand pressed earthen blocks or adobe. CEB units that are formed in a mechanical press are typically denser, stronger, and more water resistant than units produced from traditional hand and stick press methods (Morel et al., 2004). Structures built with solid CEB units, like those from the original CINVA-Ram press, are typically unreinforced. Since the introduction of CINVA-Ram CEB unit in the 1950's, adaptions and advancements to the CEB geometry have been made. Most notably, grouting chambers have been introduced to several CEB units that create a hollow chamber that allow for the full grouting and rebar reinforcement of the CEB structure (Figure 1). 


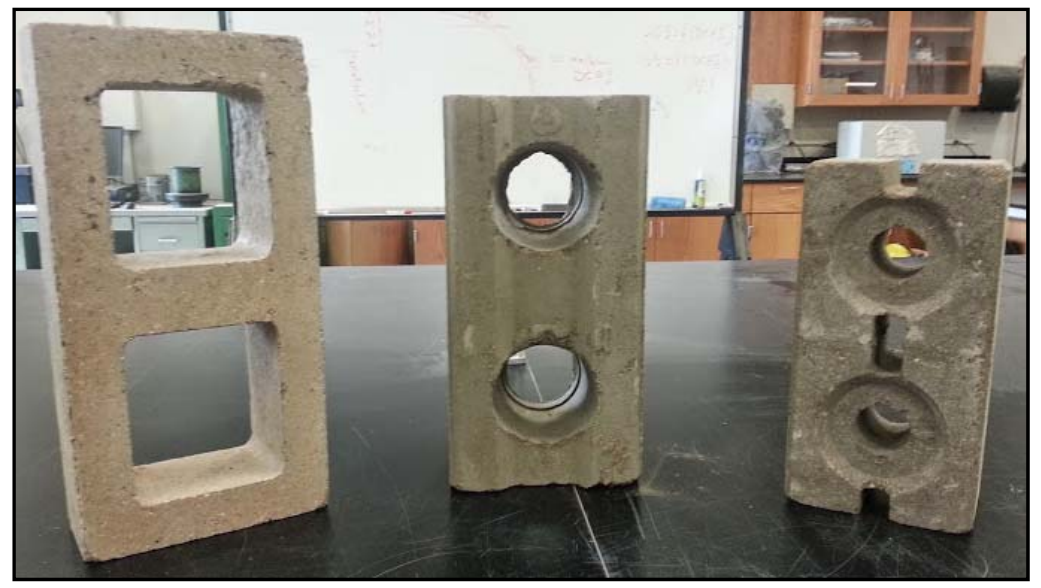

Figure 1: Examples of Hollow CEB Units

The geometry of the CEB unit can influence the compressive strength and constructability of the CEB structure. One such CEB geometry is the Interlocking Compressed Earth Block (ICEB), which can be formed in either a manual or automatic mechanical press. The ICEB differs from a traditional CEB in that it has interlocking dowels that allow the units to easily stack together during construction. ICEB units have emerged as an inexpensive and viable alternative to other methods of construction (Rael 2009). The units are formed from specified quantities of pulverized dirt, cement or lime (for stabilization), sand, and water that are mixed together and compressed into the ICEB shape with a manual or mechanical press. A manual press is often the preferred choice for smaller or rural communities, where supporting a mechanical or hydraulic ICEB unit press is economically and logistically impractical. The low-tech and labor-intensive production process of the manual press requires little training and allows for the immediate employment of a local population. 


\subsection{Rhino Interlocking Compressed Earth Blocks}

This research investigates material properties and strength of ICEB units commonly referred to as "Rhino Blocks” (Figure 2). The standard Rhino Block is a 100 x 150 x 300 mm (4 x 6 x 12 inch) ICEB unit, shown below in Figure 2 and 3 (typical dimensions are given in centimeters). This ICEB unit is composed of two hollow reinforcement holes used for vertical grouted reinforcement, three grout key channels that are typically filled with grout to provide additional structural stability, and two interlocking dowels to stack and align adjacent ICEB units (Wheeler 2005).

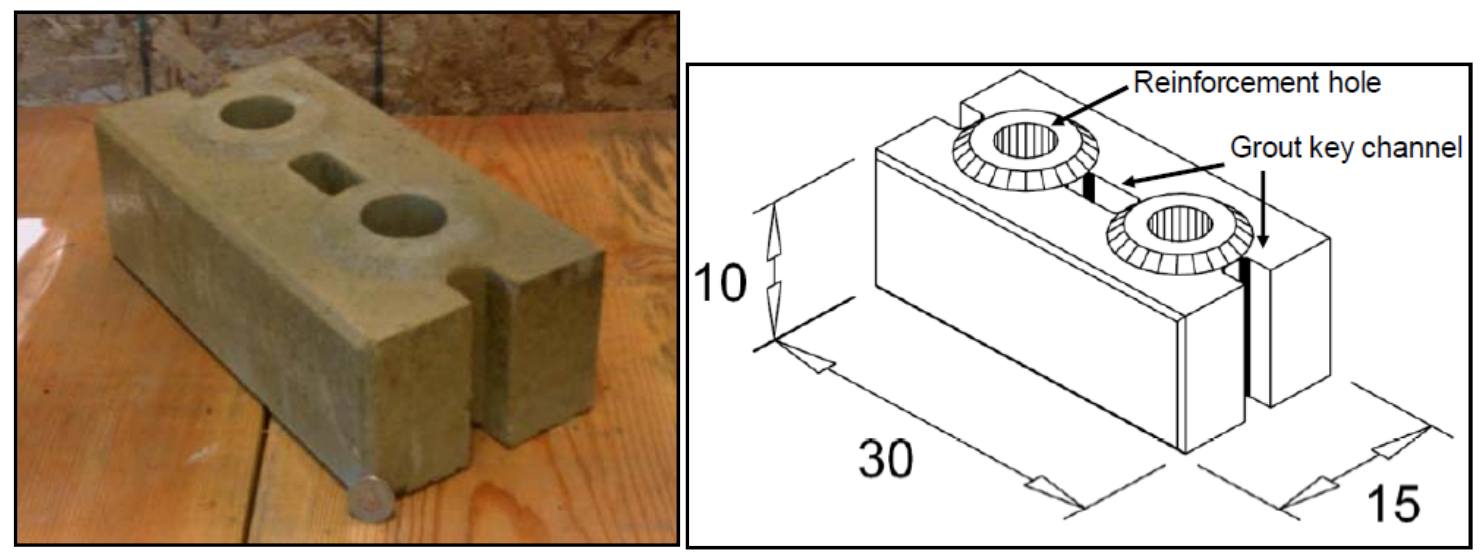

Figure 2: ICEB Unit from Bland 2011 (left) and ICEB Unit Dimensions from Wheeler 2005 (right)

\subsection{Rhino Interlocking Compressed Earth Block Press}

This research investigates ICEB strengths of ICEB half units manufactured using the manual Soeng Thai Model BP6 press (Figure 3) currently produced under the guidance and direction of the Centre for Vocational Building Technology (CVBT), a nongovernmental organization in Thailand (Wheeler 2005). The BP6 press can create several 
ICEB units with varying geometries by adding or removing internal steel plate inserts (Table 1).

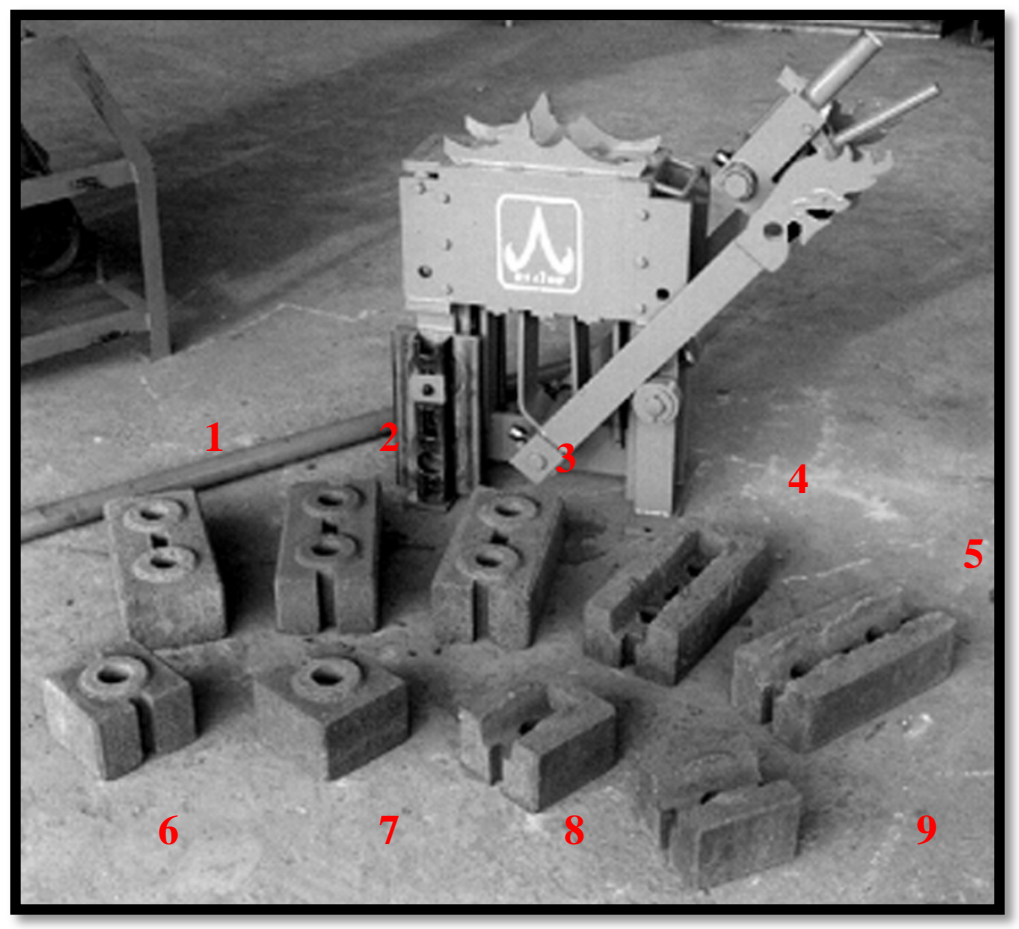

Figure 3: Soeng Thai Interlocking Compressed Earth Block Press Model BP6 with Block Types (Adapted from Wheeler, 2005)

Table 1: Soeng Thai ICEB Unit Types and Descriptions

\begin{tabular}{|c|c|c|c|c|c|}
\hline $\begin{array}{c}\text { Block } \\
\text { Number } \\
\text { (See Figure } \\
\text { 4) }\end{array}$ & Block Type & $\begin{array}{c}\text { Number of Side } \\
\text { Grouting Key } \\
\text { Channels }\end{array}$ & $\begin{array}{c}\text { Block Number } \\
\text { (See Figure 4) }\end{array}$ & Block Type & $\begin{array}{c}\text { Number of } \\
\text { Side Grouting } \\
\text { Key Channels }\end{array}$ \\
\hline 1 & Full Block & 0 & 6 & Half Block & 2 \\
\hline 2 & Full Block & 2 & 7 & Half Block & 1 \\
\hline 3 & Full Block & 1 & 8 & $\begin{array}{c}\text { Channel Half } \\
\text { Block }\end{array}$ & 1 \\
\hline 4 & Channel Block & 1 & 9 & $\begin{array}{c}\text { Channel Half } \\
\text { Block }\end{array}$ & 2 \\
\hline 5 & Channel Block & 2 & \multicolumn{2}{|c}{} \\
\cline { 1 - 3 } & & & & &
\end{tabular}




\subsection{Lap Splice Applications in ICEB Structures}

Reinforcing rebar is critical to resisting the tensile forces that develop within masonry structures. These forces may develop when structures are subjected to shear forces from seismic or wind events. Masonry structures, including those built from ICEB units, that are not appropriately designed to withstand shear forces may run a risk of failure (Sattar, 2010). The installation of a single continuous strand of rebar from foundation to ceiling

in single story ICEB structures is sometimes impractical as each ICEB unit must be lifted and threaded over the top of the rebar during construction. An alternative to installing a continuous strand of rebar is using two overlapping segments, often referred to as a lap splice, to transfer the tensile force. Lap splices are used in most concrete and masonry construction applications. Numerous research studies have been completed previously to study lap splice performance in concrete and masonry specimens. However, research on the strength of lap splices in ICEB structures is practically non-existent; the requirements and constraints of lap splices in ICEBs are not well understood. Additionally, lap splices can also improve the constructability of masonry structures. Lap splices allow for hollow masonry units to be threaded over shorter rebar lengths, reducing construction labor and construction time.

\subsection{Research Purpose and Significance}

The purpose of this research is to determine the required development length and rebar size for lap splices in ICEB specimens. The required lap splice length of rebar installed within ICEB units is currently unknown. No past research is readily available on the 
subject. This research also investigates the compressive strengths of ICEB units and grout specimens of varying compositions that form fully grouted ICEB prisms. All ICEB units produced for this research were ICEB half units with one side grouting channel (Type 7, See Table 1). Since no standard ICEB construction manual exists for this unit type, the results are compared against both the current construction practices and the governing masonry construction manual, the Masonry Standards Joint Committee (MSJC). This paper is part of a larger effort at California Polytechnic State University to understand the engineering fundamentals and principles of ICEB units, specifically those produced by the BP6 press.

\subsection{Research Scope}

Construction of all grout and ICEB unit specimens were limited to a single soil and sand type (See Chapter 3.2). All ICEB units used in this research were pressed from the Soeng Thai Interlocking Compressed Earth Block Press Model BP6. No other block press was used in this research. Sizes M10 (\#3) and M13 (\#4) rebar were used to construct all lap splices (Chapter 3.8).

\subsection{Experimental Program}

This research investigates material relationships that control the strength of ICEB prisms and lap splices. The research investigates the following five key elements that determine the strength of a lap splice:

i. $\quad$ Length of Rebar Lap Splice $\left(l_{d}\right)$

ii. Diameter of Rebar $\left(d_{b}\right)$ 
iii. ICEB Unit Strength $\left(f^{\prime}{ }_{b}\right)$

iv. Grout Strength $\left(f_{g}^{\prime}\right)$

v. Prism Strength $\left(f^{\prime}{ }_{m}\right)$

This research tested 43 fully grouted ICEB lap splice specimens of varying rebar bar size, strength, and lap splice length for ultimate tensile capacity. The research also tested 27 fully grouted ICEB prism specimens for compressive strength. Single ICEB units, grout specimens, and reinforcing rebar were individually tested as described in Chapter 3. 


\subsection{Organization of Contents}

The research presented in this paper is organized into seven sections as summarized below.

Chapter 2, Literature Review, presents a comprehensive summary of past research pertinent to the testing of ICEB units and lap splice specimens. A summary of other Cal Poly ICEB research is also presented in this section.

Chapter 3, Materials and Properties, details the materials used in the construction of all specimens in this research. Testing procedures and results are presented in this section for all grout, ICEB unit, and prisms specimens. A prediction equation to calculate the compressive strength of fully grouted and un-grouted prisms is described in this chapter.

Chapter 4, ICEB Lap Splice Construction and Test Set Up, summarizes the methodology of construction and instrumentation of lap splice specimens. Specific construction procedures and timelines are summarized in this section.

Chapter 5, Lap Splice Experimental Results and Analysis, describes the testing procedure for the tensile loading of ICEB specimens. This section summarizes the experimental results from the ICEB lap splice testing. A prediction equation to calculate the required lap splice length of ICEB units is presented in this chapter.

Chapter 6, Conclusions and Recommendations, provides the final conclusions and recommendations for ICEB lap splices and ICEB materials. 


\section{LITERATURE REVIEW}

The following section discusses prior supporting research in compressed earth blocks and lap splices in concrete masonry units. While numerous studies have been completed previously to study lap splices in concrete and masonry units, no notable research has been completed in the realm of ICEBs. Moreover, the engineering fundamentals of ICEB units and the structures built from them are not well understood.

\subsection{Previous Completed ICEB Research at Cal Poly}

This research is the third ICEB Master's thesis completed at Cal Poly, San Luis Obispo under the guidance of the Civil \& Environmental and Architectural Engineering Departments. This thesis builds off the knowledge gained in those past projects. Any findings assumed from those projects in this report are specifically detailed in this paper. The precursory ICEB projects and their respected authors are as follows:

\subsubsection{In Plane Cyclic Shear Performance of Interlocking Compressed Earth Block Walls. David Bland. 2011.}

David Bland constructed three 1800 mm x 1800 mm wall specimens out of cement stabilized ICEBs and subjected the walls to cyclic in-plane lateral loading. Bland found that the current ACI 530-08 masonry provisions significantly overestimate the shear strength of ICEB wall panels. 


\subsubsection{Flexural Behavior of Interlocking Compressed Earth Block Shear Walls Subjected to In-Plane Loading. Brad Sterling. 2011.}

Brad Sterling constructed a slim wall with a 2:1 height to width aspect ratio, a flanged

wall, and a wall with a window opening in the center out of cement stabilized ICEBs and subjected the walls to cyclic in-plane lateral loading. The failure mode of each wall was characterized by tensile yielding of the longitudinal rebar. Two types of analyses were conducted for calculating the ultimate strength of flexural dominant ICEB walls: a nonlinear static analysis model and a plastic analysis model.

\subsubsection{Investigation of Out-Of-Plane Properties of Interlocking Compressed Earth Block Walls. Nick Herskedal. 2012}

Nick Herskedal constructed five wall specimens out of cement stabilized ICEBs and subjected the walls to out-of-plane loading. Results showed that ACI 530 adequately predicts the yield strength of these walls, while ACI 530 over predicts the wall stiffness. Four specimens showed flexural behavior and failure and one showed brittle failure. Shear tie spacing limits were suggested.

\section{$2.2 \quad$ Morel et al. (2004)}

Morel et al (2004) tested several CEB half units, stacked two high, for compressive strength and found a linear relationship between cement content and compressive strength. Their research also notes a strong relationship between the compressed earth block dry density and the block compressive strength, with denser blocks providing 
greater strength. Blocks with a high moisture content correlated with a lower compressive strength.

\subsection{Walker and Stace (1996)}

Walker and Stace (1996) tested the compressive strength, drying shrinkage, wetting/drying durability, and water absorption of compressed earth blocks and found that all are improved by increasing cement content and impaired by increasing clay content. Soils with clay contents less than $15-30 \%$ were found to be most suitable. 


\subsection{MSJC Lap Splice Equation}

The MSJC (Masonry Standards Joint Committee) design and construction standards are used in the design and building of masonry structures. Due to the geometric similarities between ICEBs and standard masonry units, and because there is no complete or definitive building code for structures constructed from ICEBs, sometimes the MSJC is used to design ICEB structures. Per MSJC, the design equation for predicting adequate lap splice length $\left(l_{p}\right)$ in masonry is:

$$
\begin{gathered}
S I: l_{d}=\frac{1.57 d_{b}{ }^{2} f_{y} \gamma}{K \sqrt{f_{m}^{\prime}}} \\
{\left[U S: l_{d}=\frac{0.13 d_{b}{ }^{2} f_{y} \gamma}{K \sqrt{f_{m}^{\prime}}}\right]}
\end{gathered}
$$

Where:

$d_{b}=$ diameter of rebar; SI: mm [US: in]

$f_{y} \quad=\quad$ steel yield strength; SI: $\mathrm{N}$ [US: psi]

$f_{m}^{\prime} \quad=\quad$ compressive strength of masonry; SI: MPa [US: psi]

$k$ shall not exceed the smallest of the following: the minimum masonry clear cover, the clear spacing between adjacent reinforcement splices, and $5 d_{b}$.

$\gamma=1.0$ for No. $3(\mathrm{M \# 10)}$ though No. $5(\mathrm{M} \# 16)$ bars;

$\gamma=1.3$ for No. $6(\mathrm{M} \# 19)$ though No. $7(\mathrm{M} \# 22)$ bars; and,

$\gamma=1.5$ for No. $8(\mathrm{M \# 25)}$ though No. $9(\mathrm{M \# 29)}$ bars. 
Per MSJC Section 3.3.3.1, the maximum area of reinforcement should not exceed 8 percent of the cell area. Additionally, per MSJC Section 3.3.3.4, the minimum length of lap for reinforcement splices shall be $305 \mathrm{~mm}$ (12 in) or the development length determined by Equation 1, whichever is greater.

\subsubsection{Origins of MSJC Lap Splice Equation}

Lap splice specimens were constructed and tested for ultimate tensile capacity. A multiple regression analysis was used on the maximum lap splice tensile data to find the form of a good predictive model. The following equation was found to be the best prediction of measured capacities with the square of the Pearson product moment correlation coefficient equal to 0.932 .

$$
T_{r}=-176240+305.3 l_{d}+25204.3{d_{b}}^{2}+321.7 \sqrt{f^{\prime}{ }_{m t}}+3331.7 c_{c l}
$$

Where:

$T_{r} \quad=\quad$ predicted tensile strength, $\mathrm{lb}$

$l_{d} \quad=\quad$ tested length of lap splice, in

$f_{m t}^{\prime}=\quad$ tested compressive strength of masonry, psi

$c_{c l}=$ clear cover of structural reinforcement, in

Setting the predicted strength $\left(T_{r}\right)$ equal to $1.25 A_{b} f_{y}$ (or $25 \%$ over the yield strength of rebar) and solving for the tested lap splice length, MSJC arrived at:

$$
l_{d}=\frac{1.25 A_{b} f_{y}+17624.0-25204.3 d_{b}^{2}-321.7 \sqrt{f^{\prime} m t^{-}} 3331.7 c_{c l}}{305.3}
$$


This equation was fitted to Equation 1.2 in order to be practical for design purposes.

\subsection{Hammons et al. (1994)}

As part of a larger project to determine the critical material and design parameters of reinforced masonry, the authors performed single lap splice tests on half block reinforced masonry units (Figure 4).

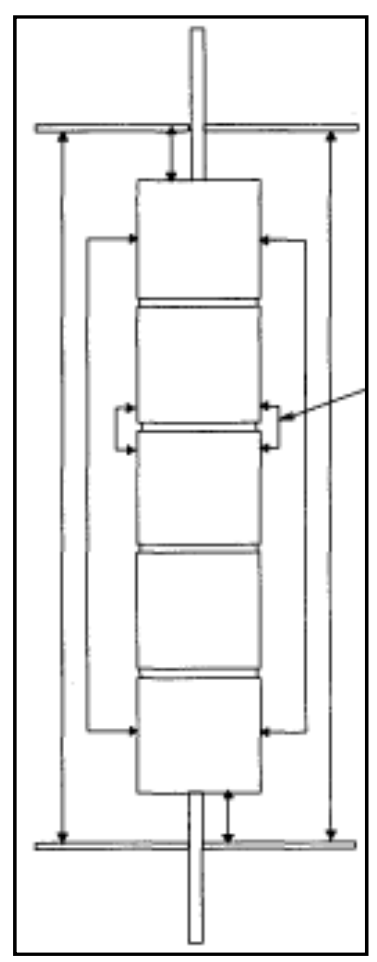

Figure 4: Half Block Masonry Test Set Up (From Hammons et al., 1994)

The typical observed failure modes of half block lap splice specimens were:

i. $\quad$ Reinforcing bar pullout

ii. Reinforcing bar pullout followed by masonry splitting

iii. Longitudinal masonry splitting along the splice

iv. Yielding of the rebar 
Tests were focused on investigating parameters which affected the strength and ductility of fully grouted concrete and clay masonry construction. The research aimed to build upon current knowledge of lap splice in reinforced masonry so that an accurate assessment of current design standards could be analyzed. The authors had success creating and testing a wide variety of lap splices in half masonry blocks. This allowed for the creation and data collection of many specimens. The study had several key findings, as summarized below:

i. The study found that the minimum cover distance and not unit width generally governs splice strength.

ii. Specimens constructed with a large bar to unit width ratio did not provide adequate splice strength to resist tensile splitting forces.

iii. Stronger clay units have a confining effect on lap splices, increasing resistance to tensile splitting

iv. Increasing unit width increases splice capacity and reduces the likelihood of failure by tensile splitting.

v. Increasing bar lap length increased splice strength when bar pullout governed splice strength 


\subsection{Henao (2010)}

Henao investigated lap splices in AAC masonry units and used the current lap splice provisions for clay and masonry to calculate AAC lap splice length. The testing program tested two identical and symmetrical lap splices as shown in Figure 5 below.

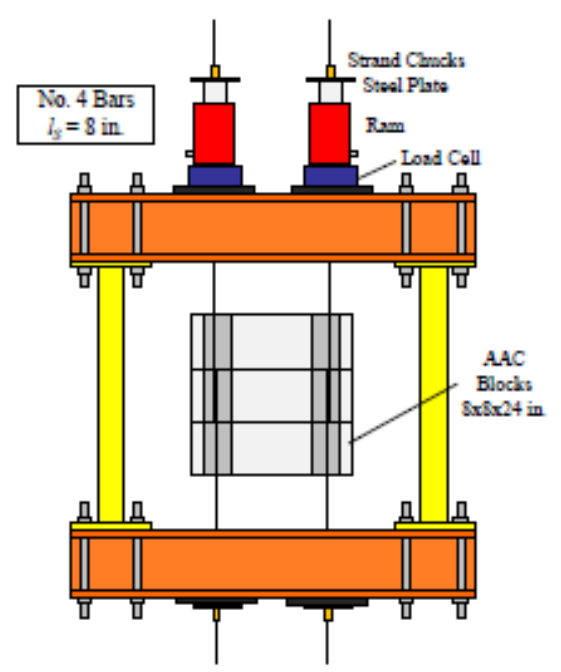

Figure 5: Drawing of Symmetrical Lap Splices in M13 (\#4) Rebar Specimen (From Henao, 2010).

Testing two rebar splices eliminated the threat of having an eccentric force couple that could be present with a single splice. The lap splices were pulled in tension by two air driven hydraulic pumps until one splice failed. All specimens failed due to longitudinal splitting of the grout. The average observed strength exceeded the predicted strength and failed due to longitudinal splitting for each set. The author thus concluded that the 2008 MSJC code for the design of lap splice are safe and reliable for ACC masonry. 


\subsection{Canbay and Frosch (2005)}

The objective of this research was to develop an expression for the calculation of bond strength based on a physical model of lap splice tension cracking. The authors stated that even while many lap splice studies have been completed, a theory based analysis procedure had not yet been developed. The researchers had several important findings, including:

(1) The authors concluded that there was a clear relationship between lap splice strength and lap splice length. The research showed that this relationship was not linear and was better predicted by the square root of $\sqrt{l_{d} / d_{b}}$ than with a linear relationship.

(2) In agreement with ACI Committee 408, using the fourth root of concrete compressive strength, $\sqrt[4]{f_{c}{ }^{\prime}}$, to predict lap splice strength is more accurate than using the square root. 


\section{MATERIALS AND PROPERTIES}

This chapter summarizes the materials used in construction of all interlocking compressed earth half blocks, prisms, and grout specimens in this research. Tables summarizing the strength of blocks, grout, and prisms specimens are also presented in this chapter.

\subsection{Interlocking Compressed Earth Block Construction}

All ICEB units used in this project were constructed on the Cal Poly San Luis Obispo campus by student volunteers in conjunction with and under direct supervision of the author. All ICEB units were created using the Soeng Thai Interlocking Compressed Earth Block Press Model BP6 (Figure 6).

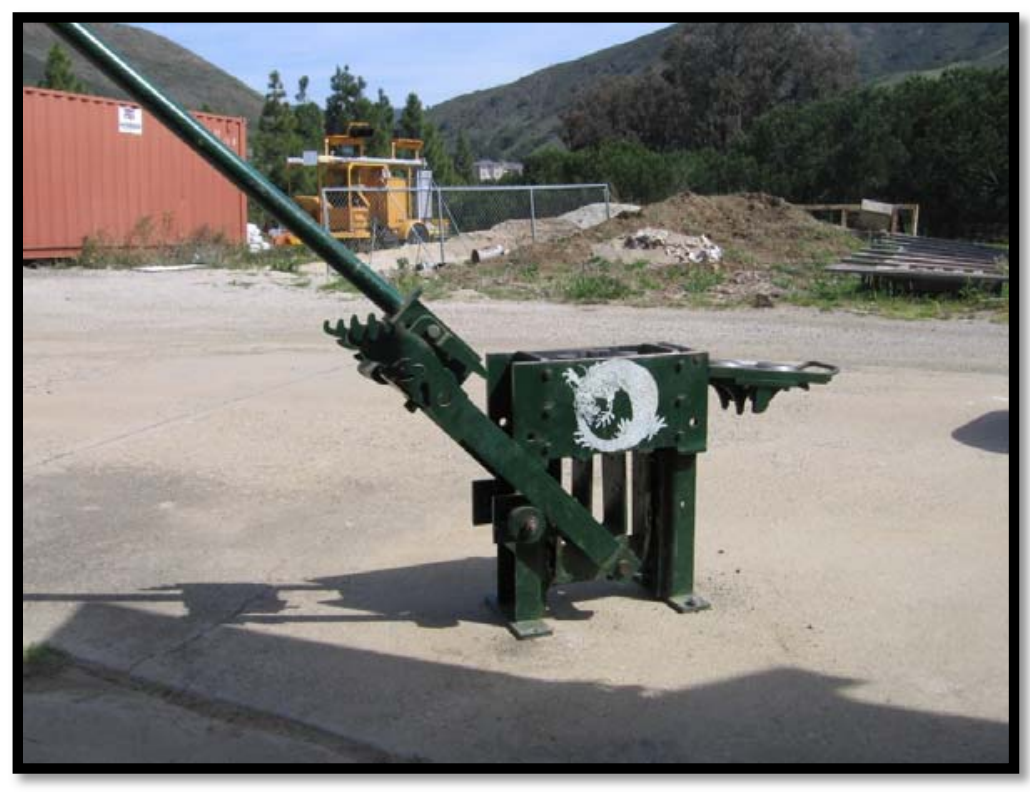

Figure 6: Soeng Thai Interlocking Compressed Earth Block Press Model BP6 


\subsection{ICEB unit Composition}

Strong, medium, and weak ICEB unit mixes were developed to achieve three separate compressive strengths with significant variance. All mixes were created by varying cement, soil, sand, and water proportions as defined in Section 3.4.

\subsubsection{Soil Properties}

The soil used in construction of all ICEB units came from a local excavation site and was the same soil used in prior ICEB research completed at Cal Poly in the Civil and Environmental Engineering Department and Architectural Engineering Department. The soil was selected based on its optimum clay content that was approximately $21 \%$ clay (Bland 2011). The plasticity of the soil was determined per ASTM D4318-05 (Table 2). A soil sieve analysis per ASTM D422-63 from Bland (2011) is presented in Figure 7.

Table 2: Soil Characteristics per ASTM D4318-05 from Bland (2011)

\subsubsection{Sand Properties}

\begin{tabular}{|c|c|c|}
\hline $\begin{array}{c}\text { Liquid } \\
\text { Limit }\end{array}$ & $\begin{array}{c}\text { Plastic } \\
\text { Limit }\end{array}$ & $\begin{array}{c}\text { Plasticity } \\
\text { Index }\end{array}$ \\
\hline $36 \%$ & $15 \%$ & $21 \%$ \\
\hline
\end{tabular}

The sand used for ICEB manufacturing and grout mixing originated from the Sisquoc River and was appropriate for use in concrete (per ASTM C33). The sand used in this research was the same sand used in prior ICEB research completed at Cal Poly. The sand was sieved with a number 4 sieve prior to mixing to remove larger particles. A sieve analysis grain size distribution per ASTM D422-63 from Bland (2011) is presented in Figure 7. 


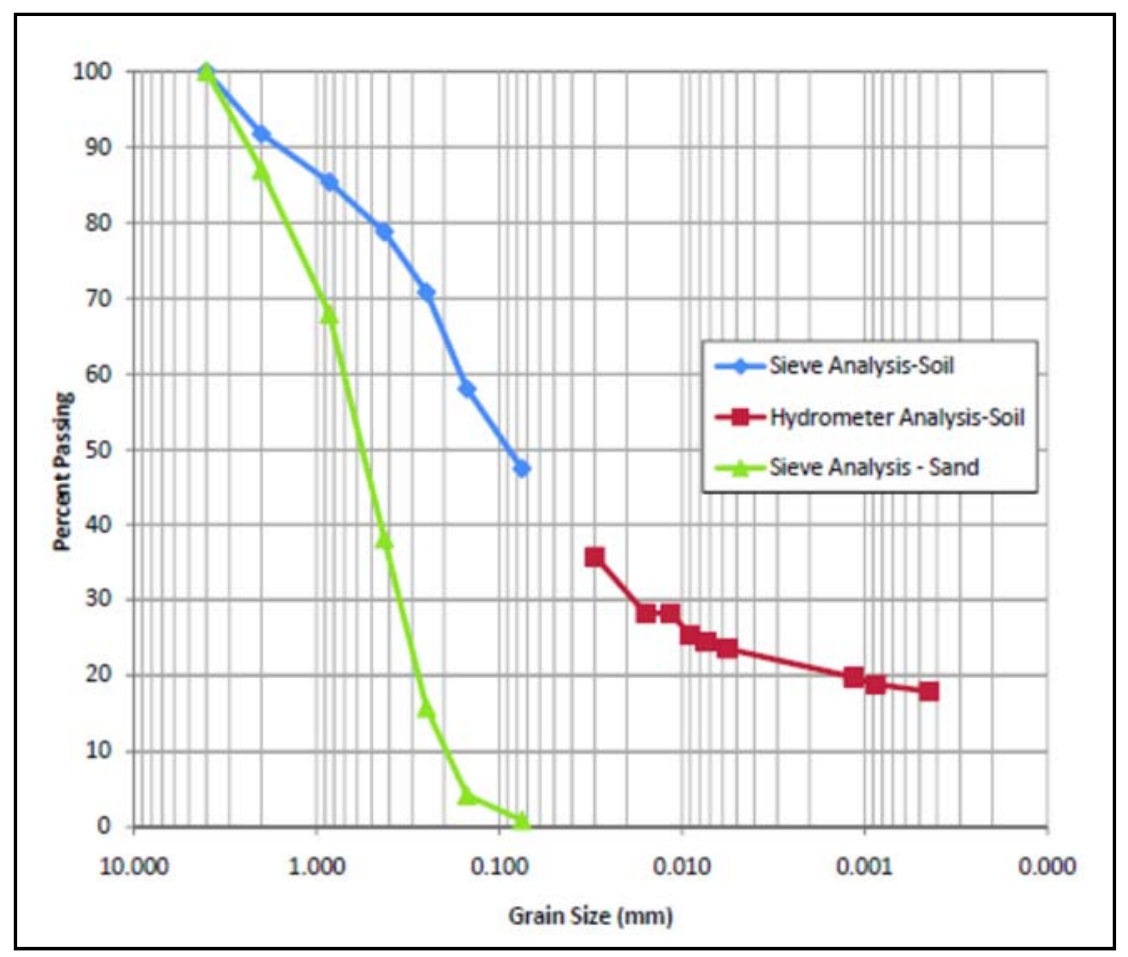

Figure 7: Grain Size Analysis per ASTM D422-63 of Materials (from Bland, 2011)

\subsubsection{Cement Properties}

All ICEB unit and grout mixes used the same readily available Type I/II portland cement. All cement was obtained from the same supplier. 


\subsection{Materials Preparation}

Soil was pulverized into a uniform consistency using a Soeng Thai Model SP3 soil

pulverizer (Figure 8). Pulverizing the soil broke down the large soil clumps and removed rocks from the soil.

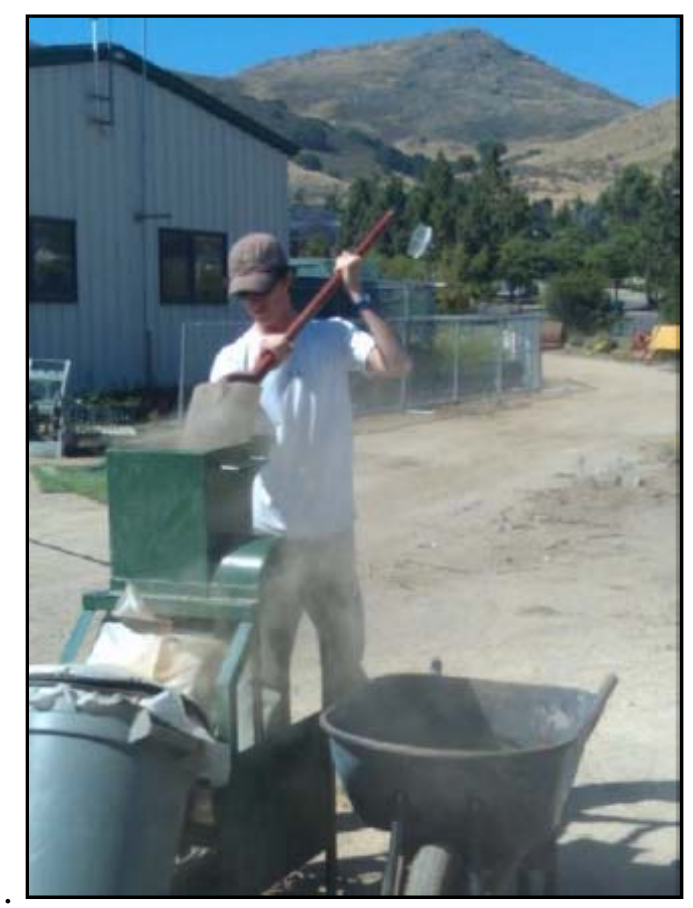

Figure 8: Soeng Thai Model SP3 Soil Pulverizer (from Bland, 2011)

The pulverized soil was transferred to bins and allowed to air dry inside a protected structure prior to use. Sand did not need to be pulverized. It was sieved in through a \#4 sieve and allowed to air dry inside the same protected shed. All materials used in the creation of ICEB units and grout were weighed and stored air dry. 


\subsection{Manufacturing of ICEB Units}

All ICEB manufacturing closely followed the guidelines and techniques set forth by prior research completed by David Bland and Brad Sterling in 2011. Any deviation is noted in this research.

\subsubsection{ICEB Unit Material Proportions}

To remain consistent with past Cal Poly ICEB research, material proportions for the medium strength ICEB units were duplicated from the material proportions used to create ICEB units in Bland (2011), Sterling (2011), and Hirskadal (2013). The weak and strong ICEB unit mixes (Table 3) were created by adjusting the cement, soil, and sand content until an appropriate strength was reached. Mixes that contained higher cement content required more water during mixing.

Table 3: Weak, Medium, and Strong ICEB Unit Mix Proportions

\begin{tabular}{|c|c|c|c|c|c|c|}
\hline \multirow{2}{*}{ Material } & \multicolumn{2}{|c|}{ Weak ICEB Unit Mix } & \multicolumn{2}{c|}{$\begin{array}{c}\text { Medium ICEB Unit } \\
\text { Mix }\end{array}$} & \multicolumn{2}{|c|}{$\begin{array}{c}\text { Strong ICEB Unit } \\
\text { Mix }\end{array}$} \\
\cline { 2 - 7 } & $\begin{array}{c}\text { Dry } \\
\text { Weight }\end{array}$ & \% of total & $\begin{array}{c}\text { Dry } \\
\text { Weight }\end{array}$ & $\%$ of total & $\begin{array}{c}\text { Dry } \\
\text { Weight }\end{array}$ & $\%$ of total \\
\hline Soil & $\begin{array}{c}60.0 \mathrm{~kg} \\
(132.3 \mathrm{lb})\end{array}$ & $88.9 \%$ & $\begin{array}{c}50.0 \mathrm{~kg} \\
(110.2 \mathrm{lb})\end{array}$ & $74.7 \%$ & $\begin{array}{c}43.0 \mathrm{~kg} \\
(94.8 \mathrm{lb})\end{array}$ & $62.9 \%$ \\
\hline Sand & $\begin{array}{c}0.0 \mathrm{~kg} \\
(0.0 \mathrm{lb})\end{array}$ & $0.0 \%$ & $\begin{array}{c}6.7 \mathrm{~kg} \\
(14.8 \mathrm{lb})\end{array}$ & $10.0 \%$ & $\begin{array}{c}8.2 \mathrm{~kg} \\
(18.1 \mathrm{lb})\end{array}$ & $12.0 \%$ \\
\hline Cement & $\begin{array}{c}1.7 \mathrm{~kg} \\
(3.8 \mathrm{lb})\end{array}$ & $2.5 \%$ & $\begin{array}{c}4.2 \mathrm{~kg} \\
(9.3 \mathrm{lb})\end{array}$ & $6.3 \%$ & $\begin{array}{c}10.0 \mathrm{~kg} \\
(22.1 \mathrm{lb})\end{array}$ & $14.6 \%$ \\
\hline Water & $\begin{array}{c}5.8 \mathrm{~kg} \\
(12.8 \mathrm{lb})\end{array}$ & $8.6 \%$ & $\begin{array}{c}6.0 \mathrm{~kg} \\
(13.2 \mathrm{lb})\end{array}$ & $9.0 \%$ & $\begin{array}{c}7.2 \mathrm{~kg} \\
(15.9 \mathrm{lb})\end{array}$ & $10.5 \%$ \\
\hline Total & $\begin{array}{c}67.5 \mathrm{~kg} \\
(148.8 \mathrm{lb})\end{array}$ & $100.0 \%$ & $\begin{array}{c}66.9 \mathrm{~kg} \\
(147.5 \mathrm{lb})\end{array}$ & $100.0 \%$ & $\begin{array}{c}68.4 \mathrm{~kg} \\
(150.8 \\
\text { lb })\end{array}$ & $100.0 \%$ \\
\hline
\end{tabular}


The clay content of the soil was 21\% (Table 4). Moreover, the clay content of each mix was directly proportional to the amount of soil in the mix.

Table 4: Clay Content of ICEB Mixes

\begin{tabular}{|c|c|c|c|}
\cline { 2 - 4 } \multicolumn{1}{c|}{} & $\begin{array}{c}\text { Weak } \\
\text { ICEB }\end{array}$ & $\begin{array}{c}\text { Medium } \\
\text { ICEB }\end{array}$ & $\begin{array}{c}\text { Strong } \\
\text { ICEB }\end{array}$ \\
\hline $\begin{array}{c}\text { Percent Clay } \\
\text { Content }\end{array}$ & $18.5 \%$ & $15.6 \%$ & $13.2 \%$ \\
\hline
\end{tabular}

\subsubsection{Material Mixing}

The cement, sand, and soil were individually weighed and then carefully added to a portable cement mixer. The dry ingredients were mixed to a uniform consistency. The mix was dumped on a clean concrete surface and water was added slowly to bring the mix to the desired moisture content (Figure 9).

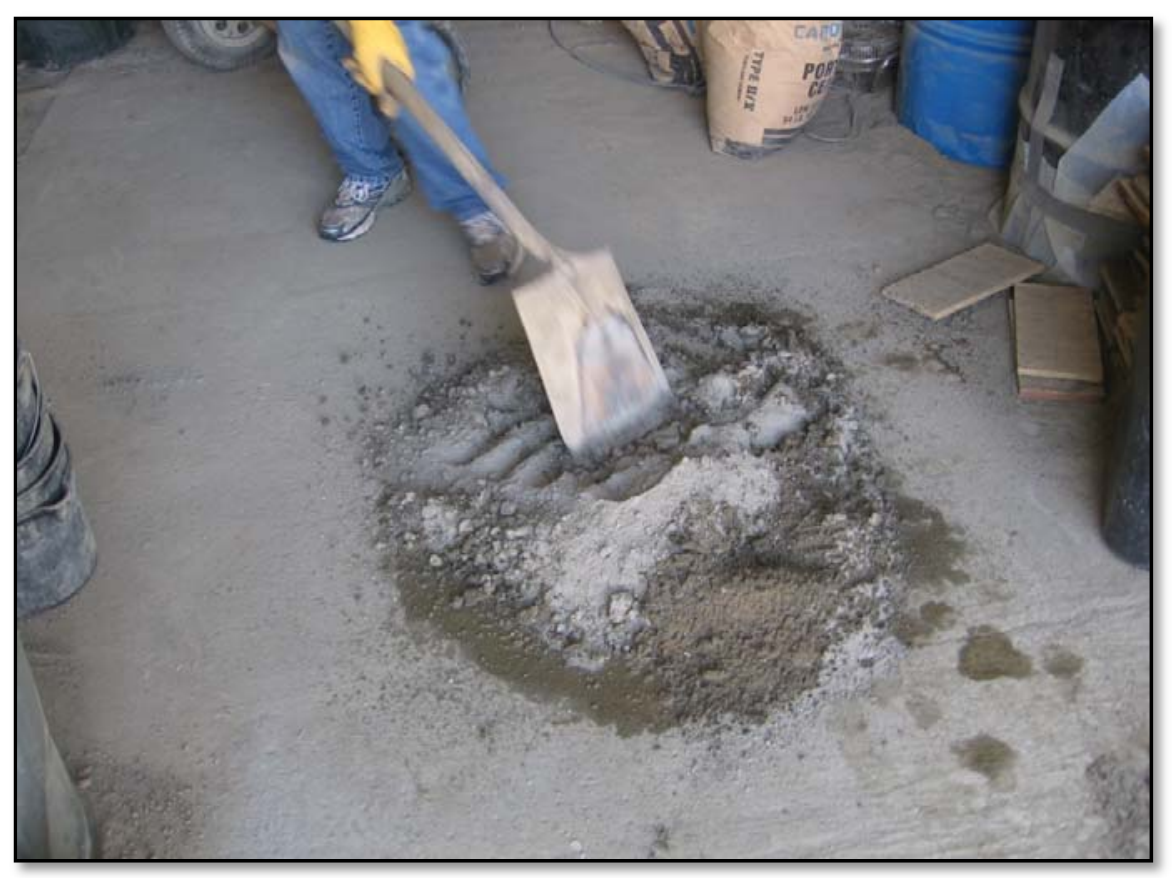

Figure 9: Shovel Mixing Technique 


\subsubsection{Optimum Water Content}

The optimum water content of an ICEB unit mix design is dependent on several factors. The soil mechanical properties, prevalent weather conditions, and the amount of time it took to create an ICEB unit were all important considerations when trying to mitigate the inherent variability of material and atmospheric water absorption. Small batches of the ICEB unit mix were made at a time to limit mix drying while the charges were waiting to be compressed. A visual "drop test" was used to determine if the mix had reached its appropriate water content. The drop test criteria are described below in Figure 10.

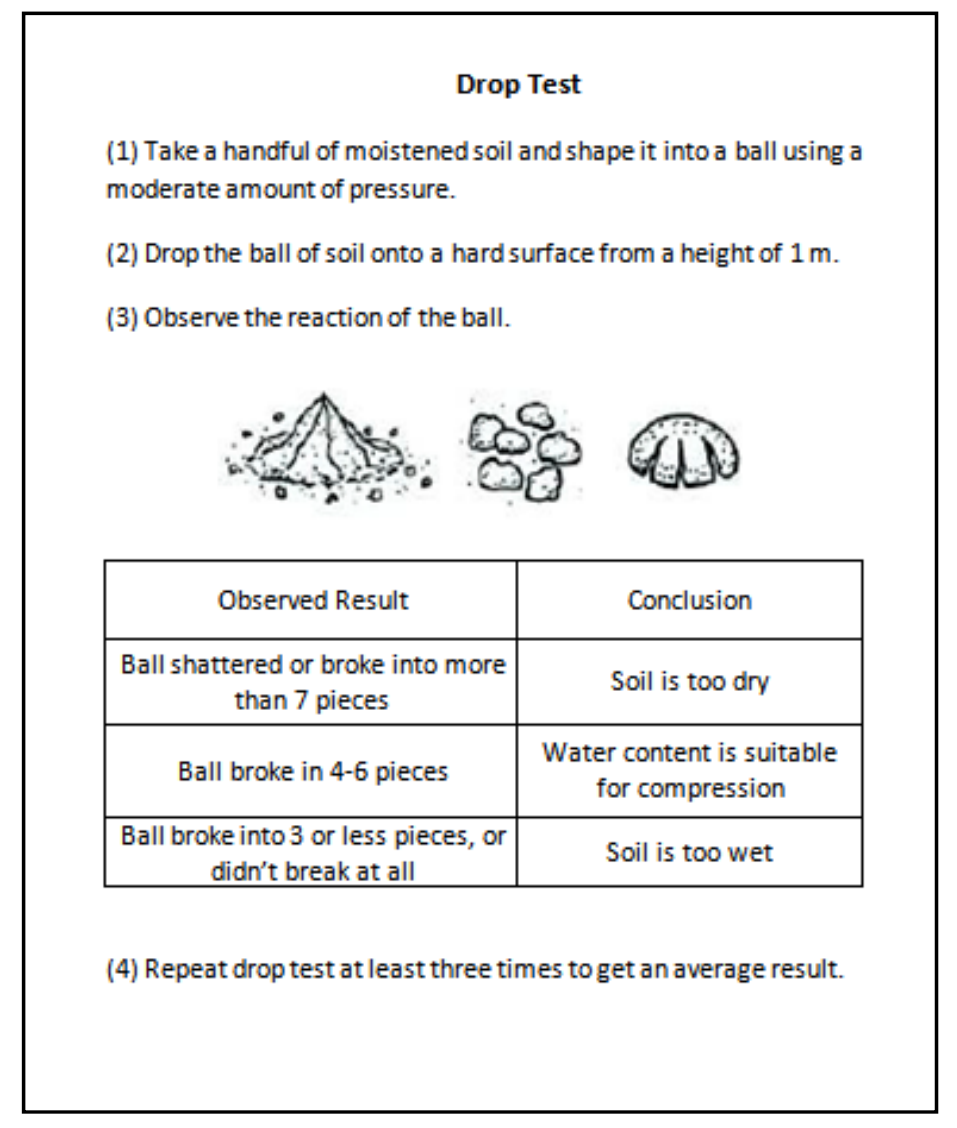

Figure 10: Standard Soil Consistency Drop Test (from Proto et al., 2010) 


\subsubsection{ICEB Mix Water Content}

A 5-kg sample from each ICEB unit mix type (weak, medium, and strong) was weighed immediately after mixing and again after unit pressing. This mix was then carefully transferred to a geotechnical drying oven and allowed to oven dry. ICEB unit mixes that contained higher soil (clay) contents correlated with greater overall water loss after the mix was oven dried (Table 5). ICEB unit mixes lost less than $1 \%$ of water when pressed within 1 hour of mixing. The water loss of ICEB unit mixes may be dependent upon the local prevailing weather conditions. Moreover, water loss may be greater in areas with high temperatures and lower humidity.

Table 5: Water Loss of ICEB Mixes

\begin{tabular}{|c|c|c|c|c|c|c|c|}
\hline \multirow{2}{*}{$\begin{array}{c}\text { ICEB } \\
\text { Type }\end{array}$} & \multicolumn{2}{|c|}{$\begin{array}{c}\text { Initial Weight and Conditions } \\
\text { of Mix }\end{array}$} & \multicolumn{2}{c|}{$\begin{array}{c}\text { Immediate Weight } \\
\text { After Pressing (1 hour) }\end{array}$} & \multicolumn{2}{c|}{ Oven Dried Weight } \\
\cline { 2 - 8 } & $\begin{array}{c}\text { Absolute } \\
\text { Weight }\end{array}$ & Temp. & Humidity & $\begin{array}{c}\text { Absolute } \\
\text { Weight }\end{array}$ & $\begin{array}{c}\text { \% Water } \\
\text { Loss }\end{array}$ & $\begin{array}{c}\text { Absolute } \\
\text { Weight }^{1}\end{array}$ & $\begin{array}{c}\text { W Water } \\
\text { Loss }\end{array}$ \\
\hline Weak & $\begin{array}{c}5000 \mathrm{~g} . \\
(176.4 \mathrm{oz})\end{array}$ & $57^{\circ} \mathrm{F}$ & $74 \%$ & $\begin{array}{c}4997 \mathrm{~g} . \\
(176.3 \mathrm{oz} .)\end{array}$ & $0.05 \%$ & $\begin{array}{c}4479 \mathrm{~g} . \\
(158.0 \mathrm{oz} .)\end{array}$ & $10.4 \%$ \\
\hline Medium & $\begin{array}{c}5000 \mathrm{~g} . \\
(176.4 \mathrm{oz})\end{array}$ & $61^{\circ} \mathrm{F}$ & $64 \%$ & $\begin{array}{c}4996 \mathrm{~g} . \\
(176.2 \mathrm{oz} .)\end{array}$ & $0.08 \%$ & $\begin{array}{c}4559 \mathrm{~g} . \\
(160.8 \mathrm{oz} .)\end{array}$ & $8.8 \%$ \\
\hline Strong & $\begin{array}{c}5000 \mathrm{~g} . \\
(176.4 \mathrm{oz})\end{array}$ & $61^{\circ} \mathrm{F}$ & $64 \%$ & $\begin{array}{c}4999 \mathrm{~g} . \\
(176.3 \mathrm{oz} .)\end{array}$ & $0.02 \%$ & $\begin{array}{c}4604 \mathrm{~g} . \\
(162.4 \mathrm{oz} .)\end{array}$ & $7.9 \%$ \\
\hline
\end{tabular}

(1) All absolute sample weights do not contain the weight of the container.

\subsubsection{Pressing and Extraction of ICEB Units}

Once the appropriate water content was reached, the ICEB unit mix was separated by weight into individual buckets (charges). Each charge weighed 8.3kg. Charges were then carefully poured into the open cavity of the press. A light hand press was required to carefully compact the loose volume of soil as it was poured into the cavity. It was 
important to ensure a uniform amount of mix was poured around the corners of the press to produce uniform and quality ICEB units. The corners of the ICEB units are typically the most fragile area of the ICEB unit. Compression was held for a minimum of two seconds before the ICEB unit was ejected from the press. Before the ICEB unit was removed from the press, a pocket penetrometer with a puncture depth and diameter of $1 / 4$ inch was used to check for consistency (Figure 11and 12). The capacity of the penetrometer was $67 \mathrm{~N}$ (15 lbs.). Any ICEB unit that did not meet the penetration resistance of the penetrometer immediately after pressing was immediately discarded. An ICEB unit could fail the penetrometer test in two ways. First, if the penetrometer force was applied and the tip of the penetrometer punctured the ICEB unit deeper than 1/4" then the ICEB unit was not dense enough and not suitable for this research. Second, if the tip of the penetrometer punctured the ICEB unit less than $1 / 4$ " or did not imprint on the ICEB unit at all, then the ICEB unit was too dense. Approximately 5\% of ICEB units were discarded from this research due to failing the penetrometer test.

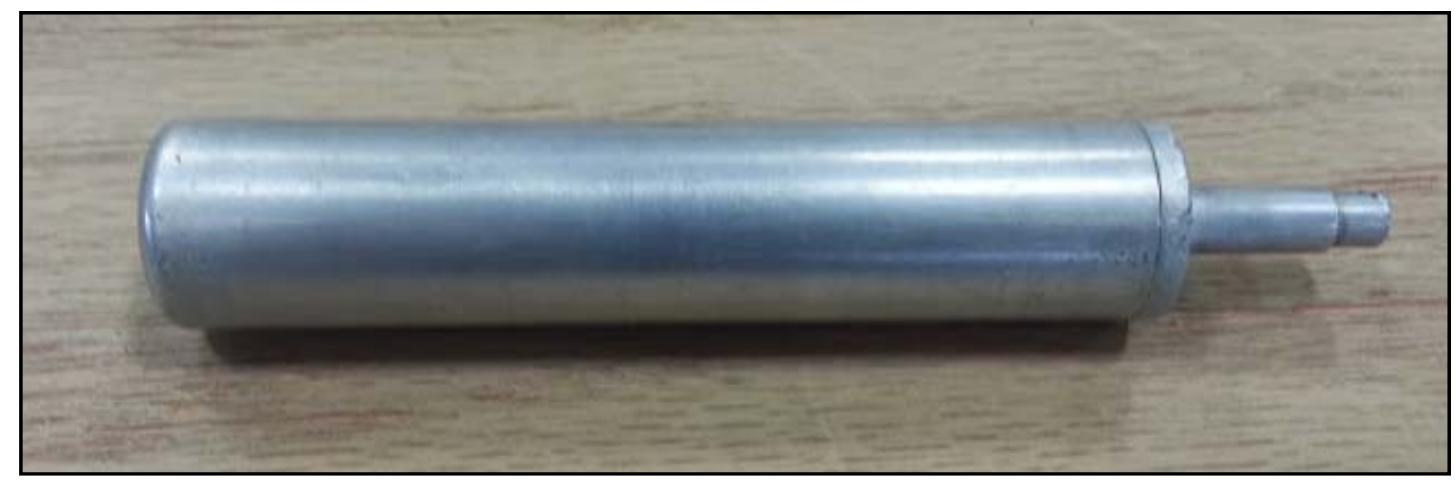

Figure 11: Pocket Penetrometer 


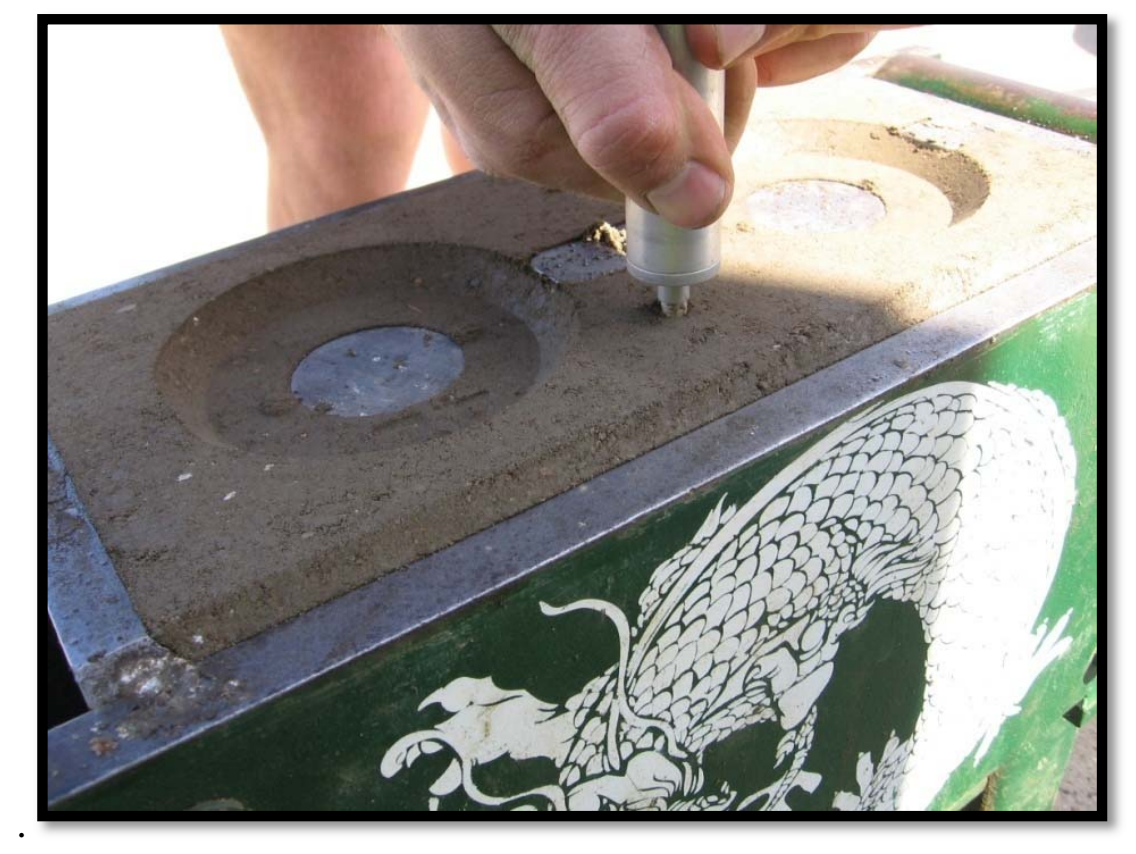

Figure 12: Penetrometer test of ICEB Units

\subsubsection{ICEB Unit Production}

Every mix batch produced 8 charges and each charge produced two half ICEB units, allowing for the manufacturing of 16 half units per mix. It was important to clean the interior of the press between batches so that the ICEB unit not to stick to the press. A light layer of lubricating oil was applied to the steel dividing plate to keep the ICEB unit from sticking to the press after extraction.

\subsubsection{Curing of ICEB Units}

ICEB units were immediately removed from the press and stacked upside down on a protected curing rack. All units were cured in a protected shed and watered twice within a 24-hour period. After a period of no less than 48 hours, the ICEB units were carefully 
stacked 8 units high and covered for humid curing. ICEB units were lightly watered daily for a period of 7 days and later carefully moved to the structural testing lab at Cal Poly for storage and construction.

\subsubsection{ICEB Unit Dimensions}

Due to differences of material content of each ICEB unit mix, the average dimensions of the weak, medium, and strong ICEB units varied slightly (Table 6 and Figure 13). The ICEB unit length $\left(l_{b}\right)$ and the side grout channel length $\left(l_{g}\right)$ had the greatest variance among all ICEB unit dimensions with coefficients of variance of $0.7 \%$ and $1.5 \%$, respectively. The variations of ICEB unit dimension between the weak, medium, and strong mixes may be caused by the variation of soil (clay) content of each mix. Earth blocks with higher clay content and lower cement proportions typically exhibit greater shrinkage after pressing (Walker and Stace, 1996). Furthermore, strong ICEB units weighed approximately $4 \%$ more than weak and medium ICEB units. The coefficient of variance of weight among all ICEB units was $2 \%$. 


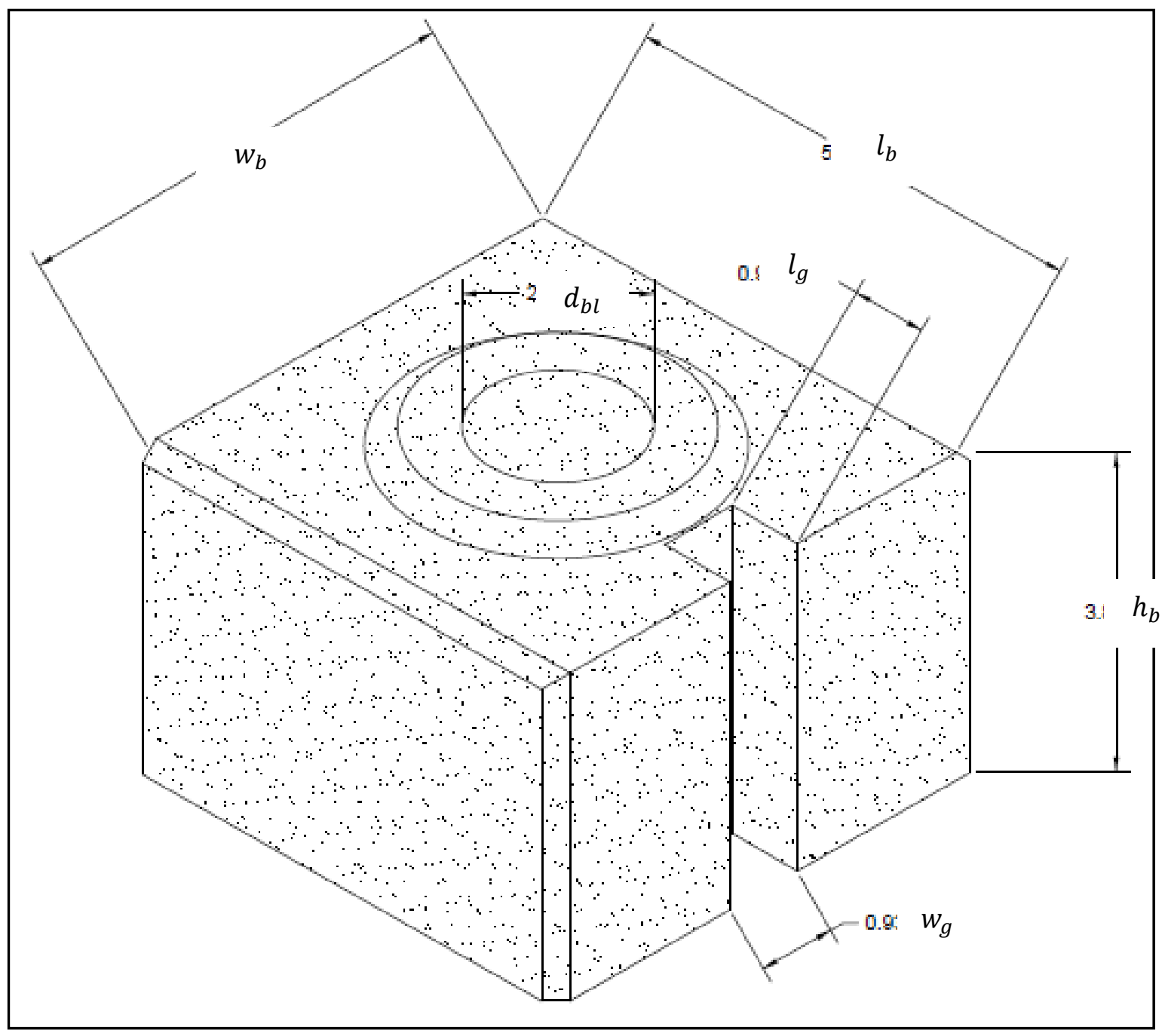

Figure 13: ICEB Unit Illustration

Table 6: Average ICEB Unit Dimensions and Weights

\begin{tabular}{|c|c|c|c|c|c|c|c|c|c|}
\hline \multirow{2}{*}{$\begin{array}{l}\text { ICEB } \\
\text { Type }\end{array}$} & \multirow{2}{*}{$\begin{array}{c}\text { Unit } \\
\text { Length } \\
\left(l_{b}\right)\end{array}$} & \multirow{2}{*}{$\begin{array}{c}\text { Unit } \\
\text { Width } \\
\left(w_{b}\right)\end{array}$} & \multirow{2}{*}{$\begin{array}{c}\text { Reinforceme } \\
\text { nt Hole } \\
\text { Diameter } \\
\left(d_{b l}\right) \\
\end{array}$} & \multirow{2}{*}{$\begin{array}{c}\text { Unit } \\
\text { Height } \\
\left(\boldsymbol{h}_{\boldsymbol{b}}\right)\end{array}$} & \multicolumn{2}{|c|}{$\begin{array}{c}\text { Side Grout Key } \\
\text { Channel }\end{array}$} & \multirow{2}{*}{$\begin{array}{l}\text { Gross } \\
\text { Area } \\
\left(\boldsymbol{A}_{g b}\right)\end{array}$} & \multirow{2}{*}{$\begin{array}{c}\text { Net Area } \\
\left(\boldsymbol{A}_{n b}\right)\end{array}$} & \multirow{2}{*}{$\begin{array}{c}\text { Average } \\
\text { Unit } \\
\text { Weight }\end{array}$} \\
\hline & & & & & $\begin{array}{c}\text { Length } \\
\left(l_{g}\right)\end{array}$ & $\begin{array}{l}\text { Width } \\
\left(w_{g}\right)\end{array}$ & & & \\
\hline Weak & $\begin{array}{l}146 \mathrm{~mm} \\
\text { (5.75 in) }\end{array}$ & $\begin{array}{l}148 \mathrm{~mm} \\
\text { (5.84 in) }\end{array}$ & $\begin{array}{l}\text { 44 mm } \\
\text { (1.73 in) }\end{array}$ & $\begin{array}{l}101 \mathrm{~mm} \\
\text { (3.97 in) }\end{array}$ & $\begin{array}{c}23 \mathrm{~mm} \\
\text { (0.91 in) }\end{array}$ & $\begin{array}{c}24 \mathrm{~mm} \\
\text { (0.94 in) }\end{array}$ & $\begin{array}{l}216.9 \mathrm{~cm}^{2} \\
\left(33.62 \mathrm{in}^{2}\right)\end{array}$ & $\begin{array}{l}196.2 \mathrm{~cm}^{2} \\
\left(30.42 \mathrm{in}^{2}\right)\end{array}$ & $\begin{array}{l}3701 \mathrm{~g} . \\
(8.16 \mathrm{lb})\end{array}$ \\
\hline Medium & $\begin{array}{l}148 \mathrm{~mm} \\
(5.81 \mathrm{in})\end{array}$ & $\begin{array}{l}149 \mathrm{~mm} \\
(5.87 \mathrm{in}) \\
\end{array}$ & $\begin{array}{c}44 \mathrm{~mm} \\
(1.73 \mathrm{in})\end{array}$ & $\begin{array}{l}101 \mathrm{~mm} \\
(3.96 \mathrm{in}) \\
\end{array}$ & $\begin{array}{c}22 \mathrm{~mm} \\
(0.88 \mathrm{in}) \\
\end{array}$ & $\begin{array}{c}24 \mathrm{~mm} \\
(0.95 \mathrm{in}) \\
\end{array}$ & $\begin{array}{l}220.0 \mathrm{~cm}^{2} \\
\left(34.1 \mathrm{in}^{2}\right) \\
\end{array}$ & $\begin{array}{l}199.4 \mathrm{~cm}^{2} \\
\left(30.91 \mathrm{in}^{2}\right) \\
\end{array}$ & $\begin{array}{l}3692 \mathrm{~g} . \\
(8.14 \mathrm{lb})\end{array}$ \\
\hline Strong & $\begin{array}{l}148 \mathrm{~mm} \\
\text { (5.83 in) }\end{array}$ & $\begin{array}{l}148 \mathrm{~mm} \\
(5.84 \mathrm{in})\end{array}$ & $\begin{array}{c}44 \mathrm{~mm} \\
(1.73 \mathrm{in})\end{array}$ & $\begin{array}{l}100 \mathrm{~mm} \\
(3.95 \mathrm{in})\end{array}$ & $\begin{array}{c}23 \mathrm{~mm} \\
(0.90 \mathrm{in})\end{array}$ & $\begin{array}{c}24 \mathrm{~mm} \\
(0.94 \mathrm{in}) \\
\end{array}$ & $\begin{array}{l}219.8 \mathrm{~cm}^{2} \\
\left(34.06 \mathrm{in}^{2}\right)\end{array}$ & $\begin{array}{l}199.1 \mathrm{~cm}^{2} \\
\left(30.86 \mathrm{in}^{2}\right)\end{array}$ & $\begin{array}{l}3829 \mathrm{~g} . \\
(8.44 \mathrm{lb})\end{array}$ \\
\hline $\begin{array}{c}\text { Coeffi- } \\
\text { cient of } \\
\text { Variance }\end{array}$ & $0.7 \%$ & $0.3 \%$ & $0.0 \%$ & $0.3 \%$ & $1.5 \%$ & $0.5 \%$ & $0.8 \%$ & $0.9 \%$ & $2 \%$ \\
\hline
\end{tabular}




\subsubsection{ICEB Unit Compressive Strength $\left(\boldsymbol{f}^{\prime}{ }_{\boldsymbol{b}}\right)$}

To ensure consistency among all ICEB units, a randomly selected single ICEB unit from every batch was tested for compressive strength. Single ICEB units were tested with the steel insert pressing plates used to form them so that bearing would be over the entire unit face (Figure 14). Two extensometers were attached with rubber bands on opposite sides on selected specimens. Weak, medium, and strong ICEB units were tested at rates of 0.06 in/min, $0.05 \mathrm{in} / \mathrm{min}$, and $0.04 \mathrm{in} / \mathrm{min}$, respectively.

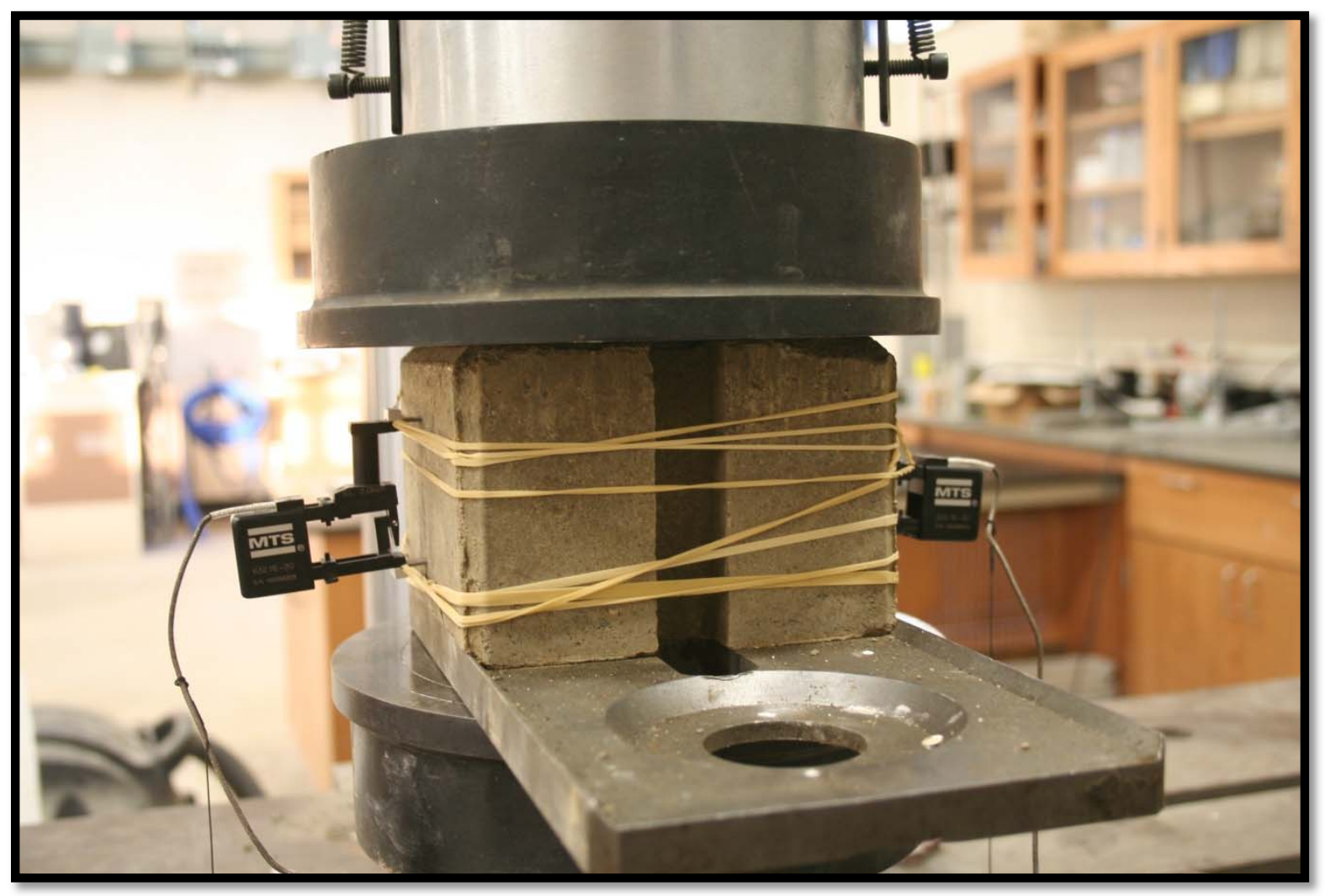

Figure 14: ICEB Unit Compression Test Set Up 


\subsubsection{Average ICEB Unit Compressive Strength $\left(\boldsymbol{f}^{\prime}{ }_{b}\right)$ and Quality Assurance of ICEB Batches}

The compressive strength between ICEB units can vary significantly. To track the quality and consistency of every press, a single ICEB unit from every batch was compressive tested until failure. The individual ICEB unit compressive batch strength $\left(f^{\prime}{ }_{b s}\right)$ of specimens was averaged to create the ICEB unit compressive strength $\left(f^{\prime}{ }_{b}\right)$ for weak, medium, and strong units (Table 7). There was higher compressive strength variance among ICEB units when specimens contained a high percentage of soil (clay) and a low percentage of cement. 
Table 7: ICEB Unit Compressive Batch Strength $\left(\boldsymbol{f}^{\prime}{ }_{b s}\right)$ and Average Compressive Strength of ICEB Units $\left(\boldsymbol{f}^{\prime}{ }_{b}\right)$

\begin{tabular}{|c|c|c|c|c|}
\hline & \multirow{2}{*}{$\begin{array}{c}\text { Batch } \\
\text { Number }\end{array}$} & \multicolumn{3}{|c|}{ ICEB Unit Type } \\
\hline & & Weak & Medium & Strong \\
\hline \multirow{11}{*}{$\begin{array}{c}\text { Individual } \\
\text { ICEB Unit } \\
\text { Compressive } \\
\text { Batch } \\
\text { Strength } \\
\left(\boldsymbol{f}^{\prime}{ }_{b s}\right)\end{array}$} & 1 & $\begin{array}{l}4.15 \mathrm{MPa} \\
(603 \mathrm{psi})^{1}\end{array}$ & $\begin{array}{l}9.72 \mathrm{MPa} \\
\text { (1411 psi) }\end{array}$ & $\begin{array}{l}12.02 \mathrm{MPa} \\
(1743 \mathrm{psi})^{1}\end{array}$ \\
\hline & 2 & $\begin{array}{l}3.02 \mathrm{MPa} \\
\text { (438 psi) }\end{array}$ & $\begin{array}{l}\text { 6.26 MPa } \\
(909 \mathrm{psi})^{1}\end{array}$ & $\begin{array}{l}11.6 \mathrm{MPa} \\
\text { (1682 psi) }\end{array}$ \\
\hline & 3 & $\begin{array}{l}\text { 4.36 MPa } \\
(632 \mathrm{psi})\end{array}$ & $\begin{array}{l}7.72 \mathrm{MPa} \\
\text { (1119 psi) }\end{array}$ & $\begin{array}{l}10.08 \mathrm{MPa} \\
(1462 \mathrm{psi})\end{array}$ \\
\hline & 4 & $\begin{array}{l}\text { 4.07 MPa } \\
\text { (591 psi) }\end{array}$ & $\begin{array}{c}7.7 \mathrm{MPa} \\
(1116 \mathrm{psi})^{1}\end{array}$ & $\begin{array}{l}11.84 \mathrm{MPa} \\
(1717 \mathrm{psi})\end{array}$ \\
\hline & 5 & $\begin{array}{l}4.20 \mathrm{MPa} \\
(610 \mathrm{psi})\end{array}$ & $\begin{array}{l}\text { 8.09 MPa } \\
(1174 \mathrm{psi})\end{array}$ & $\begin{array}{l}12.51 \mathrm{MPa} \\
(1815 \mathrm{psi})\end{array}$ \\
\hline & 6 & $\begin{array}{l}3.10 \mathrm{MPa} \\
(450 \mathrm{psi})^{1}\end{array}$ & $\begin{array}{l}\text { 8.97 MPa } \\
\text { (1300 psi) }\end{array}$ & $\begin{array}{l}11.51 \mathrm{MPa} \\
(1669 \mathrm{psi})^{1}\end{array}$ \\
\hline & 7 & $\begin{array}{c}2.74 \mathrm{MPa} \\
(397 \mathrm{psi})\end{array}$ & $\begin{array}{c}7.51 \mathrm{MPa} \\
\text { (1089 psi) }\end{array}$ & $\begin{array}{l}11.42 \mathrm{MPa} \\
(1656 \mathrm{psi})\end{array}$ \\
\hline & 8 & $\begin{array}{l}3.53 \mathrm{MPa} \\
\text { (512 psi) }\end{array}$ & $\begin{array}{l}7.53 \mathrm{MPa} \\
\text { (1092 psi) }\end{array}$ & $\begin{array}{l}10.32 \mathrm{MPa} \\
(1497 \mathrm{psi})^{1}\end{array}$ \\
\hline & 9 & $\begin{array}{l}3.79 \mathrm{MPa} \\
(550 \mathrm{psi})\end{array}$ & $\begin{array}{c}7.27 \mathrm{MPa} \\
(1054 \mathrm{psi})^{1}\end{array}$ & $\begin{array}{c}13.46 \mathrm{MPa} \\
(1952 \mathrm{psi})\end{array}$ \\
\hline & 10 & $\begin{array}{c}4.67 \mathrm{MPa} \\
(677.0 \mathrm{psi})^{1}\end{array}$ & $\begin{array}{c}\text { 7.8 MPa } \\
\text { (1130.7 psi) }\end{array}$ & $\mathrm{N} / \mathrm{A}^{2}$ \\
\hline & 11 & $\begin{array}{l}3.96 \mathrm{MPa} \\
\text { (573.9 psi) }\end{array}$ & $\begin{array}{c}\text { 7.34 MPa } \\
\text { (1065.1 psi) }\end{array}$ & $\mathrm{N} / \mathrm{A}^{2}$ \\
\hline \multicolumn{2}{|c|}{$\begin{array}{c}\text { Average Compressive } \\
\text { Strength }\left(f^{\prime}{ }_{b}\right)\end{array}$} & $\begin{array}{l}3.78 \mathrm{MPa} \\
\text { (548.4 psi) }\end{array}$ & $\begin{array}{c}7.81 \mathrm{MPa} \\
(1132.5 \mathrm{psi})\end{array}$ & $\begin{array}{c}11.64 \mathrm{MPa} \\
(1688.2 \mathrm{psi})\end{array}$ \\
\hline \multicolumn{2}{|c|}{ Standard Deviation } & $\begin{array}{l}0.61 \mathrm{MPa} \\
(88.7 \mathrm{psi})\end{array}$ & $\begin{array}{c}0.91 \mathrm{MPa} \\
\text { (131.3 psi) }\end{array}$ & $\begin{array}{c}1.03 \mathrm{MPa} \\
(149.5 \mathrm{psi})\end{array}$ \\
\hline \multicolumn{2}{|c|}{ Coefficient of Variance } & $16 \%$ & $12 \%$ & $9 \%$ \\
\hline
\end{tabular}

(1) Equipped with strain gauges during compressive testing

(2) $\mathrm{A} 10^{\text {th }}$ and $11^{\text {th }}$ batch were not required for strong ICEB units 


\subsubsection{Bland (2011) ICEB Unit Strength $\left(\boldsymbol{f}^{\prime}{ }_{\boldsymbol{b}}\right)$ Comparison}

The medium ICEB unit mix proportion used in this research was derived from the ICEB unit mix used in Bland (2011). The compressive strength of medium ICEB units $\left(f^{\prime}{ }_{b}\right)$ produced in this research was nearly identical to the average compressive strength of ICEB units $\left(f^{\prime}{ }_{b}\right)$ produced in Bland (2011) (Table 8).

Table 8: Bland (2011) vs. Tested ICEB Unit Compressive Strength $\left(\boldsymbol{f}^{\prime}{ }_{b}\right)$

\begin{tabular}{|c|c|c|c|}
\hline & $\begin{array}{l}\text { Bland (2011) } \\
\text { ICEB Unit }\end{array}$ & $\begin{array}{c}\text { Tested } \\
\text { Medium ICEB } \\
\text { Unit } \\
\end{array}$ & Percent Difference \\
\hline $\begin{array}{c}\text { Average } \\
\text { Strength }\left(\boldsymbol{f}^{\prime}{ }_{h}\right)\end{array}$ & $\begin{array}{l}7.57 \mathrm{MPa} \\
\text { (1098 psi) }\end{array}$ & $\begin{array}{l}\text { 7.81 MPa } \\
\text { (1133 psi) }\end{array}$ & $3 \%$ \\
\hline $\begin{array}{c}\text { Number of ICEB } \\
\text { Units Tested }\end{array}$ & 8 & 11 & \\
\hline $\begin{array}{l}\text { Standard } \\
\text { deviation }\end{array}$ & $\begin{array}{c}0.66 \mathrm{MPa} \\
(96 \mathrm{psi})\end{array}$ & $\begin{array}{l}0.91 \mathrm{MPa} \\
(131 \mathrm{psi})\end{array}$ & \\
\hline $\begin{array}{c}\text { Coefficient of } \\
\text { Variance }\end{array}$ & $9 \%$ & $12 \%$ & \\
\hline
\end{tabular}




\subsubsection{Compressive ICEB Unit Strength $\left(\boldsymbol{f}^{\prime}{ }_{b s}\right)$ vs. Temperature at Pressing $\left(\boldsymbol{T}_{p}\right)$}

The temperature at the time of mixing and ICEB unit pressing $\left(T_{p}\right)$ was recorded for every batch. The observed temperatures changes at the time of mixing and pressing $\left(\mathrm{T}_{\mathrm{p}}\right)$ did not affect the overall compressive strength of the ICEB unit $\left(\boldsymbol{f}_{\boldsymbol{b} \boldsymbol{s}}\right)$ (Figure 15).

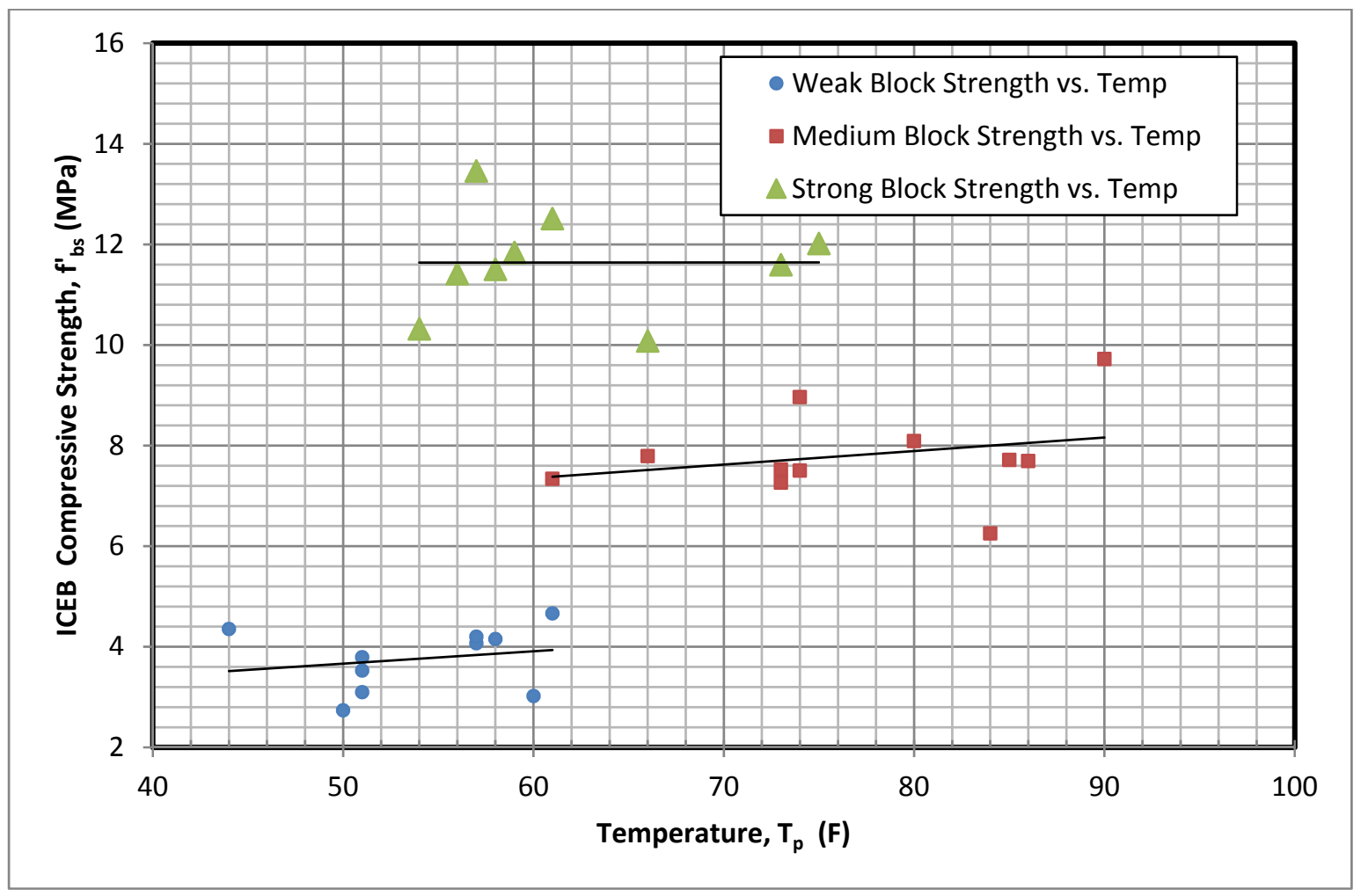

Figure 15: ICEB Unit Strength $\left(f^{\prime}{ }_{b s}\right)$ vs. Temperature at Pressing $\left(T_{p}\right)$ 


\subsubsection{Compressive ICEB Unit Strength $\left(\boldsymbol{f}^{\prime}{ }_{b s}\right)$ vs. Humidity at Pressing $\left(\boldsymbol{H}_{p}\right)$}

The humidity at the time of mixing and ICEB unit pressing $\left(\mathrm{H}_{\mathrm{p}}\right)$ was recorded for every batch. The observed humidity at the time of mixing and pressing $\left(\mathrm{H}_{\mathrm{p}}\right)$ did not appear to affect the compressive strength of the ICEB units $\left(f^{\prime}{ }_{b s}\right)$ (Figure 16).

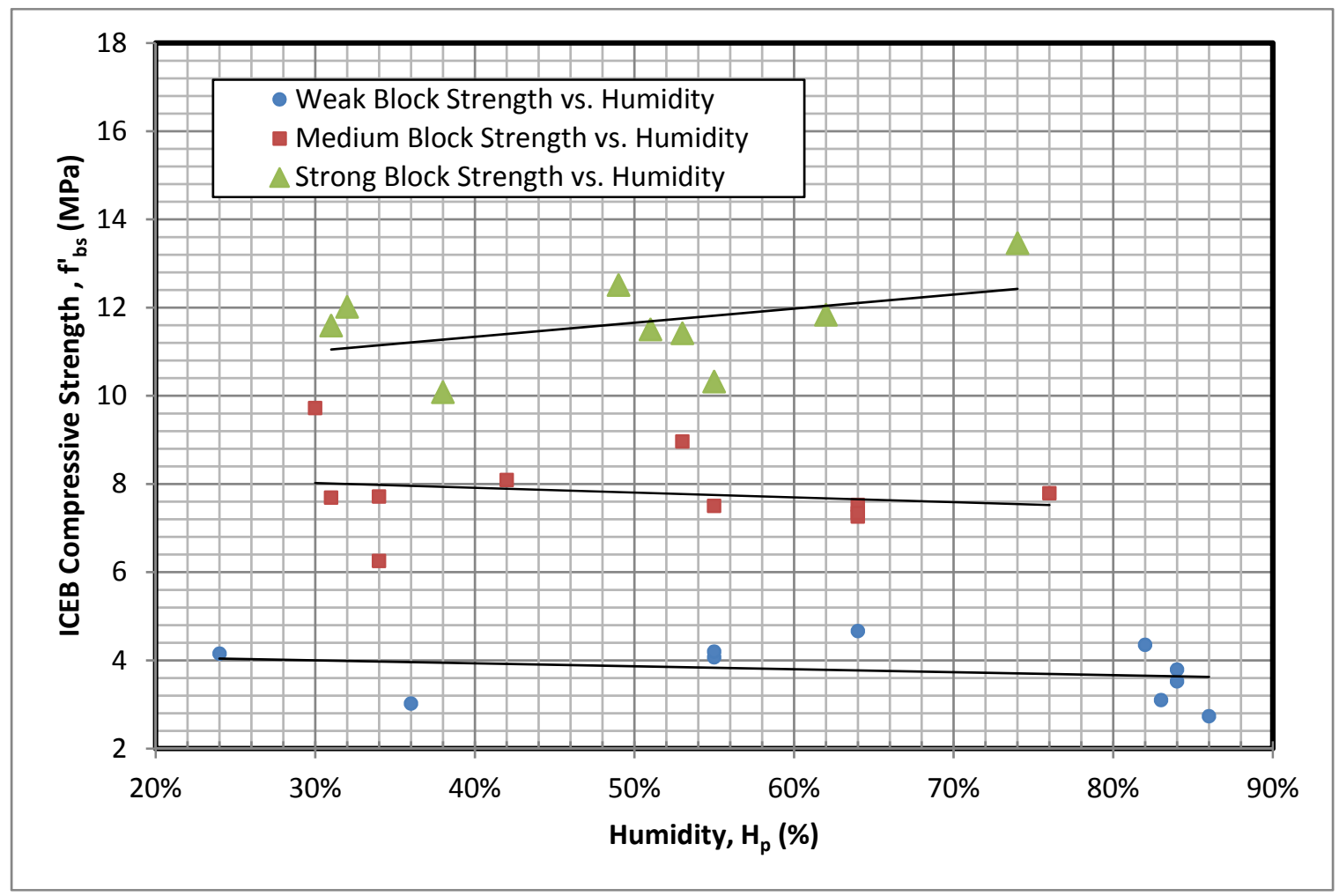

Figure 16: ICEB Unit Strength $\left(\boldsymbol{f}^{\prime}{ }_{b s}\right)$ vs. Humidity at Pressing $\left(\mathrm{H}_{\mathbf{p}}\right)$ 


\subsection{Grout Preparation and Sampling Methodology}

It was necessary to develop a grout with a high slump because of the small diameter of the ICEB unit grout holes. The installation of a lap splice further decreased the grouting area and exacerbated the need to develop a workable grout with a high fines content. Since ASTM Standard C1019-13 wasn’t suitable for grout of such low viscosity and of high flow rate, a suitable standard was developed to quantify workability. A 4-inch-long bottomless plastic cylinder with an inside diameter of 2 inches was filled with grout on a clean glass surface. Once filled, the cylinder was quickly removed which allowed the

grout to flow freely. Two opposite diameters were measured and averaged to determine the average grout flow diameter. All three grout strength mixtures developed in this research had the same workable flow of 8 inches.

\subsubsection{Grout vs. Non-Porous Grout}

The porous and dry nature of ICEB units lends to a high absorption rate of water away from the grout. This absorption can significantly change the strength of the grout. Two types of grout specimens were cast to determine how the water absorption of the ICEB unit would affect grout strength. The first type of grout specimen (defined simply as "grout" in this research) was cast inside an empty ICEB unit lined with a single layer of paper towel. This allowed water from the grout to be absorbed into the ICEB unit without a bond forming between the ICEB unit and the grout. Grout specimens were covered with plastic to minimize water loss to the atmosphere. The second type of grout specimen (defined as "non-porous grout" in this research) was cast into typical plastic cylinders 
molds ( 2 inches in diameter $\mathrm{x} 4$ inches in length) that limited water loss. These nonporous grout specimens were also covered with plastic to minimize additional water loss to the atmosphere. Non-porous grout specimens were weighed after casting to determine water loss, as discussed later in Section 3.5.9. All grout specimens were subjected to the same curing conditions as the grouted prisms and lap splice specimens. After curing for a minimum of 28 days, all grout specimens were removed from the ICEB units and plastic cylinders for sulfur capping.

\subsubsection{Targeted Grout Strengths}

Three grout mixes were developed to achieve three distinct grout compressive strengths. These three mixes are referred to as weak grout, medium grout, and strong grout. Prior ICEB research at Cal Poly had used lime as a fine additive in the mixing of grout. This research instead substituted soil for lime to increase the fines content of the grout. The soil used in the manufacturing of the grout was the same soil used in the creation of all ICEB units. Sand, soil, and cement proportions were varied to achieve various grout strengths. Weak strength grout was comprised only of soil and cement. Strong grout was comprised of only sand and cement. Medium grout was a combination of soil, sand, and cement. Grout was mixed in the proportions described in Table 9. 
Table 9: Grout Batch Mix Proportions

\begin{tabular}{|c|c|c|c|c|c|c|}
\hline \multirow{2}{*}{ Material } & \multicolumn{2}{|c|}{ Weak Grout } & \multicolumn{2}{c|}{ Medium Grout } & \multicolumn{2}{c|}{ Strong Grout } \\
\cline { 2 - 7 } & $\begin{array}{c}\text { Dry } \\
\text { Weight }\end{array}$ & $\begin{array}{c}\text { \% of } \\
\text { total }\end{array}$ & $\begin{array}{c}\text { Dry } \\
\text { Weight }\end{array}$ & $\begin{array}{c}\text { \% of } \\
\text { total }\end{array}$ & $\begin{array}{c}\text { Dry } \\
\text { Weight }\end{array}$ & $\begin{array}{c}\text { \% of } \\
\text { total }\end{array}$ \\
\hline Soil & $\begin{array}{c}10.3 \mathrm{~kg} \\
(22.7 \mathrm{lb})\end{array}$ & $57 \%$ & $\begin{array}{c}5.9 \mathrm{~kg} \\
(13.0 \mathrm{lb})\end{array}$ & $29 \%$ & $\begin{array}{c}0 \mathrm{~kg} \\
(0 \mathrm{lb})\end{array}$ & $0 \%$ \\
\hline Sand & $\begin{array}{c}0 \mathrm{~kg} \\
(0 \mathrm{lb})\end{array}$ & $0 \%$ & $\begin{array}{c}5.9 \mathrm{~kg} \\
(13.0 \mathrm{lb})\end{array}$ & $29 \%$ & $\begin{array}{c}13.0 \mathrm{~kg} \\
(28.7 \mathrm{lb})\end{array}$ & $62 \%$ \\
\hline Cement & $\begin{array}{c}1.6 \mathrm{~kg} \\
(3.5 \mathrm{lb})\end{array}$ & $9 \%$ & $\begin{array}{c}2.9 \mathrm{~kg} \\
(6.5 \mathrm{lb})\end{array}$ & $15 \%$ & $\begin{array}{c}3.5 \mathrm{~kg} \\
(7.7 \mathrm{lb})\end{array}$ & $17 \%$ \\
\hline Water & $\begin{array}{c}6.1 \mathrm{~kg} \\
(13.5 \mathrm{lb})\end{array}$ & $34 \%$ & $\begin{array}{c}5.3 \mathrm{~kg} \\
(11.7 \mathrm{lb})\end{array}$ & $27 \%$ & $\begin{array}{c}4.5 \mathrm{~kg} \\
(9.9 \mathrm{lb})\end{array}$ & $21 \%$ \\
\hline Total & $\begin{array}{c}18.0 \mathrm{~kg} \\
(39.7 \mathrm{lb})\end{array}$ & $100 \%$ & $\begin{array}{c}20.0 \mathrm{~kg} \\
(44.1 \mathrm{lb})\end{array}$ & $100 \%$ & $\begin{array}{c}21.0 \mathrm{~kg} \\
(46.3 \mathrm{lb})\end{array}$ & $100 \%$ \\
\hline
\end{tabular}

The casting of all grout, prism, and lap splice specimens required multiple grout batches due to the limited size of the available electric grout mixer. In order to have consistent grout for all specimens, individual batches were mixed in a small electric mixer and then poured into a lager container. The grout was constantly hand mixed to avoid particle settling. In total, four batches of weak strength grout, five batches of medium strength grout, and four batches of strong strength grout were used for all specimens. It took less than 2 hours from initial mixing to complete the grouting of all specimens for each grout type (weak, medium, strong).

\subsubsection{Grouting Stages of Grout Specimens, Prisms, and Lap Splice Specimens}

All grout specimens were cast at the same time as the prism and lap splice specimens. Grouting was sequenced into the following three stages:

Stage 1. Bottom three and a half ICEB units of lap splice grouted. First grout and non-porous grout specimens cast. First three prisms grouted. 
Stage 2. Middle four ICEB units of lap splice grouted (if required). Second nonporous grout specimens cast. Second three prisms grouted.

Stage 3. Top four ICEB units of lap splice specimens grouted (if required). Third grout and third non-porous grout specimens cast. Third three prisms grouted.

As is common practice with ICEBs, grouting was completed no more than four ICEB units at a time. During the stage one pour, the first three and half blocks were grouted to ensure a cold joint wasn’t present at the block boundaries.

\subsubsection{Grout Testing Matrix and Specimen Name Designation}

As discussed earlier in Section 3.4.1, each of the three ICEB unit types used in this research (weak, medium, and strong) had varying proportions of soil, sand, and cement. Due to the proportion differences of these materials, it was unknown if each ICEB unit type would absorb water from the grout at different rates, thus influencing the overall compressive strength of the grout. To determine whether a grout specimen cast in a particular ICEB unit type affected grout strength, grout specimens were cast into each ICEB unit type for curing. This produced a total of 6 grout specimens per grout type (weak, medium, strong). Specimens were named in order of stage cast $(1,2,3)$, type of grout (W, M, S), and type of ICEB unit it was cast in (W, M, S). For example, a medium grout specimen cast in a strong ICEB unit during the stage three pour has a name of 3MS. Table 10 provides a summary of grout specimens tested for compressive strength. The average grout compressive strength $\left(f^{\prime}{ }_{g}\right)$ is summarized in Section 3.5.12. 
Table 10: Grouting Schedule and Specimen Names

\begin{tabular}{|c|c|c|c|c|}
\cline { 2 - 5 } \multicolumn{1}{c|}{} & $\begin{array}{c}\text { Cast in Weak } \\
\text { ICEB Unit }\end{array}$ & $\begin{array}{c}\text { Cast in } \\
\text { Medium } \\
\text { ICEB Unit }\end{array}$ & $\begin{array}{c}\text { Cast in } \\
\text { Strong ICEB } \\
\text { Unit }\end{array}$ & $\begin{array}{c}\text { Total Number } \\
\text { of Grout } \\
\text { Specimens }\end{array}$ \\
\hline Weak Grout & $\begin{array}{c}\text { 2 Specimens } \\
(1 \mathrm{WW}, 3 W W)\end{array}$ & $\begin{array}{c}\text { 2 Specimens } \\
(1 \mathrm{MW}, 3 \mathrm{MW})\end{array}$ & $\begin{array}{c}\text { 2 Specimens } \\
(1 \mathrm{SW}, 3 S W)\end{array}$ & 6 \\
\hline Medium Grout & $\begin{array}{c}\text { 2 Specimens } \\
(1 \mathrm{WM}, 3 \mathrm{WM})\end{array}$ & $\begin{array}{c}\text { 2 Specimens } \\
(1 \mathrm{MM}, 3 \mathrm{MM})\end{array}$ & $\begin{array}{c}\text { 2 Specimens } \\
(1 \mathrm{SM}, 3 \mathrm{SM})\end{array}$ & 6 \\
\hline Strong Grout & $\begin{array}{c}\text { 2 Specimens } \\
(1 \mathrm{WS}, 3 \mathrm{WS})\end{array}$ & $\begin{array}{c}\text { 2 Specimens } \\
(1 \mathrm{MS}, 3 \mathrm{MS})\end{array}$ & $\begin{array}{c}\text { 2 Specimens } \\
(1 \mathrm{SS}, 3 S S)\end{array}$ & 6 \\
\hline
\end{tabular}

\subsubsection{Non-Porous Grout Testing Matrix and Specimen Name Designation}

Grout was also cast into 2-inch plastic cylinders to determine the strength of grout without the effects of ICEB water absorption. Two specimens were cast at grouting stages 1, 2, and 3 for each grout type (W, M, and S). Specimens were named in the order of the grout staged cast $(1,2,3)$, type of grout used (W, M, S), and overall number it was cast (1-6). Specimen 1W1 was not tested due to damaged caused during extraction of the specimen. Weak, non-porous grout specimens tended to be very fragile and were handled and tested with caution. Table 11 provides a summary of non-porous grout specimens tested for compressive strength $\left(f^{\prime}{ }_{n g}\right)$.

Table 11: Non-Porous Grouting Schedule

\begin{tabular}{|c|c|c|c|c|}
\cline { 2 - 4 } \multicolumn{1}{c|}{} & \multicolumn{3}{c|}{ Non-Porous Grout } & \multirow{2}{*}{$\begin{array}{c}\text { Total Number of } \\
\text { Grout Specimens }\end{array}$} \\
\cline { 2 - 4 } \multicolumn{1}{c|}{} & $\begin{array}{c}\text { Stage One } \\
\text { Pour }\end{array}$ & $\begin{array}{c}\text { Stage Two } \\
\text { Pour }\end{array}$ & $\begin{array}{c}\text { Stage } \\
\text { Three Pour }\end{array}$ & \\
\hline Weak Grout & $\begin{array}{c}\text { 1 Specimen } \\
\left(1 \mathrm{~W} 1^{1}, 1 \mathrm{~W} 2\right)\end{array}$ & $\begin{array}{c}\text { 2 Specimens } \\
(2 \mathrm{~W} 3,2 \mathrm{~W} 4)\end{array}$ & $\begin{array}{c}\text { 2 Specimens } \\
(3 \mathrm{~W} 5,3 \mathrm{~W} 6)\end{array}$ & 5 \\
\hline Medium Grout & $\begin{array}{c}\text { 2 Specimens } \\
(1 \mathrm{M} 1,1 \mathrm{M} 2)\end{array}$ & $\begin{array}{c}\text { 2 Specimens } \\
(2 \mathrm{M} 3,2 \mathrm{M} 4)\end{array}$ & $\begin{array}{c}\text { 2 Specimens } \\
(3 \mathrm{M} 5,3 \mathrm{M} 6)\end{array}$ & 6 \\
\hline Strong Grout & $\begin{array}{c}\text { 2 Specimens } \\
(1 \mathrm{~S} 1,1 \mathrm{~S} 2)\end{array}$ & $\begin{array}{c}\text { 2 Specimens } \\
(2 \mathrm{~S} 3,2 \mathrm{~S} 4)\end{array}$ & $\begin{array}{c}\text { 2 Specimens } \\
(3 \mathrm{~S} 5,3 \mathrm{~S} 6)\end{array}$ & 6 \\
\hline
\end{tabular}

(1) Specimen $1 \mathrm{~W} 1$ was not tested due to damaged caused during extraction of the specimen. 


\subsubsection{Grout Sulfur Capping}

After the grout had cured for more than 28 days, the specimens were carefully removed for sulfur capping in accordance with ASTM C-39.

\subsubsection{Grout Testing}

All grout was tested after the grout was allowed to cure at least four weeks. All grout specimens were tested in $+/-1$ day of the prisms and lap splice tests.

\subsubsection{Non-Porous Grout and Grout Specimen Aspect Ratio and Dimensions}

Non-porous grout specimens were cast in 101.6 mm (4 inch) high, 50.8 mm (2 inch) diameter plastic cylinders and effectively retained the same diameter after curing. The height of specimens slightly decreased after curing, likely due to bleeding (solids settling) and water evaporation (Table 12).

Table 12: Non- Porous Grout Specimen Dimensions

\begin{tabular}{|c|c|c|c|}
\hline Grout Type & $\begin{array}{c}\text { Average } \\
\text { Height } \\
\left(\boldsymbol{h}_{\boldsymbol{g}}\right)\end{array}$ & $\begin{array}{c}\text { Average } \\
\text { Diameter } \\
\left(\boldsymbol{d}_{\boldsymbol{g}}\right)\end{array}$ & $\begin{array}{c}\text { Average } \\
\text { Area } \\
\left(\boldsymbol{A}_{\boldsymbol{g r}}\right)\end{array}$ \\
\hline Non-Porous Weak & $\begin{array}{c}100.6 \mathrm{~mm} \\
(4.0 \mathrm{in})\end{array}$ & $\begin{array}{c}50.8 \mathrm{~mm} \\
(2 \mathrm{in})\end{array}$ & $\begin{array}{c}2024 \mathrm{~mm}^{2} \\
\left(3.1 \mathrm{in}^{2}\right)\end{array}$ \\
\hline $\begin{array}{c}\text { Non-Porous } \\
\text { Medium }\end{array}$ & $\begin{array}{c}98.2 \mathrm{~mm} \\
(3.9 \mathrm{in})\end{array}$ & $\begin{array}{c}50.7 \mathrm{~mm} \\
(2 \mathrm{in})\end{array}$ & $\begin{array}{c}2017 \mathrm{~mm}^{2} \\
\left(3.1 \mathrm{in}^{2}\right)\end{array}$ \\
\hline $\begin{array}{c}\text { Non-Porous } \\
\text { Strong }\end{array}$ & $\begin{array}{c}95.6 \mathrm{~mm} \\
(3.8 \mathrm{in})\end{array}$ & $\begin{array}{c}50.7 \mathrm{~mm} \\
(2 \mathrm{in})\end{array}$ & $\begin{array}{c}2022 \mathrm{~mm}^{2} \\
\left(3.1 \mathrm{in}^{2}\right)\end{array}$ \\
\hline $\begin{array}{c}\text { Coefficient of } \\
\text { Variance }\end{array}$ & $2.6 \%$ & $0.1 \%$ & $0.2 \%$ \\
\hline
\end{tabular}

Grout specimens cast in ICEB units were more slender than their non-porous counterparts formed in plastic cylinders. The average diameter of the ICEB reinforcement hole was 
measured at $43.9 \mathrm{~mm}$ (1.73 in), slightly less than the $50.8 \mathrm{~mm}$ (2 inch) diameter of the plastic cylinder. The temporary paper towel wrapped around the inside of the ICEB reinforcement hole also led to a reduction in the diameter of the grout specimen (Table 13).

Table 13: Grout Specimen Dimensions

\begin{tabular}{|c|c|c|c|}
\hline Grout Type & $\begin{array}{c}\text { Average } \\
\text { Height } \\
\left(h_{g}\right)\end{array}$ & $\begin{array}{c}\text { Average } \\
\text { Diameter } \\
\left(d_{g}\right)\end{array}$ & $\begin{array}{c}\text { Average } \\
\text { Area } \\
\left(A_{g r}\right)\end{array}$ \\
\hline Weak & $\begin{array}{c}100.0 \mathrm{~mm} \\
(3.9 \mathrm{in})\end{array}$ & $\begin{array}{c}40.6 \mathrm{~mm} \\
(1.6 \mathrm{in})\end{array}$ & $\begin{array}{c}1295 \mathrm{~mm}^{2} \\
\left(2.01 \mathrm{in}^{2}\right)\end{array}$ \\
\hline Medium & $\begin{array}{c}106.9 \mathrm{~mm} \\
(4.21 \mathrm{in})\end{array}$ & $\begin{array}{c}39.2 \mathrm{~mm} \\
(1.54 \mathrm{in})\end{array}$ & $\begin{array}{c}1207 \mathrm{~mm}^{2} \\
\left(1.87 \mathrm{in}^{2}\right)\end{array}$ \\
\hline Strong & $\begin{array}{c}105.5 \mathrm{~mm} \\
(4.16 \mathrm{in})\end{array}$ & $\begin{array}{c}42.0 \mathrm{~mm} \\
(1.65 \mathrm{in})\end{array}$ & $\begin{array}{c}1387 \mathrm{~mm}^{2} \\
\left(2.15 \mathrm{in}^{2}\right)\end{array}$ \\
\hline $\begin{array}{c}\text { Coefficient of } \\
\text { Variance }\end{array}$ & $3.5 \%$ & $3.5 \%$ & $7.0 \%$ \\
\hline
\end{tabular}

\subsubsection{Non-Porous Grout Water Loss}

Non-porous grout specimens were weighed immediately after grouting and again before compressive testing. Specimens comprised from mix proportions of low cement and high soil content lost less water during curing (Table 14).

Table 14: Water loss of Non-Porous Grout

\begin{tabular}{|c|c|c|c|}
\hline $\begin{array}{c}\text { Grout } \\
\text { Type }\end{array}$ & $\begin{array}{c}\text { Average Initial } \\
\text { Weight of Cast } \\
\text { Grout }\end{array}$ & $\begin{array}{c}\text { Average } \\
\text { Weight of } \\
\text { Cured Grout }\end{array}$ & \% difference \\
\hline Weak & $\begin{array}{c}354.5 \mathrm{~g} . \\
(0.78 \mathrm{lb})\end{array}$ & $\begin{array}{c}352.6 \mathrm{~g} . \\
(0.78 \mathrm{lb})\end{array}$ & $0.5 \%$ \\
\hline Medium & $\begin{array}{c}386.0 \mathrm{~g} . \\
(0.85 \mathrm{lb})\end{array}$ & $\begin{array}{c}379.6 \mathrm{~g} . \\
(0.84 \mathrm{lb})\end{array}$ & $1.7 \%$ \\
\hline Strong & $\begin{array}{c}422.7 \mathrm{~g} . \\
(0.93 \mathrm{lb})\end{array}$ & $\begin{array}{l}410.3 \mathrm{~g} . \\
(0.90 \mathrm{lb})\end{array}$ & $3.0 \%$ \\
\hline
\end{tabular}




\subsubsection{Grout Specimen Instrumentation}

Randomly selected specimens from each grout type were equipped with two strain extensometers on opposite sides to achieve a strain reading as shown below in Figure 17.
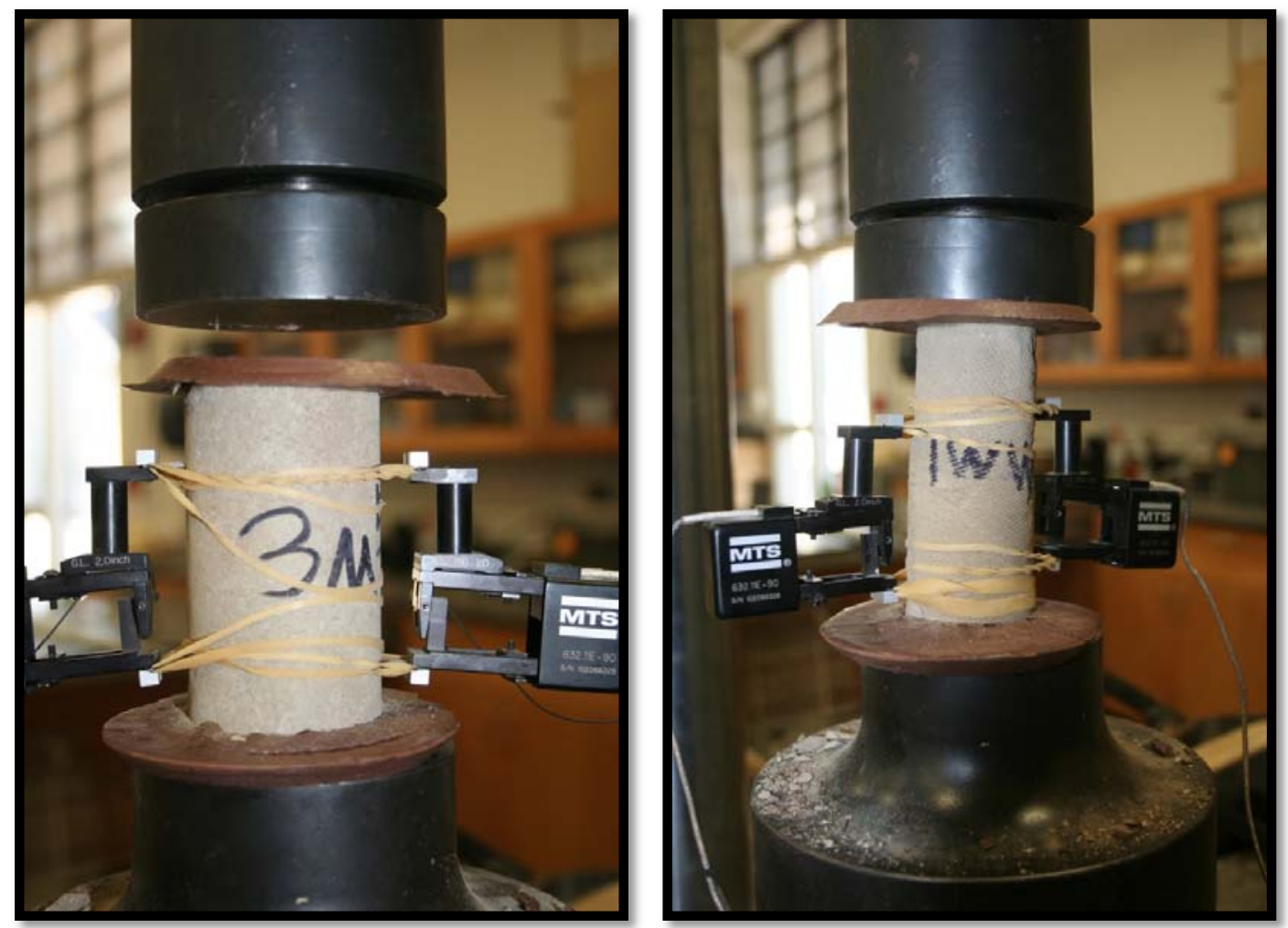

Figure 17: Non-Porous Weak Grout Specimen (left) and Medium Grout Specimen (right) Test Set Up and Instrumentation

\subsubsection{Test Machine and Specimen Loading Rate}

All grout specimens were compressive tested in the Cal Poly Civil Engineering lab, on the same machine used to test all prism and lap splice specimens. All grout specimens were tested at a loading rate of $0.02 \mathrm{in} / \mathrm{min}$. 


\subsubsection{Grout vs. Non-Porous Grout Strength}

Grout specimens were considerably stronger than their non-porous grout equivalents. Moreover, there was a larger percent difference in compressive strength between grout and non-porous grout specimens that contained a high percentage of soil and a low percentage of cement (Table 15). These findings are commensurate with the findings in previous Cal Poly ICEB research.

Table 15: Average Grout and Non-Porous Grout Compressive Strength

\begin{tabular}{|c|c|c|c|}
\hline Grout Type & $\begin{array}{c}\text { Average Grout } \\
\text { Strength } \\
\left(\boldsymbol{f}^{\prime}{ }_{\boldsymbol{g}}\right)\end{array}$ & $\begin{array}{c}\text { Average Non- } \\
\text { Porous Grout } \\
\text { Strength } \\
\left(\boldsymbol{f}^{\prime}{ }_{\boldsymbol{n}}\right)\end{array}$ & $\begin{array}{c}\text { Percent } \\
\text { Difference }\end{array}$ \\
\hline Weak Grout & $\begin{array}{c}1.35 \mathrm{MPa} \\
(195 \mathrm{psi})\end{array}$ & $\begin{array}{c}0.43 \mathrm{MPa} \\
(62 \mathrm{psi})\end{array}$ & $104 \%$ \\
\hline $\begin{array}{c}\text { Medium } \\
\text { Grout }\end{array}$ & $\begin{array}{c}7.47 \mathrm{MPa} \\
(1084 \mathrm{psi})\end{array}$ & $\begin{array}{c}3.28 \mathrm{MPa} \\
(476 \mathrm{psi})\end{array}$ & $78 \%$ \\
\hline Strong Grout & $\begin{array}{c}15.50 \mathrm{MPa} \\
(2248.4 \mathrm{psi})\end{array}$ & $\begin{array}{c}13.88 \mathrm{MPa} \\
(2013 \mathrm{psi})\end{array}$ & $11 \%$ \\
\hline
\end{tabular}

For the purposes of this research, the non-porous grout strength data $\left(f^{\prime}{ }_{n g}\right)$ was used for comparison and quality control purposes. It was not used in the data analysis section of this paper. All subsequent calculations reflecting the use of grout strength are in reference to the grout strength $\left(f_{g}^{\prime}\right)$ and not the non-porous grout strength $\left(f^{\prime}{ }_{n g}\right)$. Due to the highwater absorption of ICEB units, the grout strength $\left(f^{\prime}{ }_{g}\right)$ is a more accurate representation of the actual grout strength used in lap splice and prism specimens. 


\subsubsection{Grout Compressive Strength $\left(\boldsymbol{f}_{\boldsymbol{g}}^{\prime}\right)$ vs. Soil Content, Cement Content}

Grout mixes that contained high percentages of soil (clay) by volume produced grout specimens with lower compressive strengths. Grout mixes that contained high percentages of cement by volume produced grout specimens that had higher compressive strengths. Findings are consistent with conclusions from Walker and Stace (2008) where compressive strength is improved by increasing cement content and impaired by increasing soil (clay) content.

\subsubsection{Grout Strength $\left(\boldsymbol{f}^{\prime}{ }_{g}\right)$ vs. ICEB Unit Cure Type}

There was no significant correlation between grout strength $\left(f^{\prime} g\right)$ and the type of ICEB unit in which the grout was cast (Table 16). The ICEB unit type (W, M, and S) did not affect the strength of the grout $\left(f^{\prime} g\right)$. There was higher strength variability among grout specimens when specimens contained a high percentage of soil and a low percentage of cement by volume.

Table 16: Grout Strength $\left(\boldsymbol{f}^{\prime}{ }_{g}\right)$ vs. ICEB Unit Cast Type (W, M, S)

\begin{tabular}{|c|c|c|c|c|c|c|}
\hline $\begin{array}{l}\text { Grout } \\
\text { Type }\end{array}$ & $\begin{array}{l}\text { Cured in } \\
\text { Weak } \\
\text { ICEB Unit } \\
\end{array}$ & $\begin{array}{l}\text { Cured in } \\
\text { Medium } \\
\text { ICEB Unit }\end{array}$ & $\begin{array}{c}\text { Cured in } \\
\text { Strong ICEB } \\
\text { Unit } \\
\end{array}$ & $\begin{array}{c}\text { Average } \\
\text { Compressive } \\
\text { Strength } \\
\end{array}$ & $\begin{array}{l}\text { Standard } \\
\text { Deviation }\end{array}$ & COV \\
\hline $\begin{array}{l}\text { Weak } \\
\text { Grout }\end{array}$ & $\begin{array}{l}1.56 \mathrm{MPa} \\
\text { (227 psi) }\end{array}$ & $\begin{array}{c}1.32 \mathrm{MPa} \\
(191 \mathrm{psi})\end{array}$ & $\begin{array}{c}1.16 \mathrm{MPa} \\
\text { (168 psi) }\end{array}$ & $\begin{array}{l}1.35 \mathrm{MPa} \\
(195 \mathrm{psi})\end{array}$ & $\begin{array}{c}0.20 \mathrm{MPa} \\
(30 \mathrm{psi})\end{array}$ & $15.2 \%$ \\
\hline $\begin{array}{c}\text { Medium } \\
\text { Grout }\end{array}$ & $\begin{array}{l}6.39 \mathrm{MPa} \\
\text { (927 psi) }\end{array}$ & $\begin{array}{l}\text { 8.59 MPa } \\
\text { (1245 psi) }\end{array}$ & $\begin{array}{l}7.44 \mathrm{MPa} \\
\text { (1078 psi) }\end{array}$ & $\begin{array}{l}7.47 \mathrm{MPa} \\
(1084 \mathrm{psi})\end{array}$ & $\begin{array}{l}1.10 \mathrm{MPa} \\
\text { (159 psi) }\end{array}$ & $14.7 \%$ \\
\hline $\begin{array}{l}\text { Strong } \\
\text { Grout }\end{array}$ & $\begin{array}{l}15.20 \mathrm{MPa} \\
(2204 \mathrm{psi})\end{array}$ & $\begin{array}{l}14.89 \mathrm{MPa} \\
(2160 \mathrm{psi})\end{array}$ & $\begin{array}{l}16.42 \mathrm{MPa} \\
(2381 \mathrm{psi})\end{array}$ & $\begin{array}{l}15.5 \mathrm{MPa} \\
\text { (2248 psi) }\end{array}$ & $\begin{array}{c}0.81 \mathrm{MPa} \\
\text { (117 psi) }\end{array}$ & $5.2 \%$ \\
\hline
\end{tabular}




\subsubsection{Non-Porous Compressive Grout Strength $\left(\boldsymbol{f}_{p g}^{\prime}\right)$ vs. Grouting Stage (I, II, III)}

Grout specimens were collected over all three grouting stages to determine if there was a correlation between the grout compressive strength $\left(f^{\prime}{ }_{p g}\right)$ and the time the grout was cast. No discernable correlation was observed between non-porous compressive strength vs. grouting stage (Table 17).

Table 17: Non-Porous Grout Strength $\left(\boldsymbol{f}^{\prime}{ }_{p g}\right)$ vs. Grouting Stage (I, II, III)

\begin{tabular}{|c|c|c|c|c|}
\hline Grout Type & $\begin{array}{c}\text { Stage One } \\
\text { Pour }\end{array}$ & $\begin{array}{c}\text { Stage Two } \\
\text { Pour }\end{array}$ & $\begin{array}{c}\text { Stage Three } \\
\text { Pour }\end{array}$ & $\begin{array}{c}\text { Coefficient of } \\
\text { Variance }\end{array}$ \\
\hline Weak Grout & $\begin{array}{c}0.47 \mathrm{MPa} \\
(69 \mathrm{psi})\end{array}$ & $\begin{array}{c}0.41 \mathrm{MPa} \\
(59 \mathrm{psi})\end{array}$ & $\begin{array}{c}0.42 \mathrm{MPa} \\
(62 \mathrm{psi})\end{array}$ & $8.0 \%$ \\
\hline Medium Grout & $\begin{array}{c}3.09 \mathrm{MPa} \\
(449 \mathrm{psi})\end{array}$ & $\begin{array}{c}3.15 \mathrm{MPa} \\
(457 \mathrm{psi})\end{array}$ & $\begin{array}{c}3.61 \mathrm{MPa} \\
(523 \mathrm{psi})\end{array}$ & $8.6 \%$ \\
\hline Strong Grout & $\begin{array}{c}14.59 \mathrm{MPa} \\
(2116 \mathrm{psi})\end{array}$ & $\begin{array}{c}12.98 \mathrm{MPa} \\
(1883 \mathrm{psi})\end{array}$ & $\begin{array}{c}14.06 \mathrm{MPa} \\
(2039 \mathrm{psi})\end{array}$ & $5.9 \%$ \\
\hline
\end{tabular}

Furthermore, no significant correlation was observed for grout compressive strength $\left(f^{\prime} g\right)$ vs. grouting stage (I, III) (Table 18).

Table 18: Non-Porous Grout Strength $\left(\boldsymbol{f}^{\prime} \boldsymbol{g}\right)$ vs. Grouting Stage (I, III)

\begin{tabular}{|c|c|c|c|}
\hline Grout Type & $\begin{array}{c}\text { Stage One } \\
\text { Pour }\end{array}$ & $\begin{array}{c}\text { Stage } \\
\text { Three } \\
\text { Pour }\end{array}$ & $\begin{array}{c}\text { Coefficient of } \\
\text { Variance }\end{array}$ \\
\hline Weak Grout & $\begin{array}{c}1.35 \mathrm{MPa} \\
(196 \mathrm{psi})\end{array}$ & $\begin{array}{c}1.34 \mathrm{MPa} \\
(195 \mathrm{psi})\end{array}$ & $0.2 \%$ \\
\hline Medium Grout & $\begin{array}{c}7.88 \mathrm{MPa} \\
(1143 \mathrm{psi})\end{array}$ & $\begin{array}{c}7.06 \mathrm{MPa} \\
(1025 \mathrm{psi})\end{array}$ & $7.7 \%$ \\
\hline Strong Grout & $\begin{array}{c}15.80 \mathrm{MPa} \\
(2292 \mathrm{psi})\end{array}$ & $\begin{array}{c}15.20 \mathrm{MPa} \\
(2205 \mathrm{psi})\end{array}$ & $2.8 \%$ \\
\hline
\end{tabular}




\subsection{Average Curing Temperature and Humidity}

The average indoor temperature and humidity over the entire duration of curing (from mixing to testing) of all grout specimens, prisms, and lap splice specimens was $65^{\circ} \mathrm{F}$ with 55\% humidity (Table 19). The temperature and humidity was recorded once a day at random times. All specimens were assembled, grouted, cured, and tested within the Civil Engineering Lab at Cal Poly.

Table 19: Average Curing Temperature and Humidity

\begin{tabular}{|c|c|c|}
\cline { 2 - 3 } \multicolumn{1}{c|}{} & Temperature ( $\left.{ }^{\circ} \mathbf{F}\right)$ & Humidity \\
\hline Min & 62 & $45 \%$ \\
\hline Mean & 65 & $55 \%$ \\
\hline Max & 68 & $69 \%$ \\
\hline
\end{tabular}

\subsection{Specified Compressive Strength of Masonry $\left(\boldsymbol{f}^{\prime}{ }_{m}\right)$}

The specified compressive strength of masonry $\left(f^{\prime}{ }_{m}\right)$ is the essential performance value used in the design of masonry structures and is defined as the maximum compressive force resisted per unit of net cross sectional area of masonry. Per ASTM C1314, the compressive strength of masonry $\left(f^{\prime}{ }_{m}\right)$ can be obtained by performing compressive tests on capped masonry prisms. Prisms are constructed out of an assemblage of three stacked and fully grouted masonry unit.

\subsubsection{ICEB Prism Construction}

Per ASTM Standard C1314, all prism specimens were stacked three ICEB units high and fully grouted in sequence as described in Section 3.5.3. Prisms were covered in plastic 
and kept next to lap splice specimens and grout specimens to ensure consistent curing conditions across all specimens. All fully grouted prisms were allowed to cure for at least 28 days.

\subsubsection{ICEB Prism Testing Matrix}

Three distinct grout strengths (weak, medium, and strong) and three distinct ICEB unit strengths (weak, medium, and strong) were combined to create nine unique prism strengths (Table 20). Three prism specimens were constructed for all nine unique prism strengths for a total 27 prism specimens. For comparison purposes, two un-grouted prism specimens were constructed for all ICEB unit strengths (weak, medium, strong) for a total of 6 un-grouted specimens.

Table 20: Prism Testing Matrix and Specimen Name Designation

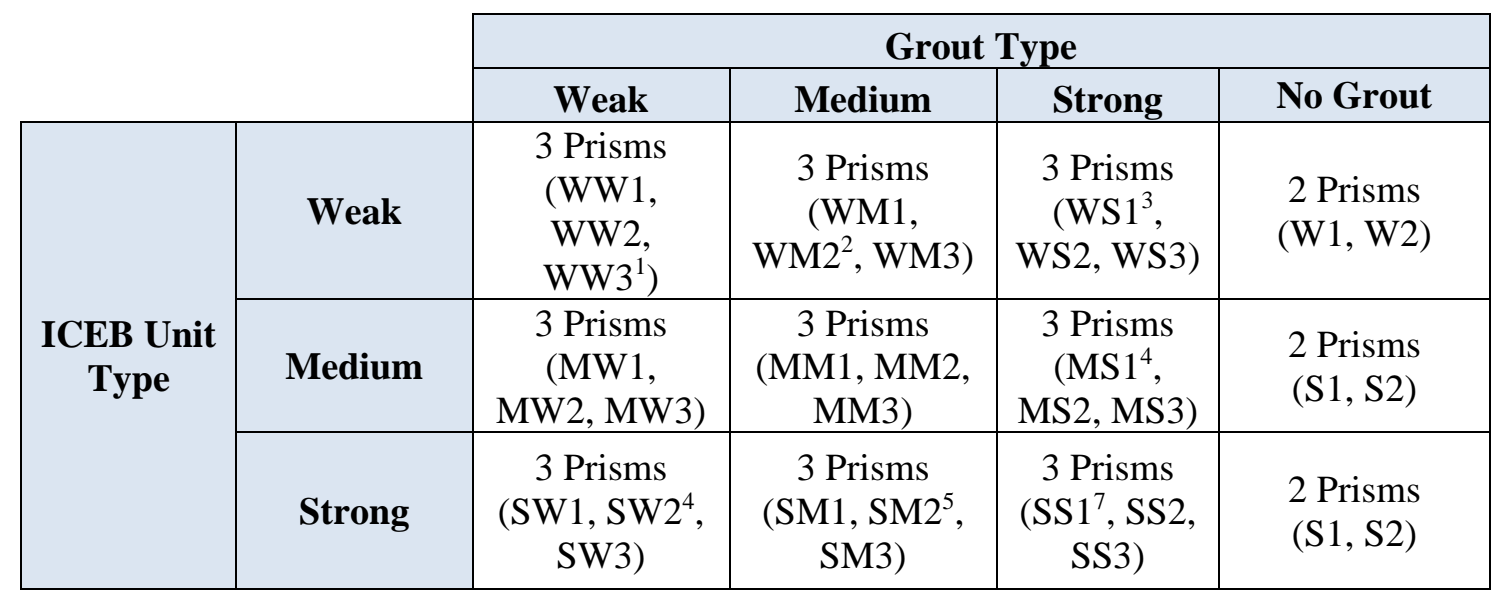

(1) Cycled at 3.2k (2) Cycled at 2.8k (3), Cycled at 2.5k (4) Cycled at 7.04k (5) Cycled at 3.2k (6) Cycled at 10.1k (7) Cycled at $10.58 \mathrm{k}$ 


\subsubsection{Prism Hydrostone Capping}

To ensure loads were transferred uniformly, all prisms were capped on a flat surface with a hydrostone capping compound. All prisms were capped with the same methodology and hydrostone capping compound as described ASTM C1552. 


\subsubsection{Average Prism Dimensions}

Measurements were taken at two opposite locations at both the top and bottom unit for all prism dimensions. Averaged dimensions were largely consistent among all fully grouted prisms (Table 21) and un-grouted prisms (Table 22).

Table 21: Fully Grouted Prism Dimensions

\begin{tabular}{|c|c|c|c|c|}
\hline $\begin{array}{l}\text { Fully Grouted } \\
\text { Prism Name }\end{array}$ & $\begin{array}{c}\text { Average } \\
\text { Prism } \\
\text { Length } \\
\left(l_{p}\right) \\
\end{array}$ & $\begin{array}{c}\text { Average } \\
\text { Prism Width } \\
\left(w_{p}\right)\end{array}$ & $\begin{array}{c}\text { Average } \\
\text { Prism Height } \\
\left(h_{p}\right)\end{array}$ & $\begin{array}{l}\text { Area } \\
\left(A_{p}\right)\end{array}$ \\
\hline WW & $\begin{array}{l}148 \mathrm{~mm} \\
(5.82 \mathrm{in})\end{array}$ & $\begin{array}{l}148 \mathrm{~mm} \\
\text { (5.81 in) }\end{array}$ & $\begin{array}{c}314 \mathrm{~mm} \\
(12.36 \mathrm{in})\end{array}$ & $\begin{array}{c}859 \mathrm{~mm}^{2} \\
\left(33.80 \mathrm{in}^{2}\right)\end{array}$ \\
\hline MW & $\begin{array}{l}148 \mathrm{~mm} \\
(5.84 \mathrm{in})\end{array}$ & $\begin{array}{l}148 \mathrm{~mm} \\
(5.84 \mathrm{in})\end{array}$ & $\begin{array}{l}316 \mathrm{~mm} \\
(12.43 \mathrm{in})\end{array}$ & $\begin{array}{l}866 \mathrm{~mm}^{2} \\
\left(34.10 \mathrm{in}^{2}\right)\end{array}$ \\
\hline SW & $\begin{array}{l}149 \mathrm{~mm} \\
(5.86 \mathrm{in})\end{array}$ & $\begin{array}{l}149 \mathrm{~mm} \\
\text { (5.86 in) }\end{array}$ & $\begin{array}{c}314 \mathrm{~mm} \\
(12.36 \mathrm{in})\end{array}$ & $\begin{array}{c}873 \mathrm{~mm}^{2} \\
\left(34.36 \mathrm{in}^{2}\right)\end{array}$ \\
\hline WM & $\begin{array}{l}148 \mathrm{~mm} \\
(5.82 \mathrm{in})\end{array}$ & $\begin{array}{l}148 \mathrm{~mm} \\
(5.81 \mathrm{in})\end{array}$ & $\begin{array}{c}320 \mathrm{~mm} \\
(12.59 \mathrm{in})\end{array}$ & $\begin{array}{c}859 \mathrm{~mm}^{2} \\
\left(33.82 \mathrm{in}^{2}\right)\end{array}$ \\
\hline $\mathbf{M M}$ & $\begin{array}{l}149 \mathrm{~mm} \\
(5.86 \mathrm{in})\end{array}$ & $\begin{array}{l}149 \mathrm{~mm} \\
(5.86 \mathrm{in})\end{array}$ & $\begin{array}{c}319 \mathrm{~mm} \\
(12.54 \mathrm{in})\end{array}$ & $\begin{array}{c}871 \mathrm{~mm}^{2} \\
\left(34.31 \mathrm{in}^{2}\right)\end{array}$ \\
\hline SM & $\begin{array}{l}149 \mathrm{~mm} \\
(5.86 \mathrm{in})\end{array}$ & $\begin{array}{l}149 \mathrm{~mm} \\
\text { (5.86 in) }\end{array}$ & $\begin{array}{c}319 \mathrm{~mm} \\
(12.54 \mathrm{in})\end{array}$ & $\begin{array}{c}871 \mathrm{~mm}^{2} \\
\left(34.29 \mathrm{in}^{2}\right)\end{array}$ \\
\hline WS & $\begin{array}{l}147 \mathrm{~mm} \\
\text { (5.81 in) }\end{array}$ & $\begin{array}{l}149 \mathrm{~mm} \\
(5.86 \mathrm{in})\end{array}$ & $\begin{array}{c}319 \mathrm{~mm} \\
(12.54 \mathrm{in})\end{array}$ & $\begin{array}{c}865 \mathrm{~mm}^{2} \\
\left(34.05 \mathrm{in}^{2}\right)\end{array}$ \\
\hline MS & $\begin{array}{l}149 \mathrm{~mm} \\
(5.85 \mathrm{in})\end{array}$ & $\begin{array}{l}149 \mathrm{~mm} \\
\text { (5.86 in) }\end{array}$ & $\begin{array}{c}320 \mathrm{~mm} \\
(12.58 \mathrm{in})\end{array}$ & $\begin{array}{c}872 \mathrm{~mm}^{2} \\
\left(34.32 \mathrm{in}^{2}\right)\end{array}$ \\
\hline SS & $\begin{array}{l}144 \mathrm{~mm} \\
\text { (5.68 in) }\end{array}$ & $\begin{array}{l}149 \mathrm{~mm} \\
(5.88 \mathrm{in})\end{array}$ & $\begin{array}{c}313 \mathrm{~mm} \\
(12.33 \mathrm{in})\end{array}$ & $\begin{array}{r}848 \mathrm{~mm}^{2} \\
\left(33.38 \mathrm{in}^{2}\right)\end{array}$ \\
\hline $\begin{array}{c}\text { Coefficient of } \\
\text { Variance }\end{array}$ & $1.0 \%$ & $0.4 \%$ & $0.8 \%$ & $1.0 \%$ \\
\hline
\end{tabular}


Table 22: Un-grouted Prism Dimensions

\begin{tabular}{|c|c|c|c|c|c|c|c|c|}
\hline $\begin{array}{c}\text { Un- } \\
\text { grouted } \\
\text { Prism } \\
\text { Name }\end{array}$ & $\begin{array}{c}\text { Average } \\
\text { Prism } \\
\text { Length } \\
\left(\boldsymbol{l}_{\boldsymbol{p}}\right)\end{array}$ & $\begin{array}{c}\text { Average } \\
\text { Prism } \\
\text { Width } \\
\left(\boldsymbol{w}_{\boldsymbol{p}}\right)\end{array}$ & $\begin{array}{c}\text { Average } \\
\text { Prism } \\
\text { Height } \\
\left(\boldsymbol{h}_{\boldsymbol{p}}\right)\end{array}$ & $\begin{array}{c}\text { Average } \\
\text { Reinforce- } \\
\text { ment Hole } \\
\text { Diameter } \\
\left(\boldsymbol{d}_{\boldsymbol{p}}\right)\end{array}$ & $\begin{array}{c}\text { Averag } \\
\mathbf{e} \\
\text { Channe } \\
\mathbf{l} \\
\text { Length } \\
\left(\boldsymbol{l}_{\boldsymbol{g}}\right)\end{array}$ & $\begin{array}{c}\text { Averag } \\
\mathbf{e} \\
\text { Channe } \\
\mathbf{I} \text { Width } \\
\left(\boldsymbol{w}_{\boldsymbol{g}}\right)\end{array}$ & $\begin{array}{c}\text { Area Net } \\
\left(\boldsymbol{A}_{\boldsymbol{p g}}\right)\end{array}$ & $\begin{array}{c}\text { Area } \\
\text { Gross } \\
\left(\boldsymbol{A}_{\boldsymbol{p} \boldsymbol{n}}\right)\end{array}$ \\
\hline $\mathbf{W}$ & $\begin{array}{c}148 \mathrm{~mm} \\
(5.85 \mathrm{in})\end{array}$ & $\begin{array}{c}149 \mathrm{~mm} \\
(5.85 \mathrm{in})\end{array}$ & $\begin{array}{c}311 \mathrm{~mm} \\
(12.25 \mathrm{in})\end{array}$ & $\begin{array}{c}44 \mathrm{~mm} \\
(1.73 \mathrm{in})\end{array}$ & $\begin{array}{c}23 \mathrm{~mm} \\
(0.90 \mathrm{in})\end{array}$ & $\begin{array}{c}24 \mathrm{~mm} \\
(0.94 \mathrm{in})\end{array}$ & $\begin{array}{c}787 \mathrm{~mm}^{2} \\
\left(31.00 \mathrm{in}^{2}\right)\end{array}$ & $\begin{array}{c}869 \mathrm{~mm}^{2} \\
\left(34.19 \mathrm{in}^{2}\right)\end{array}$ \\
\hline $\mathbf{M}$ & $\begin{array}{c}149 \mathrm{~mm} \\
(5.85 \mathrm{in})\end{array}$ & $\begin{array}{c}149 \mathrm{~mm} \\
(5.86 \mathrm{in})\end{array}$ & $\begin{array}{c}314 \mathrm{~mm} \\
(12.38 \mathrm{in})\end{array}$ & $\begin{array}{c}44 \mathrm{~mm} \\
(1.73 \mathrm{in})\end{array}$ & $\begin{array}{c}22 \mathrm{~mm} \\
(0.88 \mathrm{in})\end{array}$ & $\begin{array}{c}24 \mathrm{~mm} \\
(0.95 \mathrm{in})\end{array}$ & $\begin{array}{c}790 \mathrm{~mm}^{2} \\
\left(31.09 \mathrm{in}^{2}\right)\end{array}$ & $\begin{array}{c}871 \mathrm{~mm}^{2} \\
\left(34.28 \mathrm{in}^{2}\right)\end{array}$ \\
\hline $\mathbf{S}$ & $\begin{array}{c}149 \mathrm{~mm} \\
(5.88 \mathrm{in})\end{array}$ & $\begin{array}{c}148 \mathrm{~mm} \\
(5.85 \mathrm{in})\end{array}$ & $\begin{array}{c}308 \mathrm{~mm} \\
(12.13 \mathrm{in})\end{array}$ & $\begin{array}{c}44 \mathrm{~mm} \\
(1.73 \mathrm{in})\end{array}$ & $\begin{array}{c}23 \mathrm{~mm} \\
(0.91 \mathrm{in})\end{array}$ & $\begin{array}{c}24 \mathrm{~mm} \\
(0.94 \mathrm{in})\end{array}$ & $\begin{array}{c}791 \mathrm{~mm}^{2} \\
\left(31.13 \mathrm{in}^{2}\right)\end{array}$ & $\begin{array}{c}872 \mathrm{~mm}^{2} \\
\left(34.34 \mathrm{in}^{2}\right)\end{array}$ \\
\hline C.O.V. & $0.27 \%$ & $0.13 \%$ & $1.02 \%$ & $0 \%$ & $1.70 \%$ & $0.61 \%$ & $0.23 \%$ & $0.21 \%$ \\
\hline
\end{tabular}

\subsubsection{Prism Curing}

All prisms were cured next to grout and lap splice specimens to ensure consistent curing conditions. The top of each prism was covered with a layer of plastic wrap to minimize water loss. All prisms were allowed to cure for a minimum of 28 days and were tested within +/- 1 day of grout and lap splice specimens. All prisms were tested in the Civil Engineering lab at Cal Poly, San Luis Obispo. All prisms compressive tests were run at a rate of $0.06 \mathrm{in} / \mathrm{min}$. 


\subsubsection{Prism Instrumentation and Testing}

All prisms specimens were equipped with two LVDTs and two 8 inch extensometers on opposite ends. The LVDTs measured the displacement between the top and bottom plate. The extensometers measured displacement within an 8-inch range from the middle of the top ICEB unit to the middle of the bottom ICEB unit (Figure 18).

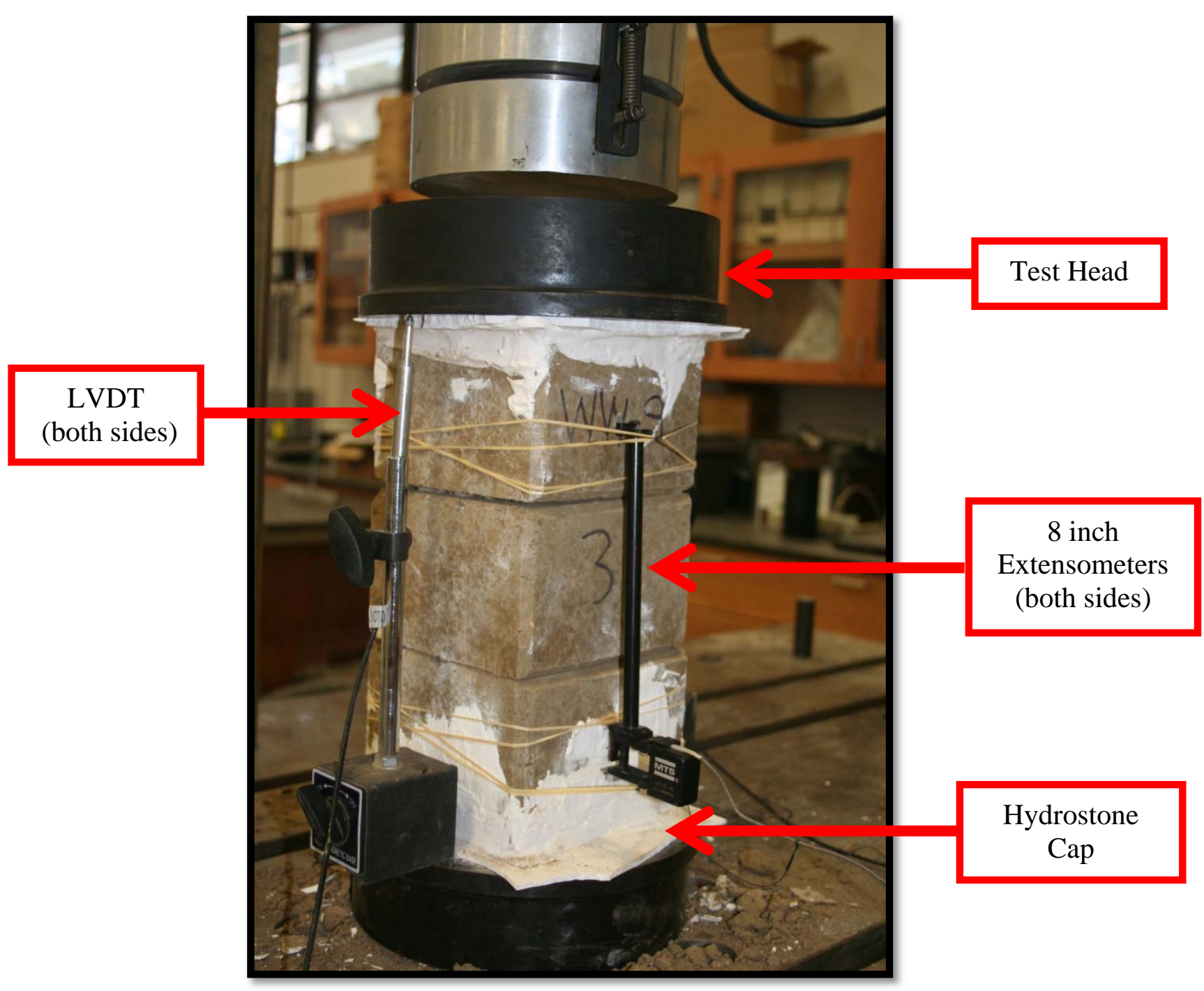

Figure 18: Prism Test Set Up 


\subsubsection{Typical Prism Cone Fracture Failure}

Conical fracture failure was typically observed during compressive failure of prism specimens. Per ASTM 39-03, the conical shape is formed by the unconfined lateral expansion at the center of specimen. Friction at the top and bottom of the testing plates confines the specimen from expanding thus resulting in the conical shape shown below in Figure 19.

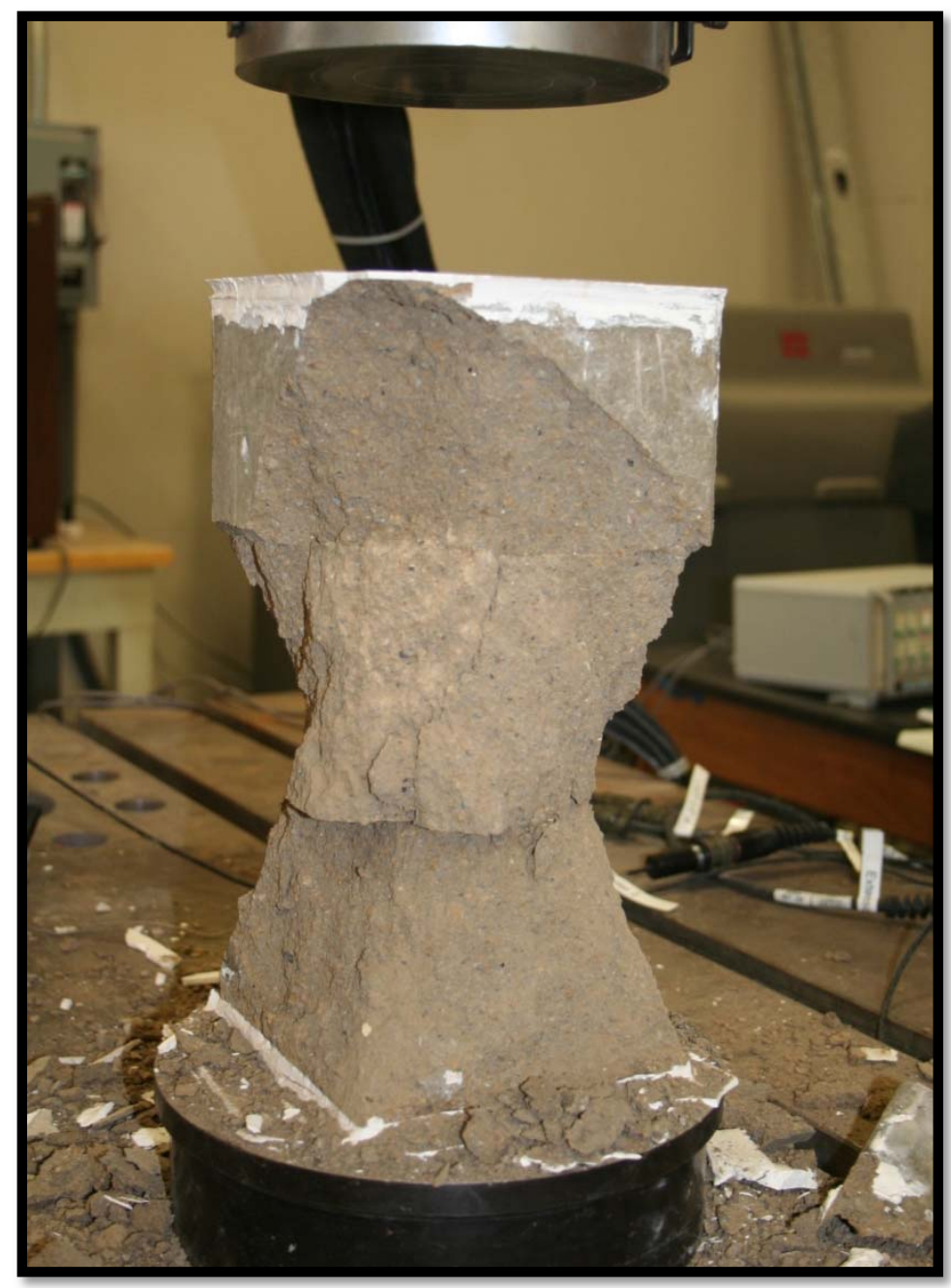

Figure 19: Typical Failure Shape of Prism 


\subsubsection{Summary of Prism Strengths $\left(\boldsymbol{f}^{\prime}{ }_{m}\right)$}

The specified compressive strength of ICEB masonry $\left(f_{m}^{\prime}\right)$ was established through the compressive testing of 27 fully grouted ICEB prisms. Table 23 summarizes the average prism compressive strength $\left(f_{m}^{\prime}\right)$ in bold and un-grouted compressive strength $\left(f^{\prime}{ }_{u m}\right)$ in italics. The ICEB unit and grout strengths are listed under each strength type, respectively.

Table 23: Summary of Fully Grouted Prism Compressive Strengths $\left(\boldsymbol{f}^{\prime}{ }_{m}\right)$ vs. Grout Compressive Strength $\left(\boldsymbol{f}^{\prime}{ }_{g}\right)$ and ICEB Unit Compressive Strength $\left(\boldsymbol{f}^{\prime}{ }_{b}\right)$

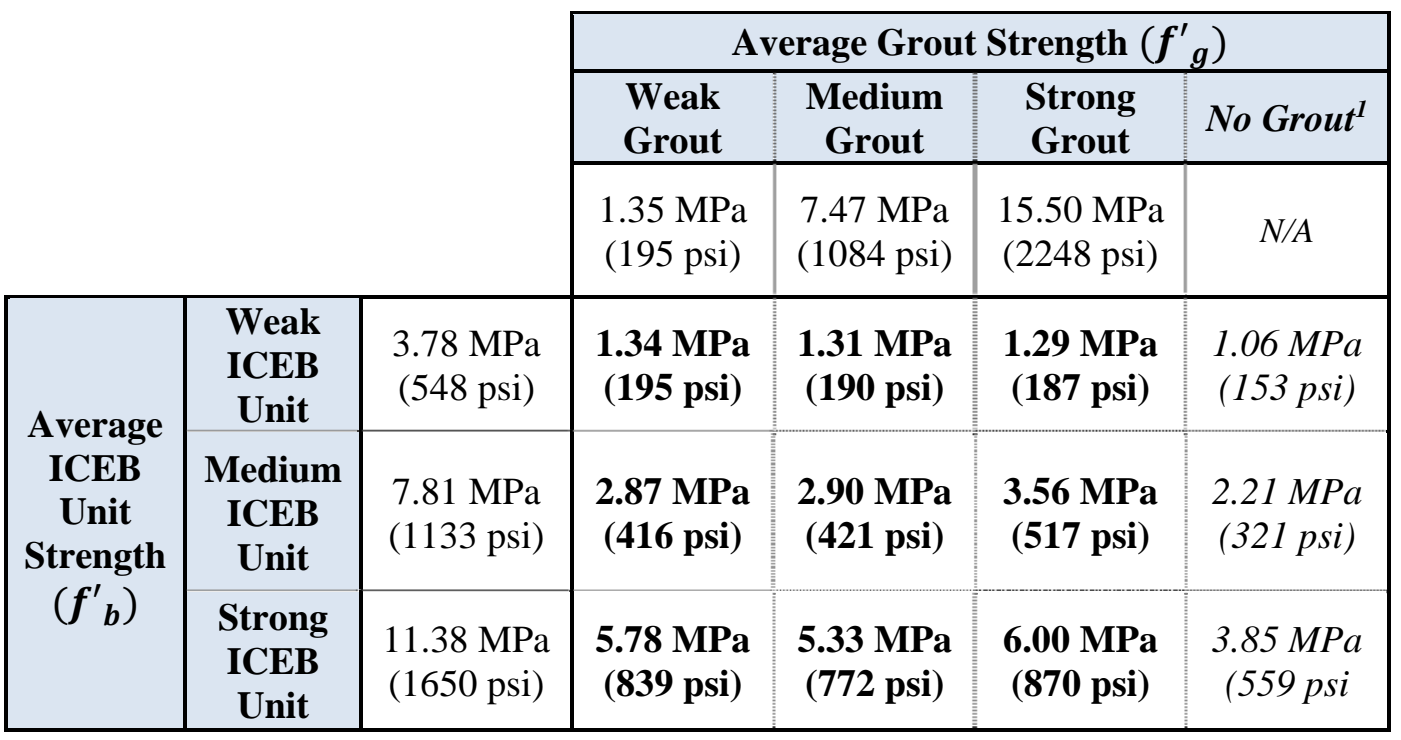

(1) Compressive strength of the un-grouted prism was calculated by net area $\left(A_{n}\right)$ of the prism as defined in Section 3.4.8.

ICEB prism compressive strength $\left(f^{\prime}{ }_{m}\right)$ was directly proportional to the compressive strength of the ICEB unit $\left(f^{\prime}{ }_{b}\right)$ used in construction of the prism. Stronger ICEB units $\left(f_{b}^{\prime}\right)$ produced stronger prisms $\left(f_{m}^{\prime}\right)$ (Figure 20) while stronger grout $\left(f_{g}^{\prime}\right)$ had little effect on the strength of the prism $\left(f^{\prime}{ }_{m}\right)$ (Figure 21), as long as the prism was grouted. Prisms that were not grouted were significantly weaker than prisms that had been grouted. 


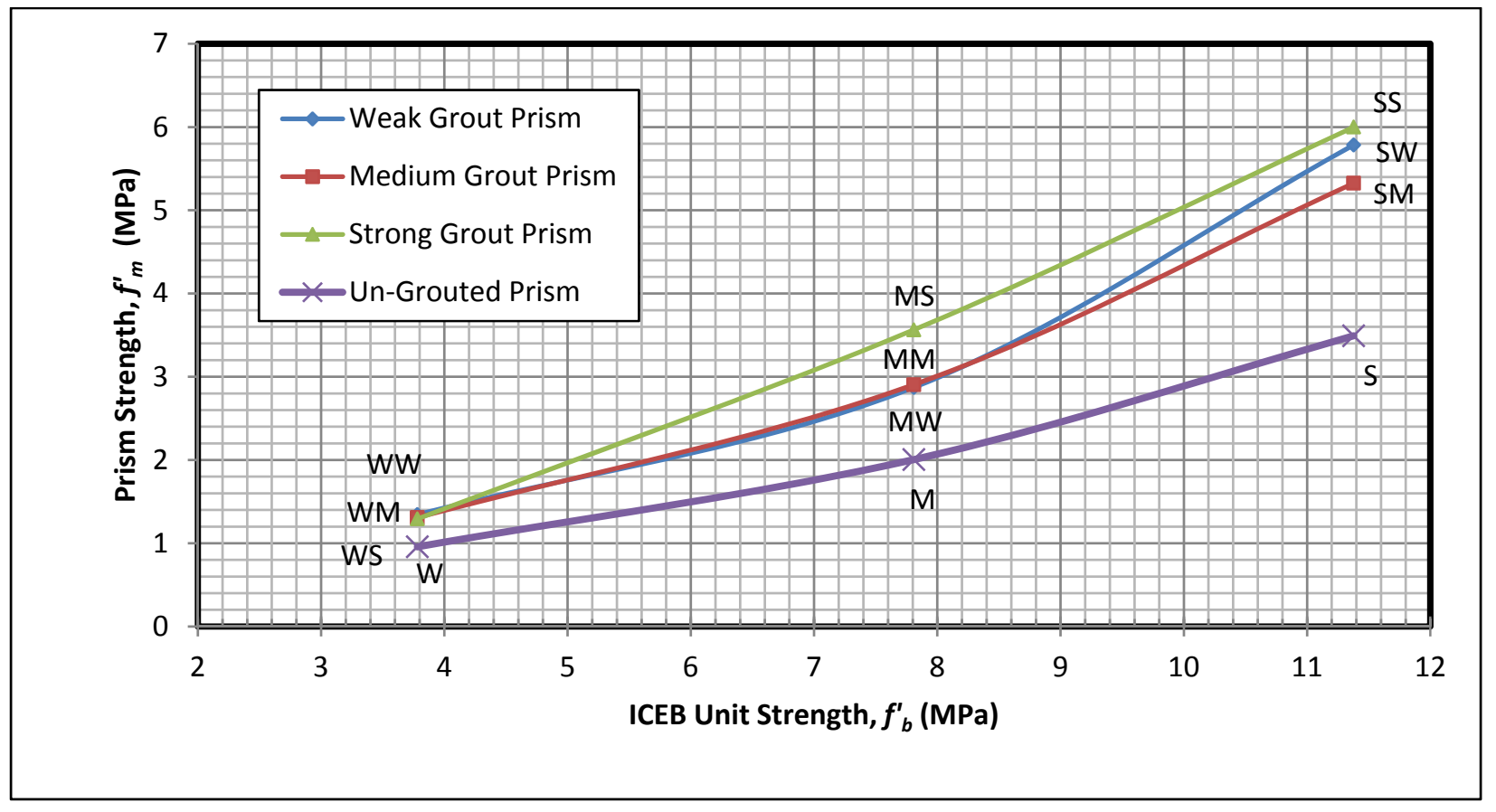

Figure 20: ICEB Unit Compressive Strength $\left(\boldsymbol{f}_{b}^{\prime}\right)$ vs. Prism Compressive Strength $\left(\boldsymbol{f}_{m}^{\prime}\right)$

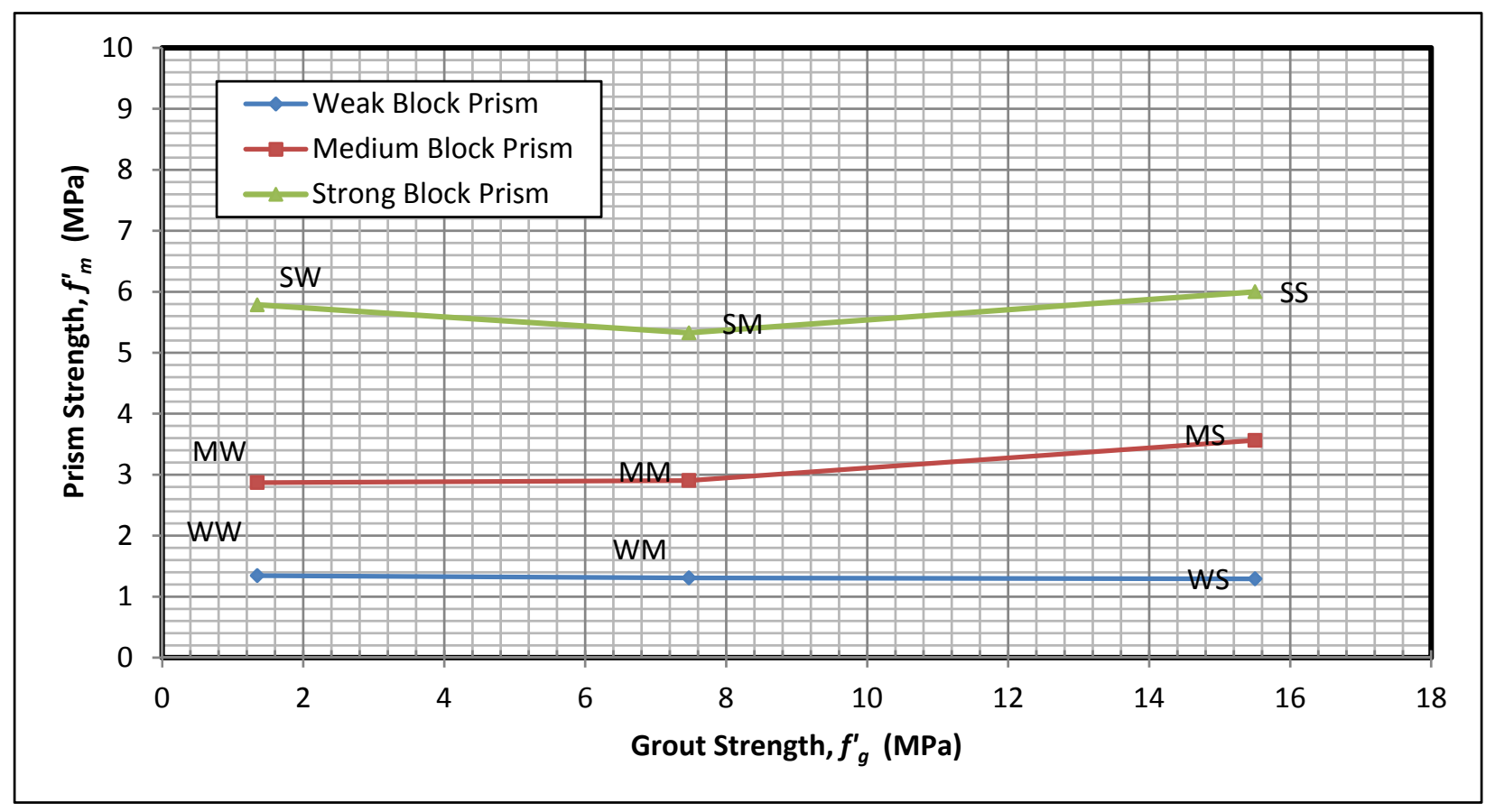

Figure 21: Grout Compressive Strength $\left(\boldsymbol{f}_{\boldsymbol{g}}^{\prime}\right)$ vs. Prism Compressive Strength $\left(\boldsymbol{f}^{\prime}{ }_{m}\right)$ 
Un-grouted prisms built from strong, medium, and weak ICEB unit strengths were compressive tested for comparison purposes. Fully grouted prisms were significantly stronger than the compressive strength of un-grouted prisms (Table 24). This indicates that fully grouted a prism will significantly increase the overall prism compressive strength $\left(f^{\prime}{ }_{m}\right)$ regardless of the strength of the grout $\left(f^{\prime}{ }_{g}\right)$.

Table 24: Fully Grouted Prism Strength $\left(\boldsymbol{f}^{\prime}{ }_{m}\right)$ vs. Un-Grouted Prism Strength $\left(\boldsymbol{f}^{\prime}{ }_{u m}\right)$

\begin{tabular}{|c|c|c|c|c|c|}
\hline \multirow[b]{2}{*}{$\begin{array}{l}\text { ICEB Unit Type } \\
\text { Used to } \\
\text { Construct Prism }\end{array}$} & \multirow{2}{*}{$\begin{array}{c}\text { Average } \\
\text { Fully } \\
\text { Grouted } \\
\text { Prism } \\
\text { Compressive } \\
\text { Strength } \\
\left(\boldsymbol{f}^{\prime}{ }_{m}\right)\end{array}$} & \multicolumn{2}{|c|}{$\begin{array}{c}\text { Average Un-Grouted } \\
\text { Prism Strength }\left(\boldsymbol{f}^{\prime}{ }_{u m}\right)\end{array}$} & \multicolumn{2}{|c|}{ \% Strength Difference } \\
\hline & & $\begin{array}{l}\text { Area Net } \\
\qquad\left(A_{n}\right)\end{array}$ & $\begin{array}{l}\text { Area Gross } \\
\qquad\left(\boldsymbol{A}_{\boldsymbol{g}}\right)\end{array}$ & $\begin{array}{l}\text { Area Net } \\
\qquad\left(A_{n}\right)\end{array}$ & $\begin{array}{c}\text { Area } \\
\text { Gross } \\
\left(\boldsymbol{A}_{\boldsymbol{g}}\right)\end{array}$ \\
\hline Weak & $\begin{array}{l}1.32 \mathrm{MPa} \\
\text { (191 psi) }\end{array}$ & $\begin{array}{l}1.06 \mathrm{MPa} \\
\text { (153 psi) }\end{array}$ & $\begin{array}{c}0.96 \mathrm{MPa} \\
(139 \mathrm{psi})\end{array}$ & $22 \%$ & $32 \%$ \\
\hline Medium & $\begin{array}{r}3.11 \mathrm{MPa} \\
\text { (452 psi) }\end{array}$ & $\begin{array}{c}2.21 \mathrm{MPa} \\
\text { (321 psi) }\end{array}$ & $\begin{array}{r}2.01 \mathrm{MPa} \\
\text { (291 psi) }\end{array}$ & $34 \%$ & $43 \%$ \\
\hline Strong & $\begin{array}{c}5.70 \mathrm{MPa} \\
(827 \mathrm{psi})\end{array}$ & $\begin{array}{c}3.85 \mathrm{MPa} \\
(559 \mathrm{psi})\end{array}$ & $\begin{array}{c}3.49 \mathrm{MPa} \\
\text { (506 psi) }\end{array}$ & $39 \%$ & $48 \%$ \\
\hline
\end{tabular}




\subsubsection{Bland (2011) and Herskedal (2012) vs Tested ICEB Prism Compressive Strength $\left(\boldsymbol{f}^{\prime}{ }_{m}\right)$}

The average compressive strength $\left(f^{\prime}{ }_{m}\right)$ of medium strength ICEB prisms produced in this research was nearly identical to the compressive strength $\left(f^{\prime}{ }_{m}\right)$ of ICEB prisms produced in Bland (2011) and Herskedal (2012) (Table 25). However, both Bland (2011) and Herskedal (2012) constructed prisms from grout that was 20\% stronger than the grout strength $\left(f^{\prime}{ }_{g}\right)$ used to produce prisms in this research. The ICEB units used in the construction of prisms in Bland (2011), Herskedal (2012), and in this research, were constructed from the same mix ratio of sand, soil, cement, and water (Section 3.4.1). The tested ICEB unit strength $\left(f^{\prime}{ }_{b}\right)$ found in this research was identical with the ICEB unit strengths $\left(f^{\prime}{ }_{b}\right)$ tested in Bland (2011) and Herskedal (2012). These findings further suggest that the strength of an ICEB prism $\left(f^{\prime}{ }_{m}\right)$ is controlled by the strength of the ICEB unit $\left(f^{\prime}{ }_{b}\right)$ as there is no discernable correlation between the strength of the prism $\left(f_{m}^{\prime}\right)$ and the strength of the grout $\left(f_{g}^{\prime}\right)$. This is consistent with findings in Section 3.7.8, where the ICEB prism compressive strength $\left(f^{\prime}{ }_{m}\right)$ was found to be proportional to the ICEB unit compressive strength $\left(f^{\prime}{ }_{b}\right)$ and not proportional to the grout compressive strength $\left(f_{g}^{\prime}\right)$. 
Table 25: Bland (2011), Herskedal (2012) vs. Tested Material Strength

\begin{tabular}{|c|c|c|c|c|c|}
\hline & \multirow{2}{*}{$\begin{array}{l}\text { Tested Material } \\
\text { Strength }^{1}\end{array}$} & \multicolumn{2}{|c|}{ Bland (2011) } & \multicolumn{2}{|c|}{ Herskedal (2012) } \\
\hline & & $\begin{array}{l}\text { Material } \\
\text { Strength }\end{array}$ & $\begin{array}{c}\text { Percent } \\
\text { Difference } \\
\text { from } \\
\text { Tested } \\
\end{array}$ & $\begin{array}{l}\text { Material } \\
\text { Strength }\end{array}$ & $\begin{array}{c}\text { Percent } \\
\text { Difference } \\
\text { from } \\
\text { Tested } \\
\end{array}$ \\
\hline $\begin{array}{l}\text { Average Grout } \\
\text { Compressive } \\
\text { Strength }\left(\boldsymbol{f}^{\prime} \boldsymbol{g}\right)\end{array}$ & $\begin{array}{c}7.47 \mathrm{MPa} \\
\text { (1084 psi) }\end{array}$ & $\begin{array}{c}9.17 \mathrm{MPa} \\
\text { (1330 psi) }\end{array}$ & $20 \%$ & $\begin{array}{l}9.19 \mathrm{MPa} \\
\text { (1333 psi) }\end{array}$ & $20.6 \%$ \\
\hline $\begin{array}{l}\text { Average ICEB } \\
\text { Unit Compressive } \\
\text { Strength }\left(\boldsymbol{f}^{\prime}{ }_{b}\right)\end{array}$ & $\begin{array}{l}7.81 \mathrm{MPa} \\
\text { (1133 psi) }\end{array}$ & $\begin{array}{l}7.57 \mathrm{MPa} \\
(1098 \mathrm{psi})\end{array}$ & $-3.0 \%$ & $\begin{array}{l}7.76 \mathrm{MPa} \\
(1126 \mathrm{psi})\end{array}$ & $-0.6 \%$ \\
\hline $\begin{array}{c}\text { Average Prism } \\
\text { Compressive } \\
\text { Strength }\left(\boldsymbol{f}^{\prime}{ }_{\boldsymbol{m}}\right)\end{array}$ & $\begin{array}{l}2.90 \mathrm{MPa} \\
\text { (421 psi) }\end{array}$ & $\begin{array}{l}3.00 \mathrm{MPa} \\
\text { (435 psi) }\end{array}$ & $3.4 \%$ & $\begin{array}{l}2.81 \mathrm{MPa} \\
(408 \mathrm{psi})\end{array}$ & $-3.2 \%$ \\
\hline
\end{tabular}

(1) Material strength of specimens produced in Bland (2011) and Herskedal (2012) compared against tested medium strength grout, medium strength ICEB units, and medium strength prism specimens 


\subsubsection{Prism Compressive Strength $\left(\boldsymbol{f}^{\prime}{ }_{\boldsymbol{m}}\right)$ vs. ICEB Batch Compressive Strength $\left(\boldsymbol{f}^{\prime}{ }_{b s}\right)$}

As discussed earlier, in Section 3.4.10, one ICEB unit from every 16 ICEB unit batch press was compressive tested to ensure uniformity and quality of all batches. The compressive strength of single ICEB unit from each 16 ICEB unit batch is denoted by $\left(f^{\prime}{ }_{b s}\right)$. Each prism specimen was constructed from three stacked ICEB units from the same 16 ICEB unit batch. The prism compressive strength $\left(f_{m}^{\prime}\right)$ was compared against the compressive strength of the ICEB unit $\left(f^{\prime}{ }_{b s}\right)$ to determine if a correlation existed between ICEB unit batch strength $\left(f^{\prime}{ }_{b s}\right)$ and the strength of the prism $\left(f^{\prime}{ }_{m}\right)$. The strength of the prism specimen did not demonstrate a strong correlation to the strength of the single ICEB unit from which it was constructed (see Figure 22 on the next page or Appendix D: Table 43). This may be due to the inherent strength variability among ICEB units, even among units that are pressed in the same batch. This research used the average compressive strength of the ICEB unit $\left(f^{\prime}{ }_{b}\right)$ in subsequent analysis and not the ICEB unit compressive batch strength $\left(f^{\prime}{ }_{b s}\right)$. 


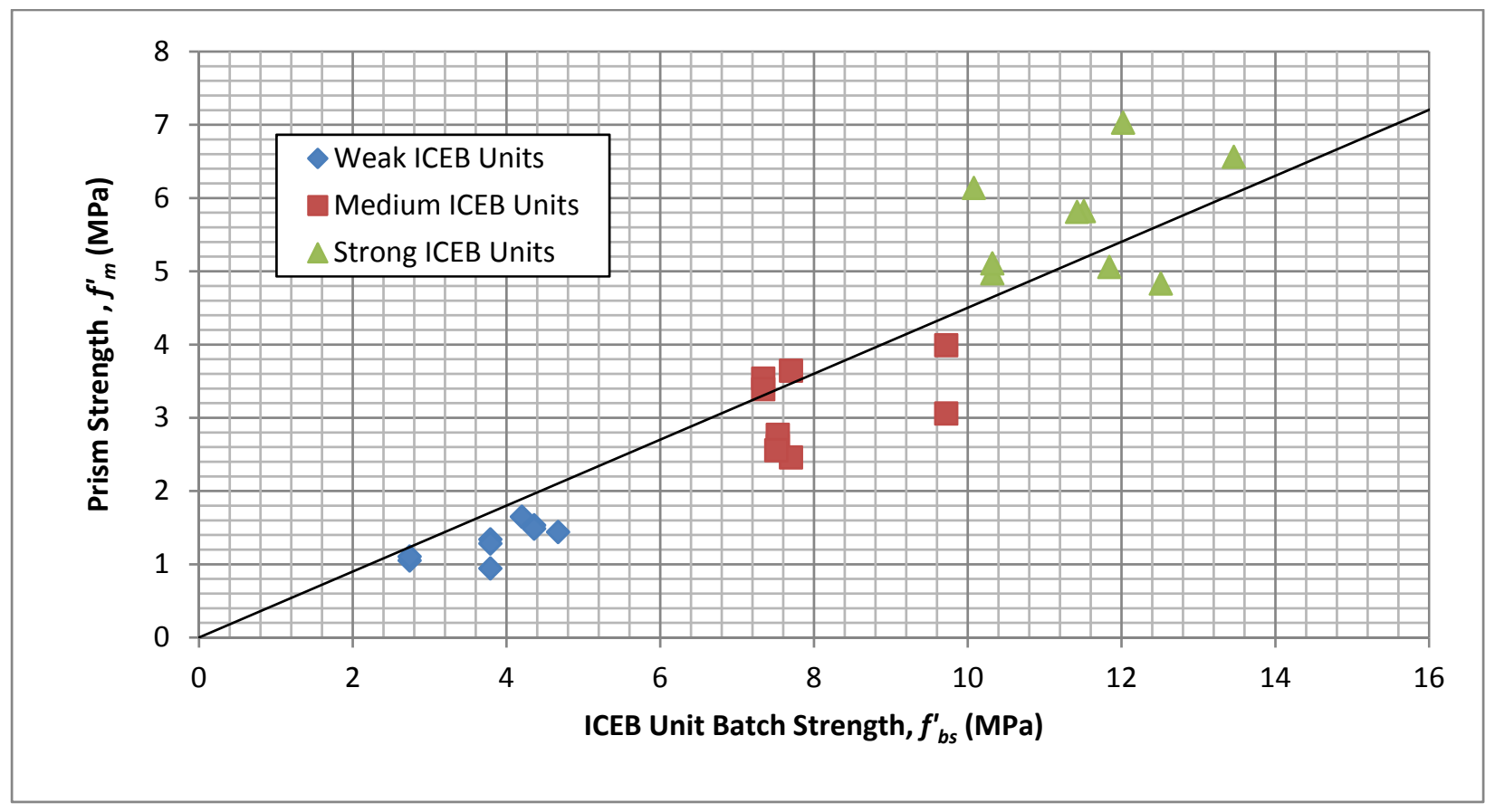

Figure 22: ICEB Prism Strength $\left(\boldsymbol{f}^{\prime}{ }_{m}\right)$ vs. ICEB Batch Compressive $\operatorname{Strength}\left(\boldsymbol{f}^{\prime}{ }_{b}\right)$ 


\subsubsection{ICEB Prism Prediction Equation Analysis}

A regression analysis was used to develop three equations that represented the relationship among the average ICEB unit compressive strength $\left(f^{\prime}{ }_{b}\right)$ and the average prism compressive strength $\left(f^{\prime} m\right)$ (Table 26). The average grout strength $\left(f^{\prime} g\right)$ was not used in the predictive models as there was no correlation between the strength of the grout and the prism strength (see Section 3.7.8), if the prism was fully grouted.

Table 26: Prism Prediction Equations

\begin{tabular}{|c|c|c|c|}
\hline $\begin{array}{c}\text { Equation } \\
\text { Number }\end{array}$ & Type & Equation & $\mathbf{R}^{2}$ Factor \\
\hline 3.1 & Linear & $f^{\prime}{ }_{m p 1}=0.46 \times f^{\prime}{ }_{b}$ & 0.860 \\
\hline 3.2 & Power & $f^{\prime}{ }_{m p 2}=0.22 \times\left(f^{\prime}{ }_{b}\right)^{1.32}$ & 0.929 \\
\hline 3.3 & Polynomial & $f^{\prime}{ }_{m p 3}=0.036 \times\left(f^{\prime}{ }_{b}\right)^{2}+2.3 \times f^{\prime}{ }_{b}$ & 0.917 \\
\hline
\end{tabular}

Where:

${f^{\prime}}_{m p}=$ Predicted Strength of Grouted Prisms $(M P a)$

and

${f^{\prime}}^{\prime}=$ Average ICEB Unit Strength $(M P a)$

The polynomial model (Equation 3.1) grossly over predicted strengths for prisms constructed from stronger ICEB units while the linear model (Equation 3.3) was most accurate for prisms constructed from medium strength ICEB units. The power model 
(Equation 3.2) best fit the data with correlation coefficient of 0.929. Equation 3.2 was chosen as the best fit equation for the tested fully grouted prisms.

As discussed previous in Section 3.7.8, the measured compressive strength of un-grouted prisms $\left(f^{\prime}{ }_{u m}\right)$ was considerably weaker than the measured compressive strength of fully grouted prisms $\left(f_{m}^{\prime}\right)$. Equation 3.2 over-predicted the compressive strength of ungrouted prisms so a separate regression analysis was used to develop an equation that represented the relationship among the ICEB unit compressive strength $\left(f^{\prime}{ }_{b}\right)$ and the ungrouted prism compressive strength $\left(f^{\prime}{ }_{\text {um }}\right)$ (Table 27).

Table 27: Un-grouted Prism Prediction Equation

\begin{tabular}{|c|c|c|c|}
\hline $\begin{array}{c}\text { Equation } \\
\text { Number }\end{array}$ & Type & Equation & $\mathbf{R}^{2}$ Factor \\
\hline 3.4 & Power & $f^{\prime}{ }_{\text {mup }}=0.22 \times\left(f^{\prime}{ }_{b}\right)^{1.16}$ & 0.967 \\
\hline
\end{tabular}

Where:

${f^{\prime}}^{\prime}{ }_{\text {mup }}=$ Predicted Strength of Un-grouted Prisms $(M P a)$

and

${f^{\prime}}^{\prime}=$ Average ICEB Unit Strength $(M P a)$ 


\subsubsection{Prism Prediction Equation Summary}

For both un-grouted and fully grouted prisms, the compressive strength of the ICEB prism can be summarized by equation 3.5:

$$
\left(f^{\prime}{ }_{m p}\right)=0.22 \times\left(f^{\prime}{ }_{b}\right)^{A}
$$

Where:

$\mathrm{A}=1.32$ for fully grouted prisms, 1.16 for un-grouted prisms

$f^{\prime}{ }_{m p}=$ Predicted Prism Strength $(\mathrm{MPa})$

and ${f^{\prime}}^{\prime}=$ Average ICEB Unit Strength $(M P a)$

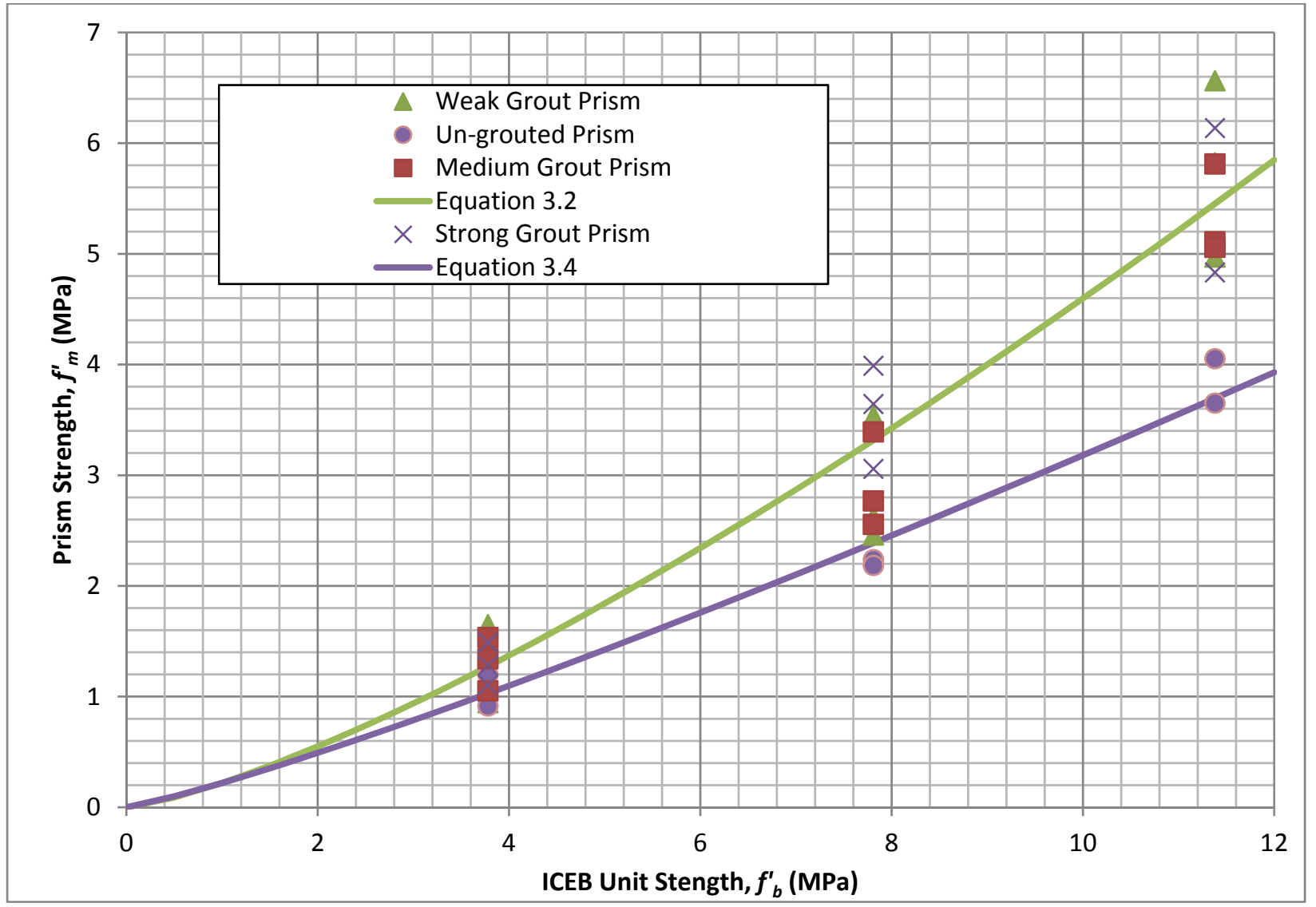

Figure 23: Relationship between ICEB Unit Strength, $\left(f^{\prime} b\right)$ and ICEB Prism Strengths, $\left(f^{\prime} m\right) \&\left(f^{\prime} m u\right)$ 


\subsection{Reinforcing Rebar}

As discussed in Section 3.5, the $150 \mathrm{~mm}$ (6 inch) diameter of the ICEB unit reinforcement hole restricted the use of rebar to sizes M10 (\#3) and M13 (\#4) in all lap splice specimens. Six random samples of each sized rebar were tested for yield strength $\left(f_{y}\right)$ and ultimate strength $\left(f_{u}\right)$ in accordance to ASTM A370-10. Samples were tested with a Satec universal test machine (Figure 24). Results of these tests are shown in Table 28.

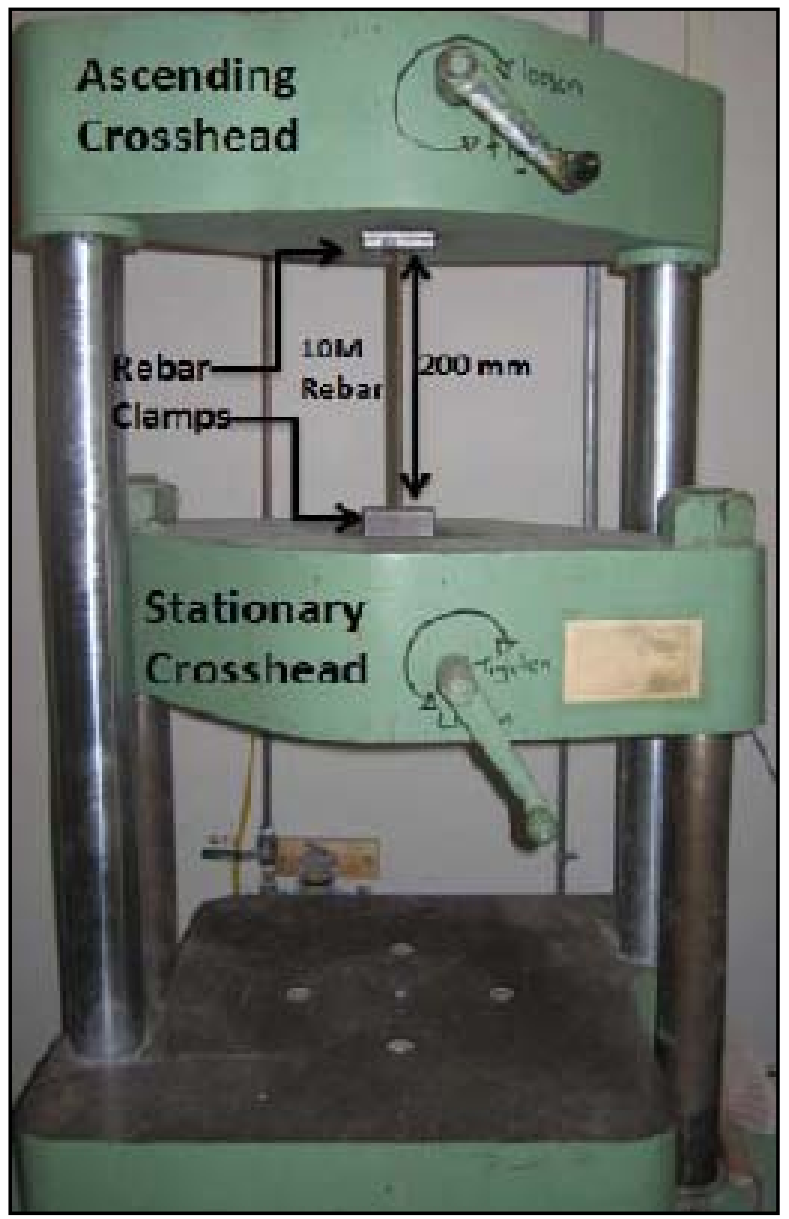

Figure 24: Satec Universal Test Machine from Sterling (2011) 
Table 28: Tensile Test of Rebar

\begin{tabular}{|c|c|c|c|}
\hline $\begin{array}{c}\text { Rebar } \\
\text { Specification }\end{array}$ & $\begin{array}{l}\text { Sample } \\
\text { Name }\end{array}$ & $\begin{array}{l}\text { Yield Tensile } \\
\text { Strength }\left(\boldsymbol{f}_{\boldsymbol{y}}\right)\end{array}$ & $\begin{array}{c}\text { Ultimate } \\
\text { Tensile } \\
\text { Strength } \\
\left(\boldsymbol{f}_{u}\right)\end{array}$ \\
\hline \multirow{6}{*}{$\begin{array}{l}\text { Size M10 } \\
\text { (\#3) Bars, } \\
\text { Grade } 40\end{array}$} & \#3-A & $\begin{array}{l}257 \mathrm{MPa} \\
(37.3 \mathrm{ksi})\end{array}$ & $\begin{array}{l}381 \mathrm{MPa} \\
\text { (55.2 ksi) }\end{array}$ \\
\hline & \#3-B & $\begin{array}{l}232 \mathrm{MPa} \\
(33.7 \mathrm{ksi})\end{array}$ & $\begin{array}{c}351 \mathrm{MPa} \\
(50.9 \mathrm{ksi})\end{array}$ \\
\hline & \#3-C & $\begin{array}{l}231 \mathrm{MPa} \\
(33.5 \mathrm{ksi})\end{array}$ & $\begin{array}{l}349 \mathrm{MPa} \\
(50.6 \mathrm{ksi})\end{array}$ \\
\hline & \#3-D & $\begin{array}{l}232 \mathrm{MPa} \\
(33.7 \mathrm{ksi})\end{array}$ & $\begin{array}{l}352 \mathrm{MPa} \\
(51.0 \mathrm{ksi})\end{array}$ \\
\hline & \#3-E & $\begin{array}{l}236 \mathrm{MPa} \\
(34.2 \mathrm{ksi})\end{array}$ & $\begin{array}{l}351 \mathrm{MPa} \\
\text { (50.9 ksi) }\end{array}$ \\
\hline & $\begin{array}{c}\text { Average } \\
\text { Tensile } \\
\text { Strength } \\
\end{array}$ & $\begin{array}{l}238 \mathrm{MPa} \\
(34.5 \mathrm{ksi})\end{array}$ & $\begin{array}{l}357 \mathrm{MPa} \\
\text { (51.7 ksi) }\end{array}$ \\
\hline \multirow{6}{*}{$\begin{array}{c}\text { Size M13 } \\
\text { (\#4) Bars, } \\
\text { Grade } 60\end{array}$} & \#4-A & $\begin{array}{l}350 \mathrm{MPa} \\
(50.7 \mathrm{ksi})\end{array}$ & $\begin{array}{l}501 \mathrm{MPa} \\
(72.7 \mathrm{ksi})\end{array}$ \\
\hline & \#4-B & $\begin{array}{l}348 \mathrm{MPa} \\
(50.5 \mathrm{ksi})\end{array}$ & $\begin{array}{l}495 \mathrm{MPa} \\
\text { (71.8 ksi) }\end{array}$ \\
\hline & \#4-C & $\begin{array}{l}357 \mathrm{MPa} \\
(51.7 \mathrm{ksi})\end{array}$ & $\begin{array}{l}510 \mathrm{MPa} \\
(73.9 \mathrm{ksi})\end{array}$ \\
\hline & \#4-D & $\begin{array}{l}357 \mathrm{MPa} \\
(51.8 \mathrm{ksi})\end{array}$ & $\begin{array}{l}507 \mathrm{MPa} \\
\text { (73.5 ksi) }\end{array}$ \\
\hline & \#4-E & $\begin{array}{l}349 \mathrm{MPa} \\
\text { (50.6 ksi) }\end{array}$ & $\begin{array}{l}493 \mathrm{MPa} \\
\text { (71.5 ksi) }\end{array}$ \\
\hline & $\begin{array}{c}\text { Average } \\
\text { Tensile } \\
\text { Strength }\end{array}$ & $\begin{array}{l}352 \mathrm{MPa} \\
\text { (51.1 ksi) }\end{array}$ & $\begin{array}{l}501 \mathrm{MPa} \\
\text { (72.7 ksi) }\end{array}$ \\
\hline
\end{tabular}




\subsubsection{Maximum Area of Reinforcement Rebar per MSJC}

Per MSJC Section 3.3.3.1, for masonry sections containing lap splices, the diameter size of reinforcing rebar is limited in size by 8 percent of the of the cell area. Due to the small area of the ICEB unit reinforcement hole $\left(15.2 \mathrm{~cm}^{2}, 2.35 \mathrm{in}^{2}\right)$ both rebar sizes M10 (\#3) and M13 (\#4) bars accounted for a large cell area with an area of reinforcement equal to $9 \%$ and $17 \%$, respectively (Table 29 ). It is impractical to use any larger bar for lap splice purposes for ICEB units constructed from the current model of the BP6 press.

Table 29: Rebar Area vs. Grout Cell Area

\begin{tabular}{|c|c|c|c|}
\hline $\begin{array}{c}\text { Rebar } \\
\text { Size }\end{array}$ & $\begin{array}{c}\text { Rebar } \\
\text { Diameter }\end{array}$ & $\begin{array}{c}\text { Rebar } \\
\text { Area (2 } \\
\text { bars) }\end{array}$ & $\begin{array}{c}\text { Percent of Cell } \\
\text { Area of Rebar }\end{array}$ \\
\hline $\begin{array}{c}\text { M10 } \\
\text { (\#3) }\end{array}$ & $\begin{array}{c}9.525 \mathrm{~mm} \\
(0.375 \mathrm{in})\end{array}$ & $\begin{array}{c}143 \mathrm{~mm}^{2} \\
\left(0.22 \mathrm{in}^{2}\right)\end{array}$ & $9 \%$ \\
\hline $\begin{array}{c}\text { M13 } \\
(\# 4)\end{array}$ & $\begin{array}{c}12.7 \mathrm{~mm} \\
(0.5 \mathrm{in})\end{array}$ & $\begin{array}{c}253 \mathrm{~mm}^{2} \\
\left(0.39 \mathrm{in}^{2}\right)\end{array}$ & $17 \%$ \\
\hline
\end{tabular}




\section{ICEB LAP SPLICE CONSTRUCTION AND TEST SET UP}

This chapter presents the construction method, test procedure, and data for the ICEB lap splice specimens that were constructed and tensile tested in this research.

\subsection{Preliminary Lap Splice Thesis Research}

During the development of this thesis plan, several preliminary ICEB lap splice specimens were produced. The results of these preliminary tests revealed that the orientation of the lap splice with respect to the side grouting channel did not affect the overall strength of the lap splice. Even so, all lap splices in this thesis were oriented in the same direction (Figure 25). Preliminary tests also concluded that tying the rebar did not affect the overall strength of the lap splice but did produce residual strength after the lap splice had failed. Cyclical residual stresses were observed to occur as the rebar would build up enough tensile stress that the rebar ties would slip past a rib of the rebar. The next rebar rib would catch the tie and the process would repeat. To avoid any possible additional strength or residual tie interference, all lap splice specimens in this thesis had all ties removed prior to testing. 


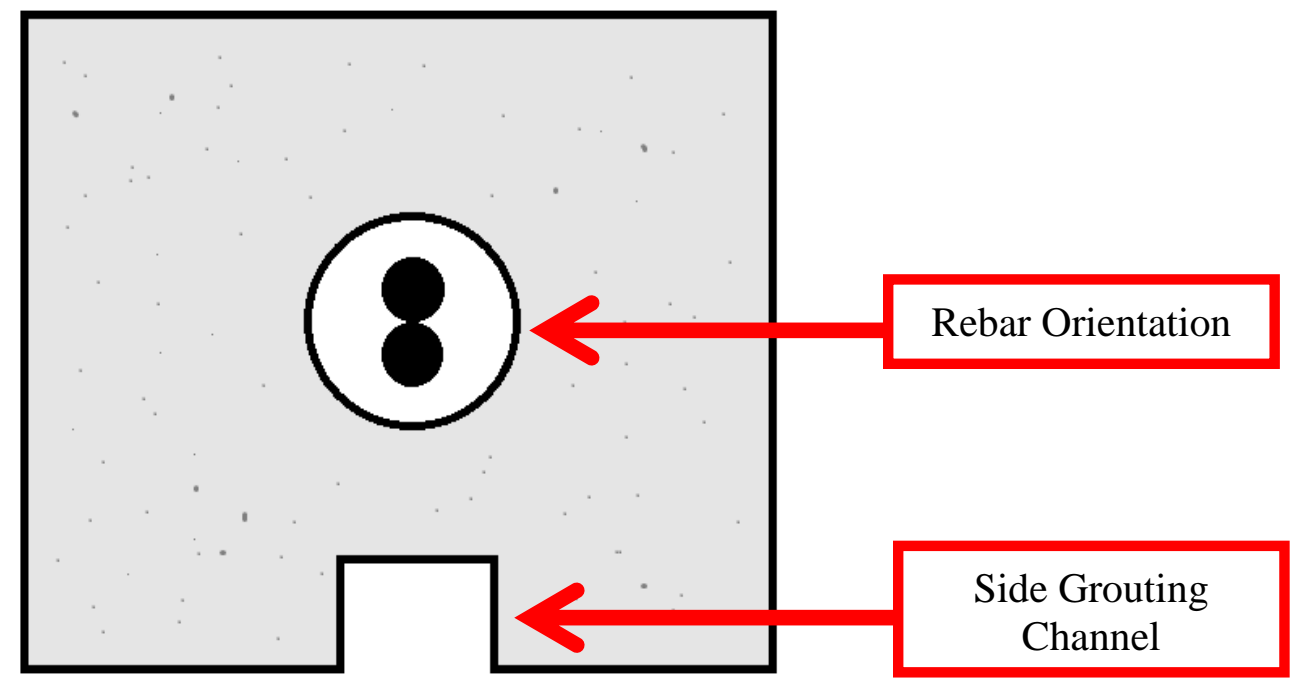

Figure 25: Lap Splice Rebar Orientation with Respect to Side Grouting Channel

\subsection{ICEB Lap Splice Testing Matrix and Specimen Name Designation}

Table 30 details the 43 ICEB Lap Splice specimens tested in this research. Specimens are named in order of bar type (\#3 or \#4), grout type (weak, medium, or strong), ICEB unit type (weak, medium, strong), and nominal lap splice length (mm). 
Table 30: Lap Splice Testing Matrix

\begin{tabular}{|c|c|c|c|c|c|}
\hline & \multirow{2}{*}{$\begin{array}{c}\text { ICEB } \\
\text { Unit } \\
\text { Strength } \\
\left(\boldsymbol{f}^{\prime}{ }_{\boldsymbol{b}}\right)\end{array}$} & \multirow{2}{*}{$\begin{array}{c}\text { Nominal Lap } \\
\text { Splice } \\
\text { Length }\left(l_{p}\right)\end{array}$} & \multicolumn{3}{|c|}{ Grout Strength $\left(\boldsymbol{f}^{\prime} \boldsymbol{g}\right)$} \\
\hline & & & weak & medium & strong \\
\hline \multirow{15}{*}{ 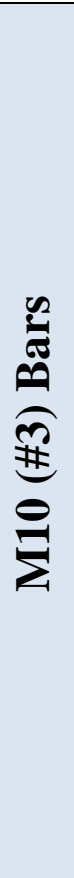 } & \multirow{5}{*}{ 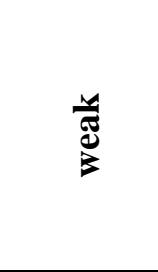 } & 500 mm (19.69 in) & $3 W W 500$ & $3 W M 500$ & - \\
\hline & & 600 mm (23.62 in) & - & - & $3 W S 600$ \\
\hline & & $700 \mathrm{~mm}(27.56 \mathrm{in})$ & $3 W W 700$ & $3 W M 700$ & - \\
\hline & & $800 \mathrm{~mm}(31.5 \mathrm{in})$ & - & - & $3 W S 800$ \\
\hline & & 900 mm (35.43 in) & $3 W W 900$ & $3 W M 900$ & - \\
\hline & \multirow{5}{*}{ 国 } & 500 mm (19.69 in) & - & $3 M M 500$ & $3 M S 500$ \\
\hline & & 600 mm (23.62 in) & - & - & - \\
\hline & & 700 mm (27.56 in) & $3 M W 700$ & $3 M M 700$ & $3 M S 700$ \\
\hline & & 800 mm (31.5 in) & - & $3 M M 800$ & - \\
\hline & & 900 mm (35.43 in) & 3MW900 & 3MM900 & - \\
\hline & \multirow{5}{*}{$\begin{array}{l}\infty \\
\vdots \\
0\end{array}$} & $400 \mathrm{~mm}$ (15.75 in) & - & - & $3 S S 400$ \\
\hline & & 500 mm (19.69 in) & - & $3 S M 500$ & - \\
\hline & & 600 mm (23.62 in) & 3SW600 & - & $3 S S 600$ \\
\hline & & $700 \mathrm{~mm}(27.56 \mathrm{in})$ & - & $3 S M 700$ & $3 S S 700$ \\
\hline & & 800 mm (31.5 in) & $3 S W 800$ & - & - \\
\hline \multirow{15}{*}{ 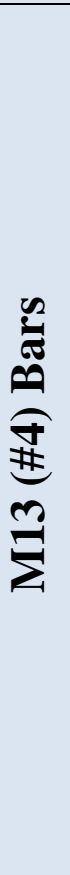 } & \multirow{5}{*}{$\begin{array}{l}\text { चै } \\
\text { కँ }\end{array}$} & 600 mm (23.62 in) & $4 W W 600$ & $4 W M 600$ & 4WS600 \\
\hline & & $700 \mathrm{~mm}$ (27.56 in) & - & - & - \\
\hline & & 800 mm (31.5 in) & $4 W W 800$ & $4 W M 800$ & 4WS800 \\
\hline & & $900 \mathrm{~mm}$ (35.43 in) & - & $4 W M 900$ & - \\
\hline & & 1000 mm (39.37 in) & $4 W W 1000$ & - & - \\
\hline & \multirow{5}{*}{ 国 } & 500 mm (19.69 in) & - & $4 M M 500$ & $4 M S 500$ \\
\hline & & 600 mm (23.62 in) & - & - & - \\
\hline & & 700 mm (27.56 in) & $4 M W 700$ & $4 M M 700$ & $4 M S 700$ \\
\hline & & 800 mm (31.5 in) & - & - & - \\
\hline & & 900 mm (35.43 in) & $4 M W 900$ & $4 M M 900$ & - \\
\hline & \multirow{5}{*}{ 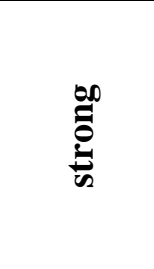 } & $500 \mathrm{~mm}$ (19.69 in) & - & $4 S M 500$ & $4 S S 500$ \\
\hline & & $600 \mathrm{~mm}$ (23.62 in) & 4SW600 & - & $4 S S 600$ \\
\hline & & 700 mm (27.56 in) & - & $4 S M 700$ & $4 S S 700$ \\
\hline & & 800 mm (31.5 in) & 4SW800 & - & - \\
\hline & & 900 mm (35.43 in) & - & $4 S M 900$ & - \\
\hline
\end{tabular}




\subsection{Construction of ICEB Lap Splice Specimens}

As discussed earlier in Section 3.5.3, all specimens were grouted in three grout strength phases. Each grouting phase took approximately 2 hours to mix and grout. To construct the lap splice specimens, ICEB units of the same strength and from the same pressed batch were carefully stacked upside down on elevated spans to specified lengths.

Elevating the specimens allowed for additional rebar to continue past both the top and bottom of the lap splice specimen. The additional $50 \mathrm{~cm}$ (20 inch) extending from both sides of the specimen was used to attach the specimen to the testing apparatus. Lap splice specimens that were grouted with the same grout type (W, M, or S) were stacked next to each other and held together with tie down straps. Due to the interlocking geometry of the ICEB units, specimens were built upside down to ensure grout leakage didn't occur. Plastic sheets were used to separate the specimens so that a bond was not formed between the side grouting channel and the specimen next to it.

On each end of the specimen, approximately $10 \mathrm{~cm}$ (4 in) of rebar was extended out past the top of the grouted specimen. Rebar was tied at this location prior to rebar installation and grouting. The tie was removed before the specimen was tested, allowing for a pure lap splice test without any strength interference of rebar ties. During grouting and curing, the rebar splice was held in place by a small perpendicular rod that was easily removed with the rebar tie before testing. 


\title{
4.4 Grouting of Rebar Lap Splice Specimens
}

\begin{abstract}
All lap splice specimens were fully grouted. Grouting was completed at three and a half ICEB units on the first grouting stage and four ICEB units on subsequent stages per typical construction methods. Grouting half way up the fourth ICEB unit on the first stage ensured a cold joint wasn't present at the ICEB unit boundaries. This method was used until all specimens had been fully grouted. Grout was continuously hand mixed during grouting to avoid particle settling and ensure a uniform consistency of the grout.
\end{abstract}

\subsection{Tested Lap Splice Length $\left(l_{d}\right)$}

The actual lap splice length $\left(l_{d}\right)$ of all specimens is presented in Table 31. The lap splice length was equal to the height of the specimen for all specimens. The actual (measured) lap splice length $\left(l_{d}\right)$ was slightly longer than the nominal lap splice length $\left(l_{p}\right)$. 
Table 31: Tested Lap Splice Length $\left(\boldsymbol{l}_{d}\right)$ of Specimens

\begin{tabular}{|c|c|c|c|c|c|}
\hline \multicolumn{2}{|c|}{ Weak Grouted } & \multicolumn{2}{|c|}{ Medium Grouted } & \multicolumn{2}{|c|}{ Strong Grouted } \\
\hline $\begin{array}{l}\text { Specimen } \\
\text { Name }\end{array}$ & $\begin{array}{l}\text { Actual Lap } \\
\text { Splice } \\
\text { Length }\left(\boldsymbol{l}_{\boldsymbol{d}}\right)\end{array}$ & $\begin{array}{l}\text { Specimen } \\
\text { Name }\end{array}$ & $\begin{array}{c}\text { Actual Lap } \\
\text { Splice } \\
\text { Length } \\
\left(\boldsymbol{l}_{d}\right) \\
\end{array}$ & $\begin{array}{l}\text { Specimen } \\
\text { Name }\end{array}$ & $\begin{array}{c}\text { Tested Lap } \\
\text { Splice } \\
\text { Length }\left(l_{d}\right)\end{array}$ \\
\hline 3WW500 & $\begin{array}{l}502 \mathrm{~mm} \\
\text { (19.8 in) }\end{array}$ & 3WM500 & $\begin{array}{l}506 \mathrm{~mm} \\
\text { (19.9 in) }\end{array}$ & 3WS600 & $\begin{array}{l}606 \mathrm{~mm} \\
(23.9 \mathrm{in})\end{array}$ \\
\hline 3WW700 & $\begin{array}{l}700 \mathrm{~mm} \\
\text { (27.6 in) }\end{array}$ & 3WM700 & $\begin{array}{l}710 \mathrm{~mm} \\
\text { (27.9 in) }\end{array}$ & 3WS800 & $\begin{array}{l}847 \mathrm{~mm} \\
\text { (33.3 in) }\end{array}$ \\
\hline 3WW900 & $\begin{array}{l}905 \mathrm{~mm} \\
\text { (35.6 in) }\end{array}$ & 3WM900 & $\begin{array}{l}905 \mathrm{~mm} \\
\text { (35.6 in) }\end{array}$ & 3MS500 & $\begin{array}{l}505 \mathrm{~mm} \\
\text { (19.9 in) }\end{array}$ \\
\hline 3MW700 & $\begin{array}{l}700 \mathrm{~mm} \\
\text { (27.6 in) }\end{array}$ & 3MM500 & $\begin{array}{l}506 \mathrm{~mm} \\
\text { (19.9 in) }\end{array}$ & 3MS700 & $\begin{array}{l}711 \mathrm{~mm} \\
\text { (28.0 in) }\end{array}$ \\
\hline 3MW900 & $\begin{array}{l}903 \mathrm{~mm} \\
\text { (35.6 in) }\end{array}$ & 3MM700 & $\begin{array}{l}705 \mathrm{~mm} \\
\text { (27.8 in) }\end{array}$ & 3SS400 & $\begin{array}{l}405 \mathrm{~mm} \\
\text { (15.9 in) }\end{array}$ \\
\hline 3SW600 & $\begin{array}{l}606 \mathrm{~mm} \\
(23.9 \mathrm{in})\end{array}$ & 3MM800 & $\begin{array}{l}811 \mathrm{~mm} \\
\text { (31.9 in) }\end{array}$ & $3 S S 600$ & $\begin{array}{l}610 \mathrm{~mm} \\
(24.0 \mathrm{in})\end{array}$ \\
\hline 3SW800 & $\begin{array}{l}810 \mathrm{~mm} \\
\text { (31.9 in) }\end{array}$ & 3MM900 & $\begin{array}{l}900 \mathrm{~mm} \\
(35.4 \mathrm{in})\end{array}$ & $3 S S 700$ & $\begin{array}{l}714 \mathrm{~mm} \\
\text { (28.1 in) }\end{array}$ \\
\hline 4WW600 & $\begin{array}{l}606 \mathrm{~mm} \\
\text { (23.9 in) }\end{array}$ & 3SM500 & $\begin{array}{l}508 \mathrm{~mm} \\
\text { (20.0 in) }\end{array}$ & 4WS600 & $\begin{array}{l}608 \mathrm{~mm} \\
(23.9 \mathrm{in})\end{array}$ \\
\hline 4WW800 & $\begin{array}{l}813 \mathrm{~mm} \\
\text { (32.0 in) }\end{array}$ & 3SM700 & $\begin{array}{l}705 \mathrm{~mm} \\
(27.8 \mathrm{in})\end{array}$ & 4WS800 & $\begin{array}{l}811 \mathrm{~mm} \\
\text { (31.9 in) }\end{array}$ \\
\hline 4WW1000 & $\begin{array}{l}1003 \mathrm{~mm} \\
\text { (39.5 in) }\end{array}$ & 4WM600 & $\begin{array}{l}616 \mathrm{~mm} \\
(24.3 \mathrm{in})\end{array}$ & 4MS500 & $\begin{array}{l}511 \mathrm{~mm} \\
\text { (20.1 in) }\end{array}$ \\
\hline 4MW700 & $\begin{array}{l}708 \mathrm{~mm} \\
\text { (27.9 in) }\end{array}$ & 4WM800 & $\begin{array}{l}806 \mathrm{~mm} \\
\text { (31.8 in) }\end{array}$ & 4MS700 & $\begin{array}{l}705 \mathrm{~mm} \\
\text { (27.8 in) }\end{array}$ \\
\hline 4MW900 & $\begin{array}{l}902 \mathrm{~mm} \\
\text { (35.5 in) }\end{array}$ & 4WM900 & $\begin{array}{l}908 \mathrm{~mm} \\
\text { (35.8 in) }\end{array}$ & 4SS500 & $\begin{array}{l}502 \mathrm{~mm} \\
(19.8 \mathrm{in})\end{array}$ \\
\hline 4SW600 & $\begin{array}{l}651 \mathrm{~mm} \\
(25.6 \mathrm{in})\end{array}$ & 4MM500 & $\begin{array}{l}508 \mathrm{~mm} \\
(20.0 \mathrm{in})\end{array}$ & 4SS600 & $\begin{array}{l}610 \mathrm{~mm} \\
(24.0 \mathrm{in})\end{array}$ \\
\hline 4SW800 & $\begin{array}{l}813 \mathrm{~mm} \\
\text { (32.0 in) }\end{array}$ & 4MM700 & $\begin{array}{l}699 \mathrm{~mm} \\
(27.5 \mathrm{in})\end{array}$ & 4SS700 & $\begin{array}{l}705 \mathrm{~mm} \\
(27.8 \mathrm{in})\end{array}$ \\
\hline & & 4MM900 & $\begin{array}{l}903 \mathrm{~mm} \\
\text { (35.6 in) }\end{array}$ & & \\
\hline & & 4SM500 & $\begin{array}{l}532 \mathrm{~mm} \\
(20.9 \mathrm{in})\end{array}$ & & \\
\hline & & 4SM700 & $\begin{array}{l}705 \mathrm{~mm} \\
(27.8 \mathrm{in})\end{array}$ & & \\
\hline & & 4SM900 & $\begin{array}{l}886 \mathrm{~mm} \\
(34.9 \mathrm{in})\end{array}$ & & \\
\hline
\end{tabular}




\subsection{ICEB Lap Splice Test Set Up}

An apparatus was designed to measure total displacement of the specimen. It was attached as close to the top and bottom of each specimen as possible to measure the rebar displacement inside the specimen. Two LVDTs were placed at opposite and equal distances from the center of the bottom of the specimen to measure displacement during testing (Figure 26). The testing machine measured the total displacement and maximum tensile capacity of each lap splice specimen.
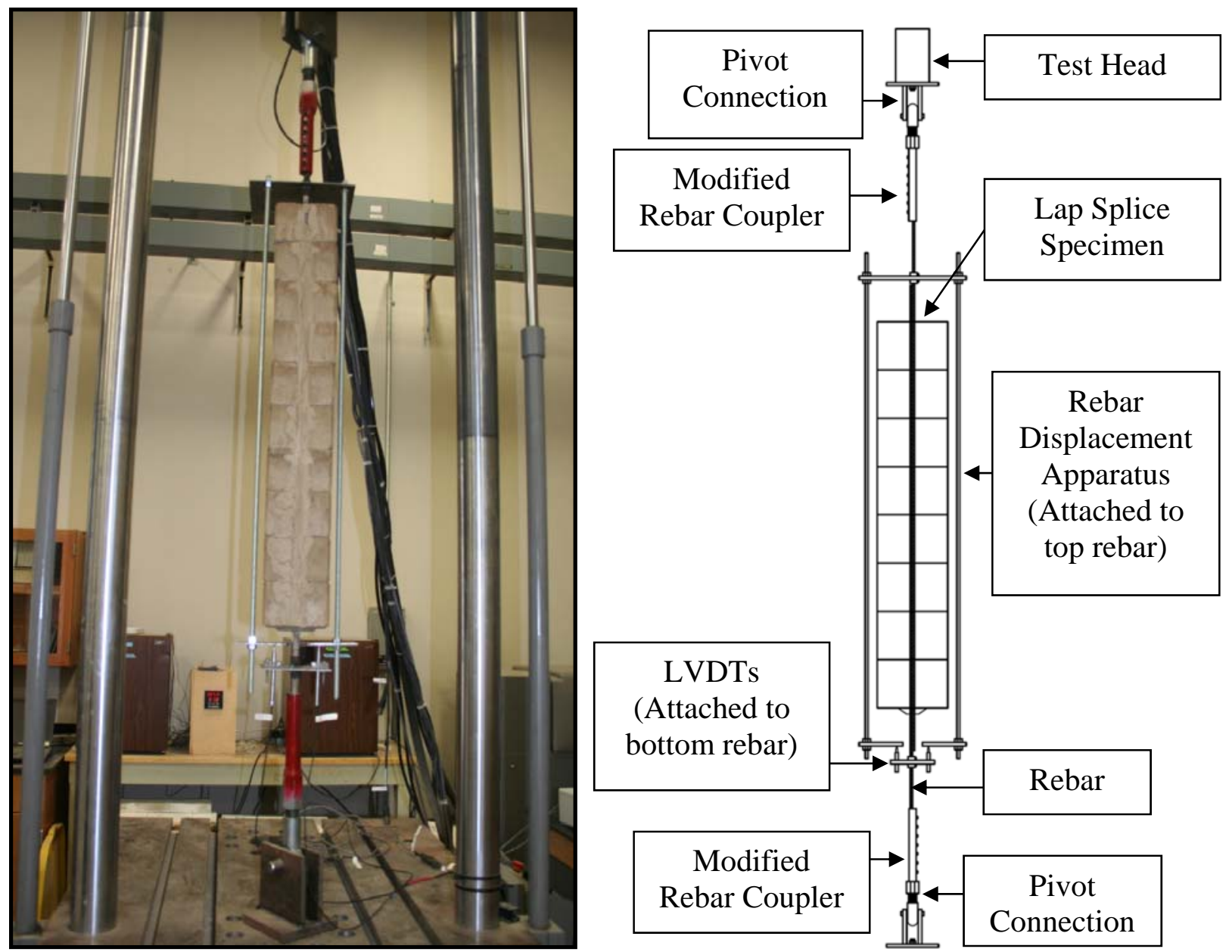

Figure 26: Typical Installation, Specimen 4WW1000 (left) and Illustration (right) 


\subsection{Modification of Rebar Couplers}

Two identical rebar couplers were modified to transfer and withstand the high tensile forces during testing. The coupler was constructed by altering a Bar Lock ${ }^{\circledR}$ coupler (Figure 27) donated from Dayton Superior. Bar Lock ${ }^{\circledR}$ couplers are typically embedded in reinforced concrete to mechanically tie rebar. The end of the coupler was welded to a threaded long nut that allowed the coupler to attach to a threaded rod (Figure 30).

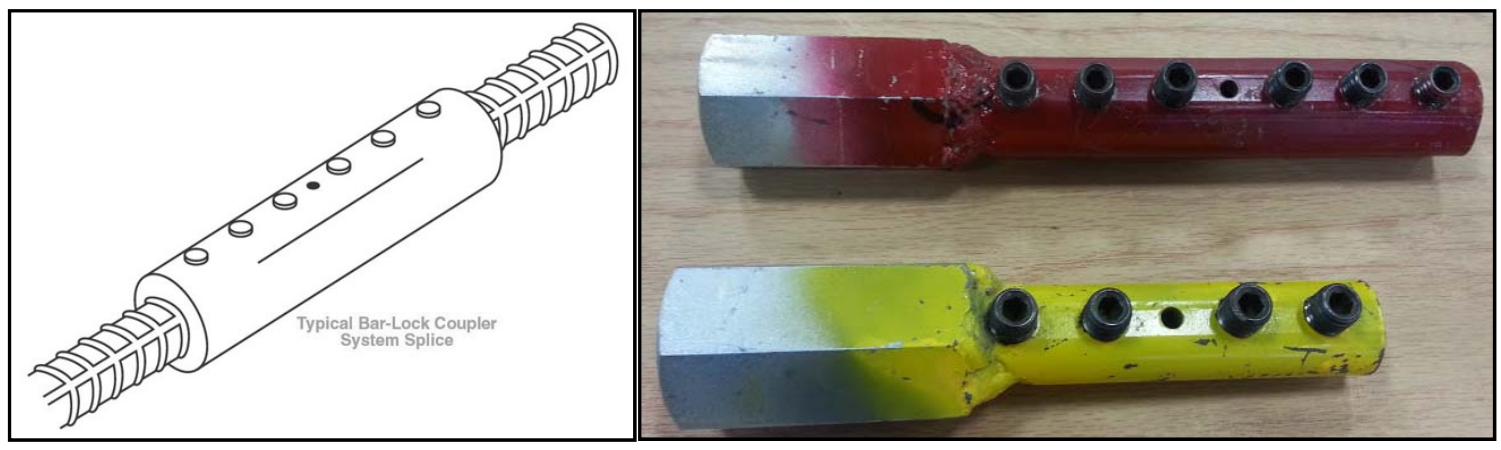

Figure 27: Dayton Bar Lock ${ }^{\circledR}$ Coupler from the Dayton Online Catalog (2011) (left) and Welded Couplers for Sizes \#3 (yellow) and \#4 (red) Rebar (right) 
The coupler attached and held the rebar with steel setscrews. The rebar coupler apparatus was used to attach the rebar to both the top and bottom of the test machine (Figure 28).

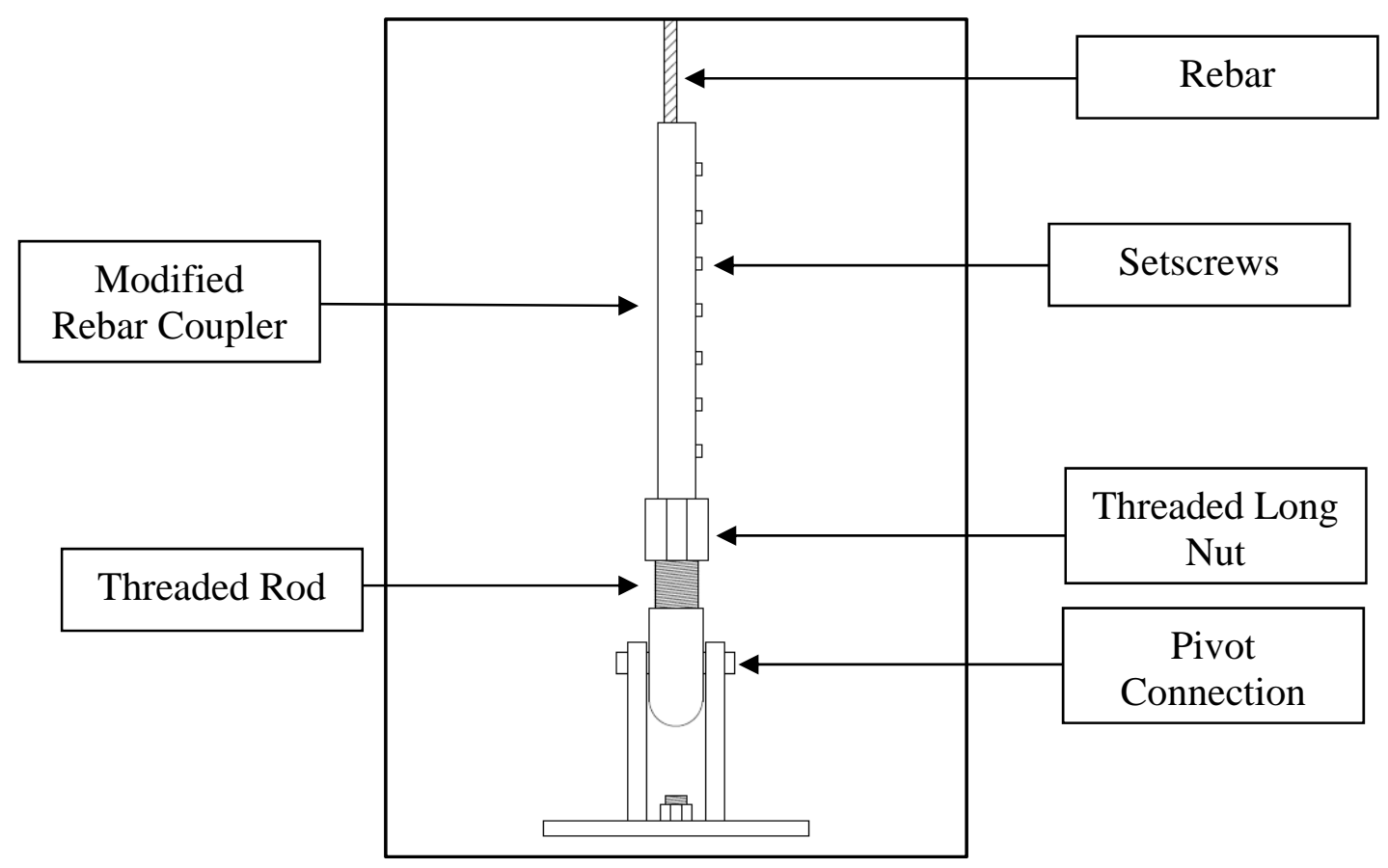

Figure 28: Rebar Coupler Illustration

The system performed well even as high tensile forces caused some rebar in specimens to yield. The rebar for specimen 3 SS700 stripped during testing within the coupler attachment. The test was stopped to reattach the specimen and restarted. The rebar had yielded significantly and experienced strain hardening prior to stripping (Figure 29).

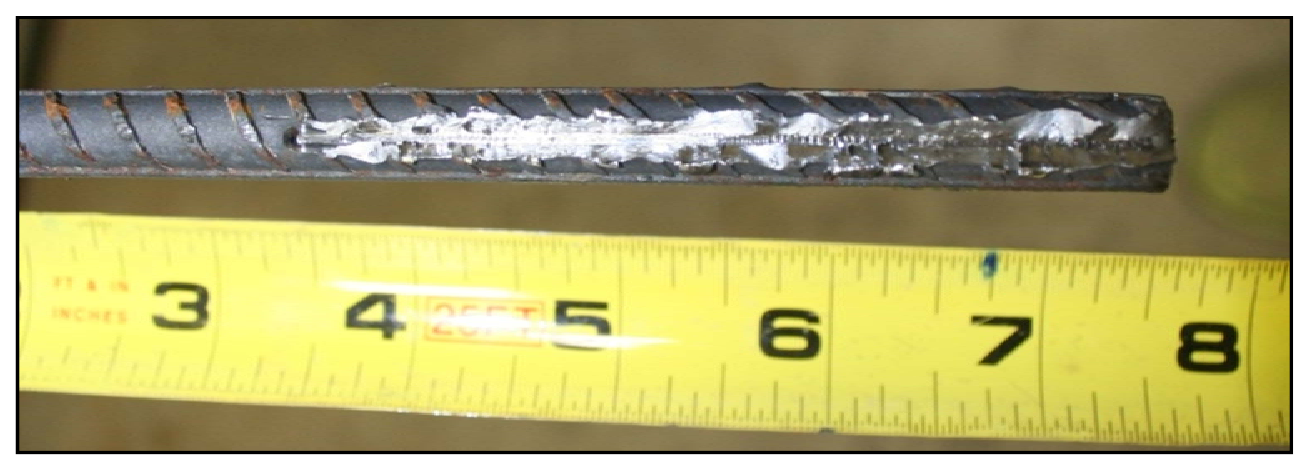

Figure 29: Stripped Rebar from 3SS700 Specimen 


\subsubsection{Installation of Lap Splice Specimens}

The lap splice specimens were tensile tested vertically, in the direction they were constructed, grouted, and cured. Specimens were attached to the top coupler with set

screws and hydraulically lowered into the bottom coupler and attached. The position of the bottom coupler was adjusted to mitigate the potential effects of eccentricity on the installed lap splice specimen. The LVDT apparatus, installed to measure the rebar displacement within the specimen, was added prior to loading the specimen 


\subsubsection{Rebar Eccentricity}

The eccentricity of the rebar had no observable effects on most lap splice specimens. However, for some stronger specimens, additional stresses may have been created due to the slight eccentricity of the single lap splice system. In these specimens, a slight gap between rebar lap splices was observed at the top and bottom of the specimen after the specimen had experienced significant strain hardening (Figure 30).

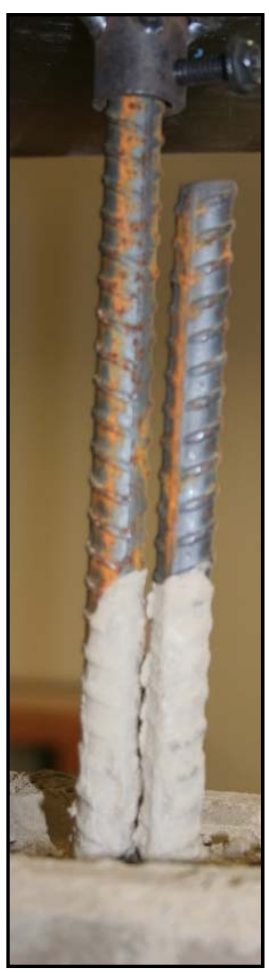

Figure 30: Effects of Rebar Eccentricity on Specimen 4SM700 


\subsection{ICEB Lap Splice Specimen Testing}

All lap splice tests ran at constant rate of $0.04 \mathrm{in} / \mathrm{min}$ until failure. Specimens that did not experience rebar yielding were tested to failure in approximately 10 minutes. Specimens that experienced rebar yielding took longer to test to failure (approximately 20 minutes). Specimens that showed obvious signs of yielding had loading rates increased during testing.

\subsection{Typical Failure Modes of Lap Splice Specimens}

Two failure modes were observed during specimen testing; the splitting of grout and masonry and the pull out of reinforcement rebar. In shorter samples constructed with stronger materials, the splitting of grout and masonry tended to be an explosive failure with an immediate loss of tensile stress. Longer specimens that failed due to the pull out of the reinforcement rebar experienced a more gradual loss of tensile stress and no sign of ICEB unit cracking. 


\subsubsection{Splitting of Grout and Masonry Failure}

Shorter lap splice specimens typically failed laterally along the ICEB unit/grout interface

(Figure 31). A loud and audible cracking noise was observed during the lateral failure of stronger specimens. Splitting cracks often initated at the top of the speceimen and propegated out along the ICEB unit/grout interface. A crack expanding from the lap splice specimen 3MS500 is shown below in Figure 31.

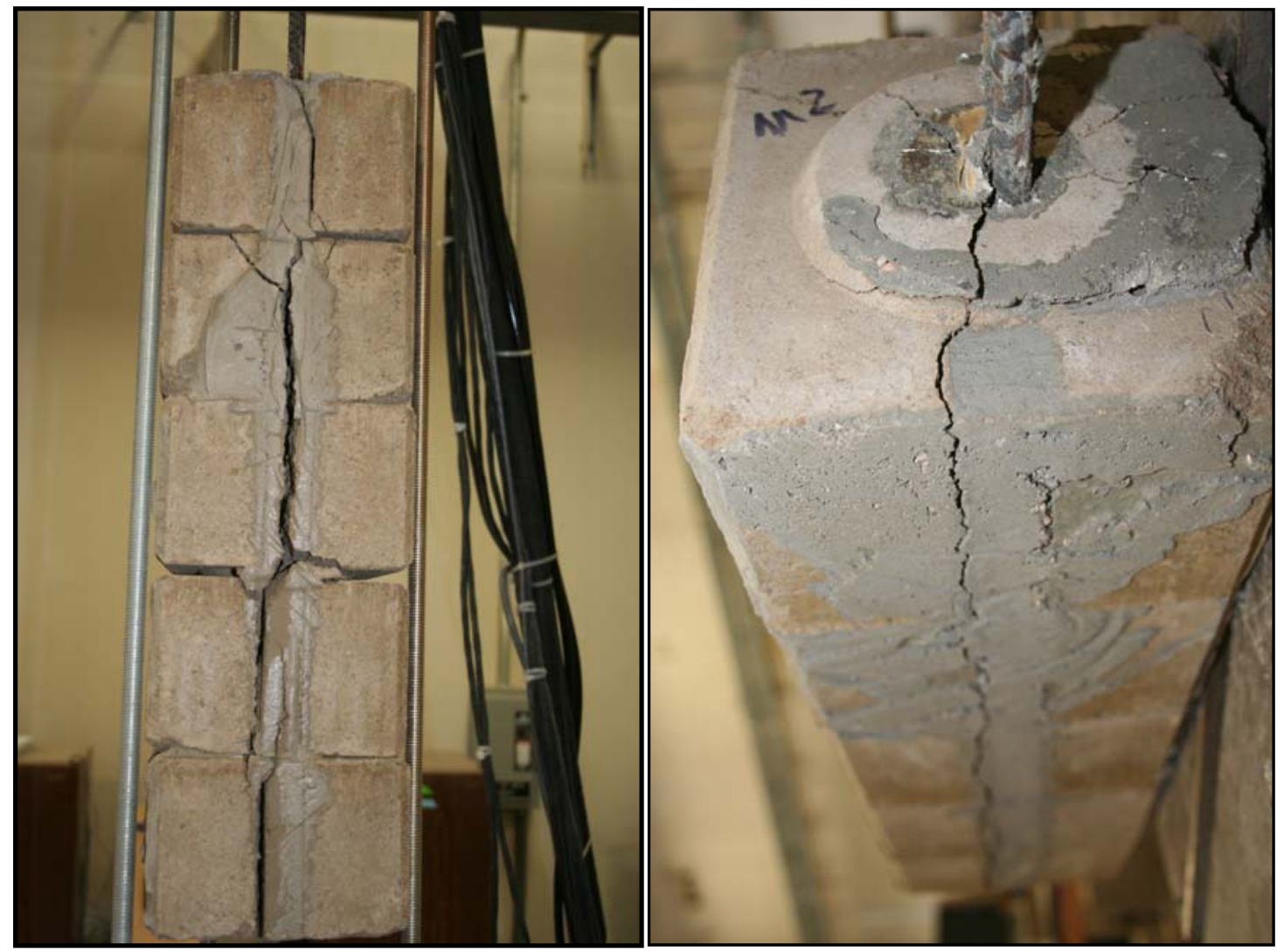

Figure 31: Typical Longitudinal Failure Mode of ICEB Lap Splice Specimens (left) and Propagation of Top Crack along ICEB unit/Grout Interface (right) 
Rebar tensile forces are resisted and transferred by the bond strength of the reinforcing steel and the grout. The bond strength is derived from the chemical adhesion of the bar and grout, the friction along the surface of the bar, and the mechanical interaction between the surface of the bar and the surrounding grout (Hammons et al. 1994). Soon after the rebar begins to slip the chemical adhesion is broken and provides little resistance to the radial force (Lutz and Gregory 1967). After the chemical adhesion is broken, the primary resistance force is the baring of the rebar ribs against the grout or concrete (Hammons et al. 1994). The longitudinal splitting of the specimen is induced by a radial stress created from the tensile force of the rebar (Figure 32).

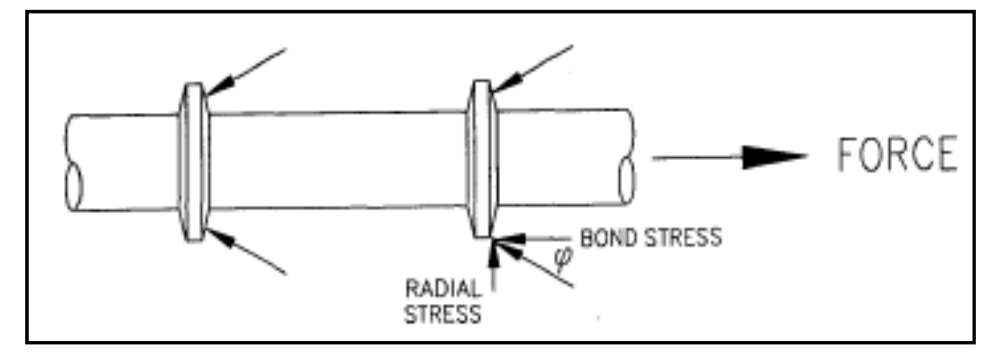

Figure 32: Radial Stresses Developed Against Grout from Tensile Force from Hammons et al. 1994 
The resulting radial stress leads to the transverse movement of the reinforcement rebar (Figure 33 ). Longitudinal cracks occur when the radial tensile forces exceed the tensile capacity of the grout (Hammons et al. 1994) (Figure 33).

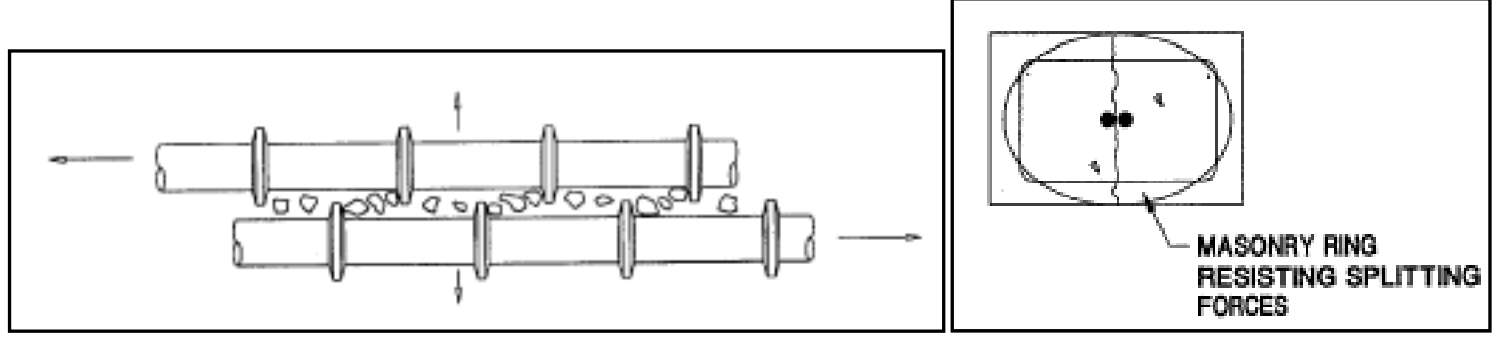

Figure 33: Lateral Splitting Forces Developed during Lap Splice Testing from Hammons et al. (1994) (left) and Longitudinal Crack Development at Top of Block from Hammons et al. (1994) 


\subsubsection{Pull-out of Reinforcement Bar}

Reinforcing rebar pullout was identified as the failure method for nearly all specimens that contained weak grout. During failure, the weak grouted specimens experienced a sudden loss of tensile strength as the rebar lap splices slipped past each other with no observable sign of specimen cracking or rebar yielding. ICEB unit uplifting was typically observed during rebar pull-out failure as the top ICEB units were still bonded to the reinforcing rebar (Figure 34).

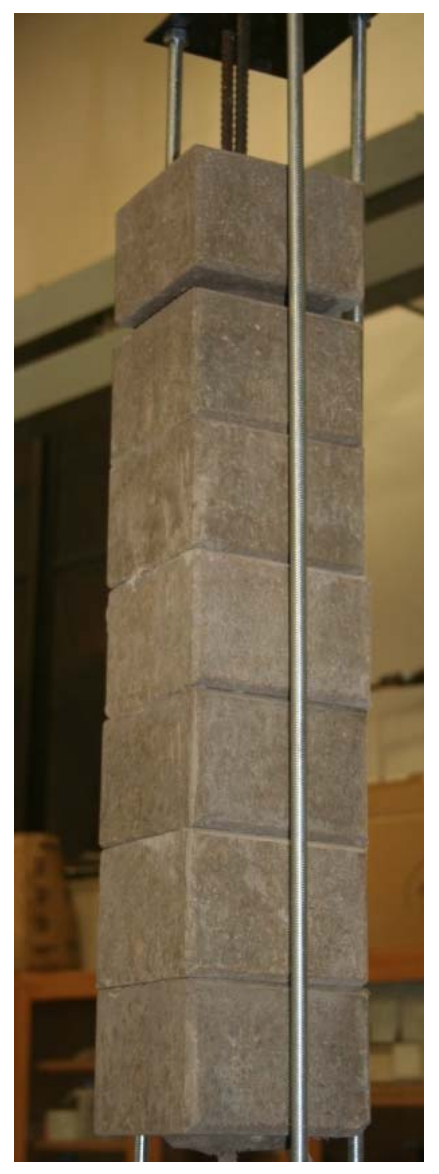

Figure 34: Pull Out Failure of Rebar Lap Splice and Top ICEB Unit Uplift on Specimen 3SM700. 


\subsection{Yielding of Lap Splice Reinforcing Rebar}

No lap splice specimen achieved tensile strengths equal or greater to that of the ultimate strength of the rebar $\left(f_{u}\right)$. However, several specimens achieved tensile strengths greater than that of the yield strength of the rebar $\left(f_{y}\right)$. The following specimens in Table 32 were observed to have yielded during testing.

Table 32: Summary of Yielding Lap Splice Specimens

\begin{tabular}{|c|c|c|c|}
\hline $\begin{array}{l}\text { Specimen } \\
\text { Name }\end{array}$ & $\begin{array}{c}\text { Rebar } \\
\text { Size }\end{array}$ & $\begin{array}{l}\text { Grout } \\
\text { Type }\end{array}$ & Figure Number \\
\hline 3MS700 & \multirow{7}{*}{ M10 (\#3) } & \multirow{7}{*}{ Strong } & \multirow{7}{*}{$\begin{array}{l}\text { (1) Specimen 3S5700A } \\
\text { slipped during testing. (2) } \\
\text { Specimen 3SS700A was } \\
\text { retested and data was } \\
\text { recorded as Specimen } \\
\text { 3SS700B. } \\
\text { Figure } 35\end{array}$} \\
\hline 3WS800 & & & \\
\hline $3 S S 600$ & & & \\
\hline $3 S S 400$ & & & \\
\hline $3 S S 600$ & & & \\
\hline $3 \mathrm{SS}^{2} 700 \mathrm{~A}^{1}$ & & & \\
\hline $3 S 5700 B^{2}$ & & & \\
\hline $4 S S 500$ & \multirow{3}{*}{ M13 (\#4) } & \multirow{3}{*}{ Strong } & \multirow{3}{*}{ Figure 36} \\
\hline 4SS600 & & & \\
\hline 4SS700 & & & \\
\hline 3SM700 & M10 (\#3) & Medium & Figure 37 \\
\hline 4SM700 & \multirow{2}{*}{ M13 (\#4) } & \multirow{2}{*}{ Medium } & \multirow{2}{*}{ Figure 38} \\
\hline 4SM900 & & & \\
\hline $\mathrm{N} / \mathrm{A}^{3}$ & M10 (\#3) & Weak & Figure 39 \\
\hline$N / A^{3}$ & M13 (\#4) & Weak & Figure 40 \\
\hline
\end{tabular}

(1) Specimen 3SS700A slipped during testing

(2) Specimen 3SS700A was retested and data was recorded as Specimen 3SS700B

(3) No weak grouted specimens yielded during testing. 


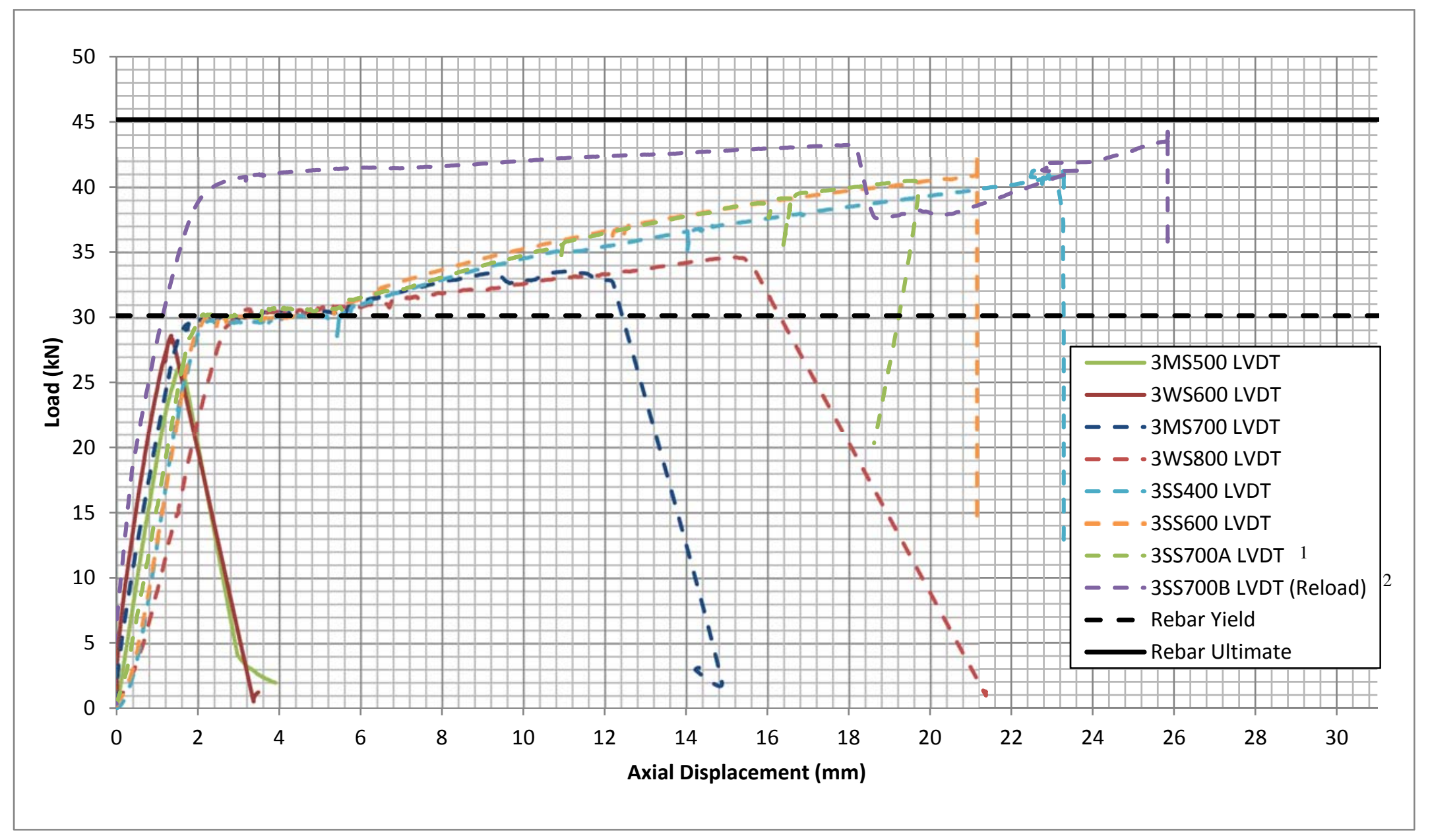

(1) Specimen 3SS700A slipped during testing. (2) Specimen 3SS700A was retested and data was recorded as Specimen 3SS700B.

Figure 35: Axial Displacement vs. Load for Strong Grouted M10 (\#3 bar) Lap Splice Specimens 


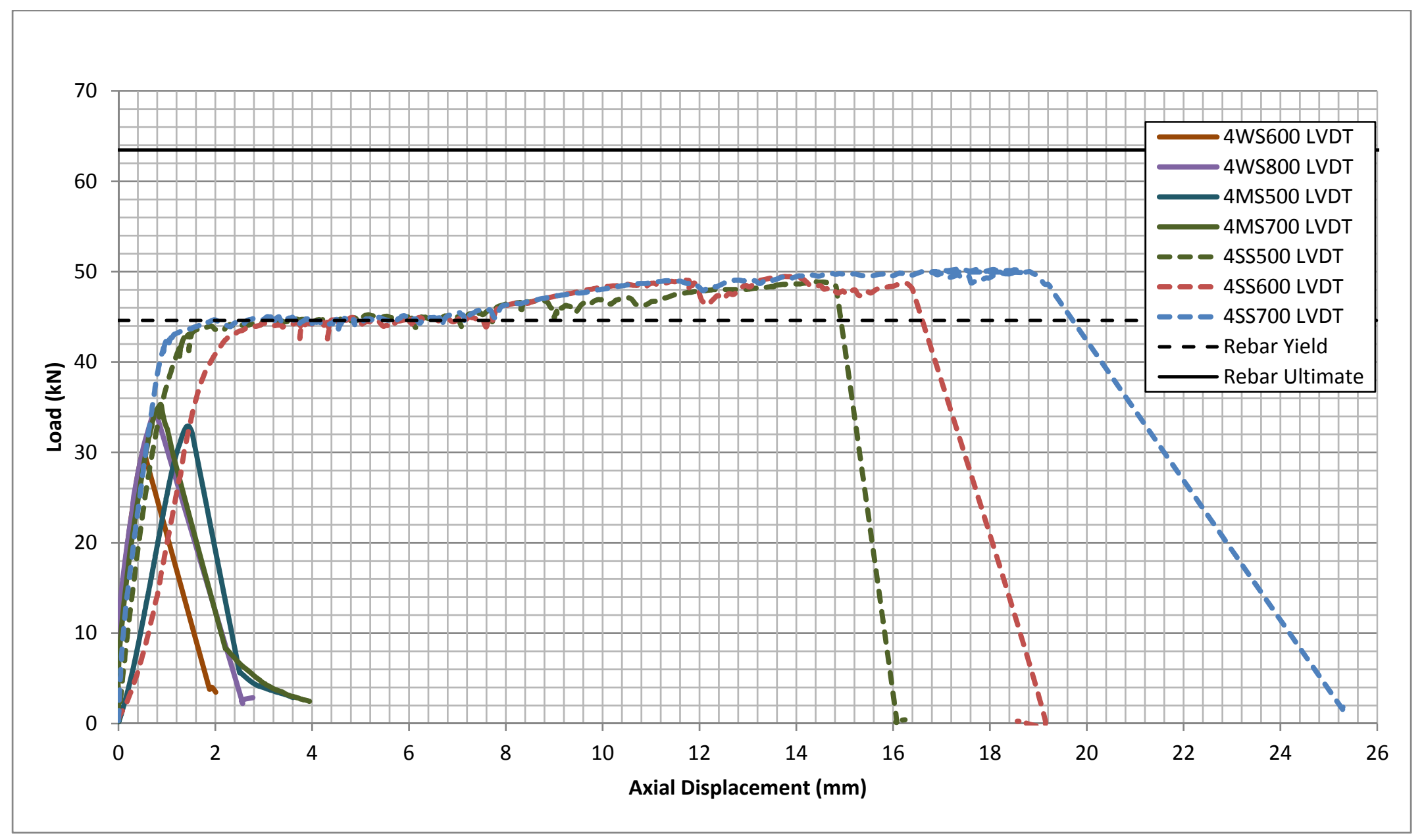

Figure 36: Axial Displacement vs. Load for Strong Grouted M13 (\#4 bar) Lap Splice Specimens 


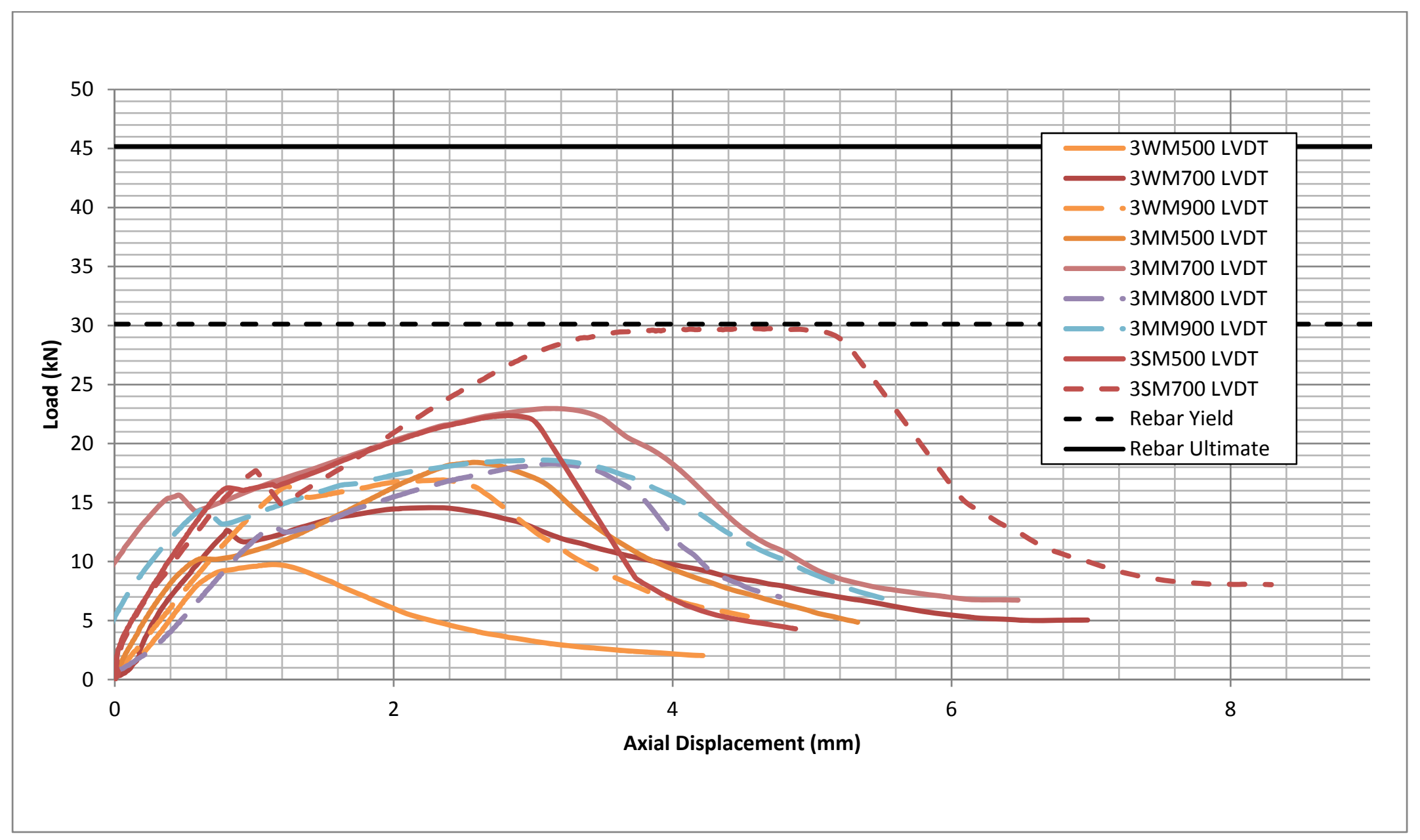

Figure 37: Axial Displacement vs. Load for Medium Grouted M10 (\#3 bar) Lap Splice Specimens 


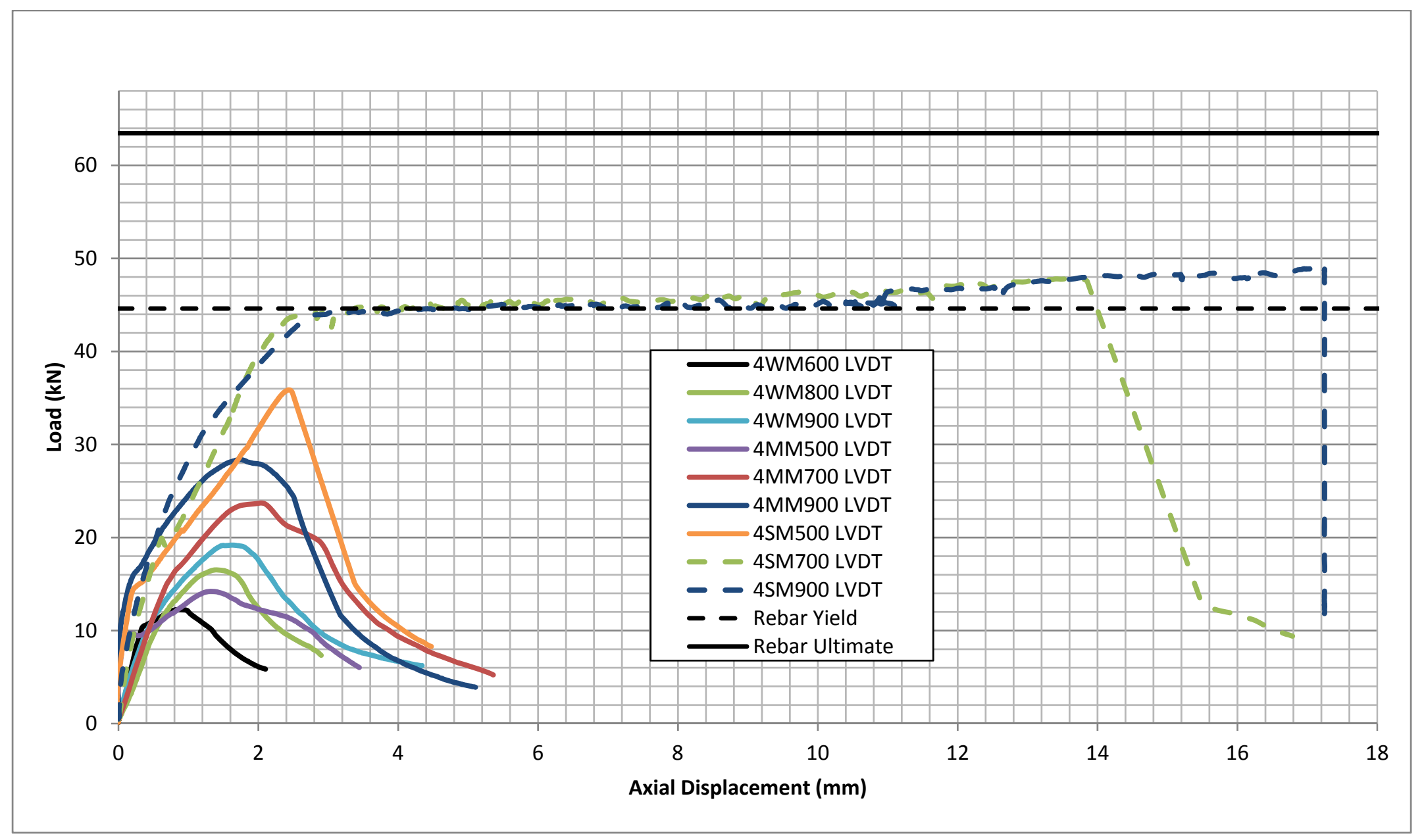

Figure 38: Axial Displacement vs. Load for Medium Grouted M13 (\#4 bar) Lap Splice Specimens 


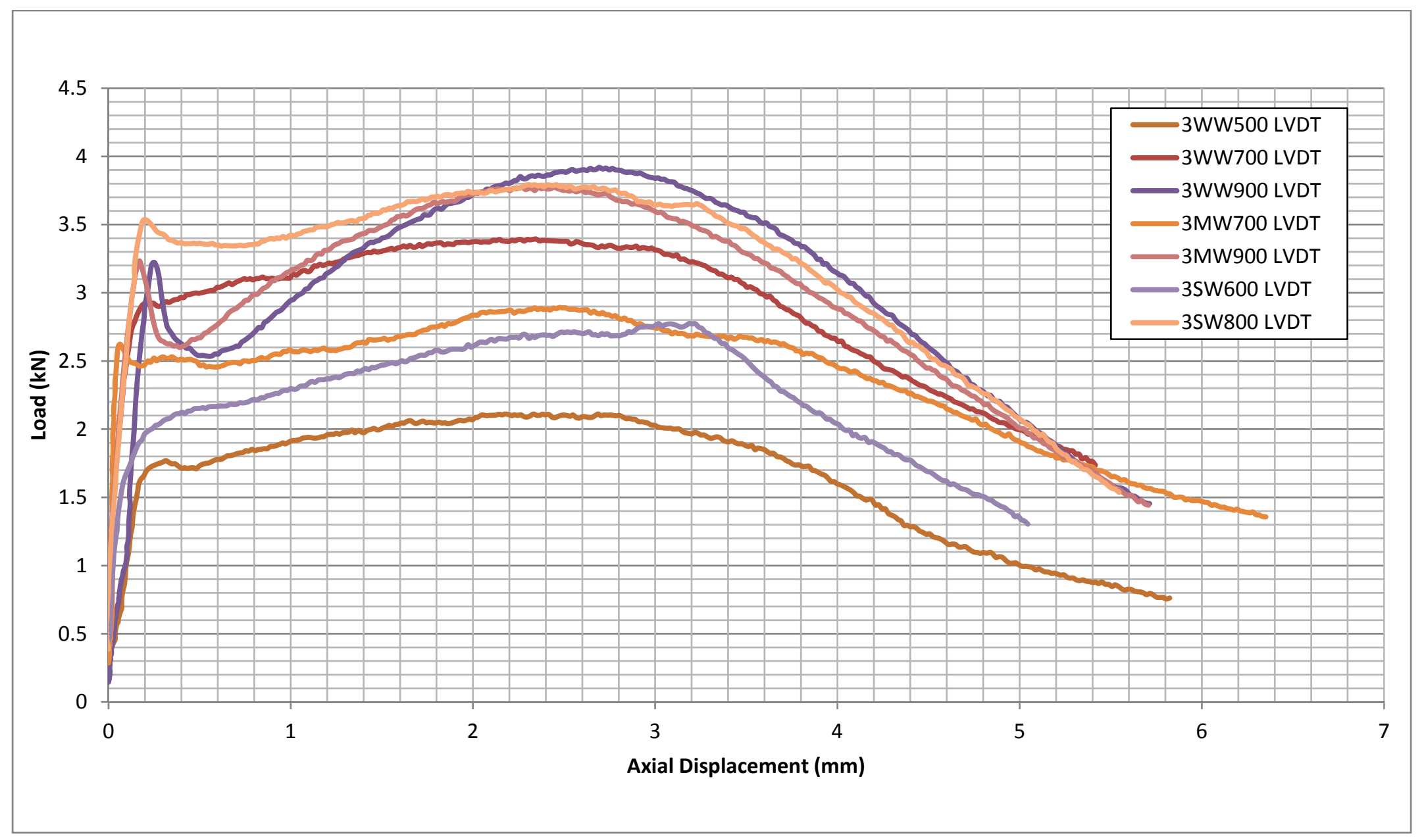

Figure 39: Axial Displacement vs. Load for Weak Grouted M10 (\#3 bar) Lap Splice Specimens 


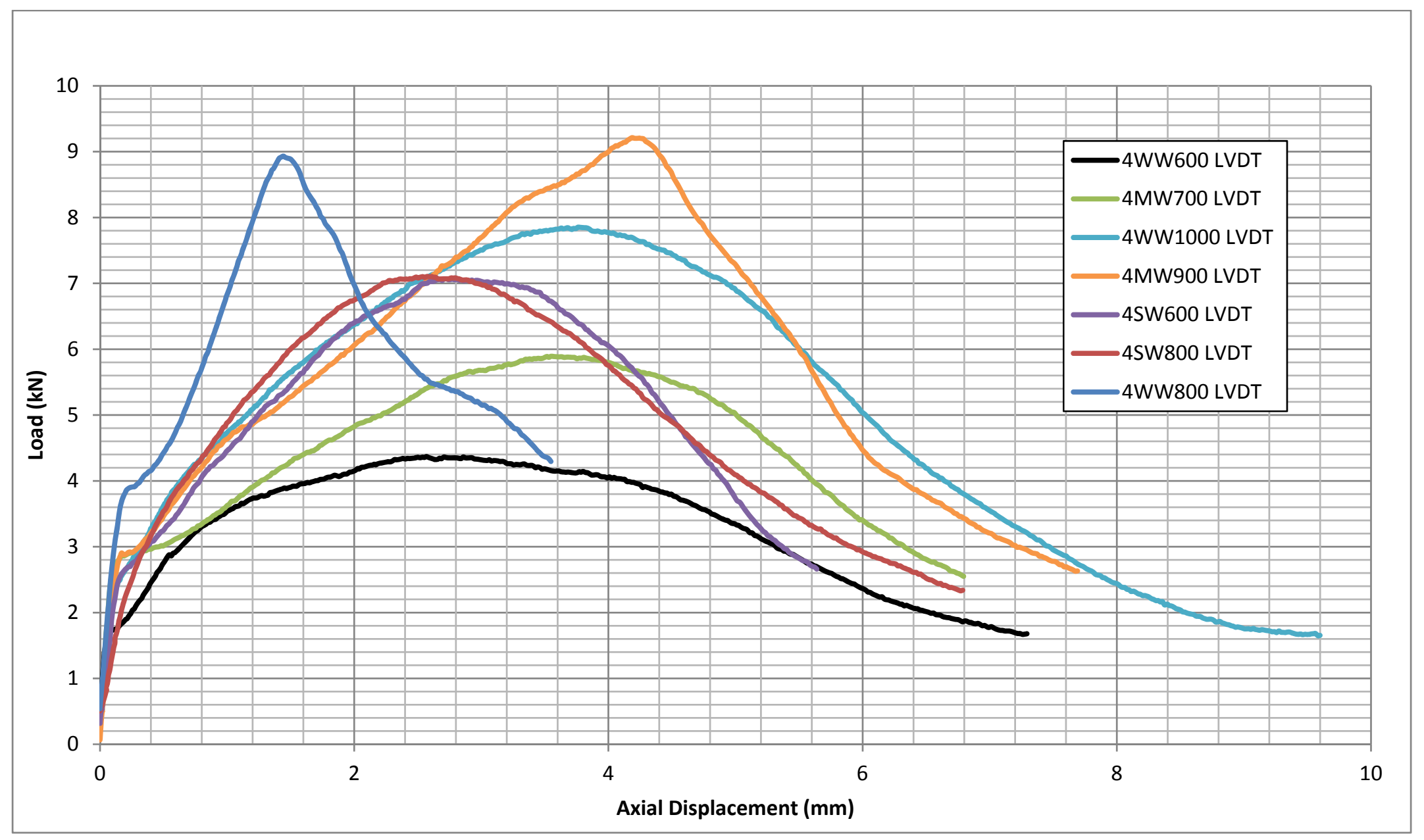

Figure 40: Axial Displacement vs. Load for Weak Grouted M13 (\#4 bar) Lap Splice Specimens 


\section{LAP SPLICE EXPERIMENTAL RESULTS AND ANALYSIS}

\subsection{MSJC Lap Splice Strength Prediction Equation vs Measured ICEB Lap Splice Strength}

The MSJC lap splice strength prediction model (Equation 1.3) was used to predict the lap splice tensile capacity of the tested ICEB lap splice specimens. The MSJC lap splice strength predictions were compared against the measured ICEB lap splice strengths (See Table 35 and Table 36 in Appendix B). The MSJC equation was not accurate in predicting the measured ICEB lap splice strengths. The MSJC model over-predicted the lap splice strength of nearly all measured specimens by an average of $70 \%$. The model was particularly poor in predicting the ICEB lap splice strength of specimens constructed from weaker materials. The materials tested in the modeling of the MSJC equation were stronger than the materials tested in this research, so it is possible that the MSJC equation may not be applicable for lap splices constructed from weaker ICEB materials. The

discrepancy between the MSJC strength prediction equation and the measured strength of the ICEB lap splice specimen may also be caused by the less than adequate ICEB rebar cover distance, as defined by the MSJC. All lap splices in this research exceeded the MSJC maximum standard of 8 percent (See Section 3.8.1). 
The MSJC prediction equation was less accurate in predicting the measured strength of specimens constructed from weaker grout. Figure 41 provides a graphical representation of the comparison and is separated by grout type to demonstrate how the measured strength of the ICEB lap splice specimen significantly varied in its relationship to the predicted strength calculated from the MSJC equation. The MSJC equation did not sufficiently factor the strength of the grout used to construct ICEB lap splice specimens. Lap splice specimens that yielded during testing are included in the graph as data points for comparison purposes and were not included in the evaluation of the MSJC equation as the failure mode of these specimens were governed by the strength of the rebar and not the lap splice strength.

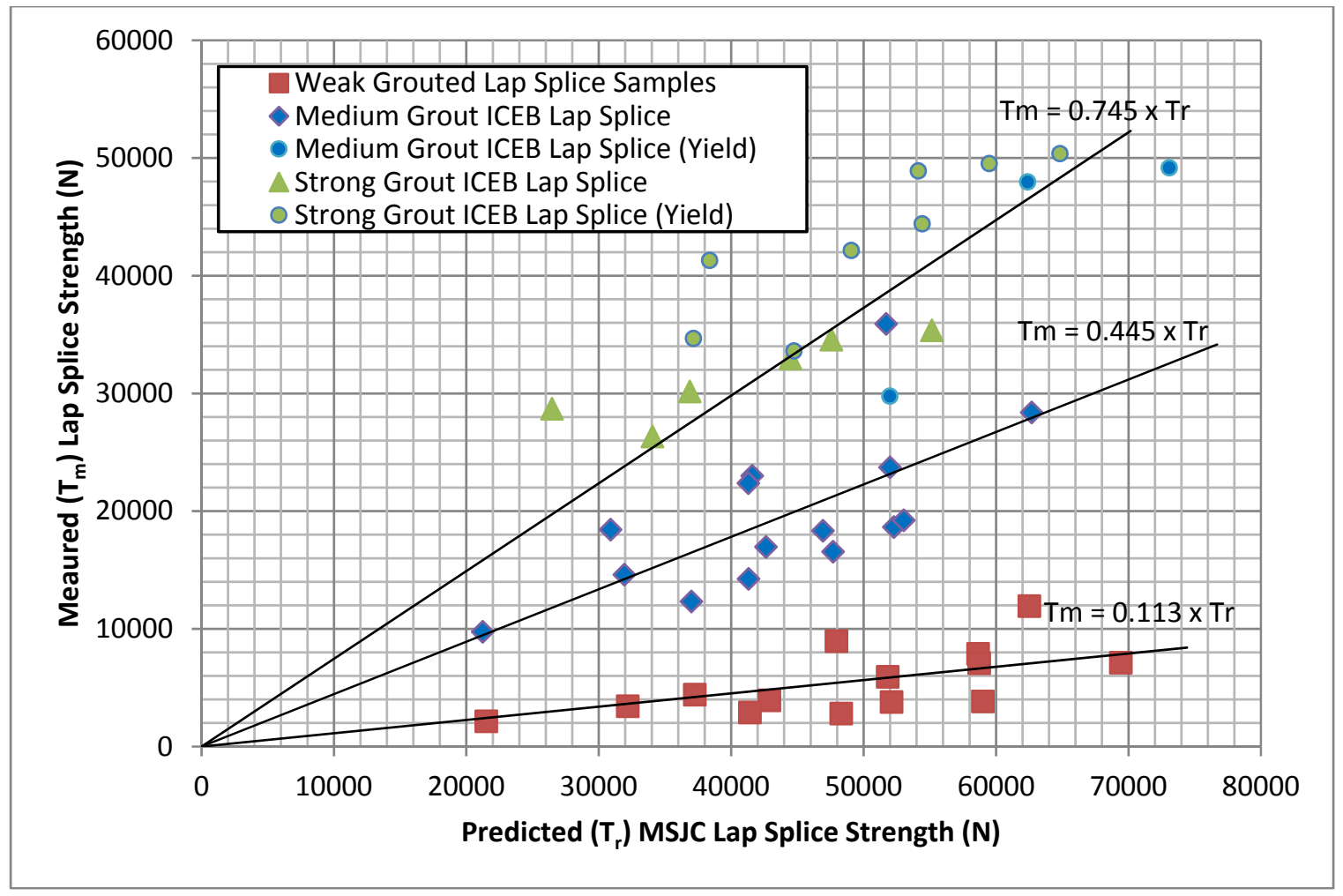

Figure 41: Predicted MSJC Lap Splice Strength $\left(T_{r}\right)$ vs. Measured Lap Splice Strength $\left(T_{m}\right)$ 


\subsection{Measured ICEB Lap Splice Strength $\left(T_{m}\right)$ vs. ICEB Unit Strength $\left(\boldsymbol{f}^{\prime}{ }_{b}\right)$}

For lap splice specimens constructed out of medium and strong strength grout, the strength of a lap splice specimen $\left(T_{m}\right)$ was generally improved with a stronger ICEB unit $\left(f^{\prime}{ }_{b}\right)$ (Figure 42 and Figure 43). However, for lap splice specimens constructed from weak strength grout, the strength of the lap splice $\left(T_{m}\right)$ was not affected by the strength of the ICEB unit $\left(f^{\prime}{ }_{b}\right)$. Stronger ICEB units did not improve the lap splice strength for specimens constructed from weak grout. For specimens that experienced yielding, the strength of the lap splice was controlled by the tensile capacity of the rebar (Figure 43).

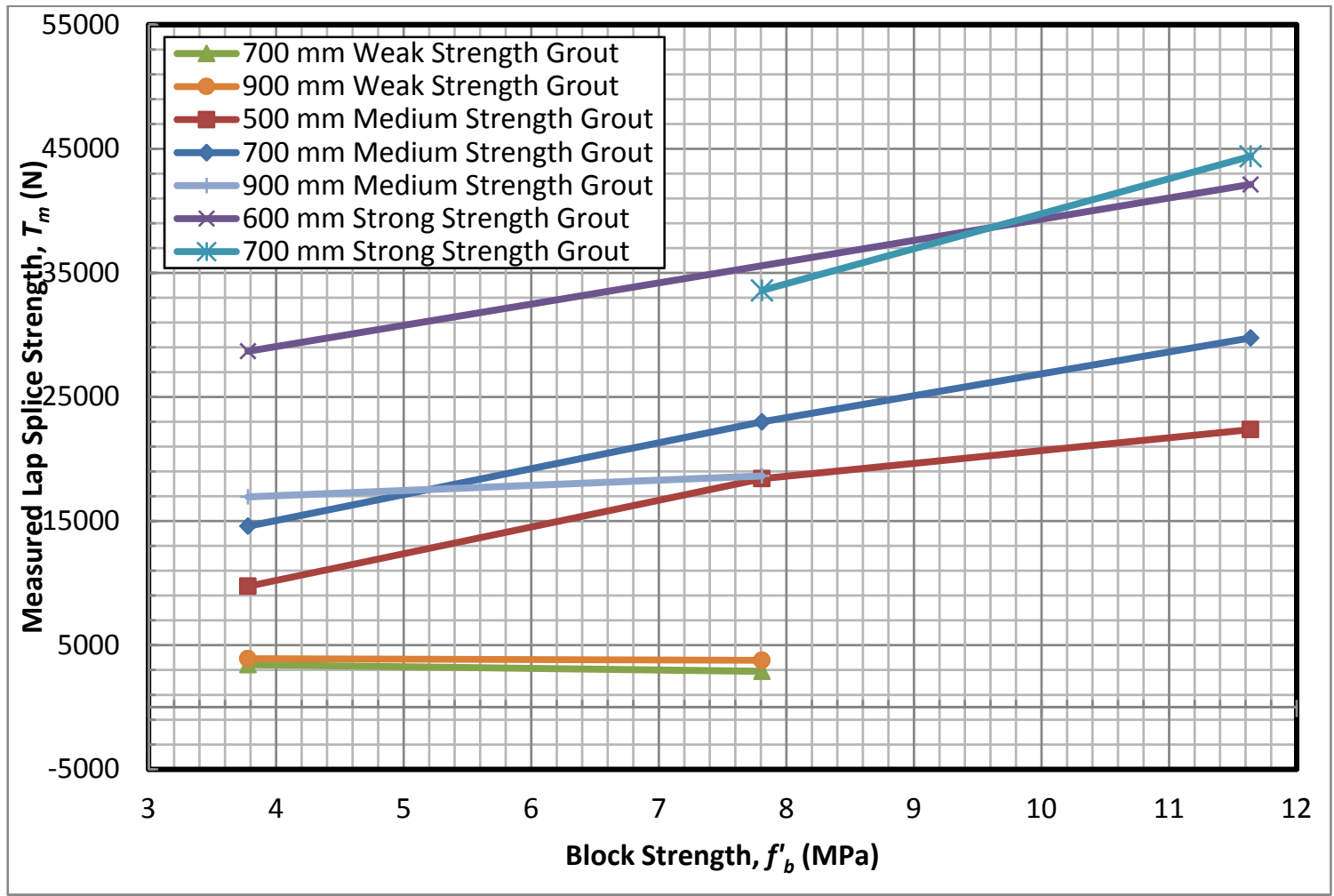

Figure 42: Measured Lap Splice Strength $\left(T_{m}\right)$ of \#3 sized bar vs. ICEB Unit Strength $\left(f^{\prime}{ }_{b}\right)$ 


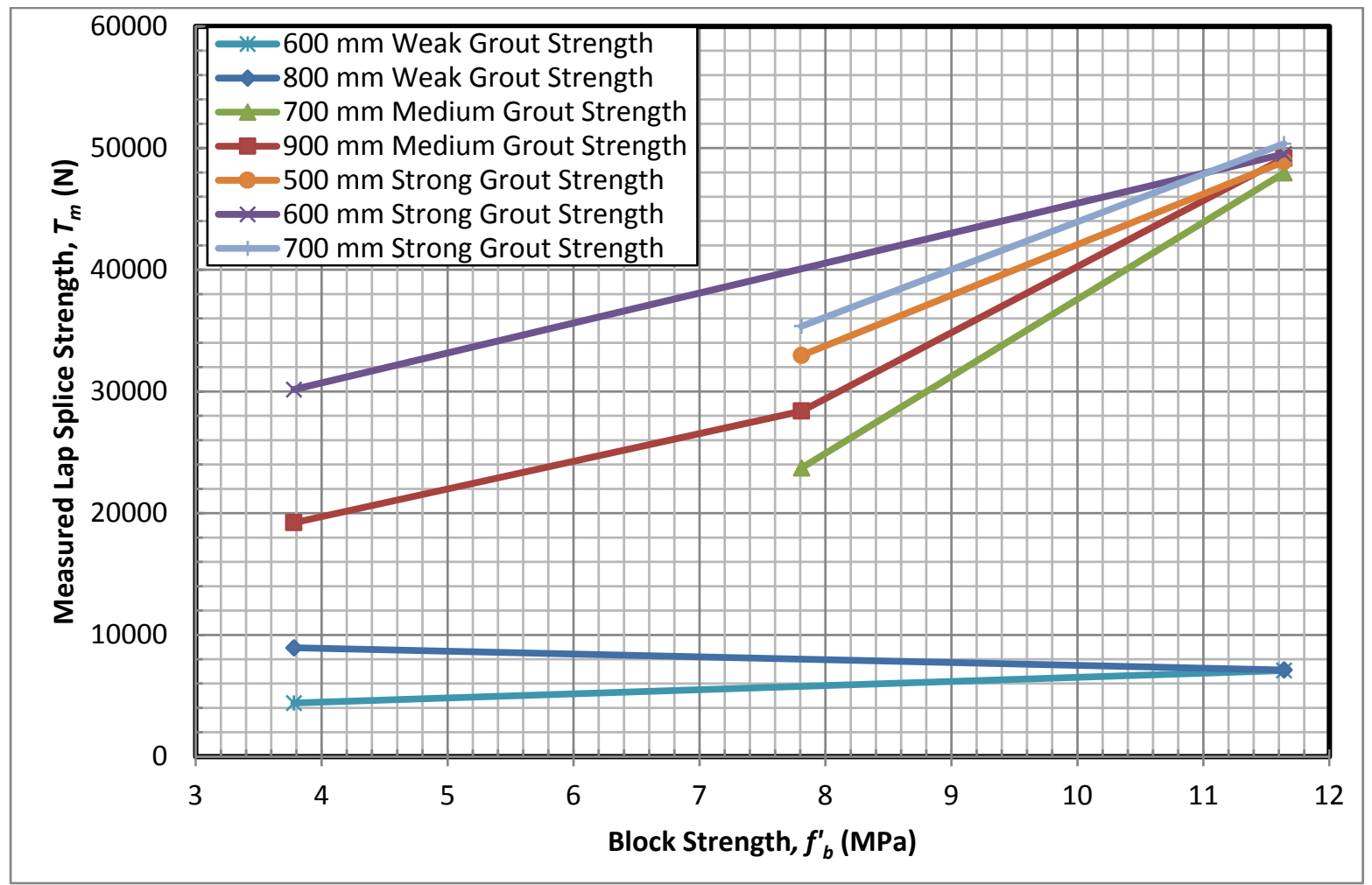

Figure 43: Measured Lap Splice Strength $\left(T_{m}\right)$ of \#4 sized bar vs. ICEB Unit Strength $\left(\boldsymbol{f}_{b}^{\prime}\right)$ 


\subsection{Measured ICEB Lap Splice Strength $\left(T_{m}\right)$ vs. Grout Strength $\left(\boldsymbol{f}_{\boldsymbol{g}}^{\prime}\right)$}

The measured lap splice strength $\left(T_{m}\right)$ of the lap splice specimen was strongly correlated to compressive strength of the grout $\left(f^{\prime}{ }_{g}\right)$. As expected, stronger grout produced stronger lap splices for all specimens of the same length regardless of ICEB unit strength or rebar size (Figure 44 and Figure 45).

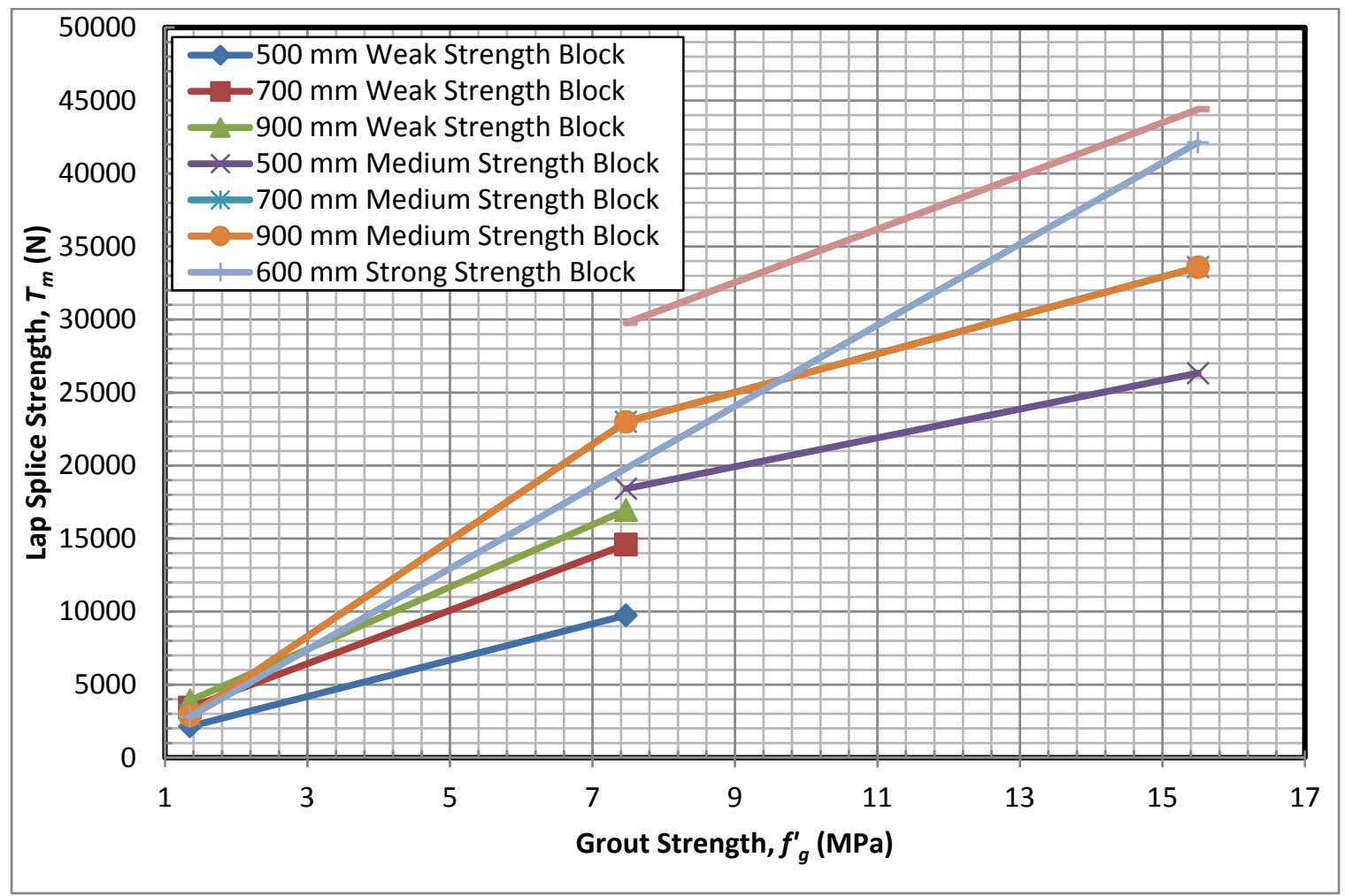

Figure 44: Measured Lap Splice Strength $\left(T_{m}\right)$ of \#3 sized bar vs. Grout $\operatorname{Strength}\left(\boldsymbol{f}_{g}^{\prime}\right)$ 


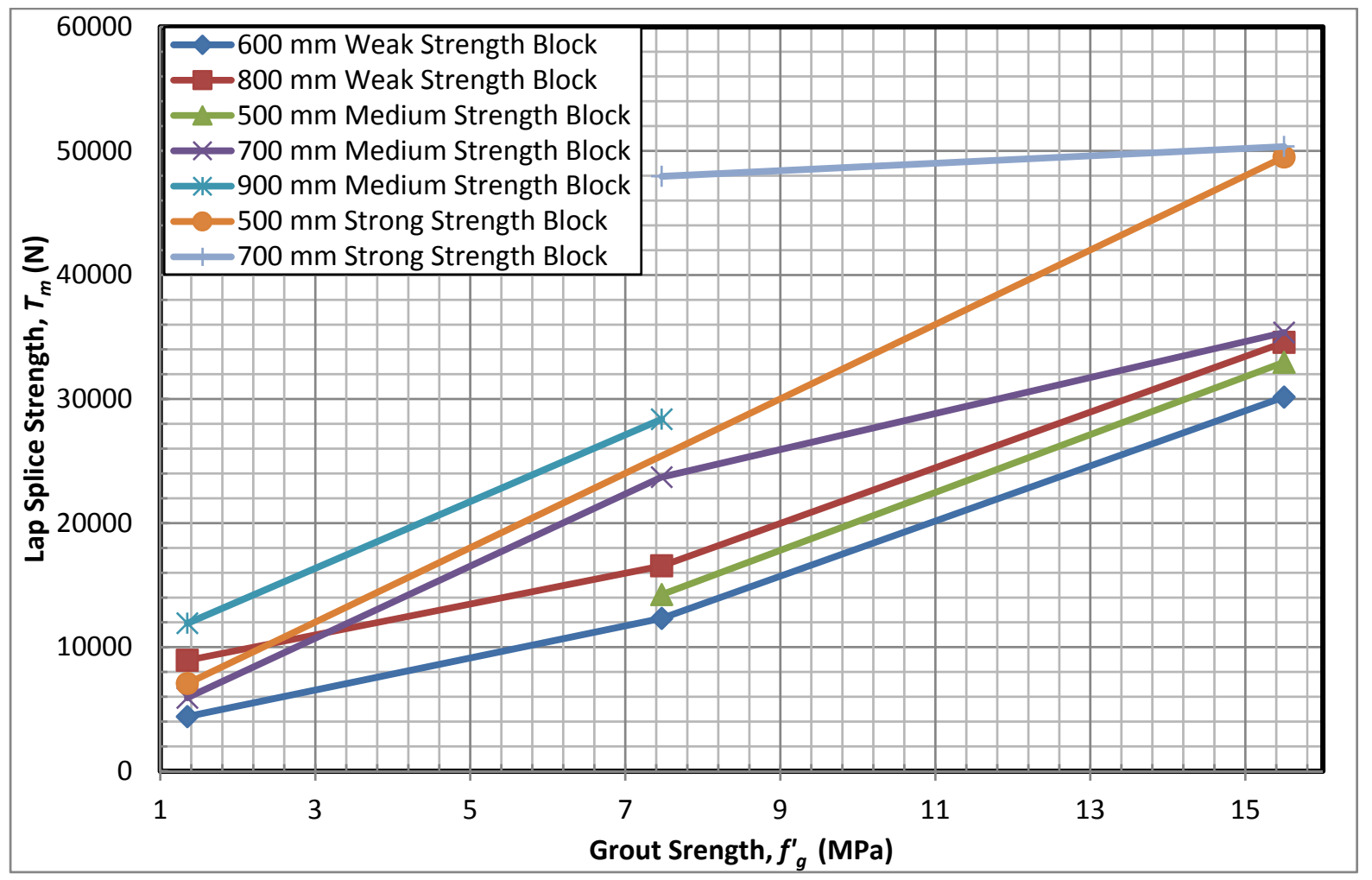

Figure 45: Measured Lap Splice Strength $\left(T_{m}\right)$ of \#4 sized bar vs. Grout Strength $\left(\boldsymbol{f}_{g}^{\prime}\right)$ 


\subsection{Measured ICEB Lap Splice Length $\left(l_{s}\right)$ vs. Measured Lap Splice Strength $\left(T_{r}\right)$}

As expected, longer rebar lap splices largely correlated with stronger lap splice specimens for all grout and ICEB unit types (See Figure 56, Figure 57, and Figure 58 in Appendix B). For lap splice specimens that experienced yielding, the ultimate strength of the lap splice was dictated by the yielding strength of the rebar. Longer lap splices increased the tensile capacity of the lap splice until the load was equal to the rebar yield strength.

\subsection{Measured ICEB Lap Splice Strength $\left(T_{m}\right)$ vs. Prism Compressive Strength $\left(\boldsymbol{f}_{m}^{\prime}\right)$}

For all lap splice specimens, a stronger prism compressive strength $\left(f^{\prime}{ }_{m}\right) \operatorname{did}$ not correlate with a stronger ICEB lap splice strength $\left(T_{m}\right)$. Figure 46 and Figure 47 demonstrate the poor relationship between the measured prism strength and measured ICEB lap splice strength. This is not surprising as the ICEB prism compressive strength is a poor indicator of the material strength of the grout (see Section 3.7.8). However, the strength of the grout is a critical factor when determining the overall strength of the lap splice as demonstrated earlier Section 5.3. Hence, the current MSJC lap splice prediction Equation 1.1, which calculates the required lap splice length by multiplying the square root of the prism strength $\left(f^{\prime}{ }_{m}\right)$, is not applicable to the ICEB lap splice specimens tested within this research. 


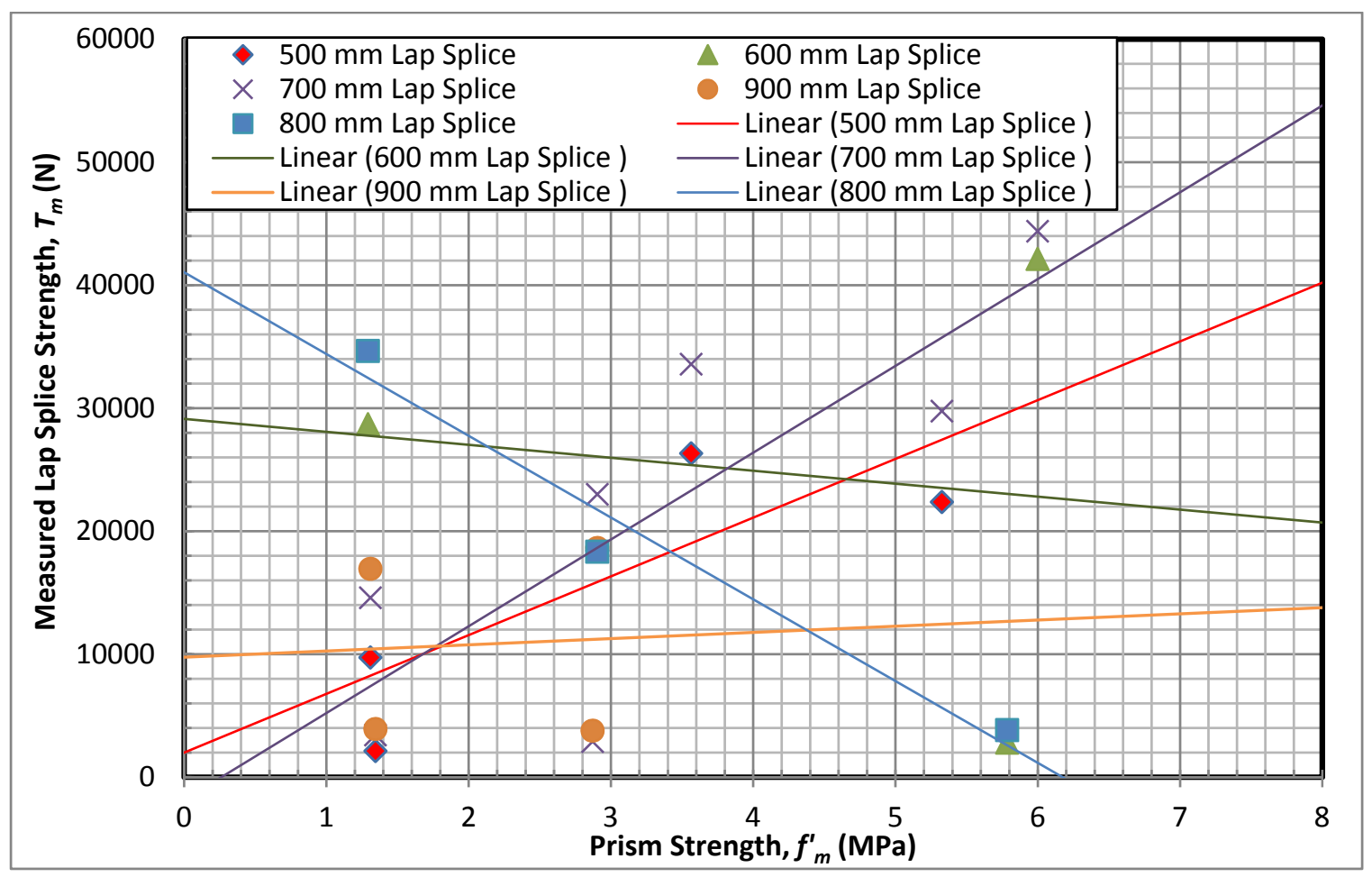

Figure 46: Measured Lap Splice Strength $\left(T_{m}\right)$ of \#3 sized bar vs. Prism Strength $\left(f^{\prime}{ }_{m}\right)$

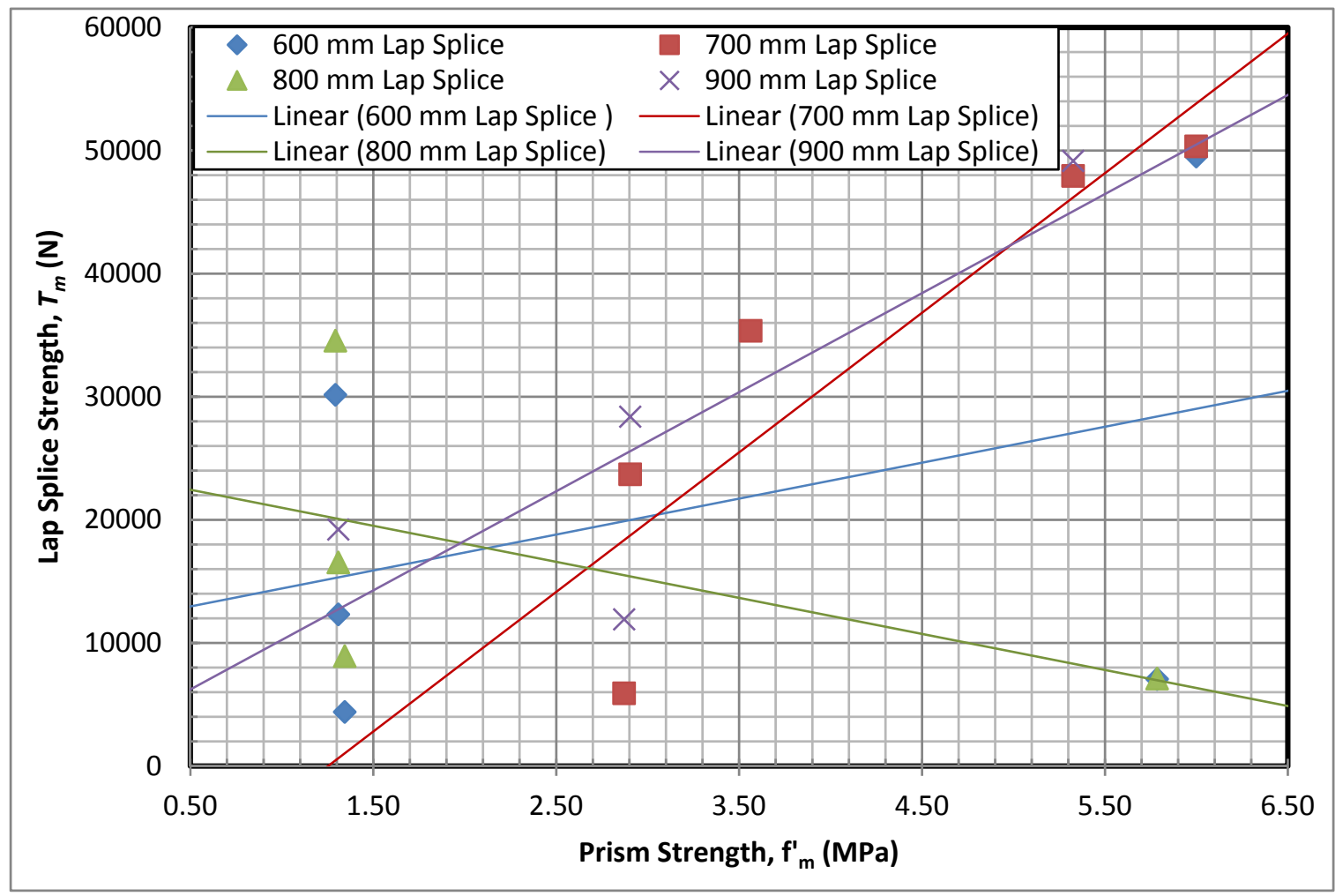

Figure 47: Measured Lap Splice Strength $\left(T_{m}\right)$ of \#4 sized bar vs. Prism Strength $\left(f^{\prime}{ }_{m}\right)$ 


\subsection{ICEB Lap Splice Equation Recommendation}

Multiple ICEB lap splice equations were developed by separating the lap splice test results into two data sets; one for size M10 (\#3) rebar and another for size M13 (\#4) rebar. A regression analysis was used to find the best form of a predictive model for each data set. As discussed in Section 5.5, ICEB prism strength $\left(f^{\prime}{ }_{m}\right)$ did not appropriately predict the lap splice strength of the specimen. However, the measured lap splice strength $\left(T_{m}\right)$ was found to be proportional to the compressive grout strength $\left(f^{\prime} g\right)$. Thus, it was necessary to add the compressive grout strength $\left(f^{\prime} g\right)$ variable to a new ICEB lap splice prediction equation. Two equations were developed that best represented the data (5.1 and 5.2). 


\subsubsection{Lap Splice Prediction Equation 5.1}

The first ICEB lap splice prediction developed, Equation 5.1, was modeled after MSJC Equation 1.1 with the addition of a grout strength factor, $\left(f^{\prime} g\right)^{A}$, and is as follows:

Where

$$
T_{r}=K \times l_{d} \sqrt{f^{\prime} m} \times\left(f^{\prime} g\right)^{A}
$$

$T_{r}=$ Predicted Lap Splice Length (N)

$K=2.07$ for M10 (\#3) sized bars, 4.79 for M13 (\#4) sized bars

$l_{d}=$ measured length of lap splice $(\mathrm{mm})$

$f^{\prime} m=$ strength of prism $(\mathrm{MPa})$

$f^{\prime} g=$ strength of grout $(\mathrm{MPa})$

$A=1.01$ for M10 (\#3) sized bars, 0.71 for M13 (\#4) sized bars

Figure 48 and Figure 49 demonstrate the relationship between the measured and modeled lap splice strengths calculated in Equation 5.1. As discussed in Section 5.1, ICEB lap splice specimens that failed due to rebar yielding were not included in the regression analysis to form Equation 5.1. These data points are included in Figure 48 and Figure 49 purely for reference. 


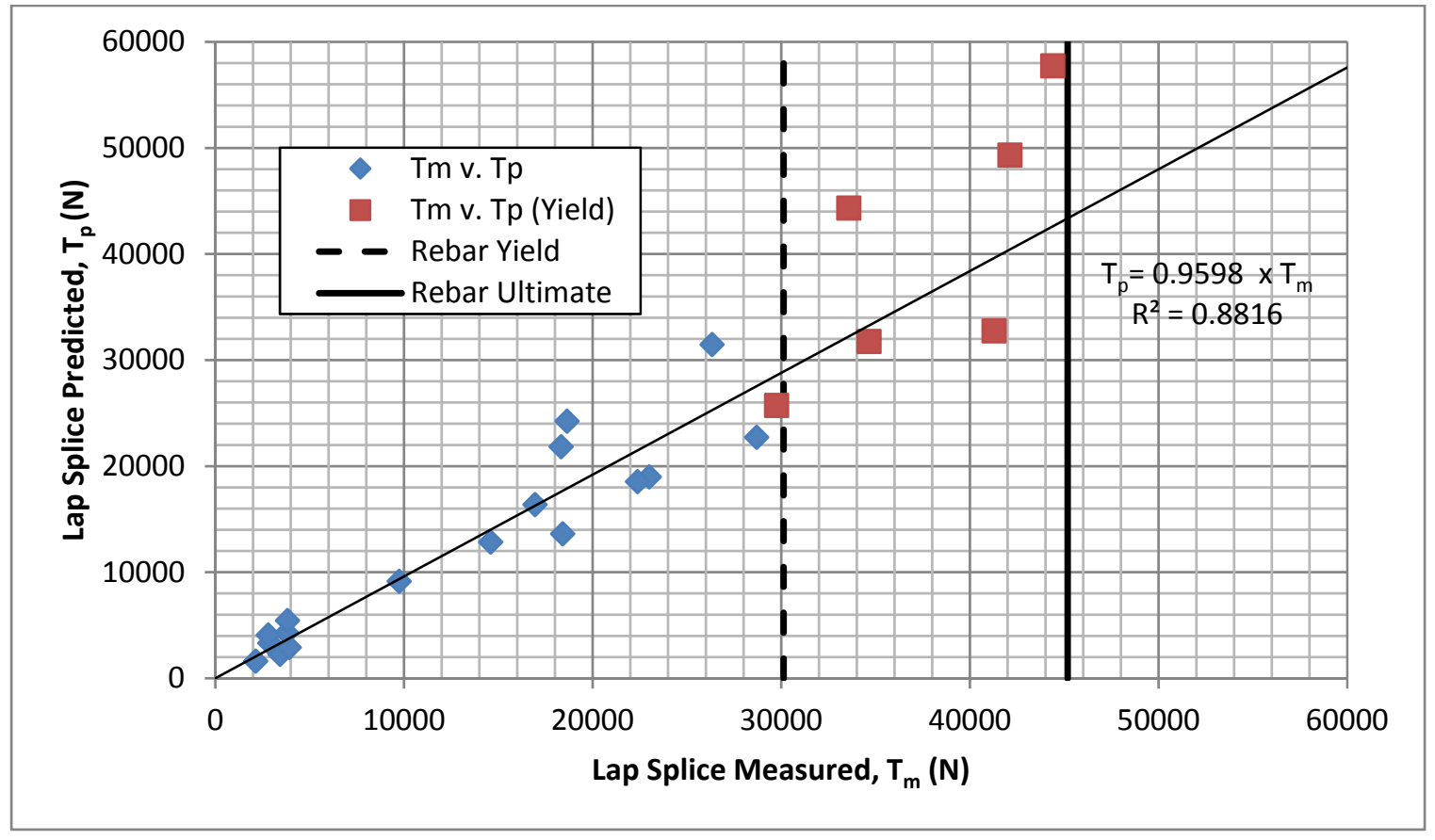

Figure 48: Relationship between Measured and Predicted Lap Splice Capacities for \#3 Sized Bar (Equation 5.1)

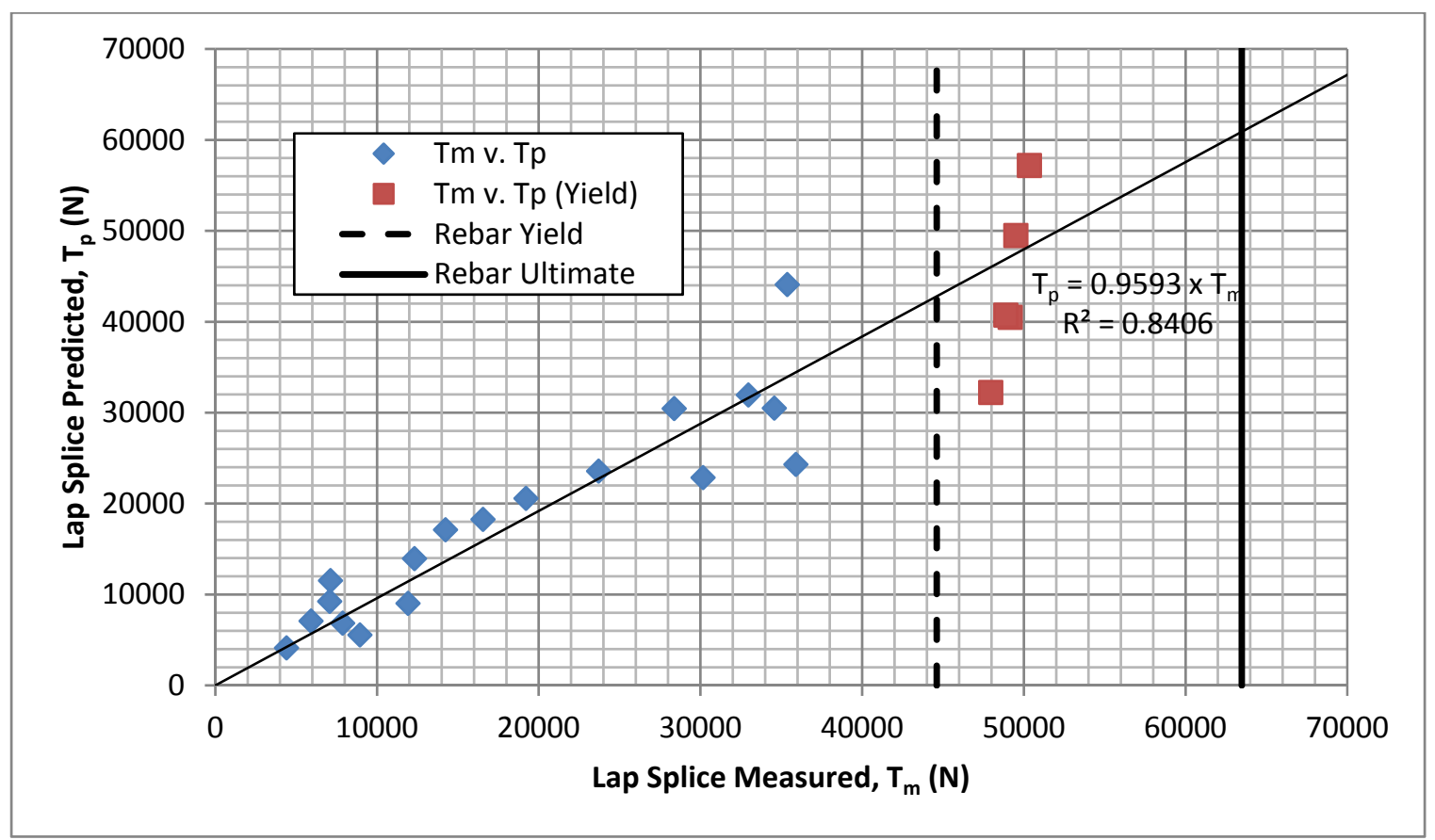

Figure 49: Relationship between Measured and Predicted Lap Splice Capacities for \#4 Sized Bar (Equation 5.1) 


\subsubsection{Lap Splice Prediction Equation 5.2}

A second lap splice prediction, Equation 5.2, was also modeled after MSJC Equation 1.1 with the addition of a grout factor, $\left(f^{\prime} g^{A}+C\right)$, and is as follows:

$$
T_{r}=K l_{d} \sqrt{f^{\prime} m} \times\left(f^{\prime} g^{A}+C\right)(5.2)
$$

Where $T_{r}=$ Predicted Lap Splice Length (N)

$K=2.70$ for M10 (\#3) sized bars, 7.34 for M13 (\#4) sized bars

$l_{d}=$ measured length of lap splice $(\mathrm{mm})$

$f^{\prime} m=$ strength of prism $(\mathrm{MPa})$

$f^{\prime} g=$ strength of grout $(\mathrm{MPa})$

$\mathrm{C}=-0.40$ for M10 (\#3) sized bars, -0.43 for M13 (\#4) sized bars

$A=0.92$ for M10 (\#3) sized bars, 0.58 for M13 (\#4) sized bars

Figure 50 and Figure 51 demonstrate the relationship between the measured and modeled lap splice strengths calculated in Equation 5.2. Similar to Equation 5.1, ICEB lap splice specimens that failed due to rebar yielding were not included in the regression analysis to form Equation 5.2. These data points are included in Figure 50 and Figure 51 purely for reference. 


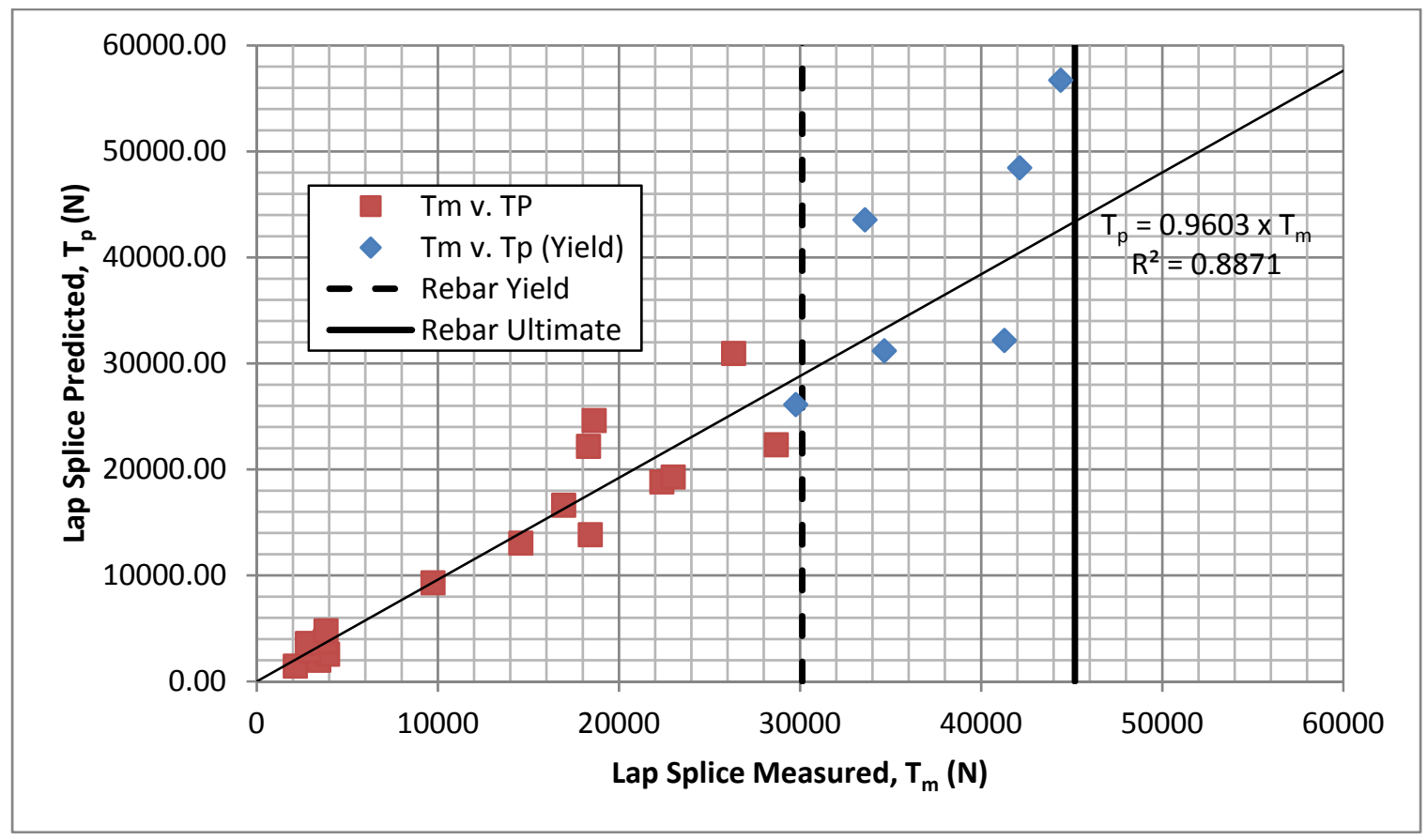

Figure 50: Relationship between Measured and Predicted Lap Splice Capacities for \#3 Sized Bar (Equation 5.2)

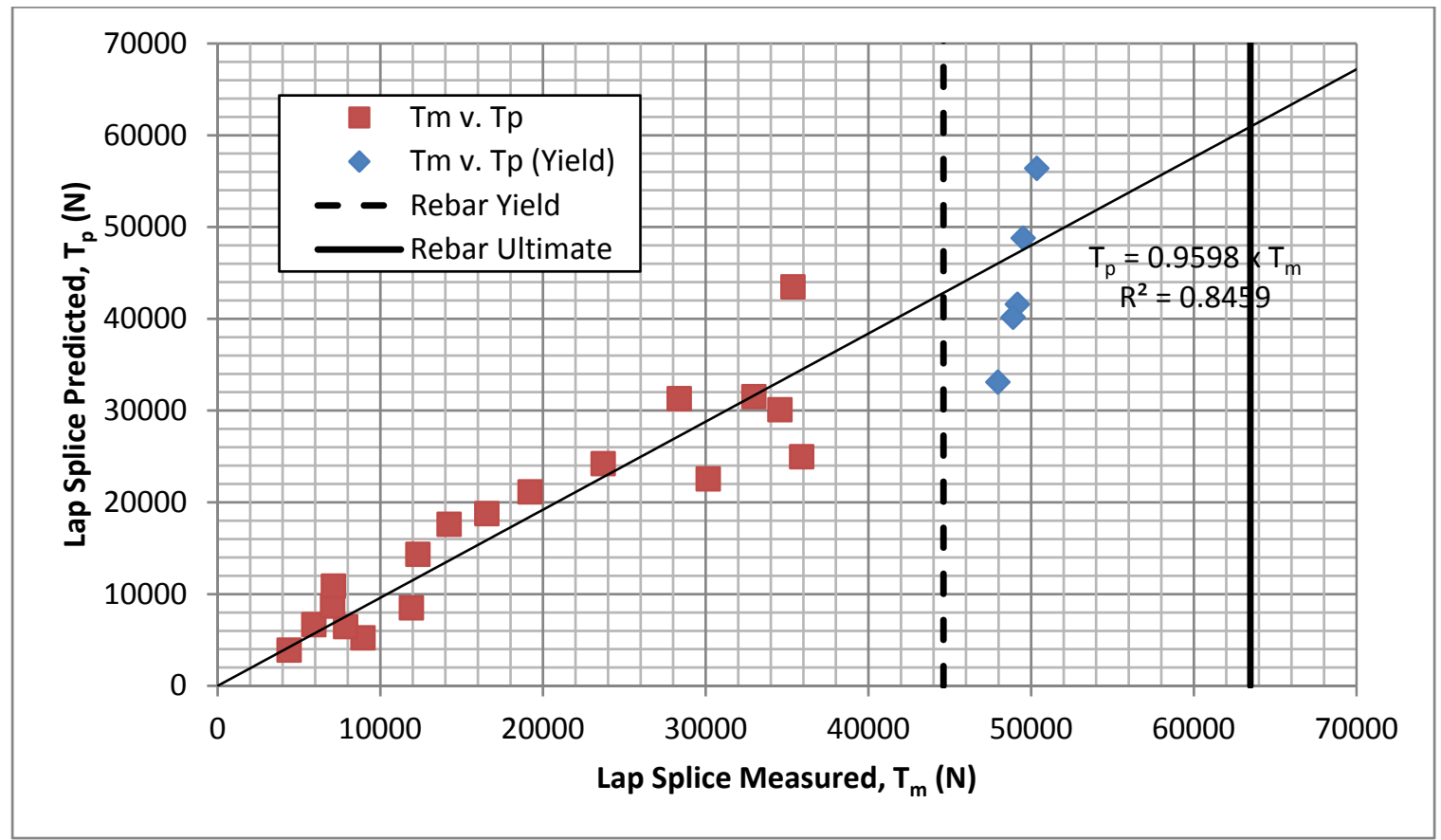

Figure 51: Relationship between Measured and Predicted Lap Splice Capacities for \#4 Sized Bar (Equation 5.2) 


\subsubsection{Lap Splice Strength Predication Equation Summary}

Equation 5.2 represented the lap splice data marginally better than Equation 5.1, however, when framed within a mathematically reality, Equation 5.2 produced negative lap splice strength prediction results for grouts of low compressive strength. Equation 5.1 was chosen as the best predictive model of lap splice strength as it predicted an accurate splice model and was more realistic.

\subsection{ICEB Lap Splice Length Prediction Equation}

Generally, shorter lap splice specimens were observed to fail violently when tested beyond the tensile capacity of the rebar lap splice. Lap spice specimens that did not have adequate rebar lap splice length to produce rebar yielding failed quickly and did not maintain any tensile strength after the specimen had failed. The typical violent failure mode of a shorter lap splice (where the rebar did not reach yield capacity) is not a desired failure limit state for lap splices. Longer lap splices that were observed to yield tended to fail by a gradual bar pullout that maintained some tensile strength even during failure. This is a more desirable failure method. To ensure that the failure mode of the lap splice specimen is gradual and non-violent, a rebar lap splice must be long enough so that the specimen fails due to the yielding of the rebar. 
Like MSJC Section 3.3.3.4, replacing the predicted strength, $T_{r}$, with $1.25 A_{b} f_{y}$ (or $125 \%$ of rebar yield strength) ensures that the lap splice specimen will fail by rebar yielding, the preferred failure limit state. By setting $T_{r}=1.25 A_{b} f_{y}$ and solving for the required length, $l_{p}$, the required lap splice length equation 5.3 was generated:

$$
l_{p}=\frac{K \times A_{b} \times f_{y}}{\sqrt{f_{m}^{\prime}} \times\left(f_{g}^{\prime}\right)^{A}}
$$

Where

$l_{p}=$ Required lap splice length $(\mathrm{mm})$

$A_{b}=$ Area of rebar $\left(\mathrm{mm}^{2}\right)$

$K=0.60$ for M10 (\#3) sized bars and 0.26 for M13 (\#4) sized bars

$f_{y}=$ Yield stress of rebar $\left(\mathrm{N} / \mathrm{mm}^{2}\right)$

$f^{\prime} m=$ Masonry prism strength (MPa)

$f^{\prime} g=$ Grout compressive strength (MPa)

And

A= 1.01 for M10 (\#3) sized bars, 0.71 for M13 (\#4) sized bars

The additional grout strength factor, $f^{\prime} g$, into the lap splice length Equation 5.3 creates an accurate model that can predict required lap splice length for both size M10 (Figure 52) and M13 (Figure 53) rebar in ICEB specimens. The highlighted yellow portion of the graph represents the range of prism strengths $\left(f^{\prime} m\right)$ tested in this research. 


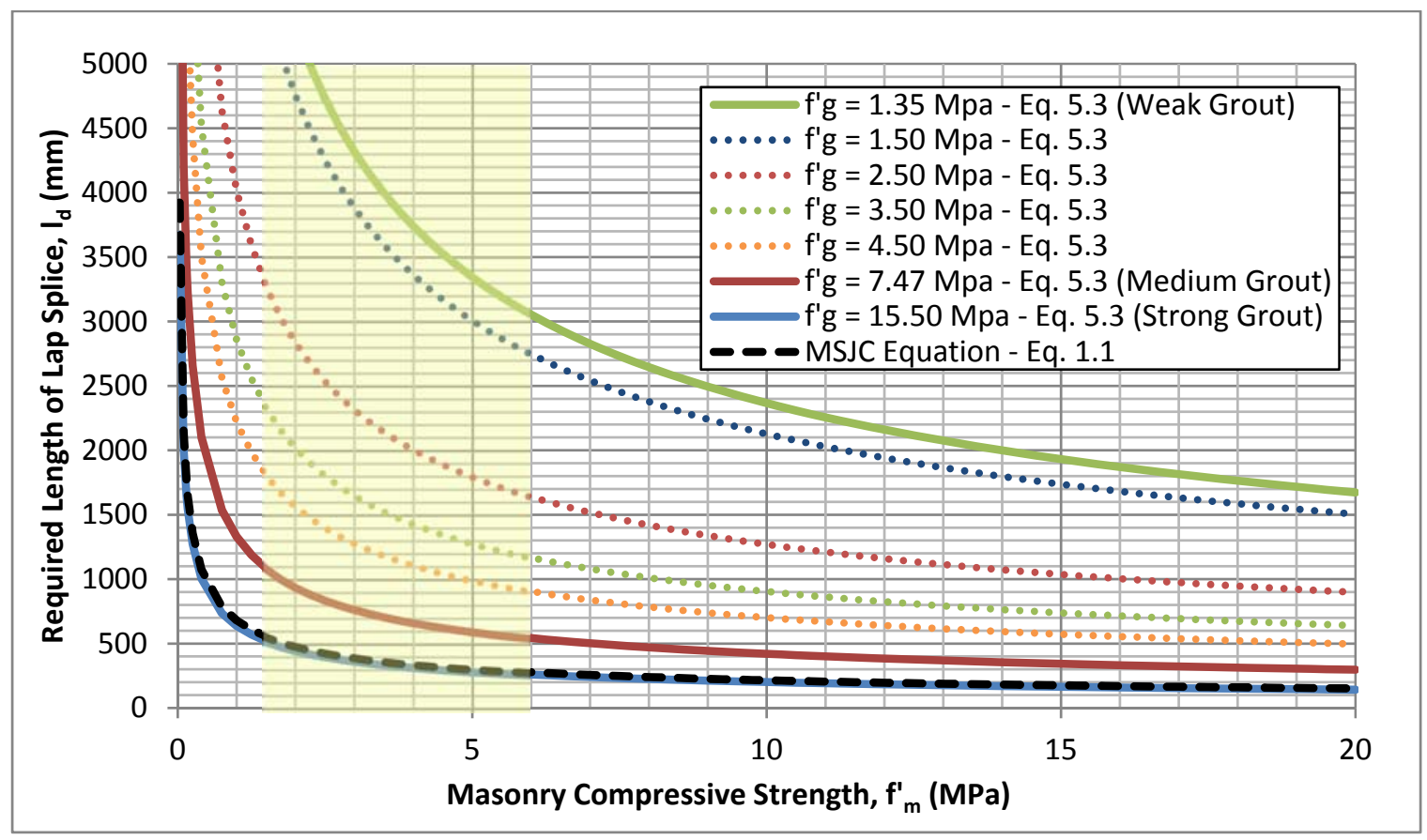

Figure 52: Require Lap Splice Length vs. Masonry Compressive Strength for M10 (\#3) Bars

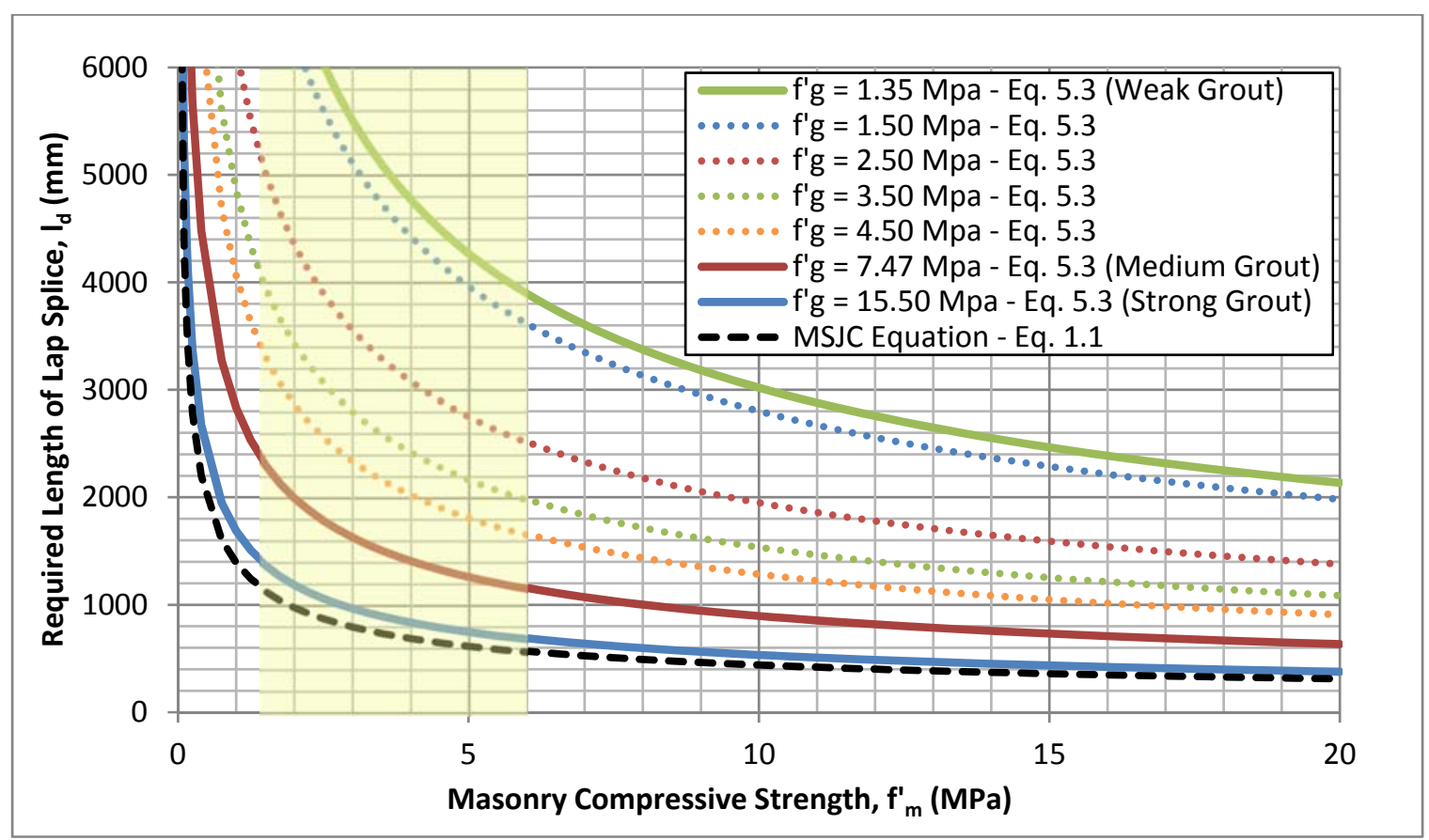

Figure 53: Require Lap Splice Length vs. Masonry Compressive Strength for M13 (\#4) Bars 
Additionally, substituting in prism prediction Equation 3.2 into Equation 5.3 for $f^{\prime} m$ we arrive at:

$$
l_{p}=\frac{K \times A_{b} \times f_{y}}{\left(f_{b}^{\prime}\right)^{0.66} \times\left(f_{g}^{\prime}\right)^{A}}
$$

$l_{p}=$ Required lap splice length $(\mathrm{mm})$

$A_{b}=$ Area of rebar $\left(\mathrm{mm}^{2}\right)$

$K=1.28$ for M10 (\#3) sized bars and 0.55 for M13 (\#4) sized bars

$f_{y}=$ Yield stress of rebar $\left(\mathrm{N} / \mathrm{mm}^{2}\right)$

$f^{\prime} b=$ ICEB unit strength (MPa)

$f^{\prime} g=$ Grout compressive strength (MPa)

And

$A=1.01$ for M10(\#3) sized bars, 0.71 for M13(\#4) sized bars

By substituting the ICEB unit strength $\left(f^{\prime} b\right)$ for the prism strength in Equation 5.4 we can calculate the required lap splice length for both size M10 (Figure 54) and M13 (Figure 55) bars without measuring the prism strength $\left(f^{\prime} m\right)$. The highlighted yellow portion of the graph represents the range of block strengths $\left(f^{\prime} b\right)$ tested in this research. 


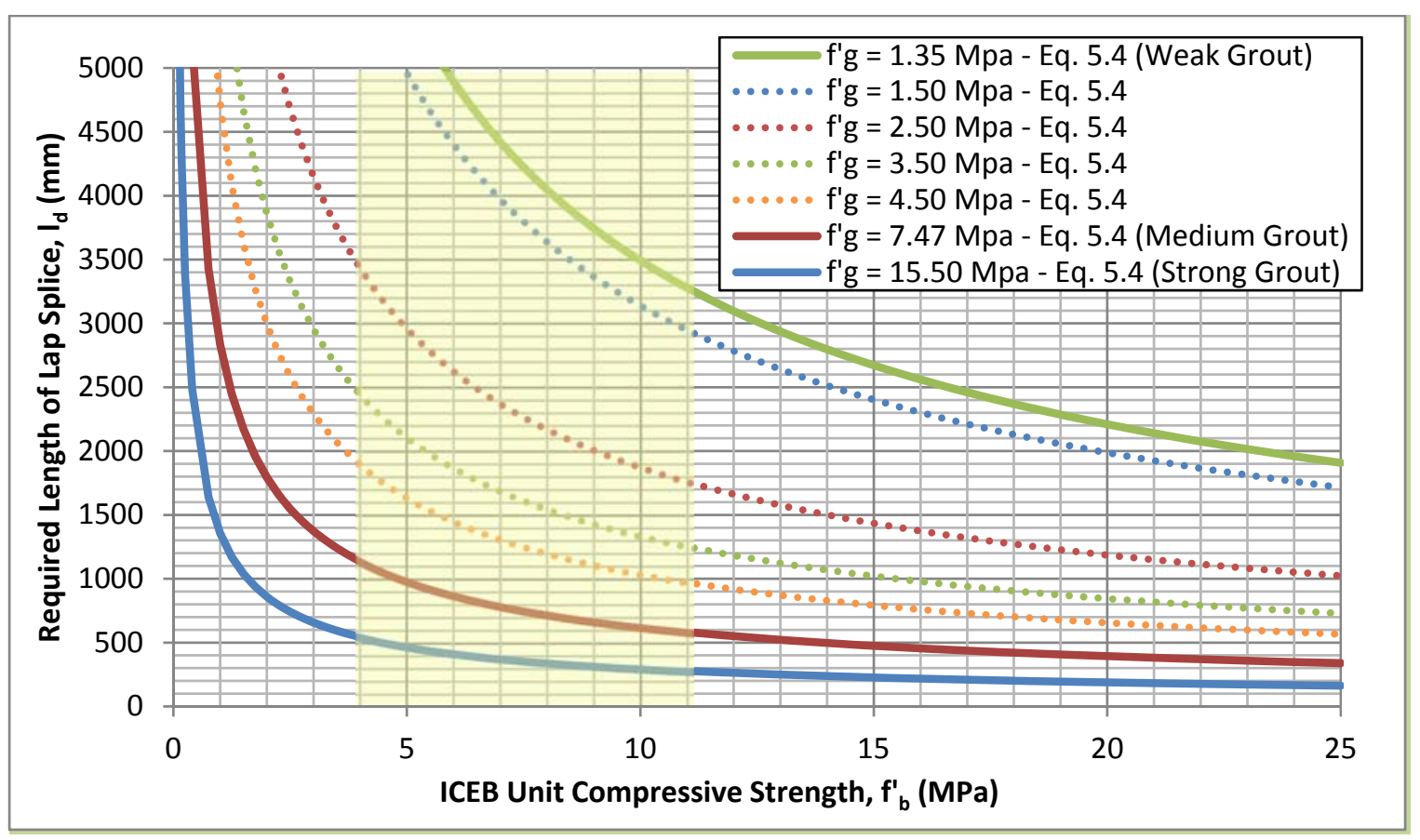

Figure 54: Require Lap Splice Length vs. ICEB Unit Compressive Strength for M10 (\#3), Grade 40 Bars

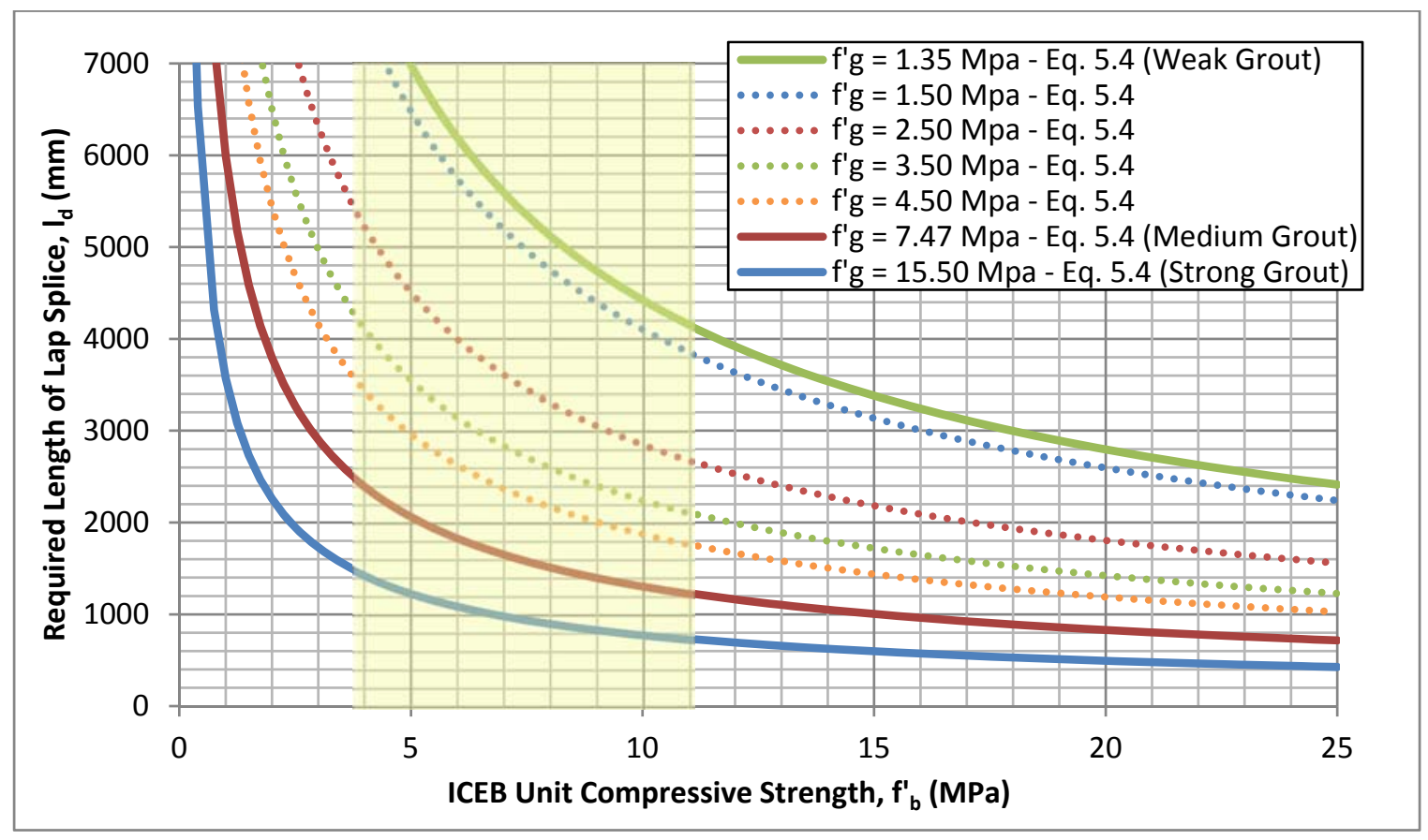

Figure 55: Require Lap Splice Length vs. ICEB Unit Compressive Strength for M13 (\#4), Grade 60 Bars 
As displayed in Figure 55 through Figure 58 above, the weak grout used in this research $\left(f_{g}^{;}=1.39 \mathrm{MPa}\right)$ was not strong enough for the rebar in any lap splice specimen to reach yield. It is recommended that the grout strength within ICEB structures be sufficient to reach $125 \%$ of bar yield. Thus, the weak grout tested in this research is impractical in design applications due to the long length of the rebar lap splice that would be required. Furthermore, Table 33 and Table 34 provide the required lap splice length for the materials tested in this research to reach $125 \%$ of the yield capacity of the rebar as calculated from Equation 5.4.

Table 33: Required Length for M10 (\#3) Bar to Reach 125\% Yield of Rebar (Grade 40)

\begin{tabular}{|c|c|c|c|c|c|}
\hline & & & Aver & e Grout St & ength \\
\hline & & & $\begin{array}{l}\text { Weak } \\
\text { Grout }\end{array}$ & $\begin{array}{c}\text { Medium } \\
\text { Grout }\end{array}$ & $\begin{array}{l}\text { Strong } \\
\text { Grout }\end{array}$ \\
\hline & & & $\begin{array}{l}1.35 \mathrm{MPa} \\
\text { (195 psi) }\end{array}$ & $\begin{array}{l}7.47 \mathrm{MPa} \\
\text { (1084 psi) }\end{array}$ & $\begin{array}{l}15.50 \mathrm{MPa} \\
(2248 \mathrm{psi})\end{array}$ \\
\hline & $\begin{array}{c}\text { Weak ICEB } \\
\text { Unit }\end{array}$ & $\begin{array}{l}3.78 \mathrm{MPa} \\
\text { (548 psi) }\end{array}$ & $\begin{array}{l}6636 \mathrm{~mm} \\
(21.8 \mathrm{ft} .)\end{array}$ & $\begin{array}{c}1179 \mathrm{~mm} \\
(3.9 \mathrm{ft} .)\end{array}$ & $\begin{array}{l}564 \mathrm{~mm} \\
(1.9 \mathrm{ft} .)\end{array}$ \\
\hline $\begin{array}{c}\text { Average ICEB } \\
\text { Unit Strength }\end{array}$ & $\begin{array}{l}\text { Medium } \\
\text { ICEB Unit }\end{array}$ & $\begin{array}{l}7.81 \mathrm{MPa} \\
\text { (1133 psi) }\end{array}$ & $\begin{array}{l}4110 \mathrm{~mm} \\
(13.5 \mathrm{ft} .)\end{array}$ & $\begin{array}{l}730 \mathrm{~mm} \\
(2.4 \mathrm{ft} .)\end{array}$ & $\begin{array}{l}349 \mathrm{~mm} \\
(1.1 \mathrm{ft} .)\end{array}$ \\
\hline & $\begin{array}{c}\text { Strong } \\
\text { ICEB Unit }\end{array}$ & $\begin{array}{c}11.38 \mathrm{MPa} \\
(1650 \mathrm{psi})\end{array}$ & $\begin{array}{l}3206 \mathrm{~mm} \\
(10.5 \mathrm{ft} .)\end{array}$ & $\begin{array}{c}570 \mathrm{~mm} \\
\text { (1.9 ft.) }\end{array}$ & $\begin{array}{c}273 \text { mm } \\
\text { (0.9 ft.) }\end{array}$ \\
\hline
\end{tabular}

Table 34: Required Length for M13 (\#4) Bar to Reach 125\% Yield of Rebar (Grade 60)

\begin{tabular}{|c|c|c|c|c|c|}
\hline & & & \multicolumn{3}{|c|}{ Average Grout Strength } \\
\hline & & & $\begin{array}{l}\text { Weak } \\
\text { Grout }\end{array}$ & $\begin{array}{c}\text { Medium } \\
\text { Grout }\end{array}$ & $\begin{array}{r}\text { Strong } \\
\text { Grout }\end{array}$ \\
\hline & & & $\begin{array}{l}1.35 \mathrm{MPa} \\
(195 \mathrm{psi})\end{array}$ & $\begin{array}{l}7.47 \mathrm{MPa} \\
(1084 \mathrm{psi}) \\
\end{array}$ & $\begin{array}{c}15.50 \mathrm{MPa} \\
\text { (2248 psi) }\end{array}$ \\
\hline \multirow{3}{*}{$\begin{array}{l}\text { Average ICEB } \\
\text { Unit Strength }\end{array}$} & $\begin{array}{c}\text { Weak ICEB } \\
\text { Unit }\end{array}$ & $\begin{array}{c}3.78 \mathrm{MPa} \\
(548 \mathrm{psi})\end{array}$ & $\begin{array}{c}8396 \text { mm } \\
(27.5 \text { ft. })\end{array}$ & $\begin{array}{c}2492 \mathrm{~mm} \\
\text { (8.2 ft.) }\end{array}$ & $\begin{array}{c}1484 \mathrm{~mm} \\
(4.9 \mathrm{ft} .)\end{array}$ \\
\hline & $\begin{array}{l}\text { Medium } \\
\text { ICEB Unit }\end{array}$ & $\begin{array}{l}7.81 \mathrm{MPa} \\
(1133 \mathrm{psi}) \\
\end{array}$ & $\begin{array}{c}5201 \mathrm{~mm} \\
(17.1 \mathrm{ft} .)\end{array}$ & $\begin{array}{c}1544 \mathrm{~mm} \\
\text { (5.1 ft.) }\end{array}$ & $\begin{array}{r}919 \mathrm{~mm} \\
(3.0 \mathrm{ft} .) \\
\end{array}$ \\
\hline & $\begin{array}{l}\text { Strong } \\
\text { ICEB Unit }\end{array}$ & $\begin{array}{l}11.38 \mathrm{MPa} \\
(1650 \mathrm{psi})\end{array}$ & $\begin{array}{c}4056 \mathrm{~mm} \\
(13.3 \mathrm{ft} .)\end{array}$ & $\begin{array}{c}1204 \mathrm{~mm} \\
(4.0 \mathrm{ft} .)\end{array}$ & $\begin{array}{c}717 \mathrm{~mm} \\
(2.4 \mathrm{ft} .)\end{array}$ \\
\hline
\end{tabular}




\section{CONCLUSIONS AND RECOMMENDATIONS}

The research findings are summarized by the following:

- The compressive grout strength is affected by the water absorption capacity of the ICEB unit. When grout is cast within ICEB units, the high absorption rate of the ICEB can dramatically affect the strength of the grout. The compressive strength of grout specimens cured in ICEB units were considerably greater than the compressive strength of grout specimens cured in non-porous plastic cylinders.

- The prism compressive strength was directly correlated to the strength of the ICEB unit. There was no correlation between the compressive strength of the grout and the prism strength, if the prism was fully grouted. A prism compressive strength prediction equation was proposed for both fully grouted and non-grouted ICEB prisms.

- $\quad$ The MSJC does not appropriately predict the tensile strength of weaker ICEB lap splice specimens. The prism compressive strength, the key factor in calculating lap splice strength in the MSJC equation, does not accurately predict the lap splice strength of the specimens tested in this research. A new prediction equation is proposed for lap splices constructed from fully grouted ICEB units.

- ICEB lap splice findings were commensurate with findings found in previous lap splice research for concrete and concrete masonry units and are summarized below. 
o Stronger ICEB units produced stronger lap splices and increased resistance to longitudinal tensile splitting.

o Stronger grout strength increased the strength of the lap splice.

o Increasing lap splice length increased the lap splice strength when bar pullout governed the splice strength 


\subsection{Potential for Future Work}

It is recommended more research continue to be completed in the realm of interlocking compressed earth blocks, specifically those pressed from the BP6 Press, as no definitive engineering or construction guidelines exist.

The strength of the ICEB prism was found to be determined by the strength of the ICEB unit and not the strength of the grout, if the prism was fully grouted. More research should be completed to understand the mechanics of this finding.

More research can be completed in developing economical mix proportions for ICEB units and grout. Cement can be an expensive material in many areas of the world, so developing strong ICEB structures that use cost efficient materials is prudent.

It is unknown if a larger ICEB grouting hole would have produced lap splice results that more closely matched the lap splice strength as predicted by the MSJC equation. More research should be completed to determine the effects of clear cover reduction in ICEB lap splices.

This research was completed by using ICEB half blocks with one side grouting channel. Failure of the ICEB lap splice often resulted with a longitudinal crack along the grout channel/block interface. Based on this observation, it is expected that blocks without a side grouting channel may produce stronger lap splices. Conversely, blocks with two side 
grouting channels may produce weaker lap splices. More lap splice research should be completed to confirm this hypothesis. 


\section{WORKS CITED}

Bland, D. W. (2011). In-Plane Cyclic Shear Performance of Interlocking Compressed Earth Block Shear Walls. Master's Theses and Project Reports, 2011, 1-144.Retrieved August 10, 2011, from the Cal Poly Digital Commons database.

Building code requirements and specification for masonry structures: containing Building code requirements for masonry structures (TMS 402-08/ACI530-08/ASCE 5-08), Specification for masonry structures (TMS 602-08/ACI 530.1-08/ASCE 6-08) and companion com. Boulder, Colo.: Masonry Society, 2008.

Contreras, F. (2007) Adobe Conservation: A Preservation Handbook. Sunstone Press. ISBN 978-81-8986621-1. Retrieved 2014-04-07.

Darwin, D., McCabe, S., Idun, E., Schoenekase, S. (1992). Development Length Criteria: Bars Without Transverse Reinforcement. The Civil Engineering Research Foundation.

Dayton Bar Lock ${ }^{\circledR}$ Coupler. (2011). Dayton Online Catalog.

Deboucha, S. and Hasim, R. (2010). A review on bricks and stabilized compressed earth blocks. Scientific Research and Essays. Vol. 6(3), pp. 499-506

Hammons, M.I., Atkinson, R.H., Schuller, M.P., Tikalsky, P.J. (1994). Masonry Research for Limit-States Design. Construction Productivity Advancement Research Program Technical Report. CPAR-SL94-1.

Herskedal, N. A. (2012). Investigation of Out-of-Plane Properties of Interlocking Compressed Earth Block Walls. Master's Theses and Project Reports, 1-142. Retrieved February 12, 2013, from the Cal Poly Digital Commons database.

Jagadish, K.S. (2007). Building with Stabilized Mud. I.K. International Pvt Ltd. ISBN 798-81-89866-21-1. Retrieved 2014-04-07.

Pacheco-Torgal, F., and Said, J. (2012). Earth construction: Lessons from the past for future eco-efficient construction. Construction and building materials: 512-519.

Ronald, R. (2009). Earth architecture. Princeton Architectural Press.

Sattar, S., \& Liel, A. B. (2010). Seismic performance of reinforced concrete frame structures with and without masonry infill walls. In 9th US National and 10th Canadian Conference on Earthquake Engineering.

Stirling, B. J. (2011). Flexural Behavior of Interlocking Compressed Earth Block Walls Subjected to InPlane Loading. Master's Theses and Project Reports, 2011, 1-199. Retrieved August 14, 2011, from the Cal Poly Digital Commons database.

Walker, P., \& Stace, T. (1997). Properties of some cement stabilized compressed earth blocks and mortars. Materials and Structures, 30, 545-551.

Wheeler, G. (2005). Interlocking Compressed Earth Blocks Volume II. Manual of Construction. Eschborn: German Appropriate Technology Exchange-GATE. 


\section{APPENDICES}

\section{APPENDIX A: NOTATION SUMMARY}

$$
\begin{aligned}
& A_{n b}=\text { ICEB unit net area } \\
& A_{g b}=\text { ICEB unit gross area } \\
& d_{b}=\text { Diameter of rebar } \\
& d_{b l}=\text { ICEB unit reinforcement hole diameter } \\
& f^{\prime} b=\text { Average strength of un-grouted ICEB unit } \\
& f^{\prime} b s=\text { Strength of un-grouted single ICEB unit } \\
& f^{\prime} g=\text { Strength of grout } \\
& f^{\prime} m=\text { Measured strength of Prism } \\
& f^{\prime} n g=\text { Strength of non porous grout } \\
& f^{\prime} p m=\text { Predicted strength of prism } \\
& f^{\prime} u m=\text { Measured strength of un-grouted prism } \\
& f_{u}=\text { Ultimate tensile strength of rebar } \\
& f_{y}=\text { Yield tensile strength of rebar } \\
& \text { Hp = Humidity at pressing } \\
& h_{b}=\text { ICEB unit height } \\
& l_{b}=\text { ICEB unit length (half block) } \\
& l_{d}=\text { Measured length of lap splice } \\
& l_{g}=\text { ICEB unit side channel length } \\
& l_{p}=\text { Predicted length of lap splice } \\
& w_{g}=\text { ICEB unit side channel width } \\
& T r=\text { Temperature at pressing } \\
& w_{b}=\text { Measured lap splice strength } \\
& \text { TCEB unit width }
\end{aligned}
$$


APPENDIX B: LAP SPLICE SPECIMEN DATA

Table 35: MSJC Predicted Lap Splice Strength $\left(T_{r}\right)$ vs. Measured Strength $\left(T_{m}\right)$ (\#3 sized rebar)

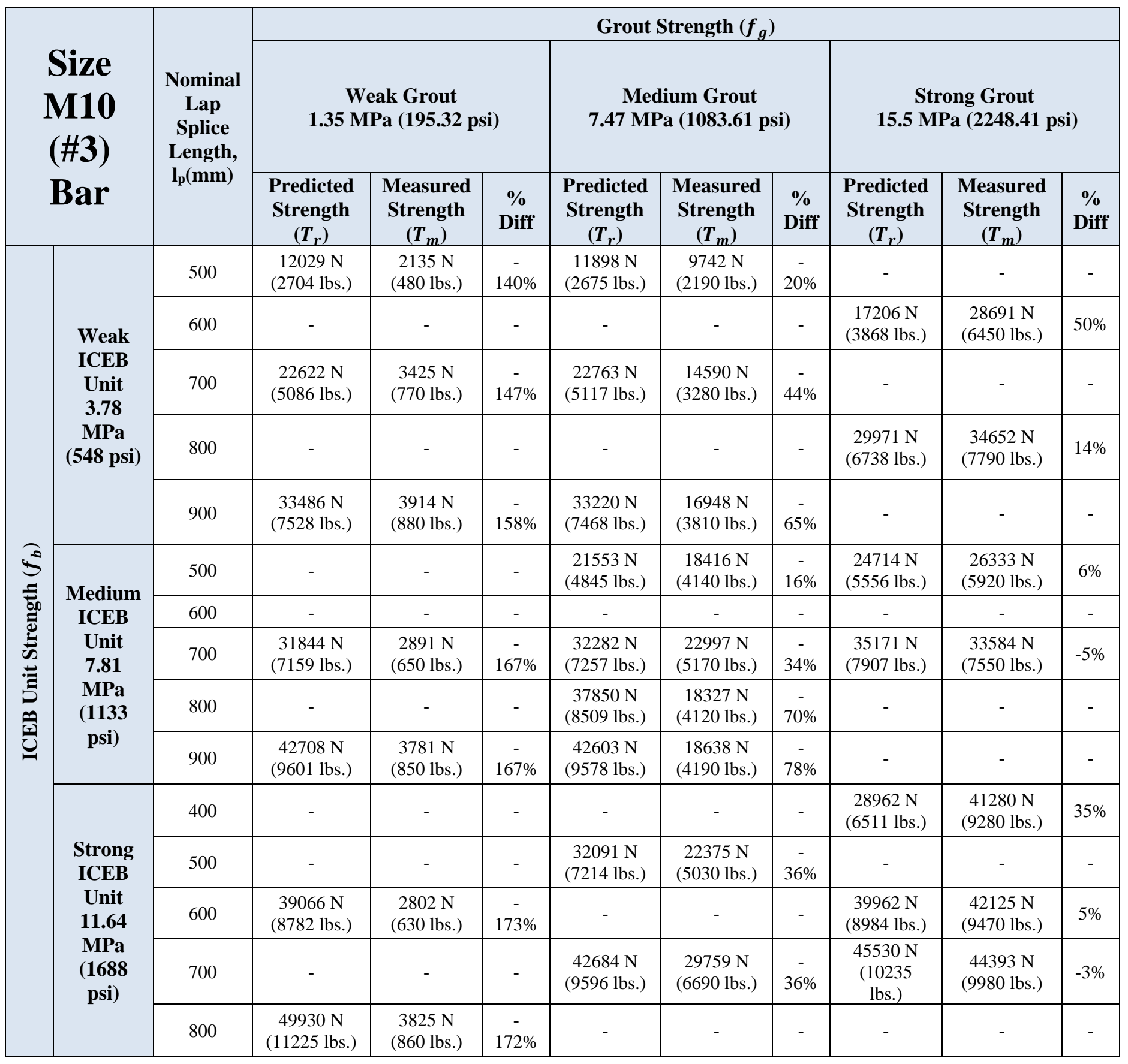


Table 36: MSJC Predicted Lap Splice Strength $\left(T_{r}\right)$ vs. Measured Strength $\left(T_{m}\right)$ (\#4 sized rebar)

\begin{tabular}{|c|c|c|c|c|c|c|c|c|c|c|c|}
\hline \multirow{3}{*}{\multicolumn{2}{|c|}{$\begin{array}{c}\text { Size } \\
\text { M13 } \\
\text { (\#4) } \\
\text { Bar }\end{array}$}} & \multirow{4}{*}{$\begin{array}{c}\begin{array}{c}\text { Nominal } \\
\text { Lap } \\
\text { Splice } \\
\text { Length, } \\
\mathbf{l}_{\mathbf{p}} \text { (mm) }\end{array} \\
600\end{array}$} & \multicolumn{9}{|c|}{ Grout Strength $\left(f^{\prime}{ }_{g}\right)$} \\
\hline & & & \multicolumn{3}{|c|}{$\begin{array}{c}\text { Weak Grout } \\
1.35 \text { MPa (195.32 psi) }\end{array}$} & \multicolumn{3}{|c|}{$\begin{array}{c}\text { Medium Grout } \\
\text { 7.47 MPa (1083.61 psi) }\end{array}$} & \multicolumn{3}{|c|}{$\begin{array}{c}\text { Strong Grout } \\
\text { 15.5 MPa (2248.41 psi) }\end{array}$} \\
\hline & & & $\begin{array}{l}\text { Predicted } \\
\text { Strength } \\
\left(T_{r}\right)\end{array}$ & $\begin{array}{l}\text { Measured } \\
\text { Strength } \\
\left(T_{m}\right)\end{array}$ & $\begin{array}{l}\% \\
\text { Diff }\end{array}$ & $\begin{array}{c}\text { Predicted } \\
\text { Strength } \\
\left(T_{r}\right)\end{array}$ & $\begin{array}{l}\text { Measured } \\
\text { Strength } \\
\left(T_{m}\right)\end{array}$ & $\begin{array}{c}\% \\
\text { Diff }\end{array}$ & $\begin{array}{l}\text { Predicted } \\
\text { Strength } \\
\left(T_{r}\right)\end{array}$ & $\begin{array}{l}\text { Measured } \\
\text { Strength } \\
\left(T_{m}\right)\end{array}$ & $\begin{array}{l}\% \\
\text { Diff }\end{array}$ \\
\hline \multirow{15}{*}{ 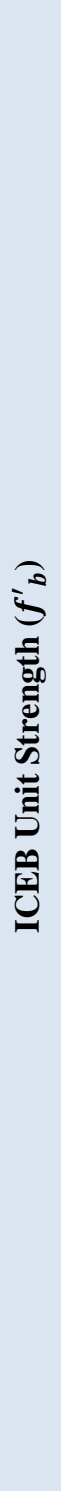 } & \multirow{5}{*}{$\begin{array}{c}\text { Weak } \\
\text { ICEB } \\
\text { Unit } \\
3.78 \\
\text { MPa } \\
\text { (548 } \\
\text { psi) }\end{array}$} & & $\begin{array}{l}39122 \mathrm{~N} \\
\text { (8795 lbs.) }\end{array}$ & $\begin{array}{c}4404 \mathrm{~N} \\
\text { (990 lbs.) }\end{array}$ & $-160 \%$ & $\begin{array}{c}39399 \mathrm{~N} \\
\text { (8857 lbs.) }\end{array}$ & $\begin{array}{c}12322 \mathrm{~N} \\
(2770 \text { lbs.) }\end{array}$ & $-105 \%$ & $\begin{array}{c}38731 \mathrm{~N} \\
\text { (8707 lbs.) }\end{array}$ & $\begin{array}{c}30159 \mathrm{~N} \\
\text { (6780 lbs.) }\end{array}$ & $-25 \%$ \\
\hline & & 700 & - & - & - & - & - & - & - & - & - \\
\hline & & 800 & $\begin{array}{c}50123 \mathrm{~N} \\
(11268 \\
\text { lbs.) }\end{array}$ & $\begin{array}{c}8941 \mathrm{~N} \\
(2010 \text { lbs.) }\end{array}$ & $-139 \%$ & $\begin{array}{c}49584 \mathrm{~N} \\
(11147 \\
\text { lbs.) }\end{array}$ & $\begin{array}{l}16547 \mathrm{~N} \\
(3720 \text { lbs.) }\end{array}$ & $-100 \%$ & $\begin{array}{c}49595 \mathrm{~N} \\
(11149 \text { lbs.) }\end{array}$ & $\begin{array}{c}34563 \mathrm{~N} \\
(7770 \text { lbs.) }\end{array}$ & $-36 \%$ \\
\hline & & 900 & - & - & - & $\begin{array}{c}55016 \mathrm{~N} \\
(12368 \\
\text { lbs.) }\end{array}$ & $\begin{array}{l}19216 \mathrm{~N} \\
(4320 \text { lbs.) }\end{array}$ & $-96 \%$ & - & - & - \\
\hline & & 1000 & $\begin{array}{c}60308 \mathrm{~N} \\
(13558 \\
\text { lbs.) }\end{array}$ & $\begin{array}{c}7873 \mathrm{~N} \\
(1770 \text { lbs.) }\end{array}$ & $-154 \%$ & - & - & - & - & - & - \\
\hline & \multirow{5}{*}{$\begin{array}{c}\text { Medium } \\
\text { ICEB } \\
\text { Unit } \\
7.81 \\
\text { MPa } \\
\text { (1133 } \\
\text { psi) }\end{array}$} & 500 & - & - & - & $\begin{array}{c}43214 \mathrm{~N} \\
\text { (9715 lbs.) }\end{array}$ & $\begin{array}{c}14234 \mathrm{~N} \\
(3200 \mathrm{lbs} .)\end{array}$ & $-101 \%$ & $\begin{array}{c}46511 \mathrm{~N} \\
(10456 \text { lbs.) }\end{array}$ & $\begin{array}{l}32961 \mathrm{~N} \\
\text { (7410 lbs.) }\end{array}$ & $-34 \%$ \\
\hline & & 600 & - & - & - & - & - & - & - & - & - \\
\hline & & 700 & $\begin{array}{c}53776 \mathrm{~N} \\
(12089 \\
\text { lbs.) } \\
\end{array}$ & $\begin{array}{c}5916 \mathrm{~N} \\
(1330 \text { lbs. })\end{array}$ & $-160 \%$ & $\begin{array}{c}53400 \mathrm{~N} \\
(12005 \\
\text { lbs.) } \\
\end{array}$ & $\begin{array}{l}23709 \mathrm{~N} \\
\text { (5330 lbs.) }\end{array}$ & $-77 \%$ & $\begin{array}{c}56968 \mathrm{~N} \\
(12807 \text { lbs.) }\end{array}$ & $\begin{array}{c}35363 \mathrm{~N} \\
\text { (7950 lbs.) }\end{array}$ & $-47 \%$ \\
\hline & & 800 & - & - & - & - & - & - & - & - & - \\
\hline & & 900 & $\begin{array}{c}64097 \mathrm{~N} \\
(14410 \\
\text { lbs.) }\end{array}$ & $\begin{array}{l}11921 \mathrm{~N} \\
(2680 \text { lbs.) }\end{array}$ & $-137 \%$ & $\begin{array}{c}64400 \mathrm{~N} \\
(14478 \\
\text { lbs.) } \\
\end{array}$ & $\begin{array}{l}28380 \mathrm{~N} \\
(6380 \mathrm{lbs} .)\end{array}$ & $-78 \%$ & - & - & - \\
\hline & \multirow{5}{*}{$\begin{array}{c}\text { Strong } \\
\text { ICEB } \\
\text { Unit } \\
\mathbf{1 1 . 6 4} \\
\text { MPa } \\
\text { (1688 } \\
\text { psi) }\end{array}$} & 500 & - & - & - & $\begin{array}{c}54838 \mathrm{~N} \\
(12328 \\
\text { lbs.) }\end{array}$ & $\begin{array}{c}35897 \mathrm{~N} \\
(8070 \text { lbs.) }\end{array}$ & $-42 \%$ & $\begin{array}{c}55783 \mathrm{~N} \\
(12541 \text { lbs.) }\end{array}$ & $\begin{array}{c}48886 \mathrm{~N} \\
(10990 \\
\text { lbs.) }\end{array}$ & $-13 \%$ \\
\hline & & 600 & $\begin{array}{c}62900 \mathrm{~N} \\
(14140 \\
\text { lbs.) }\end{array}$ & $\begin{array}{c}7073 \mathrm{~N} \\
(1590 \text { lbs.) }\end{array}$ & $-160 \%$ & - & - & - & $\begin{array}{c}61487 \mathrm{~N} \\
(13823 \text { lbs.) }\end{array}$ & $\begin{array}{c}49509 \mathrm{~N} \\
\text { (11130 } \\
\text { lbs.) }\end{array}$ & $-22 \%$ \\
\hline & & 700 & - & - & - & $\begin{array}{c}64209 \mathrm{~N} \\
(14435 \\
\text { lbs.) } \\
\end{array}$ & $\begin{array}{c}47952 \mathrm{~N} \\
(10780 \\
\text { lbs. }) \\
\end{array}$ & $-29 \%$ & $\begin{array}{c}66647 \mathrm{~N} \\
(14983 \text { lbs.) }\end{array}$ & $\begin{array}{c}50354 \mathrm{~N} \\
(11320 \\
\text { lbs.) }\end{array}$ & $-28 \%$ \\
\hline & & 800 & $\begin{array}{l}71591 \mathrm{~N} \\
(16094 \\
\text { lbs.) }\end{array}$ & $\begin{array}{c}7117 \mathrm{~N} \\
(1600 \text { lbs.) }\end{array}$ & $-164 \%$ & - & - & - & - & - & - \\
\hline & & 900 & - & - & - & $\begin{array}{l}73851 \mathrm{~N} \\
\text { (16602 } \\
\text { lbs.) }\end{array}$ & $\begin{array}{l}49153 \mathrm{~N} \\
(11050 \\
\text { lbs.) }\end{array}$ & $-40 \%$ & - & - & - \\
\hline
\end{tabular}


Table 37: Summary of Weak Grout Lap Splice Specimens

\begin{tabular}{|c|c|c|c|c|c|c|}
\hline $\begin{array}{l}\text { Specimen } \\
\text { Name }\end{array}$ & $\begin{array}{c}\text { ICEB Unit Batch } \\
\text { Number }\end{array}$ & $\begin{array}{l}\text { Specimen } \\
\text { Length }\end{array}$ & $\begin{array}{l}\text { Distance } \\
\text { from } \\
\text { Specimen } \\
\text { to LVDT }\end{array}$ & $\begin{array}{l}\text { Distance } \\
\text { from } \\
\text { Specimen } \\
\text { to Top }\end{array}$ & $\begin{array}{l}\text { Max } \\
\text { Load }\end{array}$ & Notes \\
\hline 3WW500 & 8 & $\begin{array}{l}502 \mathrm{~mm} \\
\text { (19.8 in) }\end{array}$ & $\begin{array}{l}125 \mathrm{~mm} \\
(4.9 \mathrm{in})\end{array}$ & $\begin{array}{l}83 \mathrm{~mm} \\
(3.3 \mathrm{in})\end{array}$ & $\begin{array}{l}2131 \mathrm{~N} \\
\text { (0.5 kips) }\end{array}$ & Failure along grout/ICEB unit interface \\
\hline 3WW700 & 4 & $\begin{array}{l}700 \mathrm{~mm} \\
(27.6 \mathrm{in})\end{array}$ & $\begin{array}{l}92 \mathrm{~mm} \\
(3.6 \mathrm{in})\end{array}$ & $\begin{array}{l}86 \mathrm{~mm} \\
(3.4 \mathrm{in})\end{array}$ & $\begin{array}{c}3412 \mathrm{~N} \\
\text { (0.8 kips) }\end{array}$ & Pull out failure. No obvious signs of cracking \\
\hline 3WW900 & 10 & $\begin{array}{l}905 \mathrm{~mm} \\
\text { (35.6 in) }\end{array}$ & $\begin{array}{l}95 \mathrm{~mm} \\
(3.8 \mathrm{in})\end{array}$ & $\begin{array}{l}73 \mathrm{~mm} \\
(2.9 \mathrm{in})\end{array}$ & $\begin{array}{c}3928 \mathrm{~N} \\
(0.9 \mathrm{kips})\end{array}$ & Pull out failure. No obvious signs of cracking \\
\hline 3MW700 & 9 & $\begin{array}{l}700 \mathrm{~mm} \\
\text { (27.6 in) }\end{array}$ & $\begin{array}{l}95 \mathrm{~mm} \\
(3.8 \mathrm{in})\end{array}$ & $\begin{array}{l}95 \mathrm{~mm} \\
(3.8 \mathrm{in})\end{array}$ & $\begin{array}{l}2909 \mathrm{~N} \\
\text { (0.7 kips) }\end{array}$ & Pull out failure. No obvious signs of cracking \\
\hline 3MW900 & 10 & $\begin{array}{l}903 \mathrm{~mm} \\
(35.6 \mathrm{in})\end{array}$ & $\begin{array}{l}86 \mathrm{~mm} \\
(3.4 \mathrm{in})\end{array}$ & $\begin{array}{l}76 \mathrm{~mm} \\
(3.0 \mathrm{in})\end{array}$ & $\begin{array}{c}3790 \mathrm{~N} \\
\text { (0.9 kips) }\end{array}$ & Pull out failure. No obvious signs of cracking \\
\hline 3SW600 & 7 & $\begin{array}{l}606 \mathrm{~mm} \\
\text { (23.9 in) }\end{array}$ & $\begin{array}{l}86 \mathrm{~mm} \\
(3.4 \mathrm{in})\end{array}$ & $\begin{array}{l}86 \mathrm{~mm} \\
(3.4 \mathrm{in})\end{array}$ & $\begin{array}{c}2793 \mathrm{~N} \\
(0.6 \mathrm{kips})\end{array}$ & Pull out failure. No obvious signs of cracking \\
\hline 3SW800 & 9 & $\begin{array}{l}810 \mathrm{~mm} \\
(31.9 \mathrm{in})\end{array}$ & $\begin{array}{l}149 \mathrm{~mm} \\
(5.9 \mathrm{in})\end{array}$ & $\begin{array}{l}78 \mathrm{~mm} \\
(3.1 \mathrm{in})\end{array}$ & $\begin{array}{c}3808 \mathrm{~N} \\
\text { (0.9 kips) }\end{array}$ & Pull out failure. No obvious signs of cracking \\
\hline 4WW600 & 9 & $\begin{array}{l}606 \mathrm{~mm} \\
(23.9 \mathrm{in})\end{array}$ & $\begin{array}{l}102 \mathrm{~mm} \\
(4.0 \mathrm{in})\end{array}$ & $\begin{array}{l}83 \mathrm{~mm} \\
(3.3 \mathrm{in})\end{array}$ & $\begin{array}{c}4386 \mathrm{~N} \\
(1.0 \mathrm{kips})\end{array}$ & Pull out failure. No obvious signs of cracking \\
\hline 4WW800 & 6 & $\begin{array}{l}813 \mathrm{~mm} \\
(32.0 \mathrm{in})\end{array}$ & $\begin{array}{l}83 \mathrm{~mm} \\
(3.3 \mathrm{in})\end{array}$ & $\begin{array}{l}83 \mathrm{~mm} \\
(3.3 \mathrm{in})\end{array}$ & $\begin{array}{l}8954 \mathrm{~N} \\
\text { (2.0 kips) }\end{array}$ & Failure along grout/ICEB unit interface \\
\hline 4WW1000 & 5 & $\begin{array}{l}1003 \mathrm{~mm} \\
\text { (39.5 in) }\end{array}$ & $\begin{array}{l}95 \mathrm{~mm} \\
(3.8 \mathrm{in})\end{array}$ & $\begin{array}{l}84 \mathrm{~mm} \\
(3.3 \mathrm{in})\end{array}$ & $\begin{array}{c}7873 \mathrm{~N} \\
\text { (1.8 kips) }\end{array}$ & Pull out failure. No obvious signs of cracking \\
\hline 4MW700 & 6 & $\begin{array}{l}708 \mathrm{~mm} \\
(27.9 \mathrm{in})\end{array}$ & $\begin{array}{l}95 \mathrm{~mm} \\
(3.8 \mathrm{in})\end{array}$ & $\begin{array}{l}86 \mathrm{~mm} \\
(3.4 \mathrm{in})\end{array}$ & $\begin{array}{c}5916 \mathrm{~N} \\
\text { (1.3 kips) }\end{array}$ & Pull out failure. No obvious signs of cracking \\
\hline 4MW900 & 5 & $\begin{array}{l}902 \mathrm{~mm} \\
(35.5 \mathrm{in})\end{array}$ & $\begin{array}{l}121 \mathrm{~mm} \\
(4.8 \mathrm{in})\end{array}$ & $\begin{array}{l}79 \mathrm{~mm} \\
(3.1 \mathrm{in})\end{array}$ & $\begin{array}{l}11899 \mathrm{~N} \\
\text { (2.7 kips) }\end{array}$ & Pull out failure. No obvious signs of cracking \\
\hline
\end{tabular}




\begin{tabular}{|c|c|c|c|c|c|c|}
\hline $\begin{array}{c}\text { Specimen } \\
\text { Name }\end{array}$ & $\begin{array}{c}\text { ICEB Unit Batch } \\
\text { Number }\end{array}$ & $\begin{array}{c}\text { Specimen } \\
\text { Length }\end{array}$ & $\begin{array}{c}\text { Distance } \\
\text { from } \\
\text { Specimen } \\
\text { to LVDT }\end{array}$ & $\begin{array}{c}\text { Distance } \\
\text { from } \\
\text { Specimen } \\
\text { to Top }\end{array}$ & $\begin{array}{c}\text { Max } \\
\text { Load }\end{array}$ & Notes \\
\hline 4 SW600 & 4 & $\begin{array}{c}651 \mathrm{~mm} \\
(25.6 \mathrm{in})\end{array}$ & $\begin{array}{c}117 \mathrm{~mm} \\
(4.6 \mathrm{in})\end{array}$ & $\begin{array}{c}76 \mathrm{~mm} \\
(3.0 \mathrm{in})\end{array}$ & $\begin{array}{c}7086 \mathrm{~N} \\
(1.6 \mathrm{kips})\end{array}$ & Pull out failure. No obvious signs of cracking \\
\hline 4SW800 & 8 & $\begin{array}{c}813 \mathrm{~mm} \\
(32 \mathrm{in})\end{array}$ & $\begin{array}{c}102 \mathrm{~mm} \\
(4.0 \mathrm{in})\end{array}$ & $\begin{array}{c}83 \mathrm{~mm} \\
(3.3 \mathrm{in})\end{array}$ & $\begin{array}{c}7122 \mathrm{~N} \\
(1.6 \mathrm{kips})\end{array}$ & Pull out failure. No obvious signs of cracking \\
\hline
\end{tabular}




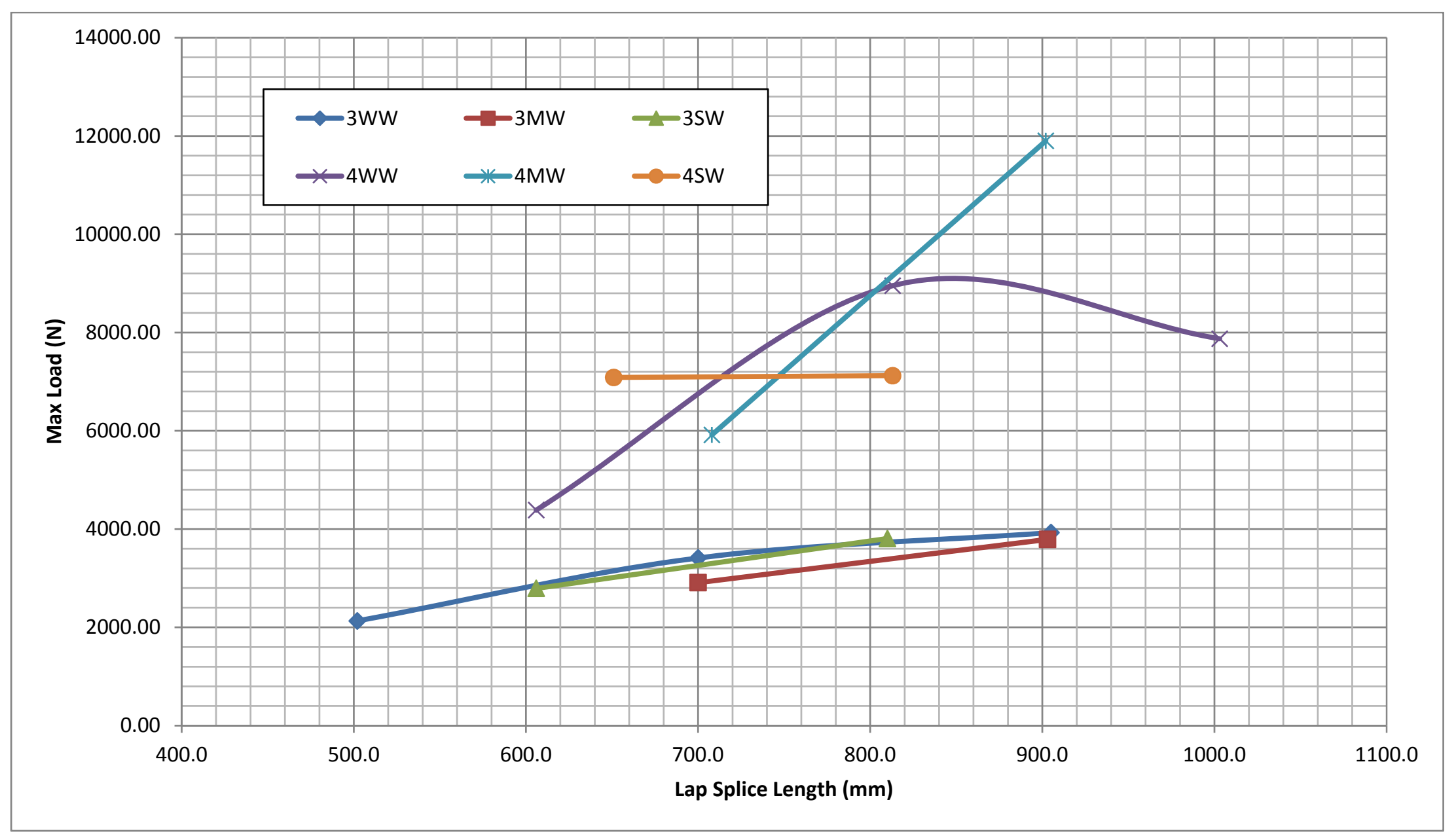

Figure 56: Weak Grout Lap Splice Strength vs. Lap Splice Length 
Table 38: Summary of Medium Grout Lap Splice Specimens

\begin{tabular}{|c|c|c|c|c|c|c|}
\hline $\begin{array}{l}\text { Specimen } \\
\text { Name }\end{array}$ & $\begin{array}{l}\text { ICEB Unit Batch } \\
\text { Number }\end{array}$ & $\begin{array}{l}\text { Specimen } \\
\text { Length }\end{array}$ & $\begin{array}{c}\text { Distance } \\
\text { from } \\
\text { Specimen } \\
\text { to LVDT }\end{array}$ & $\begin{array}{l}\text { Distance } \\
\text { from } \\
\text { Specimen } \\
\text { to Top }\end{array}$ & $\begin{array}{l}\text { Max } \\
\text { Load }\end{array}$ & Notes \\
\hline 3WM500 & 7 & $\begin{array}{l}506 \mathrm{~mm} \\
\text { (19.9 in) }\end{array}$ & $\begin{array}{l}146 \mathrm{~mm} \\
\text { (5.8 in) }\end{array}$ & $\begin{array}{l}198 \mathrm{~mm} \\
(7.8 \mathrm{in})\end{array}$ & $\begin{array}{c}9759 \mathrm{~N} \\
\text { (2.2 kips) }\end{array}$ & Failure along grout/ICEB unit interface \\
\hline 3WM700 & 4 & $\begin{array}{l}710 \mathrm{~mm} \\
(27.9 \mathrm{in})\end{array}$ & $\begin{array}{l}146 \mathrm{~mm} \\
(5.8 \mathrm{in})\end{array}$ & $\begin{array}{c}203 \mathrm{~mm} \\
(8.0 \mathrm{in})\end{array}$ & $\begin{array}{c}14586 \mathrm{~N} \\
\text { (3.3 kips) }\end{array}$ & Failure along grout/ICEB unit interface \\
\hline 3WM900 & 11 & $\begin{array}{l}905 \mathrm{~mm} \\
\text { (35.6 in) }\end{array}$ & $\begin{array}{l}197 \mathrm{~mm} \\
(7.8 \mathrm{in})\end{array}$ & $\begin{array}{l}114 \mathrm{~mm} \\
(4.5 \mathrm{in})\end{array}$ & $\begin{array}{c}16930 \mathrm{~N} \\
\text { (3.8 kips) }\end{array}$ & Failure along grout/ICEB unit interface \\
\hline 3MM500 & 1 & $\begin{array}{l}506 \mathrm{~mm} \\
\text { (19.9 in) }\end{array}$ & $\begin{array}{c}152 \mathrm{~mm}( \\
6.0 \mathrm{in})\end{array}$ & $\begin{array}{c}178 \mathrm{~mm} \\
(7.0 \mathrm{in})\end{array}$ & $\begin{array}{c}18416 \mathrm{~N} \\
\text { (4.1 kips) }\end{array}$ & Failure along grout/ICEB unit interface \\
\hline 3MM700 & 11 & $\begin{array}{l}705 \mathrm{~mm} \\
\text { (27.8 in) }\end{array}$ & $\begin{array}{l}140 \mathrm{~mm} \\
(5.5 \mathrm{in})\end{array}$ & $\begin{array}{l}197 \mathrm{~mm} \\
(7.8 \mathrm{in})\end{array}$ & $\begin{array}{c}22980 \mathrm{~N} \\
\text { (5.2 kips) }\end{array}$ & Failure along grout/ICEB unit interface \\
\hline 3MM800 & 2 & $\begin{array}{l}811 \mathrm{~mm} \\
\text { (31.9 in) }\end{array}$ & $\begin{array}{l}95 \mathrm{~mm} \\
(3.8 \mathrm{in})\end{array}$ & $\begin{array}{l}175 \mathrm{~mm} \\
(6.9 \mathrm{in})\end{array}$ & $\begin{array}{c}18322 \mathrm{~N} \\
\text { (4.1 kips) }\end{array}$ & Failure along grout/ICEB unit interface \\
\hline 3МM900 & 3 & $\begin{array}{l}900 \mathrm{~mm} \\
\text { (35.4 in) }\end{array}$ & $\begin{array}{l}165 \mathrm{~mm} \\
(6.5 \mathrm{in})\end{array}$ & $\begin{array}{l}140 \mathrm{~mm} \\
(5.5 \mathrm{in})\end{array}$ & $\begin{array}{c}18634 \mathrm{~N} \\
\text { (4.2 kips) }\end{array}$ & Pull out failure. No obvious signs of cracking \\
\hline 3SM500 & 5 & $\begin{array}{l}508 \mathrm{~mm} \\
(20.0 \mathrm{in})\end{array}$ & $\begin{array}{l}146 \mathrm{~mm} \\
(5.8 \mathrm{in})\end{array}$ & $\begin{array}{l}173 \mathrm{~mm} \\
(6.8 \mathrm{in})\end{array}$ & $\begin{array}{c}22383 \mathrm{~N} \\
\text { (5.0 kips) }\end{array}$ & Failure along grout/ICEB unit interface \\
\hline 3SM700 & 6 & $\begin{array}{l}705 \mathrm{~mm} \\
\text { (27.8 in) }\end{array}$ & $\begin{array}{l}143 \mathrm{~mm} \\
(5.6 \mathrm{in})\end{array}$ & $\begin{array}{l}191 \mathrm{~mm} \\
(7.5 \mathrm{in})\end{array}$ & $\begin{array}{c}29772 \mathrm{~N} \\
\text { (6.7 kips) }\end{array}$ & Pull out failure. No obvious signs of cracking \\
\hline 4WM600 & 6 & $\begin{array}{l}616 \mathrm{~mm} \\
(24.3 \mathrm{in})\end{array}$ & $\begin{array}{l}105 \mathrm{~mm} \\
(4.1 \mathrm{in})\end{array}$ & $\begin{array}{l}168 \mathrm{~mm} \\
(6.6 \mathrm{in})\end{array}$ & $\begin{array}{c}12299 \mathrm{~N} \\
\text { (2.8 kips) }\end{array}$ & Failure along grout/ICEB unit interface \\
\hline 4WM800 & 8 & $\begin{array}{l}806 \mathrm{~mm} \\
\text { (31.8 in) }\end{array}$ & $\begin{array}{l}98 \mathrm{~mm} \\
(3.9 \mathrm{in})\end{array}$ & $\begin{array}{l}202 \mathrm{~mm} \\
(7.9 \mathrm{in})\end{array}$ & $\begin{array}{c}16556 \mathrm{~N} \\
\text { (3.7 kips) }\end{array}$ & Failure along grout/ICEB unit interface \\
\hline 4WM900 & 3 & $\begin{array}{l}908 \mathrm{~mm} \\
\text { (35.8 in) }\end{array}$ & $\begin{array}{l}108 \mathrm{~mm} \\
(4.3 \mathrm{in})\end{array}$ & $\begin{array}{c}203 \mathrm{~mm} \\
(8.0 \mathrm{in})\end{array}$ & $\begin{array}{l}19212 \mathrm{~N} \\
\text { (4.3 kips) }\end{array}$ & Failure along grout/ICEB unit interface \\
\hline
\end{tabular}




\begin{tabular}{|c|c|c|c|c|c|c|}
\hline $\begin{array}{c}\text { Specimen } \\
\text { Name }\end{array}$ & $\begin{array}{c}\text { ICEB Unit Batch } \\
\text { Number }\end{array}$ & $\begin{array}{c}\text { Specimen } \\
\text { Length }\end{array}$ & $\begin{array}{c}\text { Distance } \\
\text { from } \\
\text { Specimen } \\
\text { to LVDT }\end{array}$ & $\begin{array}{c}\text { Distance } \\
\text { from } \\
\text { Specimen } \\
\text { to Top }\end{array}$ & $\begin{array}{c}\text { Max } \\
\text { Load }\end{array}$ & Notes \\
\hline 4MM500 & 5 & $\begin{array}{c}508 \mathrm{~mm} \\
(20.0 \mathrm{in})\end{array}$ & $\begin{array}{c}86 \mathrm{~mm} \\
(3.4 \mathrm{in})\end{array}$ & $\begin{array}{c}187 \mathrm{~mm} \\
(7.4 \mathrm{in})\end{array}$ & $\begin{array}{c}14243 \mathrm{~N} \\
(3.2 \mathrm{kips})\end{array}$ & Failure along grout/ICEB unit interface \\
\hline 4MM700 & 8 & $\begin{array}{c}699 \mathrm{~mm} \\
(27.5 \mathrm{in})\end{array}$ & $\begin{array}{c}140 \mathrm{~mm} \\
(5.5 \mathrm{in})\end{array}$ & $\begin{array}{c}197 \mathrm{~mm} \\
(7.8 \mathrm{in})\end{array}$ & $\begin{array}{c}23727 \mathrm{~N} \\
(5.3 \mathrm{kips})\end{array}$ & Failure along grout/ICEB unit interface \\
\hline 4MM900 & 7 & $\begin{array}{c}903 \mathrm{~mm} \\
(35.6 \mathrm{in})\end{array}$ & $\begin{array}{c}146 \mathrm{~mm} \\
(5.8 \mathrm{in})\end{array}$ & $\begin{array}{c}159 \mathrm{~mm} \\
(6.3 \mathrm{in})\end{array}$ & $\begin{array}{c}28389 \mathrm{~N} \\
(6.4 \mathrm{kips})\end{array}$ & Failure along grout/ICEB unit interface \\
\hline 4SM500 & 5 & $\begin{array}{c}532 \mathrm{~mm} \\
(20.9 \mathrm{in})\end{array}$ & $\begin{array}{c}162 \mathrm{~mm} \\
(6.4 \mathrm{in})\end{array}$ & $\begin{array}{c}152 \mathrm{~mm} \\
(6.0 \mathrm{in})\end{array}$ & $\begin{array}{c}35884 \mathrm{~N} \\
(8.1 \mathrm{kips})\end{array}$ & Failure along grout/ICEB unit interface \\
\hline 4SM700 & 2 & $\begin{array}{c}705 \mathrm{~mm} \\
(27.8 \mathrm{in})\end{array}$ & $\begin{array}{c}165 \mathrm{~mm} \\
(6.5 \mathrm{in})\end{array}$ & $\begin{array}{c}191 \mathrm{~mm} \\
(7.5 \mathrm{in})\end{array}$ & $\begin{array}{c}47961 \mathrm{~N} \\
(10.8 \mathrm{kips})\end{array}$ & Failure along grout/ICEB unit interface \\
\hline 4SM900 & 1 & $\begin{array}{c}886 \mathrm{~mm} \\
(34.9 \mathrm{in})\end{array}$ & $\begin{array}{c}137 \mathrm{~mm} \\
(5.4 \mathrm{in})\end{array}$ & $\begin{array}{c}165 \mathrm{~mm} \\
(6.5 \mathrm{in})\end{array}$ & $\begin{array}{c}49162 \mathrm{~N} \\
(11.1 \mathrm{kips})\end{array}$ & Failure along grout/ICEB unit interface \\
\hline
\end{tabular}




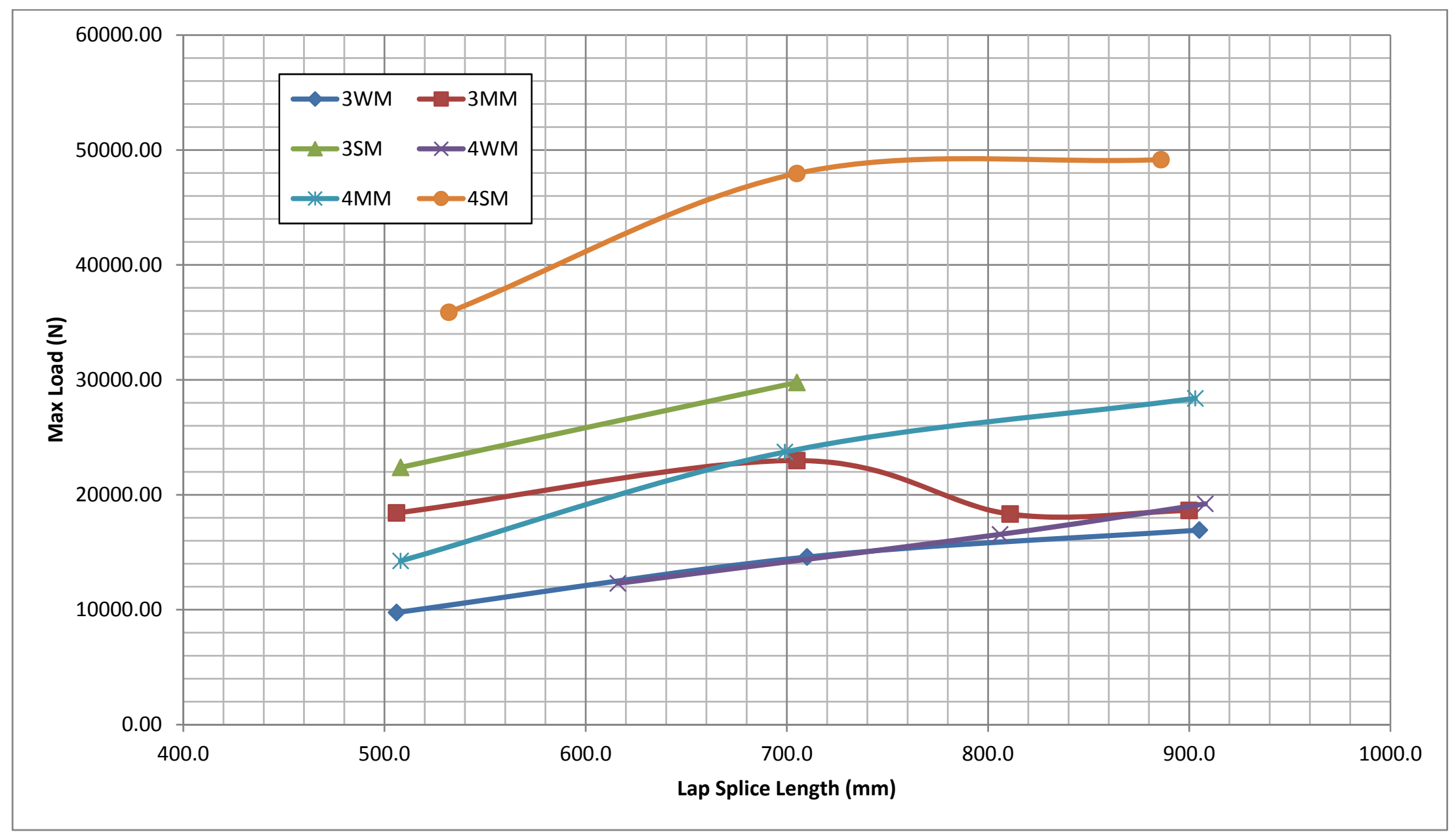

Figure 57: Medium Grout Lap Splice Strength vs. Lap Splice Length 
Table 39: Summary of Strong Grout Lap Splice Specimens

\begin{tabular}{|c|c|c|c|c|c|c|}
\hline $\begin{array}{l}\text { Specimen } \\
\text { Name }\end{array}$ & $\begin{array}{c}\text { ICEB Unit Batch } \\
\text { Number }\end{array}$ & $\begin{array}{l}\text { Specimen } \\
\text { Length }\end{array}$ & \begin{tabular}{|l|}
$\begin{array}{l}\text { Distance } \\
\text { from } \\
\text { Specimen } \\
\text { to LVDT }\end{array}$ \\
\end{tabular} & \begin{tabular}{|c|}
$\begin{array}{c}\text { Distance } \\
\text { from } \\
\text { Specimen } \\
\text { to Top }\end{array}$ \\
\end{tabular} & Max Load & Notes \\
\hline 3WS600 & 1 & $\begin{array}{l}606 \mathrm{~mm} \\
(23.9 \mathrm{in})\end{array}$ & $\begin{array}{l}165 \mathrm{~mm} \\
(6.5 \mathrm{in})\end{array}$ & $\begin{array}{r}95 \mathrm{~mm} \\
(3.8 \mathrm{in}) \\
\end{array}$ & \begin{tabular}{|}
$28691 \mathrm{~N}$ \\
(6.5 kips)
\end{tabular} & Failure along grout/ICEB unit interface \\
\hline 3WS800 & 1 & $\begin{array}{l}847 \mathrm{~mm} \\
\text { (33.3 in) }\end{array}$ & $\begin{array}{l}83 \mathrm{~mm} \\
(3.3 \mathrm{in})\end{array}$ & $\begin{array}{l}102 \mathrm{~mm} \\
(4.0 \mathrm{in})\end{array}$ & $\begin{array}{c}34652 \mathrm{~N} \\
\text { (7.8 kips) }\end{array}$ & Failure along grout/ICEB unit interface \\
\hline 3MS500 & 2 & $\begin{array}{l}505 \mathrm{~mm} \\
(19.9 \mathrm{in})\end{array}$ & $\begin{array}{l}181 \mathrm{~mm} \\
(7.1 \mathrm{in})\end{array}$ & $\begin{array}{l}105 \mathrm{~mm} \\
(4.1 \mathrm{in})\end{array}$ & $\begin{array}{c}26311 \mathrm{~N} \\
\text { (5.9 kips) }\end{array}$ & Failure along grout/ICEB unit interface \\
\hline 3MS700 & 6 & $\begin{array}{l}711 \mathrm{~mm} \\
\text { (28.0 in) }\end{array}$ & $\begin{array}{l}187 \mathrm{~mm} \\
(7.4 \mathrm{in})\end{array}$ & $\begin{array}{l}92 \mathrm{~mm} \\
\text { (3.6 in) }\end{array}$ & $\begin{array}{c}33584 \mathrm{~N} \\
\text { (7.6 kips) }\end{array}$ & Failure along grout/ICEB unit interface \\
\hline $3 S S 400$ & 6 & $\begin{array}{l}405 \mathrm{~mm} \\
(15.9 \mathrm{in})\end{array}$ & $\begin{array}{l}156 \mathrm{~mm} \\
(6.1 \mathrm{in})\end{array}$ & $\begin{array}{l}108 \mathrm{~mm} \\
(4.3 \mathrm{in})\end{array}$ & $\begin{array}{c}41284 \mathrm{~N} \\
(9.3 \mathrm{kips})\end{array}$ & $\begin{array}{l}\text { Failure along grout/ICEB unit interface. Rebar } \\
\text { slipping failure. Had to re tighten bolts. Loading } \\
\text { rate increased to } .08 \text { at } 6.7 \mathrm{k} \text {, then to } .1 \text { at } 9.233 \mathrm{k}\end{array}$ \\
\hline $3 S S 600$ & 2 & $\begin{array}{l}610 \mathrm{~mm} \\
(24.0 \mathrm{in})\end{array}$ & $\begin{array}{l}156 \mathrm{~mm} \\
(6.1 \mathrm{in})\end{array}$ & $\begin{array}{l}98 \mathrm{~mm} \\
(3.9 \mathrm{in})\end{array}$ & $\begin{array}{c}42129 \mathrm{~N} \\
\text { (9.5 kips) }\end{array}$ & Pull out failure. No obvious signs of cracking \\
\hline $3 S S 700$ & 3 & $\begin{array}{l}714 \mathrm{~mm} \\
\text { (28.1 in) }\end{array}$ & $\begin{array}{l}178 \mathrm{~mm} \\
\quad(7 \mathrm{in})\end{array}$ & $\begin{array}{l}95 \mathrm{~mm} \\
(3.8 \mathrm{in})\end{array}$ & $\begin{array}{c}44375 \mathrm{~N} \\
(10.0 \text { kips })\end{array}$ & $\begin{array}{l}\text { Failure along grout/ICEB unit interface. Screws } \\
\text { striped. Retightened and ran test again. }\end{array}$ \\
\hline 4WS600 & 2 & $\begin{array}{l}608 \mathrm{~mm} \\
(23.9 \mathrm{in})\end{array}$ & $\begin{array}{l}171 \mathrm{~mm} \\
(6.8 \mathrm{in})\end{array}$ & $\begin{array}{r}95 \mathrm{~mm} \\
(3.8 \mathrm{in})\end{array}$ & $\begin{array}{r}30154 \mathrm{~N} \\
\text { (6.8 kips) } \\
\end{array}$ & $\begin{array}{l}\text { Failure along grout/ICEB unit interface. Prying } \\
\text { effect }\end{array}$ \\
\hline 4WS800 & 2 & $\begin{array}{l}811 \mathrm{~mm} \\
(31.9 \mathrm{in})\end{array}$ & $\begin{array}{l}197 \mathrm{~mm} \\
(7.8 \mathrm{in})\end{array}$ & $\begin{array}{l}76 \mathrm{~mm} \\
(3.0 \mathrm{in})\end{array}$ & \begin{tabular}{|c|}
$34540 \mathrm{~N}$ \\
(7.8 kips) \\
\end{tabular} & Failure along grout/ICEB unit interface \\
\hline 4MS500 & 3 & $\begin{array}{l}511 \mathrm{~mm} \\
(20.1 \mathrm{in})\end{array}$ & $\begin{array}{l}167 \mathrm{~mm} \\
(6.6 \mathrm{in})\end{array}$ & $\begin{array}{l}114 \mathrm{~mm} \\
(4.5 \mathrm{in})\end{array}$ & $\begin{array}{c}32952 \mathrm{~N} \\
\text { (7.4 kips) }\end{array}$ & Failure along grout/ICEB unit interface \\
\hline 4MS700 & 4 & $\begin{array}{l}705 \mathrm{~mm} \\
(27.8 \mathrm{in})\end{array}$ & $\begin{array}{l}194 \mathrm{~mm} \\
(7.6 \mathrm{in})\end{array}$ & $\begin{array}{l}83 \mathrm{~mm} \\
(3.3 \mathrm{in})\end{array}$ & \begin{tabular}{|}
$35363 \mathrm{~N}$ \\
$(8.0 \mathrm{kips})$ \\
\end{tabular} & Failure along back face \\
\hline 4SS500 & 4 & $\begin{array}{l}502 \mathrm{~mm} \\
(19.8 \mathrm{in})\end{array}$ & $\begin{array}{l}162 \mathrm{~mm} \\
(6.4 \mathrm{in})\end{array}$ & $\begin{array}{l}121 \mathrm{~mm} \\
(4.8 \mathrm{in})\end{array}$ & $\begin{array}{c}48904 \mathrm{~N} \\
(11.0 \mathrm{kips})\end{array}$ & $\begin{array}{l}\text { Failure along grout/ICEB unit interface. Prying } \\
\text { effect }\end{array}$ \\
\hline
\end{tabular}




\begin{tabular}{|c|c|c|c|c|c|c|}
\hline $\begin{array}{c}\text { Specimen } \\
\text { Name }\end{array}$ & $\begin{array}{c}\text { ICEB Unit Batch } \\
\text { Number }\end{array}$ & $\begin{array}{c}\text { Specimen } \\
\text { Length }\end{array}$ & $\begin{array}{c}\text { Distance } \\
\text { from } \\
\text { Specimen } \\
\text { to LVDT }\end{array}$ & $\begin{array}{c}\text { Distance } \\
\text { from } \\
\text { Specimen } \\
\text { to Top }\end{array}$ & Max Load & Notes \\
\hline 4 SS600 & 7 & $\begin{array}{c}610 \mathrm{~mm} \\
(24.0 \mathrm{in})\end{array}$ & $\begin{array}{c}149 \mathrm{~mm} \\
(5.9 \mathrm{in})\end{array}$ & $\begin{array}{c}100 \mathrm{~mm} \\
(3.9 \mathrm{in})\end{array}$ & $\begin{array}{c}49495 \mathrm{~N} \\
(11.1 \mathrm{kips})\end{array}$ & Failure along grout/ICEB unit interface \\
\hline $4 \mathrm{SS700}$ & 5 & $\begin{array}{c}705 \mathrm{~mm} \\
(27.8 \mathrm{in})\end{array}$ & $\begin{array}{l}156 \mathrm{~mm} \\
(6.1 \mathrm{in})\end{array}$ & $\begin{array}{c}108 \mathrm{~mm} \\
(4.3 \mathrm{in})\end{array}$ & $\begin{array}{c}50372 \mathrm{~N} \\
(11.3 \mathrm{kips})\end{array}$ & Failure along grout/ICEB unit interface \\
\hline
\end{tabular}




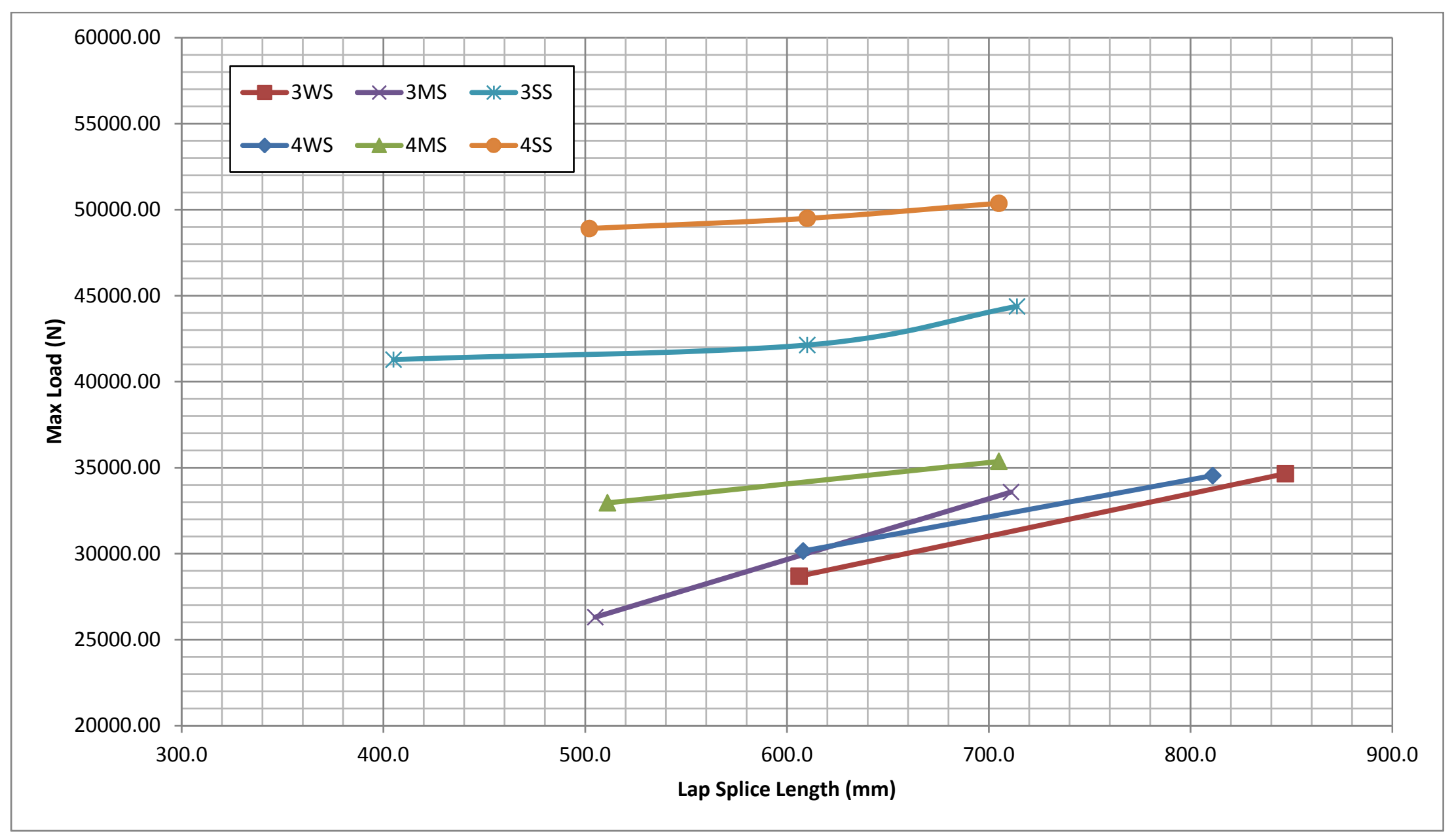

Figure 58: Strong Grout Lap Splice Strength vs. Lap Splice Length 
APPENDIX C: GROUT SPECIMEN DATA SUMMARY

Table 40: Summary of Weak Grout Dimensions and Compressive Strength

\begin{tabular}{|c|c|c|c|c|c|c|}
\hline $\begin{array}{l}\text { Specimen } \\
\text { Name }\end{array}$ & $\begin{array}{c}\text { Cast in ICEB } \\
\text { unit or } \\
\text { cylinder? } \\
\end{array}$ & $\begin{array}{l}\text { Height } \\
\text { (h) }\end{array}$ & \begin{tabular}{|c|} 
Measured \\
Diameter \\
$1\left(D_{1}\right)$ \\
\end{tabular} & $\begin{array}{c}\text { Measured } \\
\text { Diameter } \\
2\left(D_{2}\right) \\
\end{array}$ & $\begin{array}{c}\text { Average } \\
\text { Diameter } \\
\left(\mathbf{D}_{\mathrm{AVG}}\right) \\
\end{array}$ & $\begin{array}{l}\text { Recorded Maximum } \\
\text { Compressive } \\
\text { Strength }\left(f_{g}^{\prime} \text { or } f_{p g}^{\prime}\right) \\
\end{array}$ \\
\hline $1 \mathrm{WW}$ & $\begin{array}{c}\text { Weak ICEB } \\
\text { unit }\end{array}$ & 4.25 in & 1.52 in & 1.52 in & 1.52 in & 258 psi \\
\hline $2 \mathrm{WW}$ & $\begin{array}{c}\text { Weak ICEB } \\
\text { unit }\end{array}$ & 3.75 in & 1.66 in & $1.63 \mathrm{in}$ & 1.64 in & $195 \mathrm{psi}$ \\
\hline $1 \mathrm{MW}$ & $\begin{array}{c}\text { Medium ICEB } \\
\text { unit }\end{array}$ & 3.88 in & 1.67 in & $1.61 \mathrm{in}$ & 1.64 in & $171 \mathrm{psi}$ \\
\hline 2MW & $\begin{array}{c}\text { Medium ICEB } \\
\text { unit }\end{array}$ & 3.88 in & 1.58 in & 1.65 in & $1.61 \mathrm{in}$ & $212 \mathrm{psi}$ \\
\hline $1 \mathrm{SW}$ & $\begin{array}{c}\text { Strong ICEB } \\
\text { unit }\end{array}$ & 3.88 in & 1.70 in & 1.43 in & 1.57 in & $157 \mathrm{psi}$ \\
\hline 2SW & $\begin{array}{c}\text { Strong ICEB } \\
\text { unit }\end{array}$ & 4.00 in & $1.60 \mathrm{in}$ & $1.63 \mathrm{in}$ & $1.61 \mathrm{in}$ & $178 \mathrm{psi}$ \\
\hline 1W2 & Cylinder & 3.88 in & 2.00 in & 2.00 in & 2.00 in & 69 psi \\
\hline $2 \mathrm{~W} 1$ & Cylinder & 3.94 in & 2.00 in & 2.00 in & 2.00 in & $61 \mathrm{psi}$ \\
\hline $2 \mathrm{~W} 2$ & Cylinder & 4.00 in & 2.00 in & 2.00 in & 2.00 in & 57 psi \\
\hline 3W1 & Cylinder & 3.88 in & 2.00 in & 2.00 in & 2.00 in & 65 psi \\
\hline $3 W 2$ & Cylinder & 4.13 in & 2.00 in & 2.00 in & 2.00 in & $58 \mathrm{psi}$ \\
\hline
\end{tabular}


Table 41: Summary of Medium Grout Dimensions and Compressive Strength

\begin{tabular}{|c|c|c|c|c|c|c|}
\hline $\begin{array}{l}\text { Specimen } \\
\text { Name }\end{array}$ & $\begin{array}{c}\text { Cast in ICEB } \\
\text { unit or } \\
\text { cylinder? }\end{array}$ & Height (h) & $\begin{array}{c}\text { Measured } \\
\text { Diameter } \\
1\left(D_{1}\right)\end{array}$ & $\begin{array}{c}\text { Measured } \\
\text { Diameter } \\
2\left(D_{2}\right)\end{array}$ & $\begin{array}{c}\text { Average } \\
\text { Diameter } \\
\left(\mathbf{D}_{\mathrm{AVG}}\right)\end{array}$ & $\begin{array}{c}\text { Recorded Maximum } \\
\text { Compressive } \\
\text { Strength } \\
\left(\boldsymbol{f}_{\boldsymbol{g}}^{\prime} \text { or } \boldsymbol{f}_{\boldsymbol{p} g}^{\prime}\right)\end{array}$ \\
\hline $1 \mathrm{WM}$ & Weak ICEB unit & 4.50 in & 1.59 in & $1.6 \mathrm{in}$ & 1.59 in & 813 psi \\
\hline 2WM & Weak ICEB unit & 4.38 in & $1.47 \mathrm{in}$ & $1.47 \mathrm{in}$ & 1.47 in & 1041 psi \\
\hline $1 \mathrm{MM}$ & $\begin{array}{c}\text { Medium ICEB } \\
\text { unit } \\
\end{array}$ & 4.00 in & 1.65 in & $1.61 \mathrm{in}$ & $1.63 \mathrm{in}$ & 1409 psi \\
\hline $2 \mathrm{MM}$ & $\begin{array}{c}\text { Medium ICEB } \\
\text { unit } \\
\end{array}$ & 4.25 in & 1.49 in & 1.54 in & $1.52 \mathrm{in}$ & 1082 psi \\
\hline $1 \mathrm{SM}$ & $\begin{array}{c}\text { Strong ICEB } \\
\text { unit } \\
\end{array}$ & 4.13 in & 1.58 in & 1.58 in & $1.58 \mathrm{in}$ & 1206 psi \\
\hline 2SM & $\begin{array}{c}\text { Strong ICEB } \\
\text { unit } \\
\end{array}$ & $4.00 \mathrm{in}$ & 1.35 in & $1.60 \mathrm{in}$ & $1.47 \mathrm{in}$ & 950 psi \\
\hline 1M1 & Cylinder & 3.63 in & 1.99 in & 2.00 in & 2.00 in & 411 psi \\
\hline $1 \mathrm{M} 2$ & Cylinder & 3.75 in & 2.00 in & 2.00 in & 2.00 in & $486 \mathrm{psi}$ \\
\hline $2 \mathrm{M3}$ & Cylinder & 3.94 in & 1.99 in & 2.00 in & 1.99 in & 497 psi \\
\hline 2M4 & Cylinder & 4.00 in & 2.00 in & 2.00 in & 2.00 in & 416 psi \\
\hline $3 \mathrm{M} 5$ & Cylinder & 3.75 in & 1.99 in & 2.00 in & 2.00 in & 516 psi \\
\hline $3 \mathrm{M} 6$ & Cylinder & 4.13 in & 1.99 in & 2.00 in & 1.99 in & $530 \mathrm{psi}$ \\
\hline
\end{tabular}

Table 42: Summary of Strong Grout Dimensions and Compressive Strength

\begin{tabular}{|c|c|c|c|c|c|c|}
\hline $\begin{array}{l}\text { Specimen } \\
\text { Name }\end{array}$ & $\begin{array}{l}\text { Cast in ICEB or } \\
\text { cylinder? }\end{array}$ & $\begin{array}{l}\text { Height } \\
\text { (h) }\end{array}$ & $\begin{array}{c}\text { Measured } \\
\text { Diameter } \\
1\left(\mathrm{D}_{1}\right) \\
\end{array}$ & $\begin{array}{c}\text { Measured } \\
\text { Diameter } \\
2\left(\mathrm{D}_{2}\right) \\
\end{array}$ & $\begin{array}{l}\text { Average } \\
\text { Diameter } \\
\text { (DAVG) } \\
\end{array}$ & $\begin{array}{l}\text { Recorded Maximum } \\
\text { Compressive Strength } \\
\left(f_{g}^{\prime} \text { or } f_{p g}^{\prime}\right)\end{array}$ \\
\hline $1 \mathrm{WS}$ & Weak ICEB unit & 4.18 in & $1.68 \mathrm{in}$ & 1.66 in & 1.67 in & 2496 psi \\
\hline $2 \mathrm{WS}$ & Weak ICEB unit & 4.27 in & 1.59 in & 1.60 in & 1.60 in & 1912 psi \\
\hline 1MS & $\begin{array}{c}\text { Medium ICEB } \\
\text { unit } \\
\end{array}$ & 4.26 in & 1.64 in & $1.68 \mathrm{in}$ & $1.68 \mathrm{in}$ & 2461 psi \\
\hline 2MS & $\begin{array}{c}\text { Medium ICEB } \\
\text { unit } \\
\end{array}$ & 4.05 in & 1.66 in & $1.63 \mathrm{in}$ & $1.65 \mathrm{in}$ & 1859 psi \\
\hline $1 \mathrm{SS}$ & Strong ICEB unit & 4.04 in & $1.67 \mathrm{in}$ & 1.68 in & 1.68 in & 1920 psi \\
\hline 2SS & Strong ICEB unit & 4.13 in & 1.68 in & 1.69 in & 1.69 in & 2843 psi \\
\hline 1S1 & Cylinder & 3.87 in & 2.00 in & 2.00 in & 2.00 in & 1945 psi \\
\hline $1 \mathrm{~S} 2$ & Cylinder & 3.71 in & 1.99 in & 1.99 in & 1.99 in & 2287 psi \\
\hline 2S3 & Cylinder & 3.70 in & 2.00 in & 2.00 in & 2.00 in & 2220 psi \\
\hline 2S4 & Cylinder & 3.86 in & 2.00 in & 2.00 in & 2.00 in & 1547 psi \\
\hline $3 S 5$ & Cylinder & 3.66 in & 2.00 in & 2.00 in & 2.00 in & 2178 psi \\
\hline $3 \mathrm{~S} 6$ & Cylinder & 3.79 in & 2.00 in & 1.99 in & 1.995 & 1900 psi \\
\hline
\end{tabular}


Table 43: ICEB Prism Strength $\left(\boldsymbol{f}_{m}^{\prime}\right)$ vs. ICEB Unit Batch Strength

\begin{tabular}{|c|c|c|c|c|}
\hline $\begin{array}{c}\text { Prism } \\
\text { Specimen }\end{array}$ & $\begin{array}{c}\text { ICEB Unit } \\
\text { Strength } \\
\text { Type } \\
\end{array}$ & $\begin{array}{l}\text { ICEB Unit Batch } \\
\text { Number }\end{array}$ & $\begin{array}{c}\text { ICEB Unit Batch } \\
\text { Strength (MPa) }\end{array}$ & $\begin{array}{c}\text { Prism } \\
\text { Strength } \\
\text { (MPa) }\end{array}$ \\
\hline WW1 & $\mathrm{W}$ & 5 & 4.20 & 1.65 \\
\hline WW2 & $\mathrm{W}$ & 10 & 4.67 & 1.44 \\
\hline WW3 & W & 9 & 3.79 & 0.94 \\
\hline WM1 & $\mathrm{W}$ & 9 & 3.79 & 1.34 \\
\hline WM2 & $\mathrm{W}$ & 7 & 2.74 & 1.05 \\
\hline WM3 & $\mathrm{W}$ & 3 & 4.36 & 1.53 \\
\hline WS1 & $\mathrm{W}$ & 9 & 3.79 & 1.28 \\
\hline WS2 & W & 7 & 2.74 & 1.11 \\
\hline WS3 & $\mathrm{W}$ & 3 & 4.36 & 1.49 \\
\hline MW1 & $M$ & 11 & 7.34 & 3.54 \\
\hline MW2 & $\mathrm{M}$ & 8 & 7.53 & 2.62 \\
\hline MW3 & $\mathrm{M}$ & 4 & 7.70 & 2.46 \\
\hline MM1 & $M$ & 11 & 7.34 & 3.39 \\
\hline MM2 & $\mathrm{M}$ & 8 & 7.53 & 2.77 \\
\hline MM3 & $\mathrm{M}$ & 7 & 7.51 & 2.56 \\
\hline MS1 & $\mathrm{M}$ & 4 & 7.70 & 3.64 \\
\hline MS2 & $M$ & 1 & 9.72 & 3.06 \\
\hline MS3 & $\mathrm{M}$ & 1 & 9.72 & 3.99 \\
\hline SW1 & $S$ & 9 & 13.46 & 6.56 \\
\hline SW2 & $S$ & 8 & 10.32 & 4.97 \\
\hline SW3 & $S$ & 6 & 11.51 & 5.82 \\
\hline SM1 & $S$ & 8 & 10.32 & 5.11 \\
\hline SM2 & $S$ & 7 & 11.42 & 5.81 \\
\hline SM3 & $S$ & 4 & 11.84 & 5.06 \\
\hline SS1 & $S$ & 1 & 12.02 & 7.03 \\
\hline SS2 & $S$ & 5 & 12.51 & 4.83 \\
\hline SS3 & $S$ & 3 & 10.08 & 6.14 \\
\hline
\end{tabular}

